Felipe Bruno Dias de Oliveira

\title{
CAPACIDADE REGENERATIVA DE CÉLULAS MESENQUIMAIS ADMINISTRADAS DE FORMA LOCAL E SISTÊMICA EM MODELO ANIMAL DE OSTEOARTROSE
}

Tese apresentada à Faculdade Israelita de Ciências da Saúde Albert Einstein para obtenção do Título de Doutor em Ciências da Saúde. 
Felipe Bruno Dias de Oliveira

\section{CAPACIDADE REGENERATIVA DE CÉLULAS MESENQUIMAIS ADMINISTRADAS DE FORMA LOCAL E SISTÊMICA EM MODELO ANIMAL DE OSTEOARTROSE}

Tese apresentada à Faculdade Israelita de Ciências da Saúde Albert Einstein, para obtenção do Título de Doutor em Ciências da Saúde.

Orientador: Prof. Dr. Mario Ferretti Filho Coorientadora: Profa. Dra. Eliana Antoniolli

São Paulo 
O48c

Oliveira, Felipe Bruno Dias de

Capacidade regenerativa de células mesenquimais administradas de forma local e sistêmica em modelo animal de osteoartrose / Felipe Bruno Dias de Oliveira. -- São Paulo, 2020.

$\mathrm{xx}, 168 \mathrm{f}$.

Tese (Doutorado) - Faculdade Israelita de Ciências da Saúde Albert Einstein. Instituto Israelita de Ensino e Pesquisa Albert Einstein.

Programa de Pós-Graduação em Ciências da Saúde.

Título em inglês: Regenerative capacity of systemically and locally administered mesenchymal cells in an animal model of osteoarthritis.

1. Osteoartrite/terapia. 2. Osteoartrite/cirurgia. 3. Transplante de células-tronco mesenquimais. 4. Ratos Wistar.

NLM - WE 348

Elaborada pelo Sistema Einstein Integrado de Bibliotecas 
FACULDADE ISRAELITA DE CIÊNCIAS DA SAÚDE ALBERT EINSTEIN

Coordenador do Curso de Pós-Graduação: Prof. Dr. Luiz Vicente Rizzo 
Felipe Bruno Dias de Oliveira

\section{CAPACIDADE REGENERATIVA DE CÉLULAS MESENQUIMAIS ADMINISTRADAS DE FORMA LOCAL E SISTÊMICA EM MODELO ANIMAL DE OSTEOARTROSE}

Presidente da banca: Prof. Dr. Mario Ferretti Filho

BANCA EXAMINADORA

Membros titulares:

Profa. Dra. Erika Bevilaqua Rangel

Dr. Alessandro Rozim Zorzi

Prof. Dr. Rodrigo Pereira Guimarães

Membros suplentes:

Profa. Dra. Luciana Cavalheiro Marti

Prof. Dr. Luciano Miller Reis Rodrigues

Prof. Dr. Mario Lenza

Aprovada em 17/08/2020. 


\section{Dedicatória}

Dedico este trabalho a meu pai, Helder Carlos Dias de Oliveira, minha mãe, Eliana Maria Soares, e minha avó, Terezinha Gotardo Soares, meus maiores incentivadores.

Independente de qualquer virtude ou força de vontade, tenho a plena

convicção de que, sem o apoio e amor incondicional de vocês, eu jamais teria chegado até aqui!

Muito obrigado, amo vocês! 


\section{Agradecimentos}

Agradeço a FAPESP pelo apoio financeiro, para realização deste estudo (Processo- 2015/16606-0; Processo - 2015/1444-3; Processo - 2018/23457-0).

Agradeço ao meu orientador, Prof. Dr. Mario Ferretti, por ter me aceito como aluno e confiado em meu trabalho.

Agradeço a minha coorientadora, Profa. Dra. Eliane Antonioli, por todo suporte e direcionamento, durante o projeto.

Agradeço a aluna, Olivia Furiama Metropolo Dias, por toda dedicação e comprometimento, durante todo o projeto, especialmente em momentos críticos, os quais foram superados, devido sua atuação.

Agradeço ao Dr. Jean Gabriel de Souza, pela incansável colaboração, conhecimento compartilhado e esforços direcionados em diferentes etapas e experimentos deste projeto.

Agradeço aos membros do Grupo Locomotor, por todas as discussões e compartilhamento de ideias.

Agradeço, por intermédio de Laudiceia Almeida, a todo corpo docente da Pós-graduação Stricto Sensu em Ciências da Saúde, pelo empenho em produzir e transmitir conhecimento.

Agradeço, por intermédio da Dra. Luciana Cintra, a todos os profissionais do Centro de Experimentação e Treinamento em Cirurgia, auxiliadores, durante o desenvolvimento do modelo experimental.

Agradeço, por intermédio do Prof. Dr. Luiz Vicente Rizzo, a todos os profissionais do Instituto Israelita de Ensino e Pesquisa Albert Einstein, que estiveram presentes, no decorrer de meu doutorado e possibilitaram o desenvolvimento deste projeto.

Agradeço, por intermédio da Dra. Ana Marisa Chudzinski-Tavassi, a todos os profissionais do Centre of Excellence in New Target Discovery - Instituto Butantan, que possibilitaram a aquisição das imagens dos experimentos - in vivo e ex vivo.

Agradeço a Dra. Tonia Vincent, por ter me aceito como aluno e me orientado, durante o período de estágio e pesquisa no exterior. 
Agradeço ao Dr. Hayat Muhammad, por todo conhecimento transmitido no decorrer do desenvolvimento do meu projeto de pesquisa no exterior.

Por fim, agradeço a todas as pessoas, que, de alguma forma, contribuíram para a concretização deste trabalho. 
"But your achievement for others may easily come to be inscribed in the book of eternity -- either that which is seen on earth or that other which is believed to be in heaven. For that which you receive from others is a testimony to their virtue, but all that you do for others is the sign and clear indication of your own virtue. Farewell"

Giordano Bruno (On the Infinite Universe and Worlds, 1584.) 


\section{Sumário}

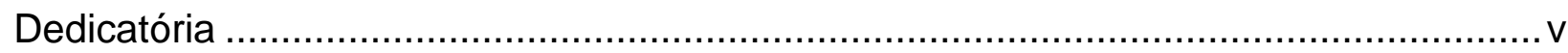

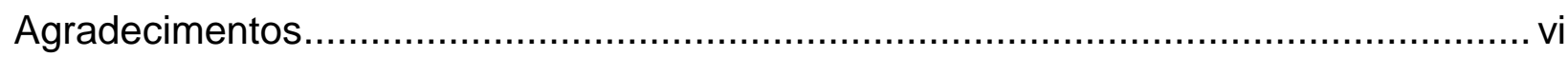

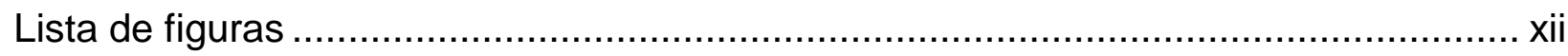

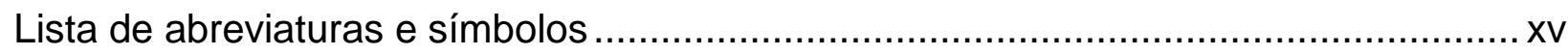

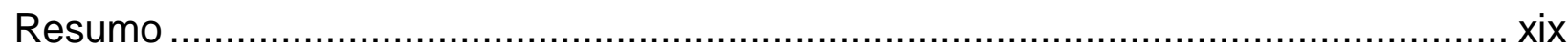

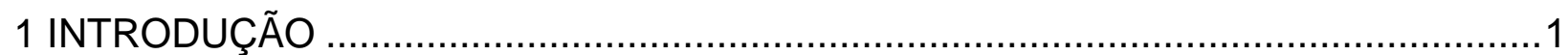

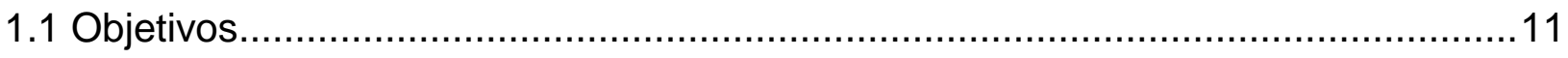

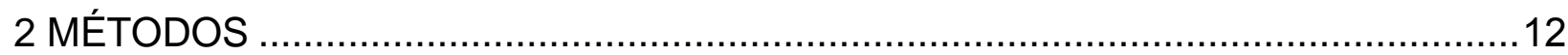

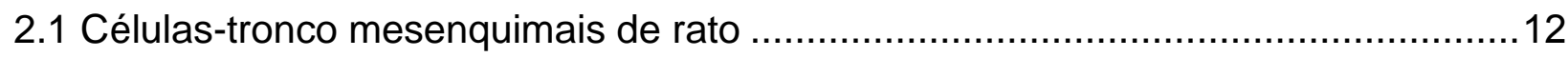

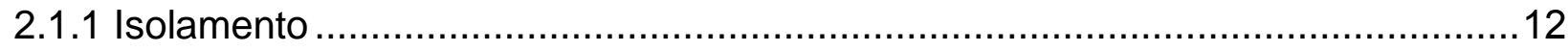

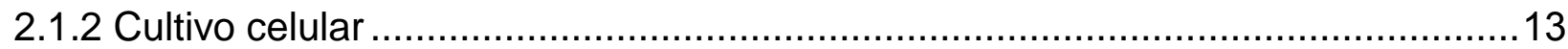

2.1.3 Transdução viral .................................................................................. 14

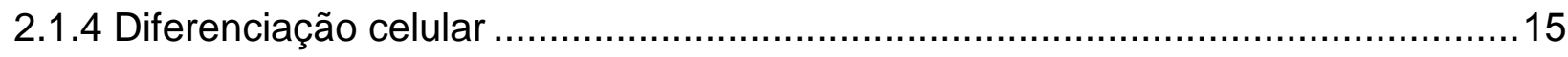

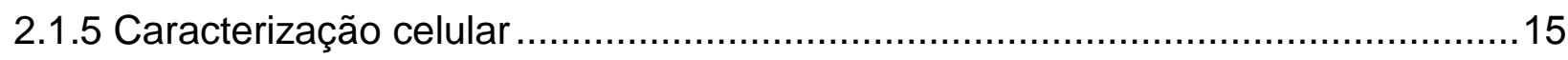

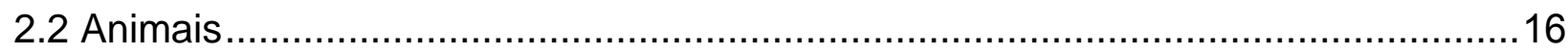

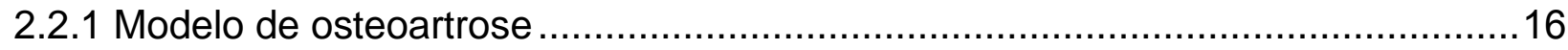

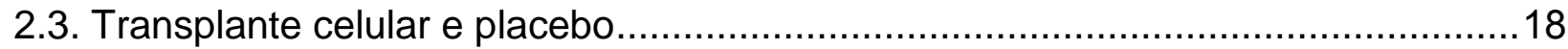

2.3.1 Transplante intravenoso ......................................................................... 19

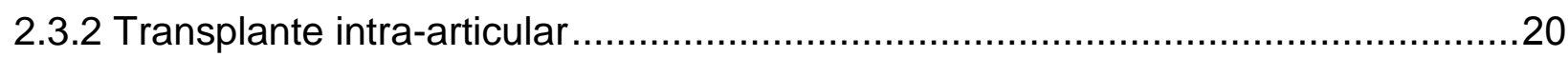

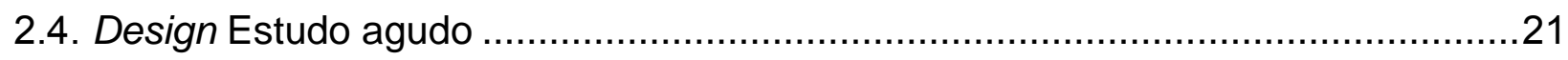

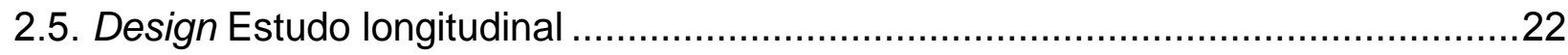

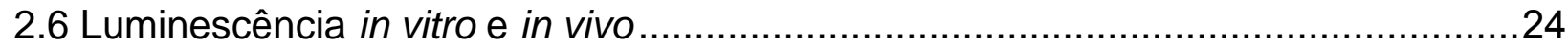

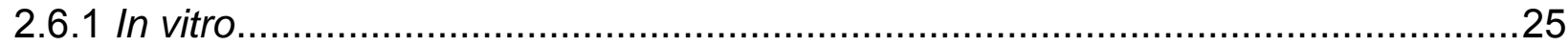

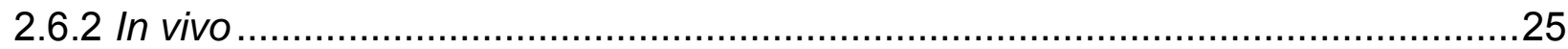

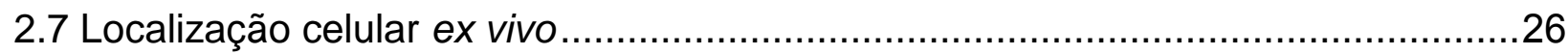

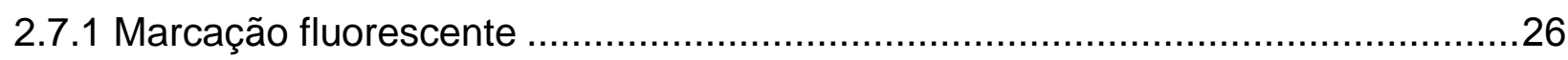

2.7.2 Isolamento e processamento tecidual .................................................26

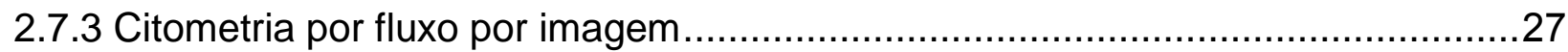

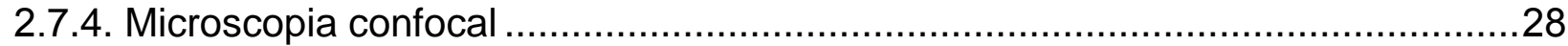

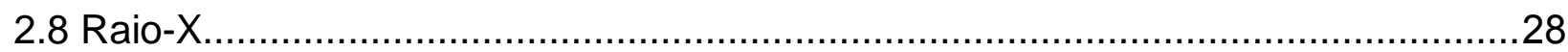

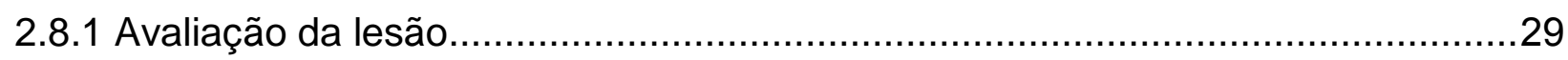




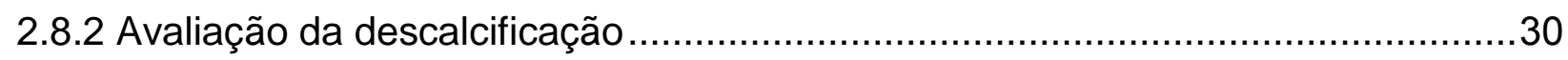

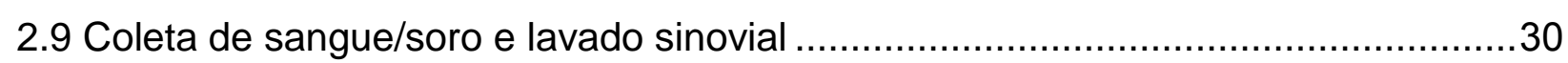

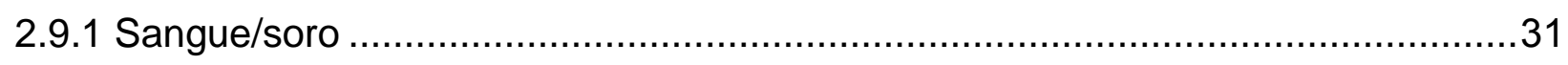

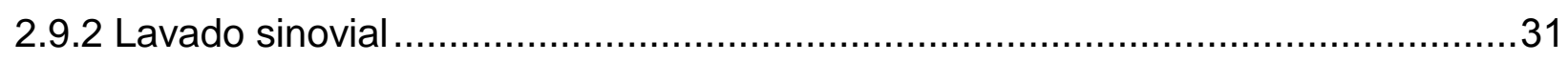

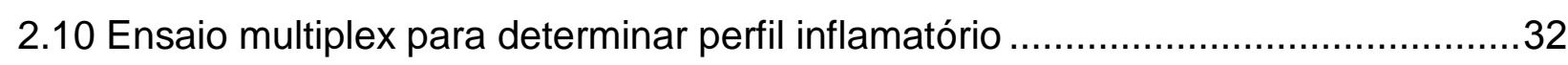

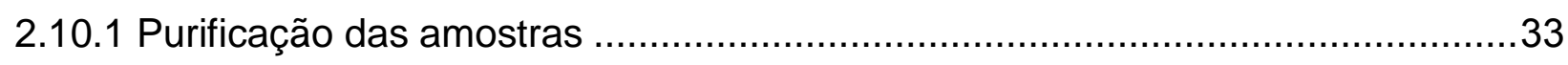

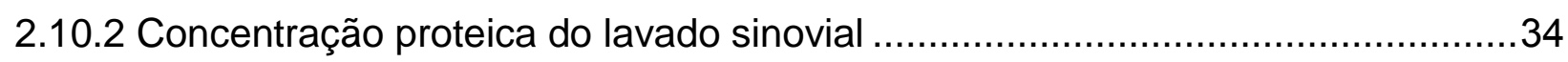

2.11 Processamento e avaliação do material histológico .............................................. 34

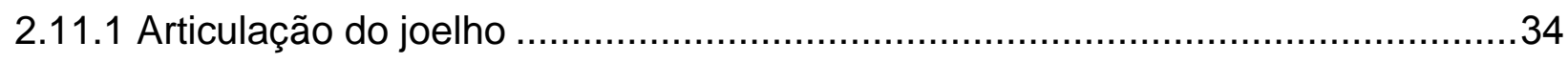

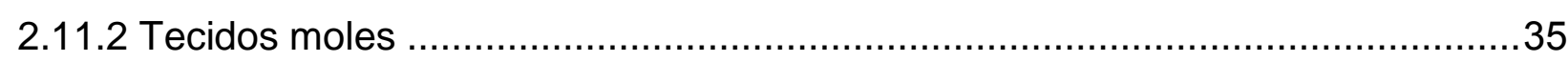

2.11.3 Análise semiquantitativa da cartilagem e membrana sinovial............................36

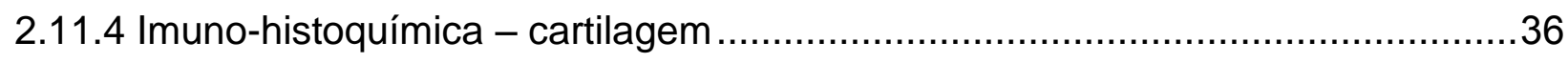

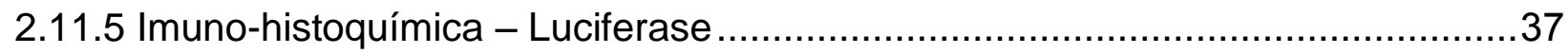

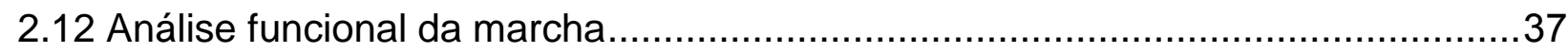

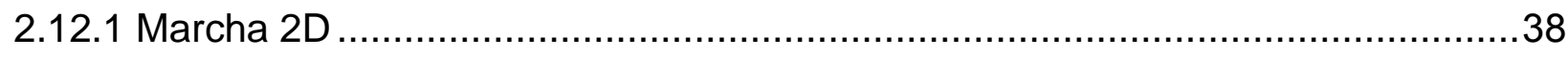

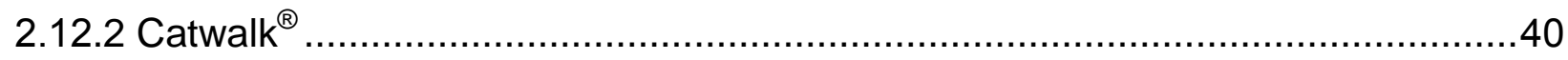

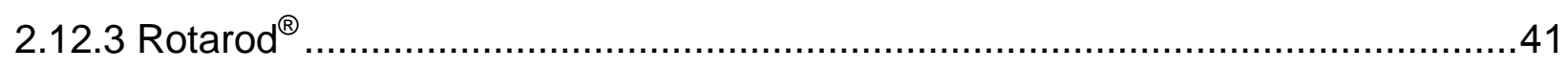

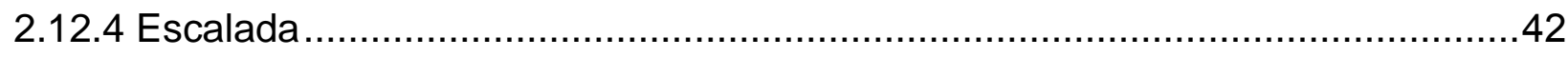

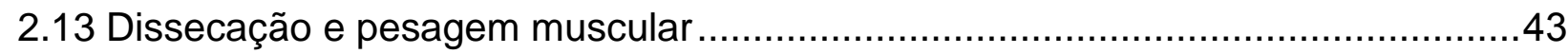

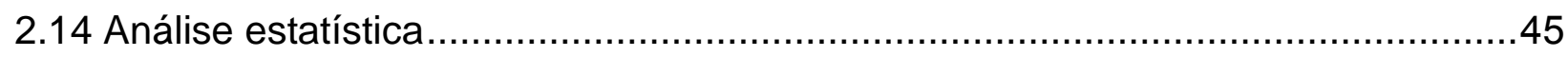

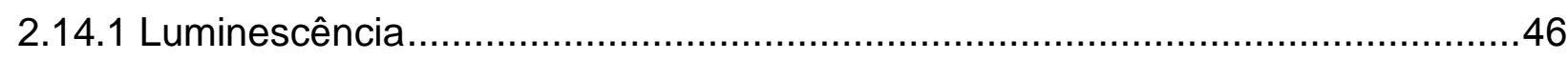

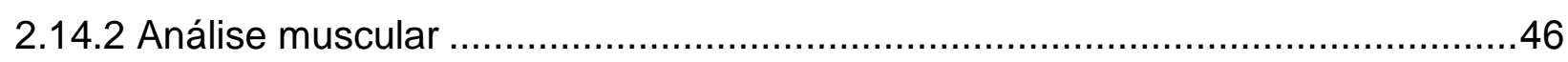

2.14.3 Frequência, amplitude passada, Catwak $^{\circledR}, \operatorname{Rotarod}^{\circledR}$ e Escalada ......................46

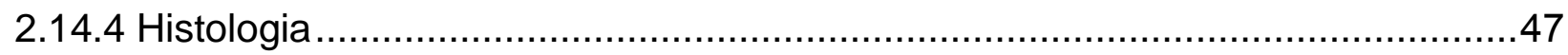

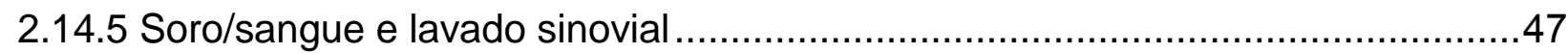

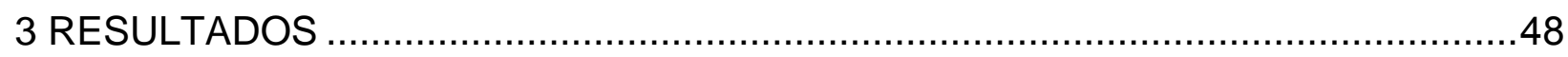

3.1 Obtenção de células-tronco mesenquimais de rato............................................48

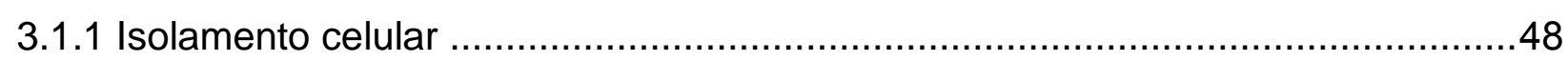

3.1.2 Diferenciação em linhagens mesenquimais ..................................................49

3.1.3 Caracterização por marcadores de superfície ..............................................50

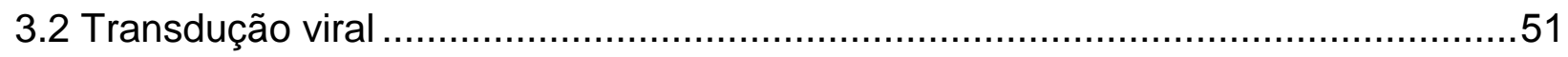

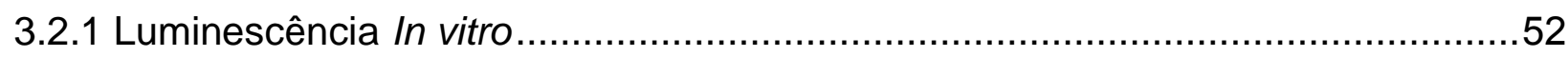

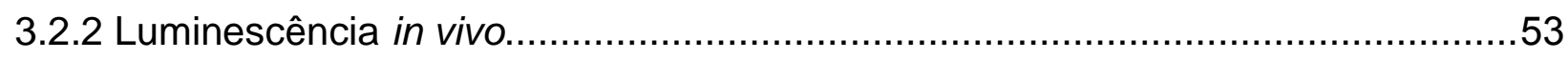




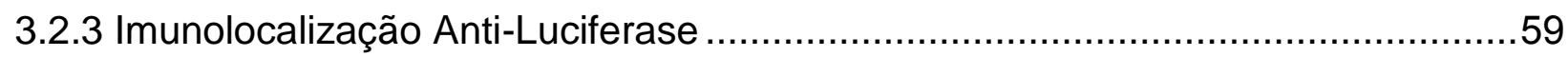

3.3 Citometria de fluxo por imagem e microscopia confocal......................................60

3.4 Análise morfológica e funcional do modelo animal de osteoartrose gerado por cirurgia de desestabilização do menisco medial.......................................................68

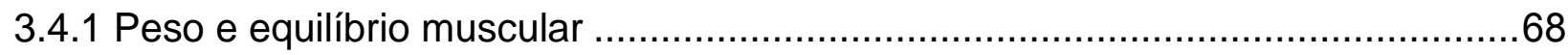

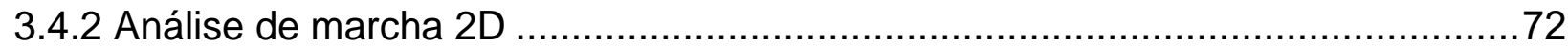

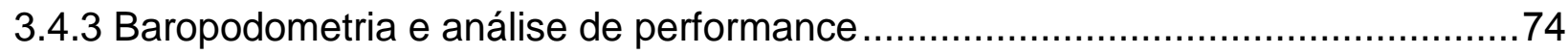

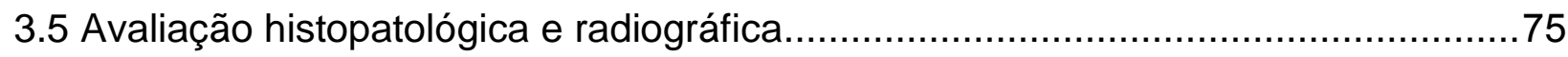

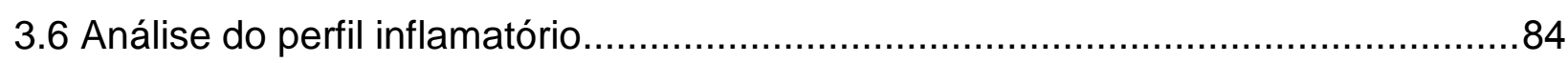

3.6.1 Sangue/soromodelo animal de desestabilização do menisco medial ....................84

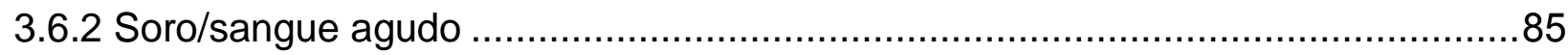

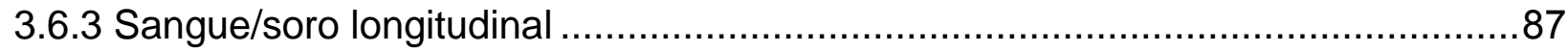

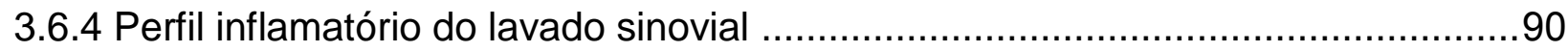

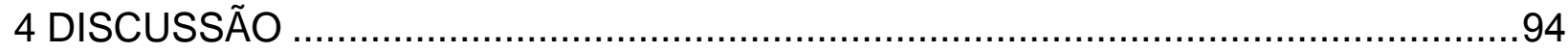

4.1 Análise funcional, morfológica e sorológica do modelo animal..............................94

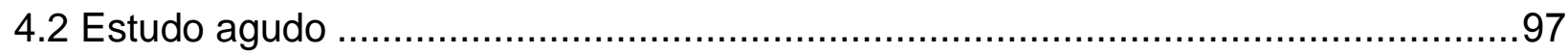

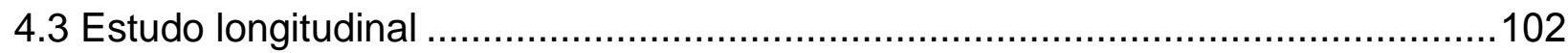

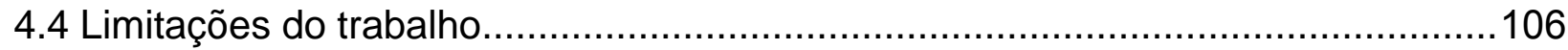

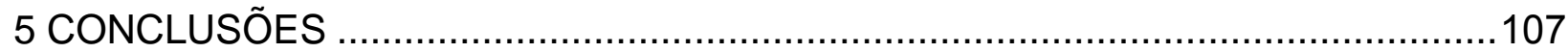

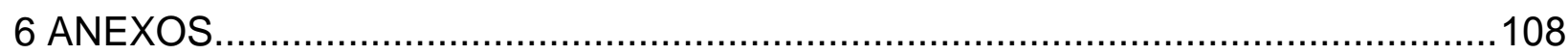

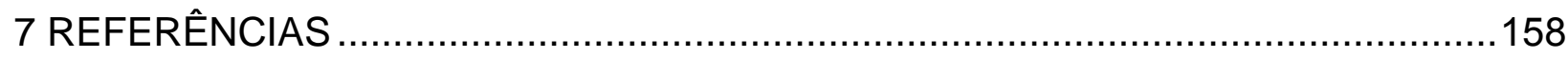

Abstract 


\section{Lista de figuras}

Figura 1. Etapas da extração e processamento da medula óssea para isolamento de células-tronco mesenquimais 13

Figura 2. Procedimento cirúrgico de desestabilização do menisco medial 18

Figura 3. Transplante intravenoso 19

Figura 4. Transplante intra-articular 20

Figura 5. Fluxograma do delineamento experimental agudo .22

Figura 6. llustração das intervenções experimentais .23

Figura 7. Fluxograma do delineamento experimental longitudinal .24

Figura 8. Dissecação da articulação do joelho 27

Figura 9. Órtese de termoplástico .29

Figura 10. Avaliação de descalcificação por Raio-X. 30

Figura 11. Coleta do Lavado Sinovial 32

Figura 12. Radiografia da peça histológica da articulação do joelho. .35

Figura 13. Marcação articular para marcha 2D. .38

Figura 14. Análise da marcha pelo software Kinovia ${ }^{\circledR} 8.2$ .39

Figura 15. Sistema CatWalk ${ }^{\circledR}$ 41

Figura 16. Sistema Rotarod ${ }^{\circledR}$ .42

Figura 17. Escada do teste de escalada. .43

Figura 18. Imagem ilustrativa da dissecação muscular do membro inferior .44

Figura 19. Visão interna e externa do quadríceps, gastrocnemio/sóleo e tibial anterior, dissecados para pesagem. .45

Figura 20. Colônias de células tronco mesenquimais, após isolamento. .48

Figura 21. Diferenciação celular em linhagens mesenquimais .49

Figura 22. Diferenciação condrogênica em micromassa .50

Figura 23. Caracterização de células-tronco mesenquimais de medula óssea .

Figura 24. Curva de viabilidade celular por concentração de puromicina, detectados pela absorbância de MTT .52

Figura 25. Ensaio de atividade de Luciferase in vitro ... .53

Figura 26. Avaliação da capacidade de detecção das células de acordo com a via de transplante. .54 
Figura 27. Avaliação do sinal de luminescência ex vivo duas horas após transplante intravenoso.

Figura 28. Cinética de luciferina/luciferase do transplante intra-articular. 55

Figura 29. Cinética de luciferina/luciferase do transplante intravenoso .56

Figura 30. Sinal de luminescência, ao longo do tempo, após transplante intra-articular ou intravenoso.

Figura 31. Intensidade máxima do sinal de luminescência, ao longo do tempo, após transplante intra-articular ou intravenoso .58

Figura 32. Delta entre tempos de coleta da intensidade máxima do sinal de luminescência. 58

Figura 33. Imunocitoquímica Anti-FireFly Luciferase .59

Figura 34. Imuno-histoquímica Anti-FireFly Luciferase. 60

Figura 35. Controle experimental da citometria de fluxo por imagem

Figura 36. Estratégia de seleção da população de eventos, a ser analisada na citometria de fluxo por imagem.

Figura 37. Dotplot da identificação de eventos duplo positivos, na citometria de fluxo por imagem.

Figura 38. Imagens de eventos celulares obtidos da digestão do pulmão 65

Figura 39. Imagens de eventos celulares, obtidos da digestão do joelho com desestabilização do menisco medial .66

Figura 40. Tecido pulmonar, 12 horas após o transplante celular intravenoso com marcação fluorescente de membrana celular

Figura 41. Visão superior de microscopia confocal da cartilagem articular do joelho, removida do platô tibial. 68

Figura 42. Peso muscular normalizado pela massa corporal 69

Figura 43. Comparação do equilíbrio muscular de membros inferiores entre grupos...71

Figura 44. Comparação do equilíbrio muscular de membros inferiores entre vias de transplante .72

Figura 45. Curva do padrão normal da marcha (área cinza) para a articulação do joelho

Figura 46. Curva do padrão normal da marcha (área cinza) para a articulação do tornozelo. 73

Figura 47. Curva do padrão normal da marcha (área cinza) para a articulação do quadril. .74 
Figura 48. Baropodometria com sistema CatWalk ${ }^{\circledR}$

Figura 49. Avaliação de performance motora antes (Pré) e nove semanas após (Pós) intervenção cirúrgica

Figura 50. Radiografia das articulações do joelho, após nove semanas da cirurgia de desestabilização do menisco medial .77

Figura 51. Radiografia do joelho, após tratamentos .78

Figura 52. Coloração histológica da cartilagem articular por Safranina-O, quatro semanas, após tratamento celular .79

Figura 53.Coloração histológica da cartilagem articular por Safranina-O, 12 semanas após tratamento celular .80

Figura 54. Quantificação histológica do grau de osteoartrose no platô tibial medial ....81 Figura 55. Imuno-histoquímicada cartilagem para Colágeno I e Il quatro semanas após tratamento celular. .82

Figura 56. Análise da hiperplasia celular da membrana sinovial, após quatro e 12 semanas do transplante celular 83

Figura 57. Comparação pareada de níveis séricos de citocinas .84

Figura 58. Comparação dos níveis séricos de citocinas ao do estudo agudo .86

Figura 59. Comparação de níveis séricos de IL-1 $1 \beta$, IL-18 e MCP-1, entre grupos 88

Figura 60. Comparação de níveis séricos de MIP-1 $1 \alpha$, IL-10 e RANTES, entre grupos 89 Figura 61. Comparação de níveis séricos de citocinas, com relação a via de transplante celular 90

Figura 62. Heatmap do resultado global do ensaio Luminex para as amostras de lavado sinovial 91

Figura 63. Comparação dos níveis das citocinasIL-1ß, IL-18 IL-10 e RANTES no lavado sinovial concentrado .92

Figura 64. Comparação de níveis de citocinas, no lavado sinovial concentrado, com relação a via de transplante celular .93 


\section{Lista de abreviaturas e símbolos}

a-MEM

2MT

$4 S$

$12 S$

AAALAC

ACAN

$\mathrm{AH}$

AMP

bFGF

$C A$

CCL2

CCL3

CCL5

CCR1

CCR5

CD

CEUA

$\mathrm{Cl}$

CMF

COL II

cox

CTMs

DAMPs

DMSO

DMM

DMM+CTM-IAt

DMM+CTM-IAt-4S
Meio essencial mínimo de Eagle com modificação a

Segundo metatarso

Quatro semanas

Doze semanas

Association for Assessment and Accreditation of Laboratory

Animal Care

Agrecam

Ácido hialurônico

Área média da pegada

Basic Fibroblast Growth Factor

Cartilagem articular

Chemokine ( $C-C$ motif) Ligand 2

Chemokine ( $\mathrm{C}-\mathrm{C}$ motif) Ligand 3

Chemokine ( $\mathrm{C}-\mathrm{C}$ motif) Ligand 5

$C$-C chemokine receptor type 1

C-C chemokine receptor type 5

Cluster of Diferentiation

Comitê de Ética em Experimentação e Uso Animal

Crista llíaca

Côndilo medial do fêmur

Colágeno tipo II

Ciclooxigenase

Células-tronco mesenquimais

Damage-Associated Molecular Patterns

Dimetilsulfóxido

Desestabilização do menisco medial

Grupo com cirurgia DMM e tratamento de células-tronco mesenquimais intra-articular

Grupo com cirurgia DMM e tratamento de células-tronco mesenquimais intra-articular de quatro semanas 
DMM+CTM-IAt-12S Grupo com cirurgia DMM e tratamento de células-tronco mesenquimais intra-articular de doze semanas

$\mathrm{DMM}+\mathrm{CTM}-\mathrm{IVt}$ Grupo com cirurgia DMM e tratamento de células-tronco mesenquimais intravenoso

DMM+CTM-IVt-4S Grupo com cirurgia DMM e tratamento de células-tronco mesenquimais intravenoso de quatro semanas

DMM+CTM-IVt-12S Grupo com cirurgia DMM e tratamento de células-tronco mesenquimais intravenoso de doze semanas

DMM+PLACEBO-IAt Grupo com cirurgia DMM e tratamento placebo intra-articular

DMM+PLACEBO-IAt-4S Grupo com cirurgia DMM e tratamento placebo intra-articular de quatro semanas

DMM+PLACEBO-IAt-12S Grupo com cirurgia DMM e tratamento placebo intra-articular de doze

DMM+PLACEBO-IVt Grupo com cirurgia DMM e tratamento placebo intravenoso

DMM+PLACEBO-IVt-4S Grupo com cirurgia DMM e tratamento placebo intravenoso de quatro semanas

DMM+PLACEBO-IVt-12S Grupo com cirurgia DMM e tratamento placebo intravenoso de doze semanas

EDTA Ácido Etilenodiamino Tetra-acético

EUA Estados Unidos da América

GAGs Glicosaminoglicanos

G-IAt Grupo intra-articular

G-IVt Grupo Intravenoso

GVHD Doença do enxerto versus hospedeiro

hCTMs

Células-tronco mesenquimais humanas

HIAE Hospital Israelita Albert Einstein

HLA Human Leukocyte Antigen

IA Intra-articular

IAM lodoacetato monosódico

IAt Transplante intra-articular

ICA Implante de condrócitos autólogos

IDO Indoleamine 2,3-dioxygenase

IFNy Interferon gamma Interleucina 1 beta 


\begin{tabular}{|c|c|}
\hline IL-1 & Interleucina 1 \\
\hline IL-4 & Interleucina 4 \\
\hline IL-6 & Interleucina 6 \\
\hline IL-8 & Interleucina 8 \\
\hline IL-10 & Interleucina 10 \\
\hline IL-13 & Interleucina 13 \\
\hline IL-18 & Interleucina 18 \\
\hline IMaxP & Intensidade Máxima da pegada \\
\hline IMdP & Intensidade Média da Pegada \\
\hline ISCT & International Society for Cellular Therapy \\
\hline ITS & Insulin-Transferrin-Selenium \\
\hline IV & Intravenoso(a) \\
\hline $\mathrm{IVt}$ & Transplante intravenoso \\
\hline LMTM & Ligamento Meniscotibial Medial \\
\hline LS & Lavado Sinovial \\
\hline M1 & Macrófagos tipo 1 \\
\hline M2 & Macrófagos tipo 2 \\
\hline $\mathrm{MC}$ & Massa Corporal \\
\hline MCP & Metacarpophalangeal \\
\hline MCP-1 & Monocyte Chemoattractant Protein \\
\hline MI & Membro inferior \\
\hline MICL & Membro inferior contralateral não operado \\
\hline MIOA & Membro inferior operado \\
\hline MIP-1 $1 \alpha$ & Macrophage Inflamatory Protein 1 alpha \\
\hline ML & Maléolo Lateral \\
\hline MMPs & Matrix Metalloproteinases \\
\hline $\mathrm{MOI}$ & Multiplicity of infection \\
\hline MSCs & Mesenchymal stem cells \\
\hline MTT & 3-(4, 5-dimethylthiazolyl-2)-2,5-diphenyltetrazolium bromide \\
\hline NKs & Células Natural Killers \\
\hline $\mathrm{OA}$ & Osteoartrose \\
\hline OARSI & Osteoarthritis Research Society International \\
\hline ON & Óxido nítrico \\
\hline PBS & Salina tamponada com fosfato \\
\hline
\end{tabular}


PDGF

PFA

PFV

PGE2

PRP

PTM

RANTES

SFB

SDF-1

SHAM

SHAM+CTM-IAt

SHAM+CTM-IAt-4S

SHAM+CTM-IAt-12S

SHAM+CTM-IVt

SHAM+CTM-IVt-4S

SHAM+CTM-IVt-12S

TGF- $\beta$

TH1/TH17/TH2/TH4

TM

TNF- $\alpha$

VE

VEGF

VM

VT

WOMAC
Platelet-derived growth factor

Paraformaldeído

Proteína fluorescente vermelha

Prostaglandina E2

Plasma rico em plaqueta

Platô tibial medial

Regulated on activation, normal $T$ cell expressed and secreted

Soro fetal bovino

Stromal cell-derived factor 1

Falso(a)

Grupo com intervenção cirúrgica falsa e tratamento celular intra-arterial

Grupo com intervenção cirúrgica falsa e tratamento celular intra-arterial de quatro semanas

Grupo com intervenção cirúrgica falsa e tratamento celular intra-arterial de doze semanas

Grupo com intervenção cirúrgica falsa e tratamento celular intravenoso

Grupo com intervenção cirúrgica falsa e tratamento celular intravenoso de quatro semanas

Grupo com intervenção cirúrgica falsa e tratamento celular intravenoso de doze semanas

Transforming Growth Factor beta

$T$ Helper cell

Trocânter maior do fêmur

Tumor Necrosis Factor alpha

Vesícula extracelular

Vascular endotelial growth factor

Velocidade limite de marcha

Velocidade anterior a transição marcha/corrida

The Western Ontario and McMaster Universities Arthritis Index 


\section{Resumo}

Introdução: A osteoartrose constitui uma patologia articular progressiva, que acomete, principalmente, a cartilagem articular, causando sua degeneração, dor e limitações locomotoras. Terapia celular, com células-tronco mesenquimais, para regeneração da cartilagem, tem demonstado ser uma alternativa potencial no tratamento da osteoartrose, devido sua ampla atuação imunomoduladora. Porém, ainda se faz necessário identificar qual é a melhor via de administração celular (intra-articular ou intravenosa) para optimização do transplante. Objetivos: Avaliar as vias de administração para transplante celular sistêmico (intravenoso) e local (intra-articular), quanto à capacidade regenerativa da cartilagem articular. Métodos: Utilizou-se um modelo animal (rato) de osteoartrose, induzida por cirurgia de desestabilização do menisco medial ou por cirurgia falsa sem lesão; o rastreamento das células in vivo foi realizado por bioluminescência, citometria de fluxo de imagem e microscopia confocal; a imunomodulação pró e anti-inflamatórias no soro e lavado sinovial foram avaliadas por multiplex de beads magnéticas; a capacidade regenerativa das células transplantadas, avaliadas histologicamente. Também passaram por avaliação a marcha, a performance funcional e o equilíbrio muscular dos membros inferiores. Resultados: O modelo animal utilizado, após nove semanas, não alterou padrão de marcha, porém reduziu a performance funcional e gerou atrofia do quadríceps, gastrocnêmio/sóleo e tibial anterior. As células transplantadas permaneceram viáveis no joelho operado, até uma semana após transplante intra-articular. Foi possível detectar bioluminescência ( 8 horas; $\mathrm{N}=1$ ) e eventos positivos, por citometria de fluxo de imagem (12 horas; $\mathrm{N}=2$ ), no joelho com lesão após transplante celular intravenoso. As principais alterações de citocinas ocorreram, em até 24 horas após transplante celular, com aumento da expressão de MCP-1 e RANTES, por via intra-articular, MIP-1a e IL10 por via intravenosa. Essa expressão se reduziu, após uma semana, para ambas as vias. Imunossupressão de citocinas inflamatórias ocorreram, principalmente, para o transplantecelular (MCP-1, RANTES, MIP-1a, IL-18), em comparação com o placebo. Esse efeito supressor foi observado, também, no lavado sinovial, quanto à concentração de IL-18, em quatro semanas, após transplante intra-articular de células em relação ao placebo. O tratamento celular intravenoso não apresentou o mesmo efeito imunossupressor em curto prazo, além de apresentar maior concentração de IL- 
$1 \beta$, após uma semana em comparação a via intra-articular. Porém, apresentou redução de RANTES a longo prazo, quatro e 12 semanas, em comparação ao transplante placebo. Contudo, o transplante celular intra-articular reduziu a atrofia muscular do tibial anterior, por até quatro semanas após tratamento, em comparação ao transplante celular intravenoso e ao placebo intra-articular. Não se fez possível observar alterações histológicas de redução, referentes a degeneração da cartilagem articular, para nenhuma via ou tempo, analisados após transplante. Conclusões: O modelo animal de desestabilização do menisco medial apresentou evolução lenta, com características similares a osteoartrose em humanos. Também, um único transplante intra-articular ou intravenoso de células-tronco mesenquimais não se mostrou suficiente para reduzir a progressão da osteoartrose, gerada pelo modelo animal, nove semanas após cirurgia, independente do tempo analisado. Apesar dos indícios de capacidade de homing das células administradas, sistemicamente, e controle, a longo prazo, de uma citocina inflamatória, as análises evidenciaram uma ação celular imunossupressora e tecidual, mais evidente para células administradas, localmente, no tratamento da osteoartrose.

Descritores: Osteoartrite/terapia; Osteoartrite/cirurgia; Transplante de células-tronco mesenquimais; Ratos Wistar 


\section{INTRODUÇÃO}

Conhecida, popularmente, por provocar dor e redução da mobilidade nas articulações afetadas, a osteoartrose (OA) constitui a doença articular degenerativa mais comum e apresenta, como principal característica, o desgaste da cartilagem articular (CA). ${ }^{(1)}$ A OA constitui alvo de amplo interesse à saúde pública e sistemas de saúde. Isso porque se trata de uma doença relacionada, principalmente, ao envelhecido, e mais de $70 \%$ da população mundial, acima de 65 anos, sofre com algum grau de OA. ${ }^{(2)}$ Segundo a Organização Mundial da Saúde, a OA está entre as 10 principais patologias com maior número de "anos vividos com doença", em vários países e, ainda, é considerada a segunda doença musculoesquelética mais prevalente no mundo. ${ }^{(3)}$

Devido ao aumento da perspectiva de vida e, consequentemente, da população idosa, a previsão de incidência de $O A$ não parece ser favorável nos próximos anos. Considerando-se que, no estágio avançado da OA (ex.: joelho), faz-se necessária uma cirurgia de artroplastia total ou parcial. Estudos estimam que o número de procedimentos cirúrgicos invasivos nos EUA triplique até $2030,{ }^{(4)}$ ocasionando importante aumento de gastos para os sistemas de saúde. ${ }^{(5)}$ No Brasil, os casos de OA representam de 30 a $40 \%$ de todas as consultas, realizadas em ambulatórios de reumatologia, além de serem responsáveis por $7,5 \%$ dos afastamentos do trabalho. ${ }^{(6)}$

Além do envelhecimento, existem outros fatores de risco ao desenvolvimento de $\mathrm{OA}$, tais como: gênero, obesidade, sedentarismo, hereditários e traumas articulares prévios. ${ }^{(7,8)}$ Mulheres tendem a desenvolver a doença mais cedo ( $>40$ anos) e ter quadros mais severos do que os homens ( $>50$ anos). A anatomia feminina possui algumas características favoráveis a patogênese da OA, como é o caso às articulações dos membros inferiores, principalmente do joelho, pois a estrutura do quadril mais largo gera um posicionamento angular articular acentuado em valgo, ${ }^{(9)}$ compartimentalizando o desgaste da CA. Esse fato, somado ao menor volume e força muscular, contribuem para uma maior instabilidade articular e desenvolvimento da OA. Também, após entrarem em menopausa, o desbalanço hormonal dos níveis de estrogênio parece facilitar o desenvolvimento da OA. Os mecanismos que relacionam a redução deste hormônio com a OA ainda não são completamente esclarecidos, porém 
parecem estar relacionados com os receptores $\alpha$ e $\beta$ de estrógeno presentes em células da articulação. ${ }^{(8,10)}$

Dentre tais fatores, a obesidade e inatividade física caminham juntas, sendo um alvo claro para tratamentos e prevenção. Calcula-se que, em média, uma pessoa aumente o risco de desenvolver OA sintomática em $60 \%$, com um índice de massa corpórea acima de $30 .{ }^{(8)}$ Além dos aspectos biomecânicos, envolvendo a questão do aumento de carga nas articulações, a obesidade também induz certo nível de inflamação sistêmica, mediada por adipocinas (Leptina e Adiponectina). Esse quadro inflamatório, somado a outras comorbidades provenientes da obesidade, como diabetes e hipertensão já mostraram ser capazes de afetar o ambiente articular. ${ }^{(11)}$

Associada ao controle de peso, considera-se atividade física tão imprescindível quanto, não apenas para manter uma qualidade de vida saudável e prevenir a $O A$, mas também para melhorar a condição neuromuscular e reduzir a progressão da doença, quando já instalada. ${ }^{(12)}$ Os benefícios da atividade física para pacientes com OA não estão apenas no âmbito neuromuscular e biomecânico da marcha. Estudos de mecanobiologia também já demonstraram ser a CA beneficiária de cargas mecânicas controladas. Os efeitos condroprotetores, promovidos por esses estímulos, ajudam a manter a homeostase articular, por interméio da supressão de citocinas inflamatórias, como Interleucina 1 beta (IL-1 $\beta$ ), Interleucina 6 (IL-6) e Tumor Necrosis Factor alpha (TNF- $\alpha$ ); produzir fatores anti-catabólicos, Interleucina 10 (IL-10) e Interleucina 4 (IL-4); e pró-anabólicos fator basic Fibroblast Growth Factor (bFGF) Transforming Growth Factor Beta (TGF- $\beta)^{(13,14)}$

A CA, estrutura responsável pela absorção do impacto intra-articular (IA), forma-se por redes de colágeno, proteoglicanos e ácido hialurônico (AH). Os glicosaminoglicanos (GAGs) presentes nessas estruturas, como sulfato de condroitina e sulfato de Keratan são responsáveis por absorver e liberar água, durante o impacto ou estímulo mecânico, auxiliando no amortecimento da carga. ${ }^{(15)}$ Envolto por essas estruturas ficam os condrócitos, um tipo celular específico, que desempenha o papel de manutenção da cartilagem. Os condrócitos são células com caráter quiescente e responsáveis, principalmente, pela produção de matriz extracelular para manutenção da cartilagem. Ao ocorrer uma lesão na CA, os condrócitos residentes próximos a ela se tornam ativos e passam a tentar repará-la. Contudo, a capacidade regenerativa dos condrócitos é baixa e a lesão não se repara, ou se repara, parcialmente,com estruturas hipertróficas sem as mesmas funções biomecânicas. ${ }^{(16)}$ 
$\mathrm{Na} \mathrm{OA}$, a degeneração da cartilagem também se dá, acompanhada de outras alterações importantes. A hiperplasia sinovial, decorrente da inflamação da sinovial, constitui uma das alterações mais importantes do quadro de $O A$, isto porque na sinóvia estão os sinoviócitos - células responsáveis pela produção do líquido sinovial, importante componente das articulações sinoviais com função lubrificante. Os detritos da degeneração da cartilagem causam a inflamação da membrana sinovial, hiperplasia, infiltração de macrófagos, e essa, por sua vez, libera fatores inflamatórios para o interior da articulação, reduz a produção do líquido sinovial, ocasionando um feedback negativo e progressivo. ${ }^{(17)}$

$O$ osso subcondral também exerce um papel importante no desenvolvimento da OA. Com a redução da absorção de impacto pela cartilagem doente, ocorre o espessamento do osso subcondral. Tal espessamento pode gerar deformidades na região subcondral, alterando a superfície da CA. ${ }^{(18)}$

$O$ enfraquecimento muscular, de ligamentos e tendões adjacentes a articulação afetada, hiperplasia sinovial, espessamento da cápsula articular, formação de anormalidades ósseas adjacentes (osteófitos) a superfície articular e redução do líquido sinovial, também são alterações decorrentes da $O A .^{(7,19,20)}$

Em articulações afetadas por OA, ocorre o acúmulo de citocinas inflamatórias, Damage-Associated Molecular Patterns (DAMPs) e Matrix Metalloproteinases (MMPs) - responsáveis pela degradação do tecido cartilaginoso e estabelecimento do quadro inflamatório. ${ }^{(21,22)} \mathrm{O}$ primeiro sinal de desgaste da cartilagem é a diminuição da quantidade de GAGs, seguida da morte de condrócitos e desgaste da matriz de colágeno da CA. Recentemente, Heinemeier et al. ${ }^{(23)}$ mostraram que o maior turnover, ao longo da vida que ocorre na CA, é pelos GAGs, enquanto que as estruturas de colágeno, uma vez geradas após o desenvolvimento do corpo para fase adulta, não se renovam, demonstrando a falha na capacidade de regeneração da CA.

O diagnóstico da $\mathrm{OA}$, hoje, é, basicamente, feito por análises clínicas e de imagens de radiografia ou ressonância magnética da articulação afetada. ${ }^{(24)}$ Análises de biomarcadores presentes no soro sanguíneo, como proteínas oligoméricas de matriz, ${ }^{(25)}$ Metaloproteinases de matriz e inibidor de protease de tecidos $^{(26)}$ e $A H,{ }^{(27)}$ auxiliam no diagnóstico da $O A$, porém ainda não constituem uma prática clínica, pois necessitam de mais validações. Essa dificuldade de diagnóstico mais precoce constitui um complicador, pois em geral o paciente procura o médico, 
quando a OA se torna sintomática (presença de dor), inviabilizando um trabalho mais inicial de prevenção.

Atualmente, algumas organizações como "Osteoarthritis Research Society International (OARSI)","European League Against Rheumatism" e "American College of Rheumatology" se dedicam a compreender melhor as facetas dessa doença e gerar direcionamentos e recomendações ${ }^{(28-30)}$ para prevenção e tratamento da mesma. Essas recomendações, hoje, encontram-se, cada vez mais, direcionadas e específicas. Dentre essas abordagens, encontra-se o desenvolvimento de diagnósticos diferenciados com o aprimoramento de técnicas de imagem, análises de sangue e urina, e estudos em busca de aspectos da patologia que possibilitem diferenciar a OA em subtipos, por exemplo, OA inflamatória ou mecânica, primária (envelhecimento) ou secundária (decorrente de obesidade ou trauma).

Os tratamentos disponíveis para OA, atualmente, seguem uma determinada sequência ao tipo de tratamento a ser utilizado, de acordo com o grau de acometimento da articulação. Primeiramente, após o diagnóstico da doença há uma série de informações obtidas pelo paciente, com relação a hábitos e costumes. Então, quando possível, o acompanhamento nutricional para controle do peso e a prática de atividade física são a primeira linha de abordagem e tratamento. Seguido, encontra-se o uso de drogas anti-inflamatórias não esteroidais, a fim de reduzir a inflamação e alívio de dor. Uma abordagem mais invasiva começa com a aplicação de AHIA. Por ser um subproduto, presente na estrutura dos proteoglicanos, inicialmente, o tratamento com $\mathrm{AH}$ começou com o intuito de promover regeneração da CA. Porém, os resultados apresentados, atualmente, demonstram um efeito positivo moderado do $\mathrm{AH}$ para redução de dor e melhora de função a curto prazo, sem sinais de regeneração. ${ }^{(31)} \mathrm{Na}$ mesma linha que o $\mathrm{AH}$, encontram-se os corticoides - comumente aplicados na articulação, promovendo a redução da dor. ${ }^{(32)}$

Quando nenhuma das abordagens se faz mais possível, e o grau de desgaste articular encontra-se muito elevado, o paciente se submete à cirurgia para substituição total ou parcial da articulação. ${ }^{(28,29,33)}$

Em contraposição aos métodos convencionais, os avanços na área da medicina regenerativa proporcionaram novas abordagens sobre a OA. Estudos utilizando tecnologias de engenharia tecidual e de terapia celular estão se desenvolvendo, cada vez mais, surgindo assim novas possibilidades de tratamento para reparo da cartilagem. ${ }^{(34)}$ 
As primeiras abordagens de terapia celular, para regeneração da cartilagem, começaram com a utilização de implante de condrócitos autólogos (ICA) no local de lesão focal osteocondral. ${ }^{(35,36)}$ Tal técnica tem o intuito de proporcionar um preenchimento de cartilagem, novamente por produção de matriz extracelular, a partir da ação dos condrócitos no local da lesão. Consiste em dois procedimentos cirúrgicos: o primeiro, com o intuito de extrair um fragmento de cartilagem de uma região saudável da superfície articular e que esteja fora de zonas de sobrecarga, para que a articulação não seja comprometida. Então, por procedimentos enzimáticos, os condrócitos são extraídos da matriz cartilaginosa, colocados para cultivo e expansão em cultura. Após atingir um número de células adequado, um segundo procedimento cirúrgico se realiza, no qual preenche-se o defeito por células, coberto com periósteo ou membranas de colágeno.

Existem diversos clinicaltrials que utilizaram desta técnica de transplante. Ogura et al. ${ }^{(36)}$ analisando os resultados de 24 joelhos, em estudo de casos com follow-up de 20 anos, observaram que 15 pacientes tiveram a retenção do transplante, enquanto nove falharam. Os 15 bem-sucedidos apresentaram melhores valores no teste The Western Ontario and Mc Master Universities Arthritis Index (WOMAC). Também, uma revisão sistemática com avaliação econômica recente ${ }^{(35)}$ do National Institute for Health concluiu que, o custo-efetividade do $\mathrm{ACl}$, aumentou nos últimos anos, porém ainda carece-se de mais estudos, a fim de avaliação de novos métodos existentes de implante de condrócito autólogo.

Entretanto, a abordagem de $\mathrm{ACI}$ não contempla a $\mathrm{OA}$ - uma doença comprometedora de toda a articulação. Outra abordagem, também bastante explorada, consiste no transplante de plasma rico em plaquetas (PRP). Essa técnica se dá no processamento do sangue total, por centrifugação, eliminando células vermelhas. $O$ efeito da aplicação do PRP viria do estímulo ao aumento da vascularização - vascular endotelial growth fator (VEGF) e por fatores de crescimento - platelet-derived growth factor (PDGF); TGF- $\beta$, geralmente envolvidos em processos de cicatrização e regeneração tecidual. ${ }^{(37)}$ Porém, esse tratamento possui algumas críticas, devido a falta de padronização da técnica de produção do PRP. Apesar de o PRP, aparentemente, ter efeito positivo em dor e função quando comparado ao placebo (salina), ${ }^{(38)}$ ainda não está claro se este tratamento pode ser considerado superior ao $\mathrm{AH}$. Zhang et al., ${ }^{(39)} \mathrm{em}$ uma meta análise, concluiram que o tratamento de OA, com administração IA de PRP 
não apresenta desfechos superiores a injeção de $\mathrm{AH}$, e atribui essa questão a qualidade dos estudos clínicos.

Com o intuito de promover regeneração da cartilagem, um outro tipo celular foi colocado em foco, as células-tronco mesenquimais (CTMs). ${ }^{(40-42)}$ As CTMs são multipotentes, possuem a capacidade de se diferenciar em linhagens mesenquimais, como condrogênicas, adipogênicas, osteogênicas, hematopoiéticas e músculoesqueléticas. Esse tipo celular pode ser isolado, de vários tecidos mesenquimais diferentes, por exemplo: medula óssea, tecido adiposo, cordão umbilical. ${ }^{(43,44)}$

O processo de isolamento dessas células se realiza, basicamente, pela sua capacidade de aderência ao plástico em cultura. De acordo com o local do qual forem isoladas, a capacidade de diferenciação em cada linhagem mesenquimal pode variar, pois possui uma população mista, e parte das células já estarão acometidas para uma linhagem específica. ${ }^{(45)}$

A International Society for Cellular Therapy (ISCT) estabeleceu critérios mínimos de padrão de qualidade, a fim de determinar se uma população celular procede, de fato, de CTMs. Necessário se faz as células terem capacidade de diferenciação, em pelo menos adipogênese, osteogênese, condrogênese, expresse os marcadores positivos de superfície CD90, CD105, CD73 ( $\geq 95 \%)$ e não expresse os marcadores negativos CD45, CD34, CD14, CD11b, CD79a CD19 e Human Leukocyte Antigen (HLA) $(\leq 0,2 \%) .{ }^{(46)}$

Com os avanços das pesquisas sobre esse tipo celular, a nomenclatura de célula-tronco vem sendo questionada. Apesar da capacidade de diferenciação in vitro, esse potencial não se reflete in vivo. A maior parte dos estudos tem relatado a eficiência dessas células, em interagirem com o ambiente transplantado de forma parácrina, com produção de fatores de crescimento, citocinas e quimiocinas. Por este motivo, alguns pesquisadores defendem ser a nomenclatura correta células estromais mesenquimais, ${ }^{(47)}$ ou células sinalizadoras medicinais. ${ }^{(48)}$ Nesta tese utilizouse a nomenclatura "células-tronco mesenquimais" para referir-se a este tipo celular.

Além desta discussão sobre a capacidade de atuação dessas células, também existe a hipótese de que as CTMs sejam provenientes de células perivasculares, ou pericitos, ${ }^{(49,50)}$ situando-se como uma célula perivascular na microvascularização de tecidos mesenquimais. Tal hipótese surgiu, devido ao fato de a localização das CTMs no organismo, em tecidos conhecidos por disponibilidade de 
realizar seu isolamento, serem regiões de "nichos microvasculares", nos quais são mantidos o equilíbrio celular e de autorrenovação entre células comprometidas e células progenitoras quiescentes. ${ }^{(51-54)}$ Crisan et al. ${ }^{(50)}$ demonstraram que pericitos CD146 ${ }^{+}$CD34- apresentam a mesma capacidade de diferenciação e os mesmos marcadores de superfície das células-tronco mesenquimais. Complementando esses dados, Lin et al. ${ }^{(55)}$ mostraram que CTMs imortalizadas, após transplante intra-arterial, migraram para o local da lesão, em modelo animal de irradiação, e se alojaram em regiões perivasculares na medula óssea próxima a lesão. Esses dados ajudam a elucidar um possível mecanismo de ação dessas células, alojadas em regiões perivasculares, próximas e atuariam de forma parácrina para manter a homeostase do tecido, ao invés de se diferenciarem para o tecido em questão.

O interesse da utilização de CTMs ao tratamento de OA encontra-se relacionado, principalmente, a sua capacidade de proporcionar efeitos regenerativos. $^{(40-42)}$ A característica mais promissora das CTMs está em sua capacidade imunomodulatória. ${ }^{(43,56,57)}$ Por meio de interações célula-célula ou célulaambiente, são capazes de reconhecer sinais de inflamação e produzir um efeito imunossupressor anti-inflamatório, a partir da polarização de macrófagostipo 1 (M1) ao macrófagos tipo 2 (M2), células THelper1/THelper17 (TH1/TH17) ao THelper2 (TH2), impedir a proliferação de células T CD8+ e diminuir a atividade de células natural killers (NKs). ${ }^{(58)}$ Essas alterações ocorrem, principalmente, pela produção de Indoleamine 2,3dioxygenase (IDO),óxido nítrico (ON), Prostaglandina E2 (PGE2) e IL-10. ${ }^{(47)}$ Porém, a fim de que essa cascata regulatória ocorra, as CTMs precisam ser expostas à sinalização de citocinas inflamatórias do tecido lesionado, principalmente IL-1 e de Interferongamma (IFNY), com o intuito de serem ativadas e iniciarem a ação paracrina. ${ }^{(58)}$

As CTMs, quando expostas em cocultura com condrócitos, provenientes de cartilagem osteoartrítica, promovem diversos efeitos positivos. A interação ocorre, tanto em cocultura com contato, como em cocultura sem contato. ${ }^{(59)}$ As CTMs produzem altos níveis de $\mathrm{AH}$, uma molécula presente tanto na cartilagem quanto no fluído sinovial, enquanto condrócitos osteoartríticos apresentam baixos níveis de produção desta molécula. Também, condrócitos osteoartríticos produzem altos níveis de IL6, IL8, IL1ß e, a interação in vitro com CTMs é capaz de reduzir a produção dessas moléculas pró-inflamatórias. ${ }^{(60)}$ 
A ação das células mesenquimais na produção de $\mathrm{AH}$ está vinculada ao aumento na expressão de Hialurônico Acid Sintase 1 (HAS1), ${ }^{(61)}$ responsável pela síntese de moléculas de $\mathrm{AH}$ de alto peso molecular. Fragmentos de $\mathrm{AH}$, com alto peso molecular, apresentam características antiangiogênicas e propriedades antiinflamatórias e imunosupressoras. ${ }^{(62)}$

A cocultura de CTMs com condrócitos também aumenta a produção de constituintes de matriz extracelular, como GAGs, por intermédio do aumento da expressão de genes, como agrecam (ACAN) e colágeno tipo II (COL II). ${ }^{(63)}$

Esses achados sugerem um cenário no qual, inicialmente, as CTMs modificariam o microambiente na articulação osteoartrítica pela supressão das citocinas inflamatórias, permitindo a ação dos fatores estimuladores da síntese de componentes da matriz cartilaginosa (como o $\mathrm{AH}$ ) e a recuperação da CA. ${ }^{(61,64-67)}$

Murphy et al. ${ }^{(68)}$ foram os primeiros a demonstrarem estudo in vivo o efeito positivo das CTMs em modelo animal de OA em caprinos. Eles utilizaram um modelo de transecção do ligamento cruzado anterior, com remoção do menisco medial e fizeram a aplicação de $1 \times 10^{7}$ células. Após 12 a 26 semanas, observaram redução da degeneração da cartilagem, formação de osteófitos e esclerose do osso subcondral, em comparação com o membro não tratado. Seguindo esse estudo in vivo, diversos outros surgiram com diferentes modelos animais e fontes de células mesenquimais. ${ }^{(69)}$ A escolha do modelo apresenta-se como de extrema importância, pois existem vários tipos e cada um apresenta semelhanças e disparidades com a fisiopatologia da OA em humanos. ${ }^{(70)}$ Em meta análise Xing et al., ${ }^{(71)}$ observaram que, apesar de o número de estudos, até o momento, ter produzido um nível moderado de confiança, em relação a segurança do transplante celular para $\mathrm{OA}$, a eficácia do tratamento apresenta um baixo nível de confiança, devido a limitações metodológicas, sendo necessários mais estudos com maior rigor, a fim de modificar este cenário.

Os estudos relatando os efeitos benéficos das CTMs à OA se utilizam de modelos animais inflamatórios, ${ }^{(69)}$ como, injeção IA de enzimas (Colagenase) $^{(72)}$ ou desestabilização articular severa ${ }^{(68)}$ (transecção do ligamento cruzado anterior). Nesses estudos, apesar do resultado positivo, as células foram administradas durante a resposta inflamatória inicial, logo após o procedimento experimental, ou seja, antes da instalação do desgaste da CA. Portanto, é provável que esse efeito seja decorrente da redução do processo inflamatório inicial, e não da regeneração da CA de fato. 
Entretanto, quando se considera o uso de células-tronco para o tratamento de OA em humanos, deve-se levar em conta que o modelo experimental precisa refletir o cenário fisiopatológico, próximo ao quadro clínico em que o uso da terapia celular se vê considerado. Em geral, um quadro já estabelecido de degeneração da $\mathrm{CA}$, intermediário entre a patogênese, ou quadro inflamatório agudo pós-traumático, e o estado mais crítico e cirúrgico, já com acometimento do osso subcondral.

Dentre os diferentes modelos animais de $\mathrm{OA},{ }^{(70)}$ o modelo cirúrgico de desestabilização do menisco medial (DMM) demonstra ser ideal, quando se pensa em OA, pois apresenta uma progressão lenta e, aproximadamente, após oito semanas da cirurgia, as alterações da expressão gênica, decorrente, da cirurgia, já estão estabilizadas. ${ }^{(73,74)}$

Apesar de, em modelos animais a qualidade em relação a eficácia do tratamento ser baixa, existem hoje 102 estudos clínicos registrados no ClinicaTrials.gov, sob os termos "mesenchymal stem cells/ osteoarthritis", e destes, 78 foram realizados para $\mathrm{OA}$ do joelho e, 25 já estão assinalados como completos. lijima et al. ${ }^{(75)}$ realizaram uma meta análise de 35 publicações elegíveis $(n=2385$ pacientes, idade: $36,5-74,5$ anos) que realizaram transplante de CTMs em joelhos com OA. Os resultados se mostraram positivos para redução da dor, função física autodeclarada e qualidade da cartilagem. Porém, não houve aumento da espessura da cartilagem e o número de eventos adversos (dor e inchaço no joelho) variou bastante entre estudos (2-60\%). Assim como o caso para modelos animais, o nível de evidência ficou entre baixo e muito baixo, dificultando a fundamentação científica da eficácia deste tipo de tratamento.

Ainda não existe um consenso sobre a quantidade correta de células a serem implantadas e o número de transplantes necessários. Alguns estudos utilizaram $1 \times 10^{6}$ células, ${ }^{(75)}$ enquanto outros o fizeram, até $150 \times 10^{6}$, sem qualquer individualização entre pacientes, considerando que esses números equivalem, aproximadamente, a $0,015 \times 10^{6}$ células $/ \mathrm{kg}$ e $2,3 \times 10^{6}$ células $/ \mathrm{kg}$, respectivamente, para um paciente de $65 \mathrm{~kg}$ de peso corporal.

O mesmo ocorre com estudos em modelos animais. A variabilidade do número celular é grande e, em geral, desproporcional ao número de células utilizadas em humanos. Um exemplo simples são camundongos receberem até 5 $10 \times 10^{5}$ células de forma IA, o que equivaleria a uma quantia de $\approx 20-40 \times 10^{6}$ células $/ \mathrm{kg}$, 
a um camundongo C57BL/6J de oito semanas. ${ }^{(76)} \mathrm{A}$ falta de padronização do número de células prejudica a interpretação dos dados e também a translação da informação para a clínica. ${ }^{(69)}$

Outro ponto, pouco discutido, encontra-se na via de acesso do transplante, pois, praticamente, todos os estudos clínicos utilizam a via IA. O uso da via intravenosa (IV) para o transplante de CTMs já consiste objeto de estudo em outras doenças. Le Blanc et al. ${ }^{(77)}$ mostraram, em um caso clínico de doença do enxerto versus hospedeiro (GVHD) severa, que o transplante de $2 \times 10^{6}$ células $/ \mathrm{kg}$ halogênicas (células da mãe) teve um importante papel imunossupressor, melhorando o quadro e evitando o óbito do paciente.Também Le Blanc et al., ${ }^{(78)} \mathrm{em}$ um estudo multicêntrico prospectivo de fase II, observaram que, dentre 55 pacientes com GVHD, 30 responderam ao tratamento com CTMs. Dentre os pacientes responsivos, $53 \%$ apresentaram sobrevida acima de dois anos após transplante, comparados a $16 \%$ dos pacientes não responsivos.

A partir desses estudos, outros começaram a testar o efeito sistêmico de tais células em modelos animais de artrite reumatoide. ${ }^{(79-81)}$ Esses modelos são causados por administração de toxinas, promotoras de um quadro exacerbado inflamatório na articulação alvo, promovendo degeneração da cartilagem. Interessantemente, as CTMs encontram-se capazes de reduzir o quadro inflamatório, o inchaço da articulação afetada, sinais de dor e reduzir a degeneração da CA. Nesses modelos, as células são capazes de identificar e se direcionarem ao local da lesão. Tal habilidade das CTMs de identificar e migrar para locais de lesão denomina-se de homing celular.

Investigando esse potencial de homing das CTMs, quando transplantadas sistemicamente, observa-se que a barreira pulmonar causada pela diferença de tamanho entre as células e os capilares alveolares constitui um grande limitador dessa intervenção. ${ }^{\left({ }^{82}\right)}$ Grande parte das células ficam presas no pulmão, uma pequena porção consegue, de fato, chegar ao local da lesão. Por outro lado, essa primeira barreira, indiretamente, gera uma resposta sistêmica elevada de IL-10, uma citocina anti-inflamatória importante, juntamente com o efeito imunossupressor dessas células dá início ao tratamento da lesão em questão. ${ }^{(83,84)}$ Outros estudos confirmaram a eficiência das CTMs em realizar o homing após injeção IV, juntamente com a melhora do quadro clínico em diversos modelos animais diferentes, como ferimentos de pele, ${ }^{\left({ }^{(5)}\right.}$ infarto agudo do miocárdio, ${ }^{(86)}$ acidente vascular cerebral, ${ }^{(87)}$ doença do enxerto contra 
hospedeiro, ${ }^{(88)}$ atrofia muscular, ${ }^{(89)}$ tumores, ${ }^{(90)}$ lesão renal, ${ }^{(91)}$ fratura óssea ${ }^{(92)}$ e diabetes. $^{(91)}$

A dúvida em relação a utilização do transplante IV, no tratamento de $O A$ encontra-se no fato de que, apesar de ser possível avaliar, no líquido sinovial citocinas e quimiocinas como IL-1 $1 \beta$ e stromal cell-derived factor 1 (SDF-1), não se sabe ao certo se esses subprodutos da articulação osteoartrítica chegam a níveis suficientes no sistema circulatório, a ponto de promover a ação desejada das CTMs. ${ }^{(93)}$

Algumas estruturas presentes nas articulações sinoviais possuem vascularização, tais como a membrana sinovial, menisco, osso subcondral e gordura de hoffa. ${ }^{(94)}$ Apesar de a cartilagem em si ser avascular, o aporte de oxigênio e de nutrientes para o interior da articulação ocorrem por via parácrina, a partir dos vasos sanguíneos dessas estruturas. De fato, já se observou que, após transplante IA, em pequeno número, as células implantadas se alojaram no menisco e na membrana sinovial, estruturas que possuem vascularização e, provavelmente, melhores condições para as CTMs se enxertarem. ${ }^{(68)}$ Dessa forma, a possível eficácia do transplante de CTMs por via IV na OA, estaria ligada ao efeito inicial imunossupressor e antiinflamatório, decorrente do estresse pulmonar gerado pelo transplante sistêmico, somada a ação dos fatores tróficos secretados pelas CTMs se e/ou que forem capazes de realizar homing e se enxertar na microvasculatura da articulação.

\subsection{Objetivos}

1. Isolar e caracterizar células-tronco mesenquimais da medula óssea de ratos Wistar Kyoto fêmeas e induzir expressão transgênica de luciferase nestas células, permitindo a localização in vivo;

2. Observar qual o direcionamento (homing) das células-tronco mesenquimais, quando transplantadas pela via intra-articular ou intravenosa no modelo animal de osteoartrose por desestabilização do menisco medial;

3. Avaliar os efeitos anti-inflamatório e regenerativo da administração local e sistêmica de células-tronco mesenquimais, à articulação osteoartrítica e à cartilagem articular. 


\section{MÉTODOS}

\subsection{Células-tronco mesenquimais de rato}

\subsubsection{Isolamento}

As células foram isoladas, a partir da medula óssea do fêmur e tíbia de ratos Wistar Kyoto (isogênicos), fêmeas, com idade entre quatro a oito semanas (Figura 1). ${ }^{(95-97)}$

Após eutanásia (Item 2.2), os membros inferiores foram banhados com álcool 70\%, antes de serem removidos para aquisição e limpeza dos ossos. Para fins de transporte e posterior processamento, os ossos foram mantidos em tubos com salina tamponada com fosfato [1x] (PBS) (Sigma-Adrich $\left.{ }^{\circledR}\right)$ em recipiente com gelo.

Dentro de um fluxo laminar próprio para cultura celular e utilizando material estéril, a extremidade proximal do fêmur e a extremidade distal da tíbia foram cortadas e colocadas, individualmente, dentro de ponteiras de pipeta de $1 \mathrm{~mL}$, com a região cortada voltada para baixo, próxima a extremidade da ponteira. As ponteiras, contendo os ossos, foram colocadas também, individualmente, dentro de tubos de $15 \mathrm{~mL}$ e centrifugadas ( $500 \mathrm{~g} \times 3$ minutos). Assim sendo, todo o conteúdo medular foi extraído do osso para o tubo de $15 \mathrm{~mL}$, separados pela ponteira. A medula restante na ponteira foi expelida para o tubo, com auxílio de uma pipeta encaixada na ponteira. Após adição de $500 \mu \mathrm{L}$ de PBS (Sigma-Adrich ${ }^{\circledR}$ ) gelada ao tubo e homogeneização, possíveis resíduos de tecido conjuntivo foram removidos. O conteúdo extraído dos ossos foi adicionado em um único tubo de $15 \mathrm{~mL}$. Então, as hemácias foram removidas com adição (volume/volume) de solução $155 \mathrm{mM} \mathrm{NH}_{4} \mathrm{Cl}, 12 \mathrm{mM} \mathrm{NaHCO}_{3}$ e 0,1mM ácido Etilenodiamino tetra-acético (EDTA) com incubação de 5 minutos. A amostra foi centrifugada ( $500 \mathrm{~g}$ x 5 minutos) e o sobrenadante descartado. Tal procedimento de lavagem foi realizado, mais duas vezes, utilizando PBS gelado (mesmo volume anterior) para ressuspender as células. Após as lavagens, as células foram resuspensas em meio essencial mínimo de Eagle com modificação a (a-MEM) $\left(\right.$ Gibco $^{\circledR}$ ), suplementado com $20 \%$ soro fetal bovino (SFB) (Gibco ${ }^{\circledR}$ ), $1 \%$ penicilinaestreptavidina $\left(\right.$ Gibco $\left.^{\circledR}\right)$, 1\% L-glutamina (Gibco ${ }^{\circledR}$ ) e semeadas em frascos de cultura. No dia seguinte, as células foram lavadas três vezes com PBS, para eliminar células 
não aderentes (Passagem zero - P0). Os processos seguintes de cultivo e passagem (ex.: Passagem um - P1; Passagem 2 - P2) celular (Item 2.1.2) e a afinidade por aderência ao plástico terminaram de eliminar células hematopoiéticas e isolar as CTMs. O soro foi reduzido para $10 \%$, a partir da quinta passagem para reduzir a velocidade da duplicação da população celular.

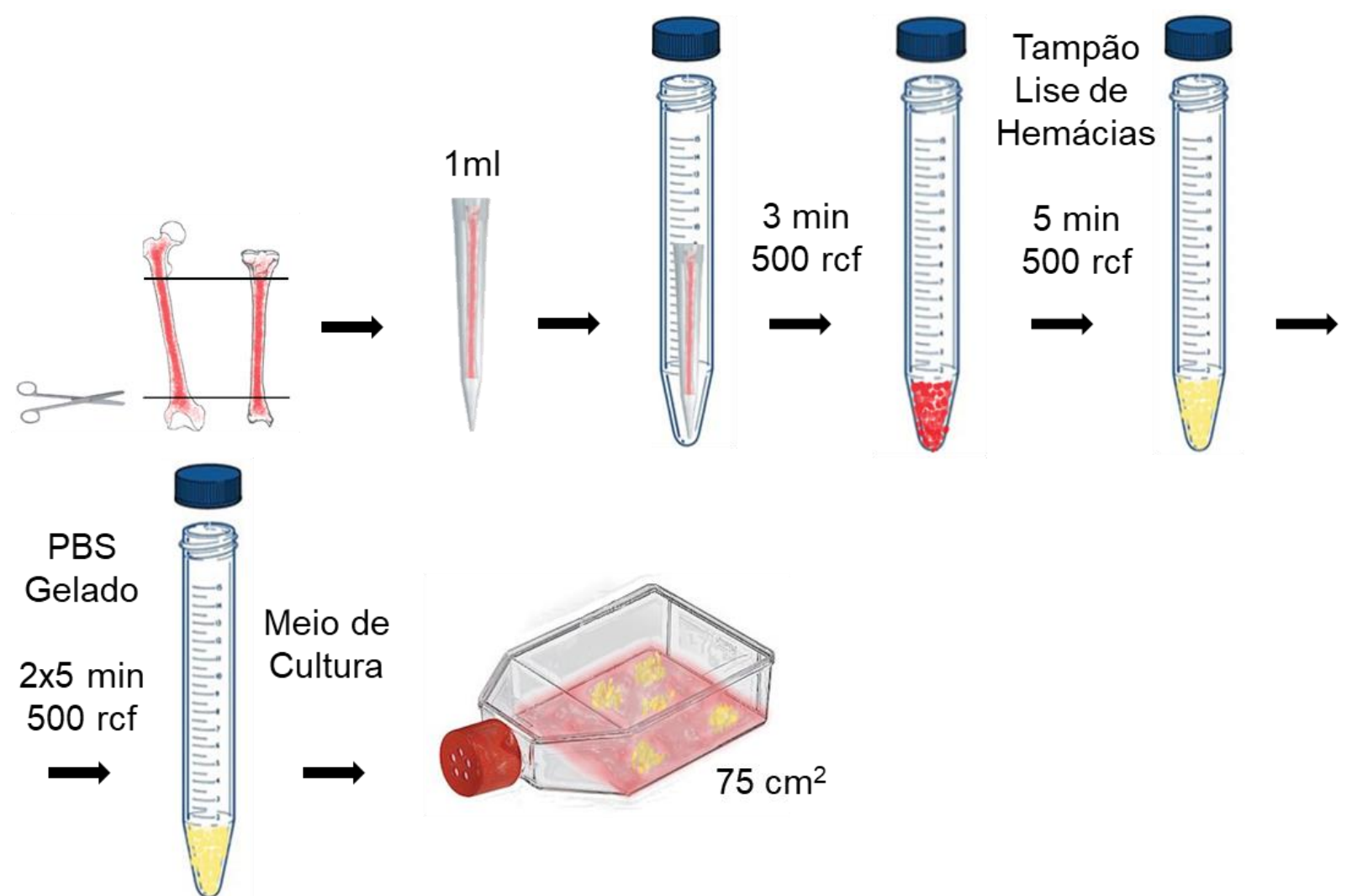

Figura 1. Etapas da extração e processamento da medula óssea para isolamento de células-tronco mesenquimais

\subsubsection{Cultivo celular}

As células foram mantidas em estufas a $37^{\circ} \mathrm{C}$ e $5 \%$ de $\mathrm{CO}_{2}$. O meio de cultura foi trocado, a cada dois dias. Ao atingirem a confluência $\geq 80 \%$, as células foram removidas do frasco de cultura com a utilização de solução de tripsina $25 \%$ e EDTA $0,05 \mathrm{mM}\left(\right.$ Gibco $\left.^{\circledR}\right)$ ou por enzimas de dissociação de células (TrypLE-Gibco ${ }^{\circledR}$ ), bem como semeadas em novos frascos de $25 \mathrm{~cm}^{2}$ com a concentração de $5 \times 10^{3}$ células $/ \mathrm{cm}^{2}$.

Em cada passagem, o excedente de células foi congelado em meio de congelamento composto por Dimetilsulfóxido (DMSO) $5 \%\left(\right.$ Sigma $\left.^{\circledR}\right)$ e 95\% SFB, na 
concentração de $5 \times 10^{5}$ células $/ \mathrm{mL}$, utilizando criotubos de $2 \mathrm{~mL}$ e cada vial contendo $1 \mathrm{~mL}$ da suspensão de células. Esses foram colocados em recipiente com isopropanol (Mr. Frosty - Thermo Fisher $\left.{ }^{\circledR}\right)$, para congelamento controlado $\left(-1^{\circ} \mathrm{C} / \mathrm{min}\right)$, armazenados diretamente em freezer $-80^{\circ} \mathrm{C}$. Vials, que não seriam utilizados, foram transferidos ao tanque de nitrogênio líquido $\left(-195^{\circ} \mathrm{C}\right)$. Para o descongelamento, os vials foram transportados em nitrogênio líquido e colocados, diretamente, em banho líquido a $37^{\circ} \mathrm{C}$. Com o início do descongelamento, o conteúdo foi rapidamente homogeneizado e adicionado em meio de cultura para inativar o DMSO. Em seguida, as células foram centrifugadas, sobrenadante descartado, resuspensas em meio de cultura, contadas e semeadas em garrafas de $75 \mathrm{~cm}^{2}$. Realizou-se a contagem das células por Câmara de Neubauer, e a viabilidade celular utilizando o corante Trypan Blue.

\subsubsection{Transdução viral}

Após a quinta passagem, as células foram expostas a partículas virais, contendo vetor de expressão para luciferas e proteína fluorescente vermelha (PFV) e cassete de resistência à puromocina LVP440-200 $\mu$ L $\left(A M S B I O{ }^{\circledR}\right.$ ). Devido a ineficiência dessas partículas virais, foram, então, substituídas pela RediFectRed-FlucPuromycin (CLS960002, PerkinElmer), também contendo vetor de expressão de Luciferase (Luciolaitalica), resistência a puromicina, mas sem expressão de PFV.

O procedimento de transdução celular ocorreu, de acordo com as instruções do fabricante. Foram utilizados $40 \mu \mathrm{L}$ de solução viral, correspondendo a 20 multiplicity of infection (MOI), para 50.000 células semeadas em placa de 24 poços. A concentração de puromicina, necessária para selecionar as células foi determinada, a partir de ensaio de dose resposta ("curva de toxicidade"). As células foram semeadas em placa de 96 poços e incubadas com diferentes concentrações de puromicina (0; $0,5 ; 1 ; 1,5 ; 2 ; 2,5 ; 3 \mu \mathrm{g} / \mathrm{mL})(\mathrm{n}=5)$, por 48 horas. Após isso, o meio foi descartado e as células foram incubadas com 3-(4, 5-dimethylthiazolyl-2)-2,5-diphenyltetrazolium bromide (MTT) por 4 horas, solubilizado com DMSO e leitura de absorbância (570nm).

Após tratamento de 48 horas com puromicina e as células selecionadas, foram cultivadas por meio de cultura habitual (Item 2.1.1). Após 3 passagens celulares, confirmou-se a eficiência da transdução pela atividade da superexpressão da luciferas e, por intermédio de ensaio bioluminescência (Item 2.6). 


\subsubsection{Diferenciação celular}

Após o isolamento, as células foram expandidas até, ao menos, a quinta passagem (P5) e testadas para a sua capacidade de diferenciação em linhagens mesenquimais (condrócitos, adipócitos e osteócitos) (Tabela 1). Para isso, as células foram cultivadas em meios indutores específicos (StemPro ${ }^{\circledR}$ Adipogenesis - A10070-01; Chondrogenesis - A10071-01; Osteogenesis Differentiation A10072-01; kit, Gibco/Life Technologies), seguindo o protocolo do fabricante. A tabela 1 , abaixo, detalha a concentração de células e o número de dias de diferenciação. Todas as culturas foram realizadas em placas de 24 poços, e o meio de diferenciação trocado duas a três vezes por semana.

Tabela 1.Características dos protocolos de diferenciação celular

\begin{tabular}{lccc}
\hline Diferenciação & Tipo & Densidade $/$ concentração & Dias de cultivo \\
\hline Adipogênese & Monocamada & $1 \times 10^{4}$ células $/ \mathrm{cm}^{2}$ & 14 \\
Osteogênese & Monocamada & $5 \times 10^{3}$ células $/ \mathrm{cm}^{2}$ & 14 \\
Condrogênese & Monocamada & $5 \times 10^{4}$ células $/ \mathrm{cm}^{2}$ & 21 \\
Condrogênese & Micromassa & $1,6 \times 10^{7}$ células $/ \mathrm{mL}$ & 21 \\
\hline
\end{tabular}

Posterior ao período de cultivo, com os meios de indução mesenquimais, a confirmação da diferenciação foi realizada por colorações específicas de Oil Red para adipócitos, Alcian Blue para condrócitos e Alizarin Red para osteócitos. Também, para a diferenciação em micromassas, essas foram moldadas em blocos de parafina, possibilitando cortes histológicos de $5 \mu \mathrm{m}$ e coloração com Safranina-O.

\subsubsection{Caracterização celular}

Paralelamente a diferenciação e também após a P5, as células foram analisadas, quanto à caracterização da expressão de moléculas de superfície representativas de CTMs, pela técnica de citometria de fluxo. Foi considerado como padrão expressão $\geq 95 \%$ para CD90, CD105, CD29 e CD44 e $\leq 5 \%$ para CD34, CD45 e CD11b/c.

Para tanto, alíquotas de $2,5 \times 10^{5}$ células, em $100 \mu \mathrm{L}$ de PBS, foram incubadas cada uma com um único anticorpo, conjugado de acordo com a instrução do 
fabricante. Após a incubação, as alíquotas foram centrifugadas ( 5 min $\times 500 \mathrm{~g})$, o sobrenadante descartado e as células resuspensas em $1 \mathrm{~mL}$ de PBS. Esse procedimento de lavagem se repetiu, uma vez, e então a suspensão celular foi pipetada, por meio de um filtro de $40 \mu \mathrm{m}$ para um tubo de citometria de $5 \mathrm{~mL}$. O conteúdo de cada tubo foi agitado no Vortex, previamente, a sua utilização no citômetro (BD LSRFortessa). O protocolo no citômetro foi definido para aquisição de 10000 eventos. As análises dos dados foram realizadas no software FlowJo V10.

\subsection{Animais}

Foram utilizados 150 ratos da linhagem Wistar Kyoto, fêmeas adultas jovens (idade: $6,12 \pm 1,36$ meses; peso: $243,22 \pm 11,51 \mathrm{~g}$ ), mantidos em biotério com condições ideais de temperatura, humidade, exposição ao claro e escuro (12/12h) e receberam dieta e água ad-libidum. Esse biotério, localizado no Centro de Experimentação e Treinamento em Cirurgia, pertence ao Instituto Israelita de Ensino e Pesquisa Albert Einstein e possui acreditação da "Association for Assessment and Accreditation of Laboratory Animal Care (AAALAC)", devido ao padrão de conduta ética e a qualidade da experimentação, condições de segurança de funcionários, bem como de pesquisadores envolvidos, além de instalações e equipamentos. Após o período experimental, os animais foram submetidos à eutanásia, realizada por intermédio de sedação, por inalação de isoflurano e subsequente asfixia por inalação de $\mathrm{CO}^{2}$ ou overdose anestésica com Ketamina e Xilazina.

Os protocolos de manuseio, procedimentos e eutanásia dos animais assim como o projeto, foram aprovados pelo Comitê de Ética em Experimentação e Uso Animal (CEUA) do Hospital Israelita Albert Einstein (HIAE) sob número 2275-15.

\subsubsection{Modelo de osteoartrose}

O modelo de OA ocorreu, por meio de um procedimento cirúrgico de desestabilização do menisco medial (DMM) do joelho direito de cada animal. ${ }^{(98)} \mathrm{Tal}$ procedimento consiste na transecção do ligamento meniscotibial medial (Figura 2), gerando instabilidade na articulação do joelho do animal. A cirurgia se iniciou com uma 
incisão (bisturi lâmina 15) da pele sobre a região distal da patela até o platô tibial, expondo a cápsula articular. Em seguida, uma incisão (bisturi lâmina 15), imediatamente medial ao ligamento patelar, foi realizada, expondo a articulação. Após deslocar a patela lateralmente, e dissecar (Jewelers fórceps) o tecido adiposo infrapatelar, tornou-se possível observar o ligamento meniscotibial medial (LMTM). Após a secção (bisturi lâmina 11) do LMTM, reposicionou-se a patela, e a cápsula articular e a pele foram suturadas, com fio absorvível de poliglactina 6-0 (VicrylEthicon ${ }^{\circledR}$ ) e prolipropileno 5-0 (Prolene-Ethicon ${ }^{\circledR}$ ), respectivamente. Sabe-se que, nove semanas, após o procedimento cirúrgico DMM, ocorre a instalação da $O A$, caracterizada pela lesão focal na região do platô tibial medial (PTM) e no côndilo medial do fêmur (CMF).

No caso do grupo controle com intervenção cirúrgica falsa (SHAM), exatamente os mesmos procedimentos e etapas da cirurgia DMM foram realizadas, porém, após observar o LMTM, a patela foi reposicionada e a cápsula articular e a pele suturadas sem realizar a transecção do LMTM. Diferente dos animais que passaram por DMM, o procedimento cirúrgico SHAM não deve gerar lesão da cartilagem no PTM e CMF.

Durante a cirurgia, sedou-se o animal, utilizando-se de um equipamento de anestesia inalatória (SomnoSuite - Kent Scientific ${ }^{\circledR}$ ) com máscara anestésica, mantido sobre uma manta térmica a $38^{\circ} \mathrm{C}$ (PhysiosuiteRightTemp - Kent Scientific ${ }^{\circledR}$ ), fluxo contínuo de ar e isoflurano 2-3\% (Isoforine - Cristália $^{\circledR}$ ). Antes do procedimento de sedação do animal, utilizou-se isoflurano $5 \%$, e um protocolo de analgesia prévia de Tramal $10 \mathrm{mg} / \mathrm{mL}$ + Dipirona $200 \mathrm{mg} / \mathrm{mL}$ foi aplicada a $1,5 \mu \mathrm{L} / \mathrm{g}$ de peso do animal de forma intraperitoneal. Todos os procedimentos de assepsia necessários foram realizados, previamente, à cirurgia. A analgesia e o acompanhamento pós-cirúrgico foram realizados, nas primeiras 72 horas. Observados sinais de dor pela "escala facial de dor", ${ }^{(99)}$ foi aplicado o seguinte protocolo analgésico:

-Dor leve $(0,25 \leq$ dor $<1): 0,25 \mu \mathrm{L} / \mathrm{g}^{*}$ de animal-intramuscular; ou $100 \mathrm{mg}$ de dipirona em $500 \mu \mathrm{L}$ de gelatina;

-Dor moderada $(1 \leq \mathrm{dor}<1,5): 0,5 \mu \mathrm{L} / \mathrm{g}^{*}$ de animal-intraperitoneal;

-Dor severa (dor $\geq 1,5$ ): $1,0 \mu \mathrm{L} / \mathrm{g}^{*}$ de animal-intraperitoneal;

-Procedimento cirúrgico: $1,5 \mu \mathrm{L} / \mathrm{g}^{*}$ de anima-intraperitoneal;

*Solução analgésica: Cloridrato de Tramadol $10 \mathrm{mg} / \mathrm{mL}$ + Dipirona $200 \mathrm{mg} / \mathrm{mL}$. 
Os dados foram registrados em prontuário aprovado pelo CEUA

(Anexo 1).

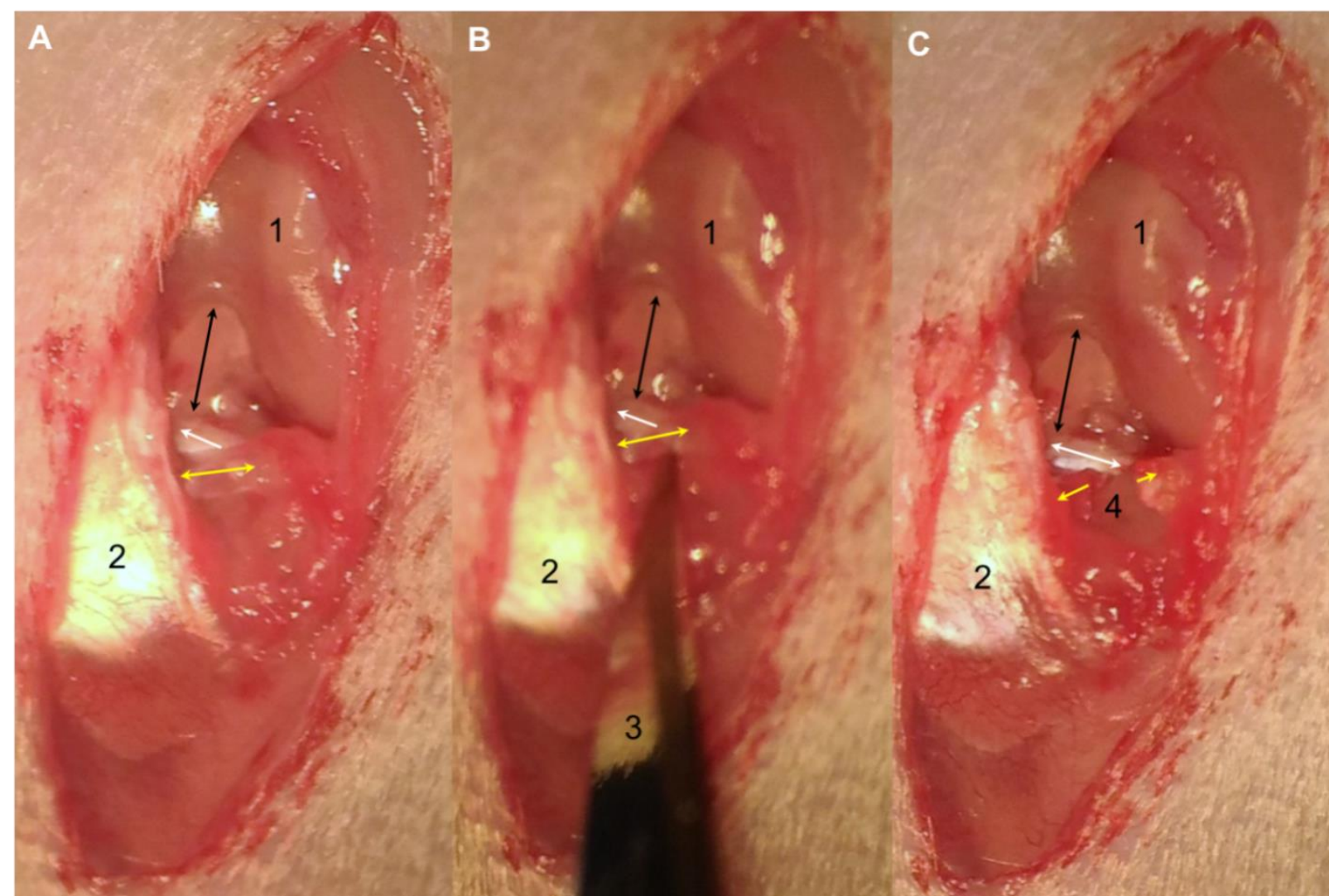

Seta amarela: LMTM: Ligamento menisco tibial medial; Seta branca: Ligamento menisco tibial lateral; Seta preta: Ligamento cruzado anterior. 1: Cartilagem articular do epicôndilo do fêmur; 2: Ligamento patelar; 3: Bisturi número 11; 4: Platô medial da tíbia. (A) Articulação aberta e patela deslocada lateralmente; (B) Posicionamento do bisturi para transecção do LMTM. (C) Transeção do LMTM e exposição do platô medial da tíbia.

Figura 2. Procedimento cirúrgico de desestabilização do menisco medial

\subsection{Transplante celular e placebo}

Após o tempo necessário ao desenvolvimento da OA (9 semanas) por DMM ou igualmente o mesmo tempo de espera para os grupos com cirurgia SHAM, os animais foram separados, aleatoriamente, em grupos (4.4.1) e receberam injeção contendo CTMs ou PLACEBO como transplante intravenoso (IVt) ou transplante intraarticular (IAt). 


\subsubsection{Transplante intravenoso}

O animal foi inicialmente sedado com [5\%] de Isoflurano e mantido com anestesia inalatória superficial [1.5-2.5\%] de Isoflurano. Com o animal em decúbito lateral, a calda foi envolta por uma manta térmica a $42^{\circ} \mathrm{C}$ (PhysioSuite RightTemp Kent Scientific ${ }^{\circledR}$ ) durante um minuto (Figura 3). Utilizando um cateter de 24G, a veia caudal lateral foi acessada. Um tubo extensor, conectado a um injetor de seringa digital $\left(\right.$ KDS210 - KD Scientific $\left.^{\circledR}\right)$, foi previamente preenchido com a suspensão a ser administrada. Após o preenchimento do cateter com sangue, houve a conexão ao tubo extensor, injetando-se o conteúdo com velocidade constante de $500 \mu \mathrm{L} /$ minuto.

Administrou-se a suspensão contendo CTMs, de forma sistêmica, por uma única injeção na veia caudal, contendo $2 \times 10^{6} / \mathrm{kg}$ células em $1 \mathrm{~mL}$ de PBS. Aos grupos com administração placebo utilizou-se a mesma forma de transplante e volume de PBS, sem adição de células. O volume da suspenção e concentração de células, foram adequados para que o animal recebesse, exatamente, a quantidade proposta, sem redução pelo volume morto do cateter ou da agulha utilizada ao aspirar a suspensão para o tubo extensor.

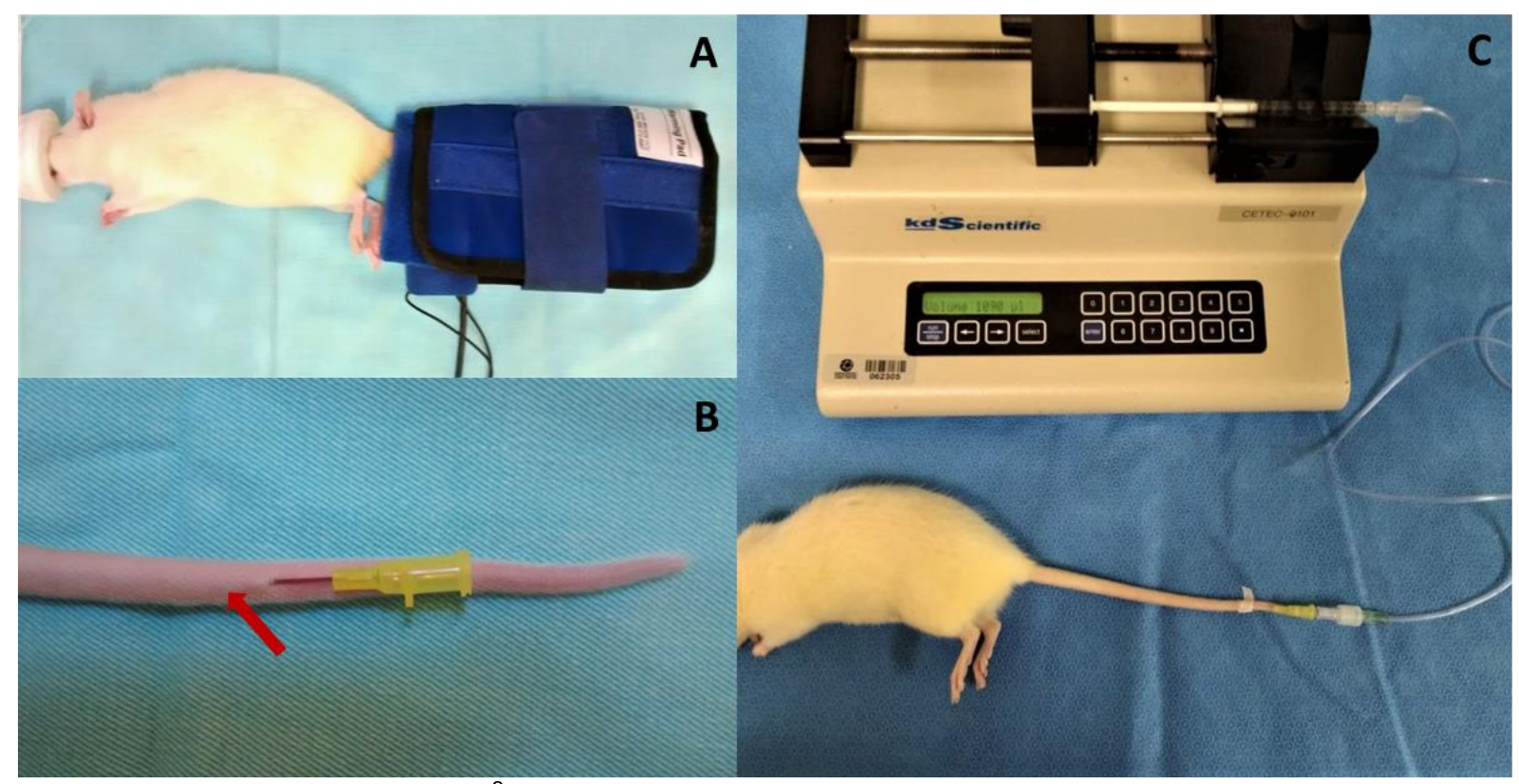

(A) Aquecimento da calda a $42{ }^{\circ} \mathrm{C}$; (B) Introdução do cateter 24G na veia caudal (seta vermelha); (C) Injetor de seringa conectado ao cateter para administração de $1 \mathrm{~mL}$ de suspenção com ou sem células.

Figura 3. Transplante intravenoso 


\subsubsection{Transplante intra-articular}

Inicialmente, sedou-se animal com [5\%] de Isoflurano, mantendo-o com anestesia inalatória [2-3\%] de Isoflurano. Em decúbito dorsal, o membro inferior (MI) direito foi semiflexionado e apoiado sobre um tubo de $15 \mathrm{~mL}$, posicionado na região posterior do joelho, com o intuito de estabilizar a posição do membro. A injeção IA foi realizada, medialmente, ao ligamento patelar e, perpendicularmente, proximal ao PTM e ao CMF (Figura 4), utilizando-se uma seringa de 0,3mL (BD - Ultrafine ${ }^{\circledR}$ ).

A suspensão de CTMs foi administrada de forma local por uma única injeção IA contendo $2 \times 10^{6} / \mathrm{kg}$ células em $50 \mu \mathrm{L}$ de PBS; aos grupos com administração placebo utilizou-se a mesma forma de transplante e volume de PBS, sem adição de células.

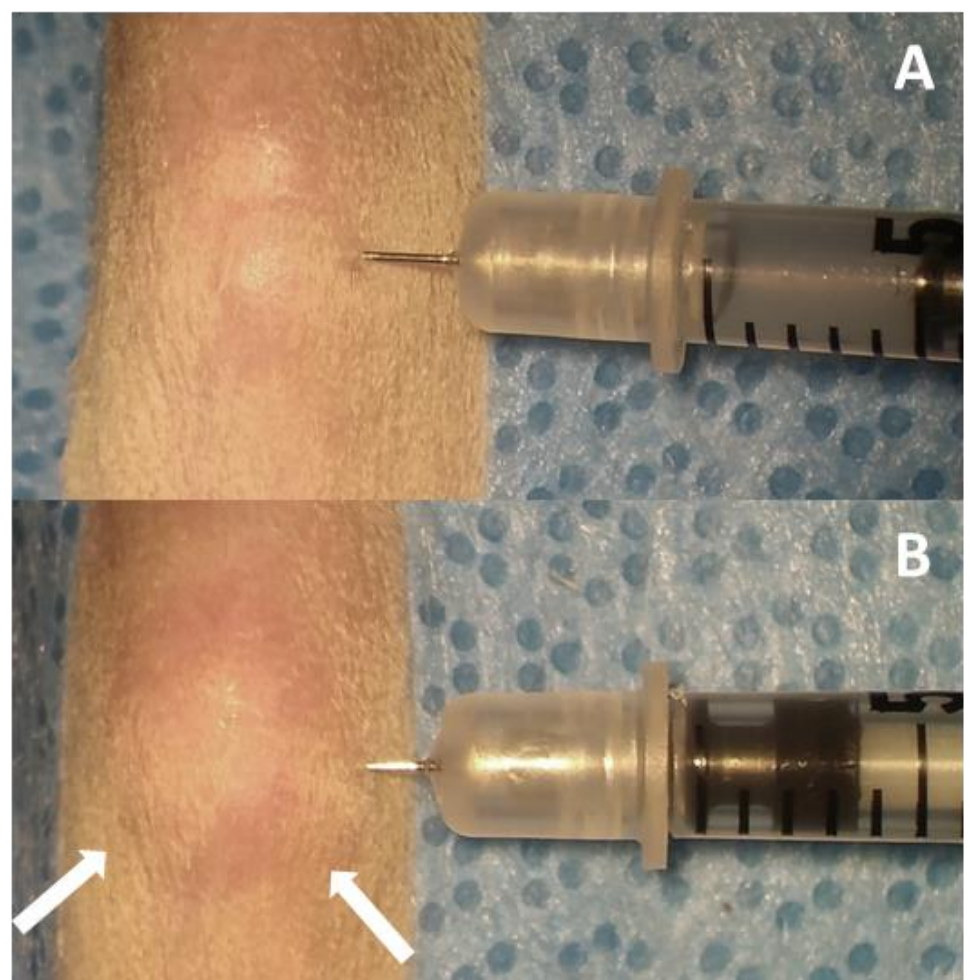

(A) Inserção da seringa medialmente ao ligamento patelar. (B) Após aplicação de $50 \mu \mathrm{L} / \mathrm{mL}$ de suspenção com ou sem células. Setas brancas indicam a dilatação da cápsula articular, devido ao volume do transplante.

Figura 4. Transplante intra-articular 


\subsection{Design Estudo agudo}

Inicialmente, analisou-se a resposta inflamatória sistêmica, aguda e homing das CTMs para o joelho acometido por OA nos animais. Logo após o transplante de células, via IV ou IA. Para tanto, nove semanas após o desenvolvimento do modelo de DMM, os animais receberam CTMs via IAt, grupo intra-articular (G-IAt) e outro grupo via IVt, grupo intravenoso (G-IVt) (Figura 5).

A análise de imagens de luminescência (Item2.6.2) para localização corporal das células (G-IAt: N=6; G-IVt: N=6) foi realizada nos períodos de duas, oito, 24 horas e também uma semana. Após a última análise, os animais foram eutanasiados, com o rim, fígado, pulmão, pâncreas, quadríceps femoral e articulação do joelho coletados para processamento histológico.

Com a finalidade de obtenção da resposta inflamatória sistêmica, realizaram-se coletas de sangue para análise (G-IAt: N=6; G-IVt: N=6), no momento anterior (entre 24 a 72 horas) ao transplante (Pós-DMM) e duas horas $(2 \mathrm{H}), 24$ horas (24H) e 1 semana (1S) (Figuras 5 e 7). Os animais da coleta de sangue foram randomicamente selecionados, entre os animais dos grupos DMM+CTM-IAt-4S e DMM+CTM-IVt-4S (Item 2.5 para nomenclatura de grupo), assim como tiveram o ponto de duas e 24 horas adicionados à linha do tempo de coletas de sangue (Figura 7). Após a coleta de uma semana, esses animais continuaram o protocolo dos respectivos grupos até a eutanásia.

Complementar a análise in vivo, alguns animais (G-IVt: $\mathrm{N}=4$ ) receberam células marcadas fluorescentes (Item 2.7.1). Após 12 horas do transplante, realizou-se a eutanásia, coletando-se o pulmão e a articulação do joelho desses animais. Esse material foi digerido e processado para análise de citometria por imagem e microscopia confocal.

Descrição dos grupos:

1. Grupo com transplante celular intravenoso (G-IVt; Imagem: $N=6$; Sangue: $\mathrm{N}=6$; Citometria por imagem: $\mathrm{N}=3$; Confocal: $\mathrm{N}=1$ );

2. Grupo com transplante celular intra-articular (G-IAt; Imagem: N=6;

Sangue: $\mathrm{N}=6$ ). 


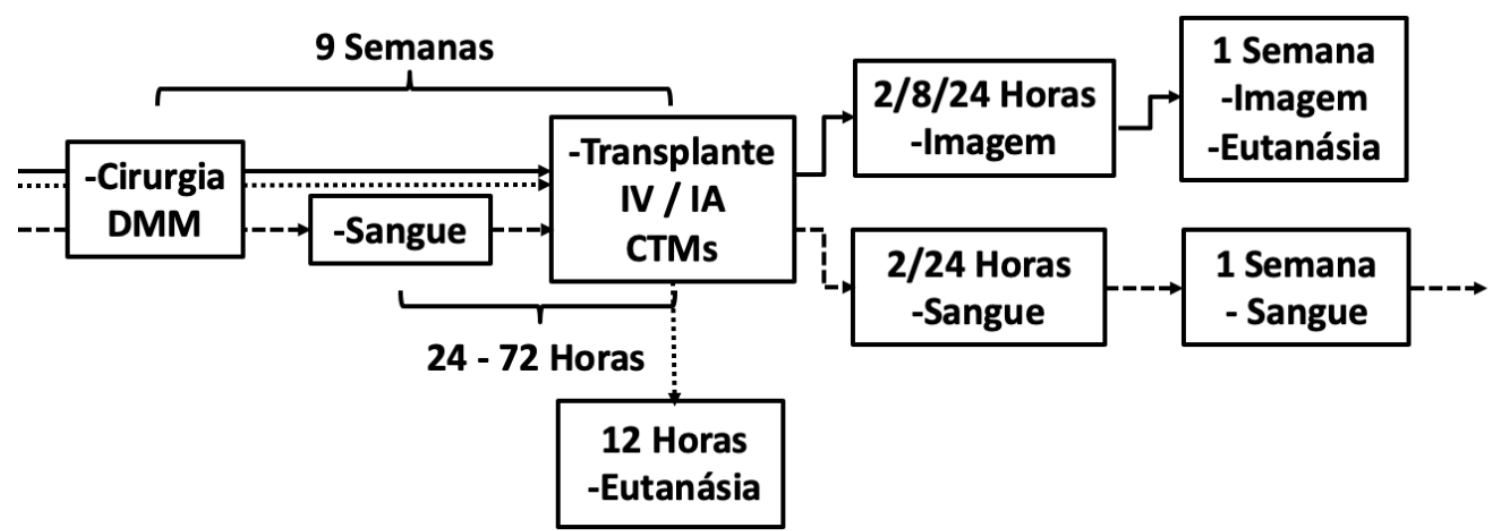

Ordem cronológica e o tipo de coleta realizada; IV:Intravascular; IA: Intra-articular. Setas contínuas indicam a ordem de eventos aos animais do experimento de luminescência; setas tracejadas indicam a ordem aos que fizeram coleta de sangue para análise de perfil inflamatório; seta pontilhada indica adem aos animais coletados para análise de citometria, por imagem e confocal. Chaves indicam tempo decorrido entre eventos.

Figura 5. Fluxograma do delineamento experimental agudo

\subsection{Design Estudo longitudinal}

Realizou-se um estudo longitudinal, a fim de avaliar o potencial regenerativo das CTMs transplantadas via IV ou IA, na degeneração da CA do modelo de OA por DMM, após nove semanas da cirurgia (Figura 6). Além da diferença entre vias de transplante, avaliou-se o efeito dos transplantes, ao longo do tempo, utilizando pontos distintos de eutanásia. Seis grupos foram eutanasiados, quatro semanas após o transplante (4S) e mais seis grupos, 12 semanas após o transplante (12S). Os grupos $12 S$ realizaram os mesmos procedimentos que os $4 \mathrm{~S}$, porém foram mantidos por mais oito semanas até a eutanásia. A nomenclatura dos grupos segue a seguinte estrutura:

- Tipo de cirurgia + Tipo de transplante - Via de transplante - Tempo de eutanásia;

Durante a descrição e discussão de resultados, os itens desta nomenclatura foram utilizados de forma completa, individual ou parcialmente juntos, de acordo com a necessidade descritiva do conteúdo em questão. Porém, sempre seguindo os mesmos termos;

- Descrição dos grupos experimentais:

1. Grupos com intervenção cirúrgica SHAM e transplante celular intravenoso: (SHAM+CTM-IVt-4S, N=10; SHAM+CTM-IVt-12S, N=10);

2. Grupos com intervenção cirúrgica SHAM e transplante celular intra-articular: (SHAM+CTM-IAt-4S, N=10; SHAM+CTM-IAt-12S, N=10); 
3. Grupos com $\mathrm{OA}$, desenvolvida por cirurgia DMM e transplante placebo intravenoso: (DMM+PLACEBO-IVt-4S, N=10; DMM+PLACEBO-IVt-12S, $\mathrm{N}=10$ ). Como os animais desse grupo não receberam células, por nenhuma via de transplante ou injeção intra-articular, eles foram utilizados como controle (CON) à análise de peso muscular (Item 2.13), de acordo com o tempo decorrido após cirurgia (nove semanas) até a eutanásia (quatro ou 12 semanas), ou seja, 13 semanas (13S) e 21 semanas $(21 \mathrm{~S})$;

4. Grupos com OA, desenvolvida por cirurgia DMM e transplante placebo intra-articular: (DMM+PLACEBO-IAt-4S, N=10; DMM+PLACEBO-IAt-12S, $\mathrm{N}=10$ );

5. Grupos com OA, desenvolvida por cirurgia DMM e transplante celular intravenoso: (DMM+CTM-IVt-4S, N=10; DMM+CTM-IVt-12S, N=10);

6. Grupos com OA, desenvolvida, após, por cirurgia de DMM etransplante celularintra-articular: (DMM+CTM-IAt-4S, N=10; DMM+CTM-IAt-12S, $\mathrm{N}=10$ ).

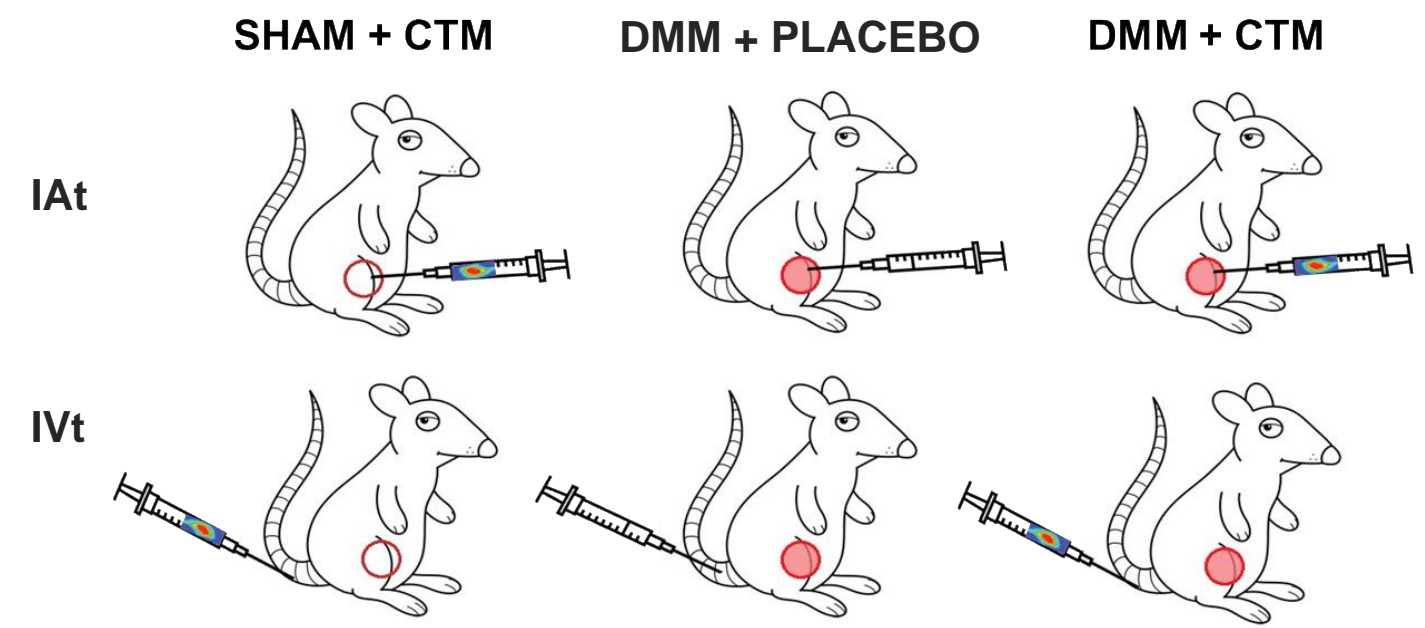

Círculos vermelhos preenchidos representam a intervenção cirúrgica com desestabilização do menisco medial e os círculos vazios a intervenção cirúrgica sem desestabilização. As seringas coloridas representam transplante de células que expressam luciferase e a seringa sem cor representa o transplante, apenas do meio de suspensão, sem adição de células.

Figura 6. llustração das intervenções experimentais

As coletas de sangue ocorreram, entre 24 a 72 horas, antes da cirurgia (Pré-DMM), antes do transplante (Pós-DMM / Pós-SHAM) e eutanásia (4S e 12S). Também houve uma coleta, uma semana após o transplante (1S). As coletas de marcha ocorreram sempre, depois das coletas de sangue, dentro do mesmo período. Amostras de lavado sinovial (LS) foram obtidas, no mesmo dia, porém antes do 
procedimento cirúrgico ou eutanásia. As coletas de sangue de duas e 24 horas. Após transplante, foram apenas de seis animais do grupo DMM+CTM-IAt-4S e de seis do grupo DMM+CTM-IVt-4S e são referentes ao estudo agudo (Item 2.4).

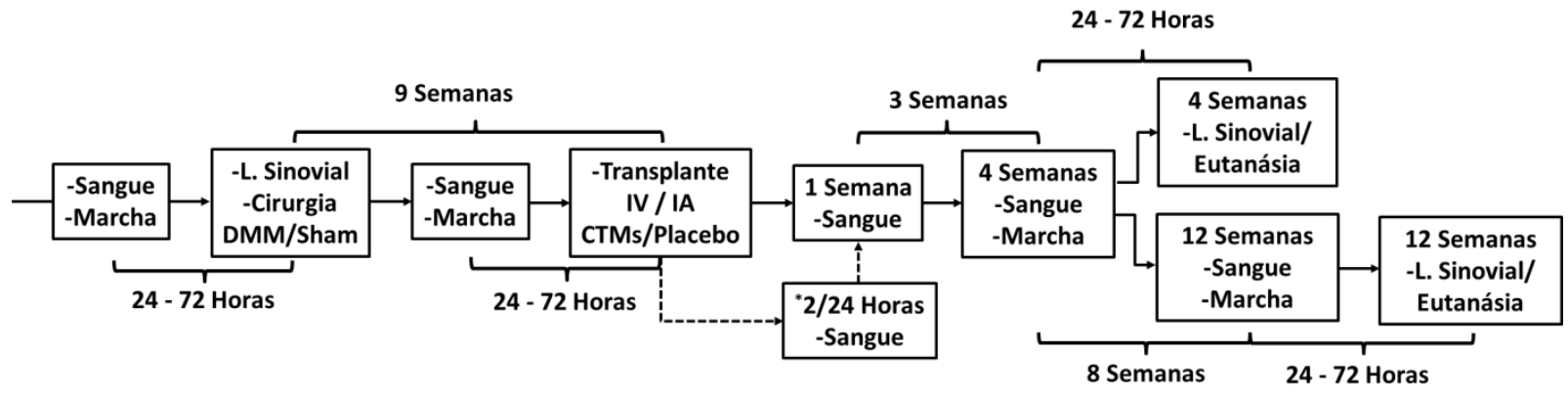

Ordem cronológica e o tipo de coleta realizada; IV: Intravascular; IA: Intra-articular. Setas pretas contínuas indicam a ordem de eventos aos animais do experimento longitudinal, e as setas pretas pontilhadas, dos animais que fizeram coleta de sangue a mais ao estudo transversal. Chaves indicam tempo decorrido entre eventos.

Figura 7. Fluxograma do delineamento experimental longitudinal

\subsection{Luminescência in vitro e in vivo}

A eficiência da transdução viral e o rastreamento das células transplantadas nos animais ocorreram com o sistema de aquisição de imagem, por intermédio da reação de bioluminescência (luciferase/D-luciferina), gerada pelas CTMs expressando luciferase.

A quantificação da leitura da luminescência in vitro ocorreu no leitor de microplacas Spectramax M5 (Molecular Devices ${ }^{\circledR}$ ), utilizando-se de um comprimento de onda de $570 \mathrm{~nm}$ para leitura do sinal.

Todos os experimentos de imagem in vivo de luminescência utilizaram o sistema de imagens IN-VIVO MSFX PRO (Carestream ${ }^{\circledR}$ ) e o software de análise Molecular Imaging Software 7.5 (Bruker $\left.^{\circledR}\right)$. Capturou-se 0 sinal de luminescência, utilizando agrupamento de sinais adjacentes "binning" de oito vezes, quando necessário.

Para análise, considerou-se o valor de pico de fótons/segundo $/ \mathrm{mm}^{2}$ de cada imagem. Todas as imagens foram sobrepostas a radiografias, obtidas pelo mesmo sistema (Item 2.8). 
Além dos ensaios de luminescência, outra estratégia utilizada para localização das células transplantadas nos órgãos ou tecidos da articulação do joelho, foi a identificação destas por meio de imuno-histoquímica (Item 2.11.5).

\subsubsection{In vitro}

As CTMs foram semeadas, em placas de 24 poços, em diferentes concentrações $\left(20 \times 10^{3} ; 10 \times 10^{3} ; 5 \times 10^{3} ; 2,5 \times 10^{3} ; 1,25 \times 10^{3}\right)$ e cultivadas por 24 horas. Também foram semeadas CTMs, sem expressão de luciferase, nas mesmas condições ao controle de background da reação de luminescência.

Para iniciar a reação de luminescência, adicionou-se $1 \mathrm{mM}$ $(150 \mu \mathrm{g} / \mathrm{mL})$ de luciferina (D-Luciferin - Sigma-Aldrich), ao meio de cultura em cada passo, detectando-se a luminescência no leitor de placa, imediatamente, após adição. Em seguida, colocou-se essa mesma placa no aparelho de captura de imagens in vivo. Após 10 minutos da adição de luciferina, ocorreu a aquisição da imagem de luminescência com exposição de 3 minutos e sem utilização de binning.

\subsubsection{In vivo}

Utilizou-se a bioluminescência, com a finalidade de rastrear as CTMs no corpo do animal, após o transplante IA ou IV. Os pontos de coleta encontram-se descritos na figura 5 . Os animais foram sedados com isoflurano $5 \%$ e mantidos com isoflurano $2 \%$, durante toda a coleta. Para dar início à reação de luminescência por ação da luciferase, injetou-se, de forma intraperitoneal, $150 \mathrm{mg} / \mathrm{kg}$ do substrato Dluciferina $30 \mathrm{mg} / \mathrm{mL}$.

Inicialmente, determinaram-se os parâmetros de aquisição ideais, que possibilitariam a obtenção do sinal de luminescência invivo, independente da via de transplante. Dessa forma, possibilitou-se avaliar a cinética da reação de luciferina/luciferase e obter a "janela temporal" com maior sinal de luminescência, gerado pelas células transplantadas. Para tanto, a captura de imagens se iniciou, após seis minutos da administração de luciferina, utilizando-se de três minutos de exposição por imagem, durante 48 minutos (16 imagens) e binning de oito vezes. 
A melhor "janela temporal" para aquisição das imagens foi determinada, a partir do tempo em que a exposição (três minutos) apresentou maior sinal de luminescência, com margem de um intervalo de exposição anterior e um posterior ao mesmo, totalizando nove minutos.

As imagens foram capturadas nos tempos descritos na figura 5 , utilizando-se a "janela temporal", de acordo com a via de transplante usada. A fim de gerar imagens comparativas, a escala de cores de cada imagem foi normalizada pela escala obtida, na imagem de maior pico de fótons/segundo/ $/ \mathrm{mm}^{2}$.

\subsection{Localização celular ex vivo}

A fim de ajudar na identificação do homing de células para o joelho, 12 horas após o transplante IV, utilizou-se das técnicas de citometria por fluxo de imagem e microscopia confocal.

\subsubsection{Marcação fluorescente}

As CTMs, usadas para esse experimento, receberam dupla marcação fluorescente de membrana celular por marcadores lipofílicos DiL e DiD $\left(\right.$ LipophilicTracers- invitrogen $\left.{ }^{\circledR}\right)$. Realizou-se a marcação, de acordo com as recomendações do fabricante.

\subsubsection{Isolamento e processamento tecidual}

Após a eutanásia, dissecou-se a articulação do joelho com DMM e foram isolados os meniscos, cartilagem do fêmur e tíbia, contendo osso subcondral e a estrutura anterior do joelho, contendo membrana sinovial, tecido adiposo de Hoffa, patela e ligamento patelar (Figura 8). Também, coletou-se o pulmão do mesmo animal.

Para microscopia confocal, os tecidos foram processados conforme descrito no "Item 2.11.2".

Para citometria por imagem, agruparam-se os tecidos da articulação, em um único tubo de $15 \mathrm{~mL}$, e o tecido pulmonar em tubo separado. Os tecidos foram 
digeridos em Colagenase tipo IA $(2 \mathrm{mg} / \mathrm{mL})$ por uma hora a $37^{\circ} \mathrm{C}$. Em seguida, o conteúdo da digestão foi passado por um filtro celular de $40 \mu \mathrm{m}$ e centrifugado $(500 \mathrm{~g} \mathrm{x}$ $5 \mathrm{~min})$. O sobrenadante foi descartado, o pellet ressuspenso em PBS $1 \mathrm{x}$ e centrifugado novamente. Esse procedimento se repetiu, porém, o pellet foi ressuspenso em $50 \mu \mathrm{L}$ de PBS $1 x$ com $2 \mu \mathrm{L}$ de EDTA e a amostra foi levada ao citômetro.

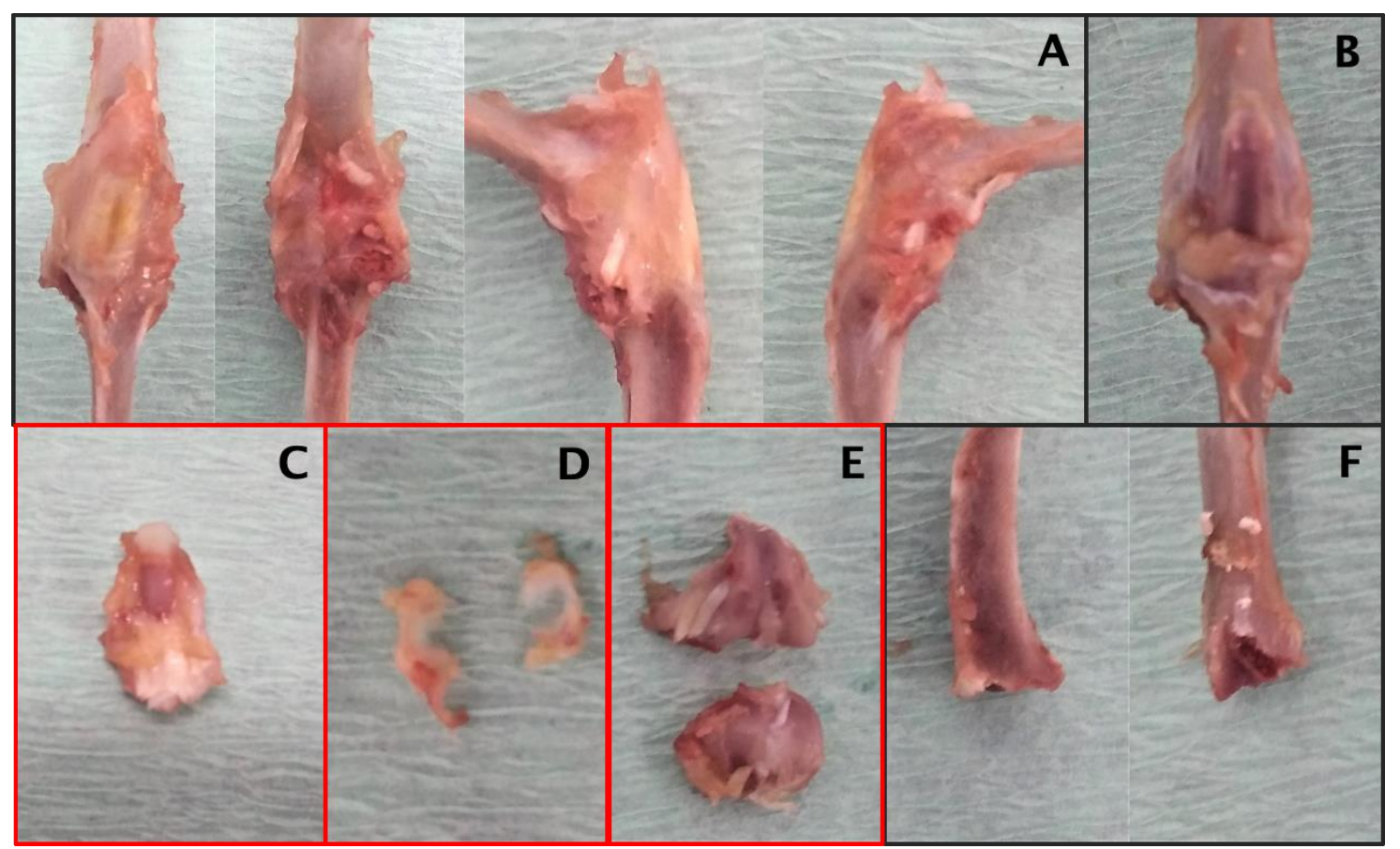

(A) Articulação do joelho dissecada; (B) e (C) Isolamento da membrana sinovial, tecido adiposo de Hoffa, patela e tendão patelar; (D) Meniscos; (E) Cartilagem do fêmur (topo) e tíbia; (F) Tíbia (esquerda) e fêmur após remoção da cartilagem.

Figura 8. Dissecação da articulação do joelho

\subsubsection{Citometria por fluxo por imagem}

O Citômetro de Fluxo por Imagem Amnis combina duas potentes tecnologias: imagens no modo widefield e citometria de fluxo. A referida tecnologia auxilia na identificação e caracterização de populações celulares raras, com maior precisão, uma vez que é possível visualizar e avaliar a imagem de cada evento, de maneira individual ou agrupando, de acordo com as características desejadas.

Os eventos foram adquiridos, utilizando a configuração padrão do software ImageStream, durante 1 hora. Todos os eventos adquiridos foram classificados em região de foco (gradiente RMS_M01 - 40 a 86), seguidos pela dispersão XY, área versus circularidade (Area_M01; 100 a $1000 \mu \mathrm{m}$ versus 
aspectratio_M01; 1 a 0,6), sendo M01 referente a máscara padrão para o canal 01 , utilizando imagens do tipo campo claro. Para a criação da matriz de compensação, as células foram marcadas com apenas um dos corantes lipofílicos DiL ou DiD e geradas automaticamente pelo software ImageStream. Tanto a análise das amostras como a aplicação da matriz de compensação realizaram-se no software IDEAS.

Após a definição das máscaras para cada canal, Ch01 - Brigthfield; Ch03 - DiL e Ch11 - DiD, gerou-se um novo "dotplot" de dispersão XY, relativo a intensidade de fluorescência $\mathrm{Y}=\mathrm{DiL}$ versus $\mathrm{X}=\mathrm{DiD}$, à delimitação de cada população, DiL+; DiD+; Sem marcação e DiL+DiD+ considerada a tronco mesenquimal.

\subsubsection{Microscopia confocal}

Com a finalidade de facilitar a identificação das estruturas teciduais contendo células marcadas, as amostras receberam marcação nuclear por DAPI (4',6Diamidino-2-Phenylindole, Dihydrochloride) (ThermoFisher ${ }^{\circledR}$ ).

Obteve-se uma imagem em aumento de 20x, utilizando o microscópio confocal ZEISS com a seguinte configuração: laser 405 (DAPI), 561(DiL) e 633(DiD); pinhole=1; bit depth=8; $x y=1024 \times 1024$ pixels. As imagens foram, posteriormente, processadas no software Fiji (Image $\mathrm{J}$ ) e obtidas imagens de 40x, utilizando a ferramenta de zoom.

Um corte histológico sequencial ao utilizado para o confocal foi corado com Hematoxilina e Eosina, a fim de ajudar a identificação da estrutura do tecido.

\subsection{Raio-X}

O aparato de Raio-X do sistema IN-VIVO MSFX PRO (Carestream ${ }^{\circledR}$ ) foi utilizado, com o intuito de realizar co-localização in vivo do corpo do animal com o sinal de luminescência (Item 2.6.2), ou seja, toda imagem de luminescência possui uma respectiva imagem radiográfica na mesma posição. Também, utilizou-se para avaliação da lesão no joelho, acometido por OA (Item 2.8.1), otimização do protocolo de descalcificação de peças histológicas (Item 2.8.2) e co-localização in vitro das células com placa de cultura no ensaio de luminescência (Item 2.6.1). 
As radiografias foram obtidas com os seguintes parâmetros: foco 0.95, plano focal 10, exposição de 2.9 segundos ao Raio-X e filtro de chumbo de $0,8 \mathrm{~mm}$. As imagens estão representadas em fótons/segundos $/ \mathrm{m}^{2}$.

\subsubsection{Avaliação da lesão}

Com o intuito de avaliar alterações ósseas na articulação do joelho, desenvolveu-se uma órtese plástica com velcro, para fixar a cintura e os membros inferiores (Figura 9) e manter os animais anestesiados na mesma posição, com $\approx 120^{\circ}$ de extensão da articulação do joelho $\left(180^{\circ}=\right.$ extensão total).

Os exames foram realizados em seis animais, de cada um dos grupos do estudo longitudinal, com imagens em decúbito dorsal e ventral. As radiografias foram analisadas de forma qualitativa, a partir de imagens do compartimento medial da articulação do joelho.

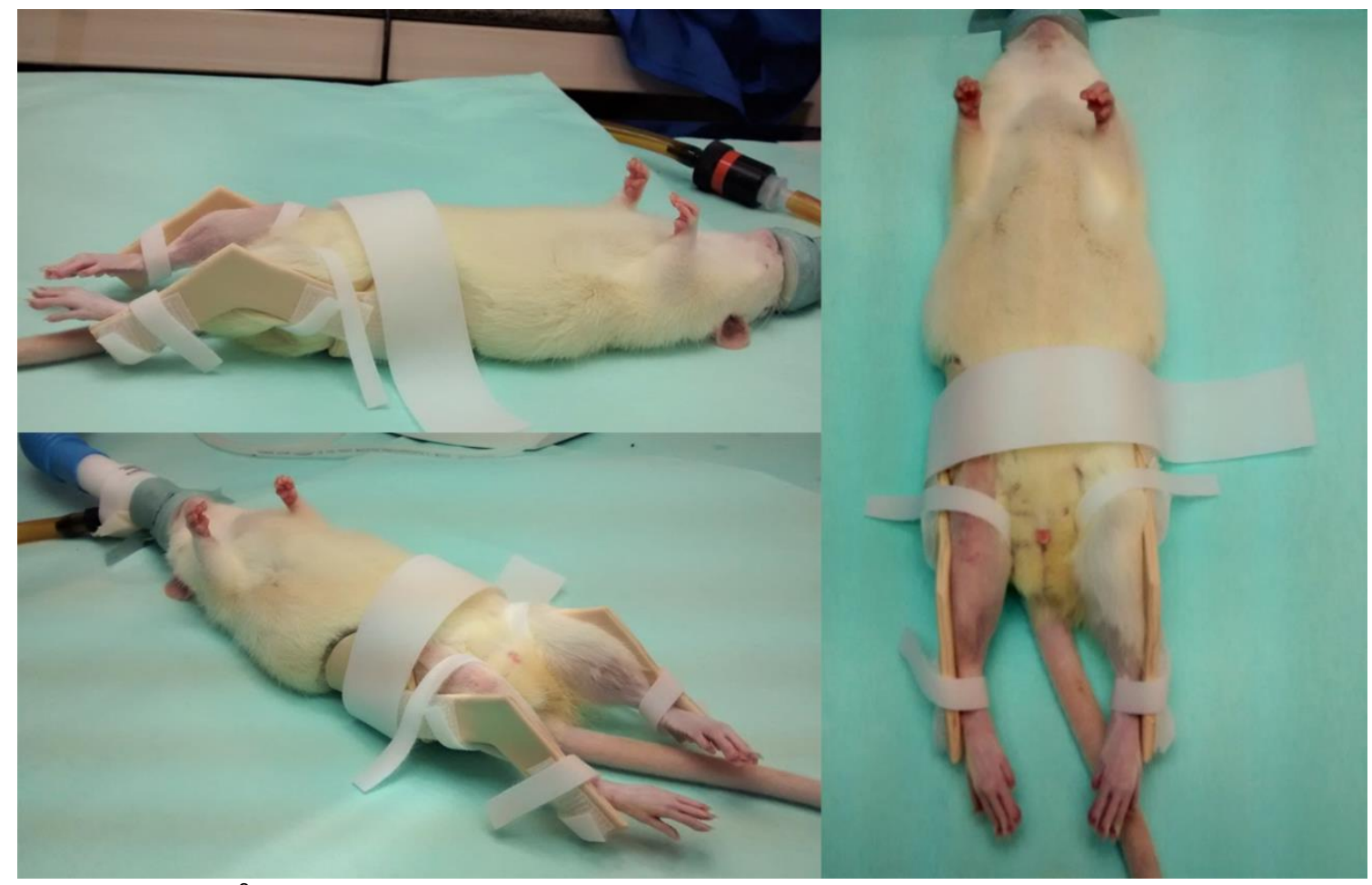

Flexão de $\approx 120^{\circ}$ do joelho para estabilizar o posicionamento do animal durante o Raio-X.

Figura 9. Órtese de termoplástico 


\subsubsection{Avaliação da descalcificação}

Para avaliar a eficácia do protocolo de descalcificação por EDTA 20\% (Item 2.11.1), algumas peças histológicas da articulação do joelho foram analisadas radiologicamente, com a finalidade de determinar o ponto final de desmineralização óssea (Figura 10). Para isso, fez-se a imagem dessas peças, após a fixação por paraformaldeído (PFA) 4\% e, mais uma vez por semana, aproximadamente a cada três trocas da solução de descalcificação. O ponto final do processo foi considerado o momento em que não era mais possível detectar sinais ósseos evidentes no interior da peça.

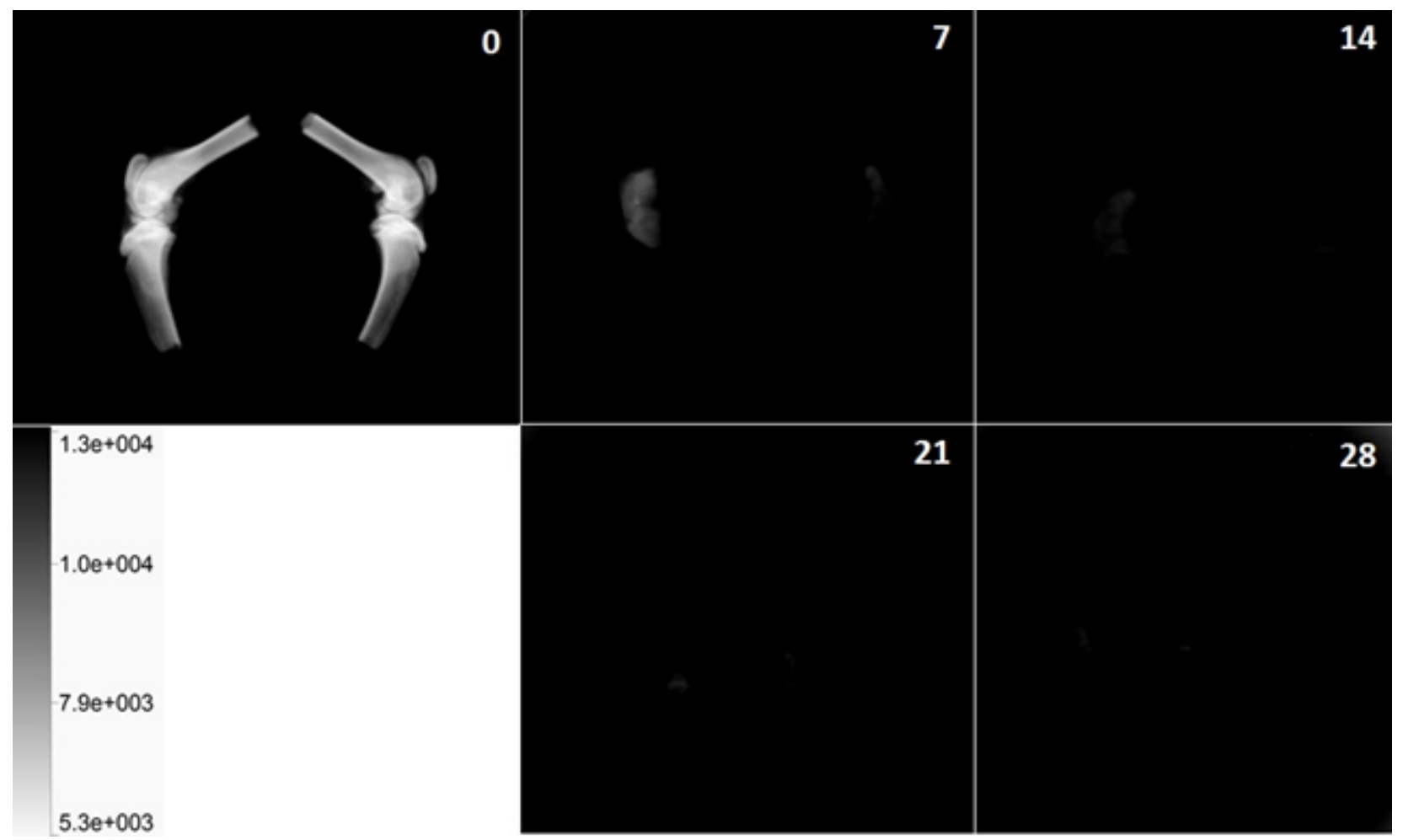

Articulação após fixação (0) e 7,14, 21 e 28 dias após processo de descalcificação. Escala numérica em fótons/segundos/milímetros quadrados (fótons $/ \mathrm{seg} / \mathrm{mm}^{2}$ ).

Figura 10. Avaliação de descalcificação por Raio-X

\subsection{Coleta de sangue/soro e lavado sinovial}

As amostras de soro e LS foram utilizadas para análise do perfil inflamatório (Item2.10). Os pontos de coleta estão descritos nas figuras 5 e 7. 


\subsubsection{Sangue/soro}

As coletas ocorreram sempre, entre 24 a 72 horas antes de cada intervenção experimental, com exceção das coletas de duas, quatro e 24 horas e uma semana, realizadas exatamente nos respetivos tempos. Para as coletas, os animais foram anestesiados com isoflurano $2-3 \%$ e submetidos à punção da veia gengival ${ }^{(100)}$ de até $500 \mu \mathrm{L} / \mathrm{mL}$ de sangue. Deixou-se o sangue em temperatura ambiente $\left(21^{\circ} \mathrm{C}\right)$, por 25 minutos para coagular. Em seguida, centrifugado à $10.000 \mathrm{~g}$, por cinco minutos, a fim de separar o soro. O soro coletado foi armazenado em outro tubo e colocado no gelo para transporte ao freezer $-80^{\circ} \mathrm{C}$.

\subsubsection{Lavado sinovial}

O procedimento de coleta de LS é o mesmo do procedimento cirúrgico de $\mathrm{DMM}($ Item2.2.1), até a etapa de incisão da pele. Com o membro semiflexionado e fixado sobre um tubo de $15 \mathrm{~mL}$, uma seringa de insulina de $1 \mathrm{~mL}$ (agulha de 27,5G) foi utilizada para injetar $50 \mu \mathrm{L}$ de soro fisiológico $(\mathrm{NaCl} 0.9 \%$ ), medialmente, ao tendão patelar. Do lado oposto, inseriu-se uma agulha de 24G, conectada a uma bomba peristáltica (Dose It - Integra Biosciences ${ }^{\circledR}$ ), com o intuito de sugar o conteúdo, com velocidade constante de $2 \mathrm{~mL} /$ minutos (Figura 11).

Pausadamente e de forma controlada, mais $250 \mu \mathrm{L}$ de soro foram injetados e sugados em volumes de $50 \mu \mathrm{L}$, sem ocasionar o rompimento da cápsula articular. Após a coleta inicial (Pré) de todo o LS, as agulhas foram retiradas para dar continuidade ao procedimento cirúrgico ou a eutanásia e necropsia (4S ou 12S). 


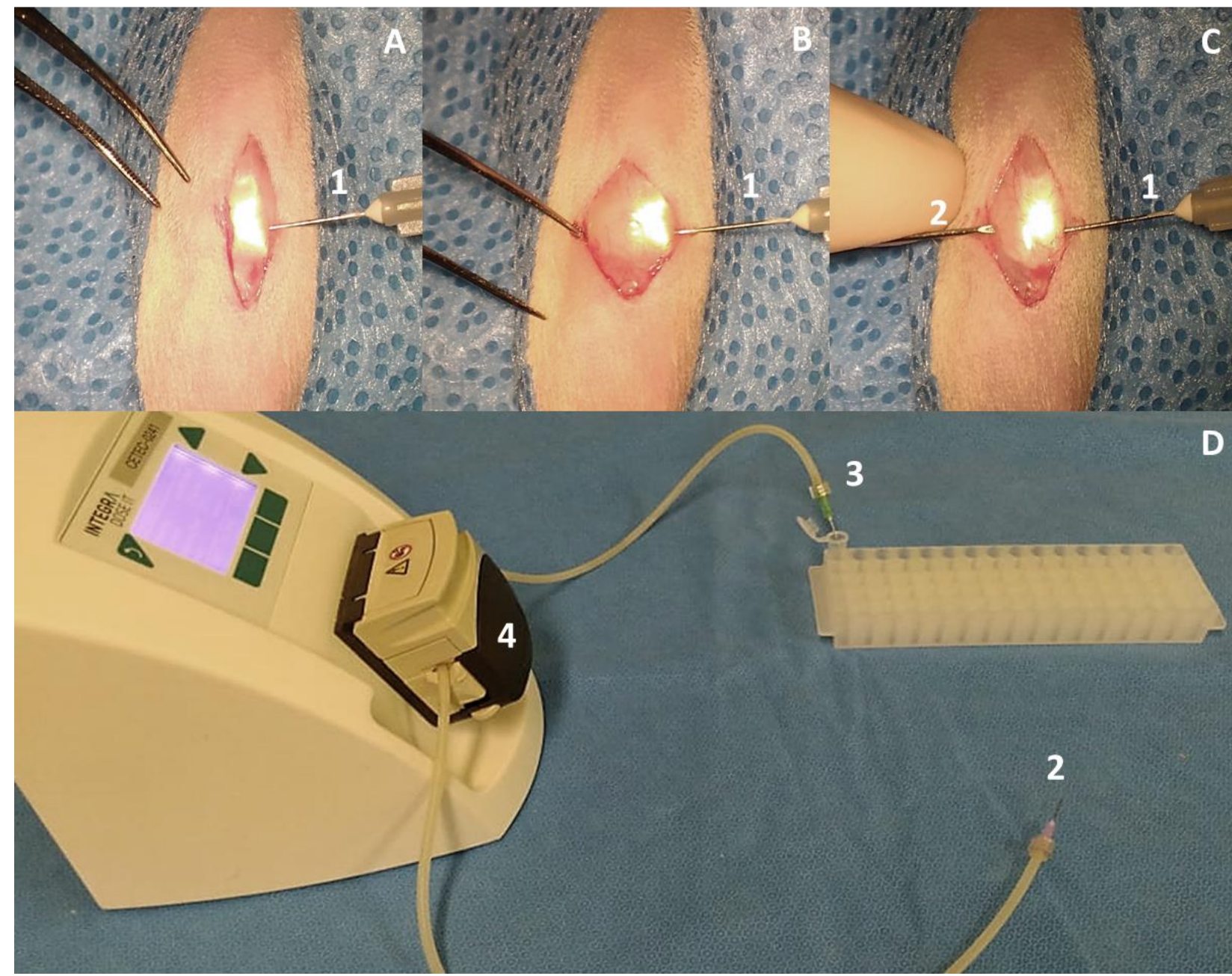

(A) Incisão na pele e inserção da agulha de 27,5G, medialmente ao ligamento patelar; (B) Injeção de $50 \mu \mathrm{L}$ de soro fisiológico 0,9\%; (C) Inserção da agulha de 24G para sucção do L. 1: Agulha 27,5G seringa de insulina (1mL); 2: Agulha de 24G, conectada a mangueira coletora; 3: Saída com agulha 21 ou $24 \mathrm{G}$ e tubo de coleta; 4: Bomba peristáltica.

Figura 11. Coleta do Lavado Sinovial

\subsection{Ensaio multiplex para determinar perfil inflamatório}

Analisou-se o perfil inflamatório pela quantificação de citocinas próinflamatórias e anti-inflamatórias, no plasma sanguíneo e no LS, utilizando-se um ensaio de painel magnético de beads (RECYTMAG-65K Millipore, MILLIPLEX MAP Rat Cytokine/Chemokine Magnetic Bead Panel - Immunology Multiplex) composto pelos seguintes analitos: IL-1 $\beta$, IL-6, IL-13, IL-10, TNFa, regulated on activation, normal $T$ cell expressed and secreted (RANTES), Macrophage Inflamatory Protein 1 alpha (MIP-1 $\alpha$ ), IL-4, IL-18 e Monocyte Chemoattractant Protein (MCP-1). A leitura desse painel magnético foi realizada no equipamento MAGPIX - xMAP technology, Luminex. Todos os procedimentos desse experimento se realizaram, segundo instruções do fabricante. 
Os dados foram analisados no software Analyst e consideradas válidas amostras com leitura de beads $\geq 30$, que apresentaram MFI (intensidade mediana fluorescente) acima do maior valor de MFI, detectado como nulo ou "Branco" na curva de concentração $(>0 \mathrm{pg} / \mathrm{mL}$ ). Foi aplicado o ajuste polinomial com cinco parâmetros à curva de concentração. Converteram-se em amostras de corridas diferentes (MFI para pg/mL), utilizando-se a mesma curva padrão. Amostras com MFI acima do Branco, porém abaixo do limiar delimitado pelo ajuste de cinco parâmetros tiveram os valores determinados, a partir de extrapolação polinomial $\left(R^{2}=1\right)$, entre os três últimos pontos da curva de concentração.

Para os dados de soro, com exceção do ponto de coleta anterior à cirurgia (Pré-cirurgia), realizou-se o delta, entre os valores dos pontos posteriores ao transplante $(2 \mathrm{H}, 24 \mathrm{H}, 1 \mathrm{~S}, 4 \mathrm{~S}$ e $12 \mathrm{~S})$, com o ponto anterior ao transplante (PósDMM/Pós-SHAM). Em casos onde o valor do Pós-DMM/Pós-SHAM não foi detectado pelo ensaio, o delta com os pontos posteriores ocorreu pela média de grupo para PósDMM/Pós-SHAM.

\subsubsection{Purificação das amostras}

Para possibilitar a leitura das amostras pelo equipamento Luminex, as amostras de soro e LS precisaram passar por uma etapa adicional, para eliminar possíveis resquícios de fibrina. As amostras foram descongeladas, em temperatura ambiente e aquecidas a $36^{\circ} \mathrm{C}$, por uma hora, bem como resfriadas novamente, a $4^{\circ} \mathrm{C}$ por mais uma hora. Tal procedimento permitiu a formação e aglutinação das redes de fibrina restantes. Então, essas foram centrifugadas à $1.000 \mathrm{~g} \mathrm{e} 4^{\circ} \mathrm{C}$, por cinco minutos. Com uma ponteira de $200 \mu \mathrm{L}$, o coágulo foi removido quando necessário, e o conteúdo limpo transferido para outro tubo. A etapa de centrifugação realizou-se, duas vezes para o soro e uma para o LS. Na sequência, as amostras se utilizaram para 0 experimento ou retornaram ao freezer $-80^{\circ} \mathrm{C}$. 


\subsubsection{Concentração proteica do lavado sinovial}

Para corrigir possíveis diferenças de diluição, devido ao tipo de coleta do LS, as amostras foram concentradas e equilibradas em $\mu \mathrm{g} / \mu \mathrm{L}$. Para isso, inicialmente quantificou-se a concentração de proteína de cada amostra, por meio do ensaio de BCA (bicinchoninic acid assay) (Pierce ${ }^{\mathrm{TM}}$ BCA Protein Assay Kit ThermoFisher $^{\circledR}$ ). Em seguida, determinou-se o volume de cada amostra, por uma pipeta de precisão. As amostras foram secas por evaporação, utilizando-se um SpeedVac Concentrator e ressuspensas em $\mathrm{NaCl} 0,9 \%$ no volume correto para ficarem com concentração de $6 \mu \mathrm{g} / \mu \mathrm{L}$.

\subsection{Processamento e avaliação do material histológico}

A ação das CTMs, nos componentes da articulação do joelho com $O A$, principalmente na $C A$ e na membrana sinovial, foram avaliadas por análises de coloração histológica e de imuno-histoquímica.

\subsubsection{Articulação do joelho}

Após a eutanásia, a articulação do joelho foi isolada para formar a peça histológica e fixada por $72 \mathrm{~h}$ em PFA $4 \%$. Passado o período de fixação, a peça foi enxaguada três vezes em água destilada, para remoção do excesso de PFA, e foi dado início ao processo de descalcificação. Esse processo durou 28 dias com as peças em solução de EDTA $20 \%$ (pH 7,4). O tempo necessário para descalcificação foi determinado, a partir das primeiras peças histológicas com acompanhamento radiográfico. A solução de EDTA foi trocada, duas a três vezes por semana. Ao final deste processo, a peça foi enxaguada cinco vezes e deixada em água destilada overnight. Uma nova etapa de $24 \mathrm{~h}$ de fixação por PFA $4 \%$ foi realizada, seguida de três enxagues em água destilada e transferência da peça para o álcool $50 \%$. Quando em álcool $50 \%$, o material descalcificado iniciou a bateria histológica, após duas horas ou foi armazenado a $4^{\circ} \mathrm{C}$, por até $72 \mathrm{~h}$. A bateria histológica foi composta por 11 soluções, nesta sequência: álcool 70\%; álcool 80\%; álcool 90\%; álcool 100\% - I; álcool 100\% - II; 
álcool 100\%+Xilol - I; álcool 100\%+Xilol - II; Xilol - I; Xilol - II; Parafina - I; Parafina - II. A peça histológica permaneceu 60 minutos em cada solução. Após a Parafina - II, a peça foi resfriada com o ângulo do joelho de $\approx 120^{\circ}$ e utilizado um transferidor geométrico como referência.

A articulação descalcificada e parafinada foi incluída, frontalmente, em um bloco de parafina. Realizaram-se cortes coronais, com cerca de 5-6um de espessura, no micrótomo Leica $425^{\circledR}$ (Figura 12).

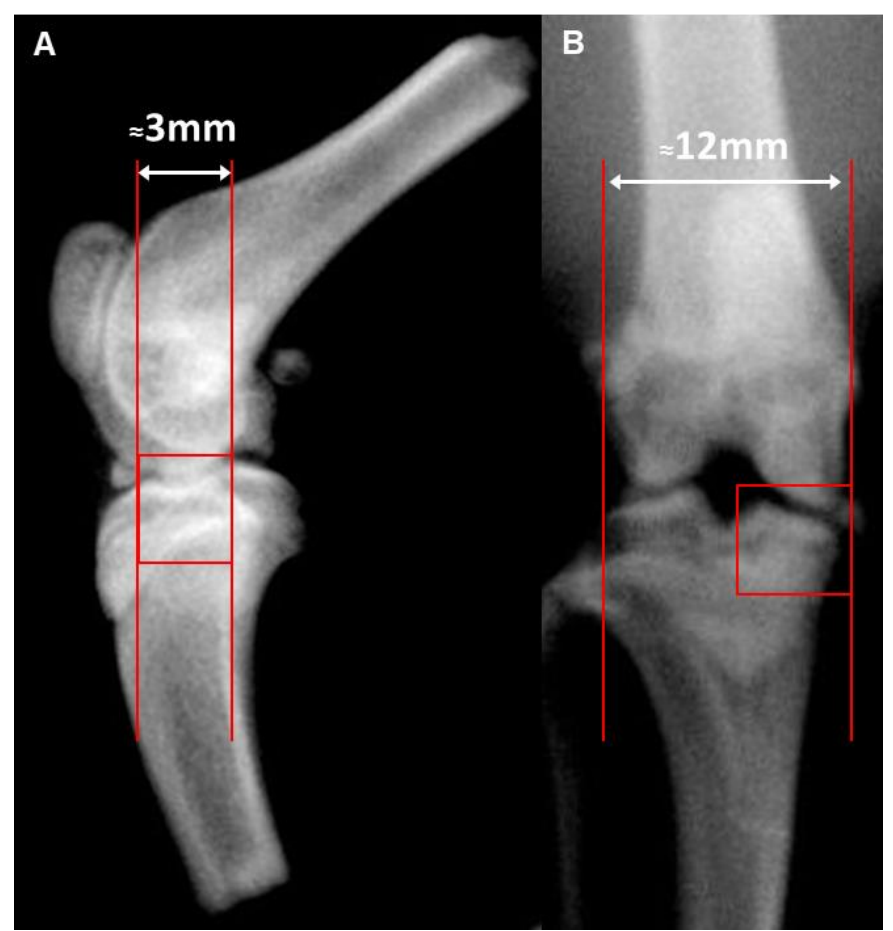

(A) Plano sagital medial; (B) Plano coronal frontal. Linha vermelha delimita área útil da peça. Quadrado vermelho delimita o platô tibial medial, utilizado para avaliação quantitativa da peça.

Figura 12. Radiografia da peça histológica da articulação do joelho

\subsubsection{Tecidos moles}

Além da articulação, também se isolaram dos animais do estudo agudo (Item 2.4), que receberam transplante intravenoso: pulmão, rim, fígado, baço, pâncreas e o quadríceps femoral. Esses tecidos foram fixados, por 24h, em PFA 4\% e, em seguida, desidratados por solução de sacarose a $15 \%$ e outra solução a $30 \%$, sempre a $4^{\circ} \mathrm{C}$. A troca de solução se deu, quando o tecido submergiu, indicando assim 
a eliminação de água (overnight ou 24 horas). Finalizado tal processo de desidratação, os materiais foram congelados em freezer $-80^{\circ} \mathrm{C}$.

O tecido preparado foi seccionado em criostato (LEICA), com

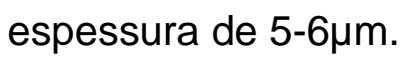

\subsubsection{Análise semiquantitativa da cartilagem e membrana sinovial}

Utilizou-se a coloração de Fast Green e Safranina-O, com a finalidade de avaliar o grau histológico de $O A$, seguindo as escalas semiquantitativas para lesão da cartilagem (0-6) e hiperplasia sinovial (0-3), propostas pela iniciativa histopatológica da "The OARSI histopathology iniciative". ${ }^{(101,102)}$ Também, seguindo as recomendações de tal iniciativa, mensurou-se o tamanho da superfície lesão, em micrômetros. Para isso, utilizaram-se 10 lâminas histológicas, com cortes coronais do joelho. Esses cortes foram obtidos, ao longo da área que compreende o início e o fim da região do PTM, não coberta pelo menisco medial. Se coletaram todos os cortes possíveis. Após divisão matemática, recuperamos 10 lâminas, igualmente distribuídas, ao longo da área coletada. As avaliações foram realizadas apenas no PTM, região na qual se encontra o foco da lesão da cartilagem, provocada pelo modelo DMM. O valor da lesão foi calculado, a partir da soma das três lâminas com maior quantificação, dentre as 10 selecionadas para análise.

Para a análise da hiperplasia sinovial, utilizou-se a imagem da membrana sinovial, oposta ao lado em que se deu a incisão cirúrgica do modelo animal de DMM.

O tamanho da superfície da lesão na cartilagem foi mensurado, valendo-se do software "Leica-LAS V4.8".

\subsubsection{Imuno-histoquímica - cartilagem}

Para melhor avaliar a degradação da cartilagem e evolução da $O A$, valeu-se da análise de imuno-histoquímica, para localização do colágeno tipo II e do colágeno tipo I. 
A análise da reação imuno-histoquímica se realizou com 0 kit Vectastain Universal - ABC kit (Vector Laboratories, Cat PK 6200), seguindo as instruções do fabricante. Os cortes foram submetidos a tratamento de recuperação antigênica, com tampão citrato (Vector Antigen Unmasking Solution, Citrate-based; H3300) em alta temperatura (banho-maria em micro-ondas) por 6 minutos; resfriados a temperatura ambiente, por 30 minutos. Após, bloqueio das peroxidases endógenas com solução de peróxido de hidrogênio (Bloxall ${ }^{\mathrm{TM}}$ Blocking Solution, SP-6000), por 10 minutos, seguido de bloqueio das interações inespecíficas com soro de cavalo (Blocking Serum; PK-6200), por 20 minutos. E, incubação por 1 hora, com o respectivo anticorpo primário: Anti-Colágeno I (ab 34710) e Anti-Colágeno II (ab 34712), ambos da Abcam. Inicialmente, testaram-se diferentes concentrações do anticorpo em 1:50, 1:100, 1:200. Após isso, os cortes foram incubados, por 30 minutos, com o anticorpo secundário universal do kit (Anti-Mouse lgG/Rabbit lgG). Em seguida, incubação, por 30 minutos, com solução avidina do kit (Avidin $\mathrm{DH})$ e revelação, com solução de peroxidase como substrato (Vector VIP SK-4600).

\subsubsection{Imuno-histoquímica - Luciferase}

Realizou-se um teste inicial, a fim de avaliar a eficiência do anticorpo (Anti-FireFly Luciferase Luciola cruciata ab 187340 - Abcam $^{\circledR}$ ) em células com expressão transgênica de Luciferase, por imunocitoquímica. A permeabilização das células foi realizada com solução de saponina $0,1 \%$, e o bloqueio com soro de cavalo (Blocking Serum; PK-6200), por 20 minutos. Testaram-se as diluições do anticorpo, em 1:100, 1:250 e 1:500. Para a realização da técnica, utilizou-se o kit Vectastain Universal - ABC kit (Vector Laboratories, Cat PK 6200), seguindo as instruções do fabricante. Para revelação, usou-se a peroxidase roxa como substrato (Vector VIP SK-4600). Optou-se em apresentar a imagem sem contra-coloração.

\subsection{Análise funcional da marcha}

Com intuito de avaliar alterações motoras, provenientes do modelo animal de OA por cirurgia de DMM, desenvolveu-se um sistema de filmagem e análise cinemática 2D de marcha. 
Outros testes, como Rotarod ${ }^{\circledR}$ (Ugo Basile), Catwalk ${ }^{\circledR}$ (Noldus) e Teste de Escalada foram aplicados, com o intuito de auxiliar a compreensão dos dados de marcha $2 \mathrm{D}$.

\subsubsection{Marcha 2D}

Os animais foram familiarizados com a esteira ergométrica (AVS Projetos $^{\circledR}$ ), na qual realizaram os testes. Após a familiarização, determinou-se a velocidade $(\mathrm{m} / \mathrm{min})$ limite de marcha (VM), ou seja, a velocidade imediatamente anterior a de transição marcha/corrida (VT). O teste se realizou com VM=18m/min, em $0 \%$ de inclinação e consistiu em tentativas de 60 segundos, seguidas por 60 segundos de intervalo. Foram gravadas em vídeo, ao menos 10 passadas até que se completasse grande deslocamento anteroposterior do animal na esteira, em relação ao ponto central da câmera. Filmou-se 0 teste, utilizando-se uma GoPro Hero $4^{\circledR}$ a 240 quadros/segundo.

Primeiramente, o animal foi anestesiado para coleta de sangue (Item 2.9). Em seguida, ainda anestesiado e após tricotomia do MI direito, foi posicionado em decúbito ventral, com os membros alinhados à mesa (Figura 13).

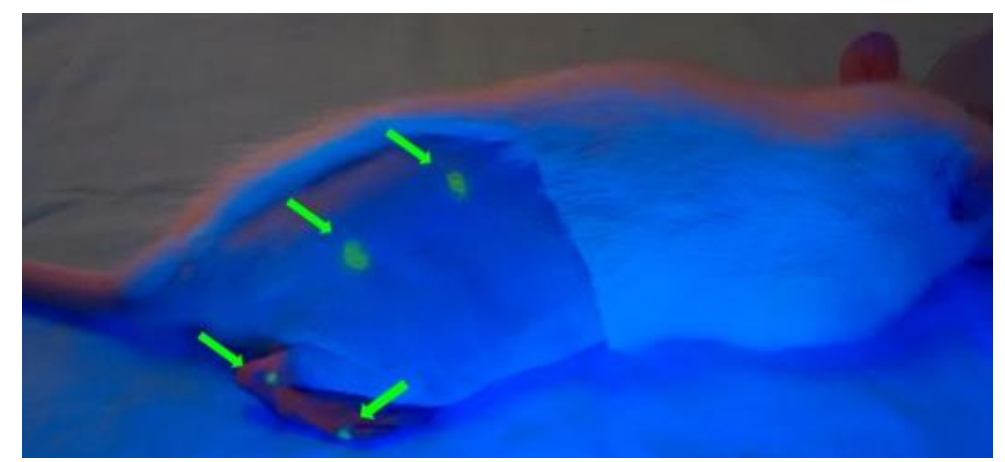

Posicionamento do animal para marcação das articulações.

Setas verdes: marcações nos pontos articulares.

Figura 13. Marcação articular para marcha 2D

Então, após a palpação, identificaram-se as regiões da crista ilíaca $(\mathrm{Cl})$, trocânter maior do fêmur (TM), maléolo lateral da tíbia (ML) e segundo metatarso (2MT). Esses pontos articulares foram pintados, com tinta fluorescente não tóxica, a fim de serem evidenciados, com auxílio de luz negra (20 W, 127 V). Com o membro em $90^{\circ}$ de flexão, a distância do platô tibial lateral (PTL) até o do ML, mensurou-se por 
paquímetro. O PTM e ML são de fácil apalpação, no que se refere a tal medida, e reproduzem o tamanho real da tíbia, quando avaliada ex vivo, após necropsia. Porém, o mesmo não ocorre com o fêmur, por não ser possível acessar o trocânter maior para mensuração. Então, a fim de determinar o tamanho correto do fêmur, o valor da tíbia foi acrescido de 0,4mm (ex.: Tíbia = 3,2 cm; Fêmur $=3,6 \mathrm{~cm}$ ), uma vez que, quando mensurados em necropsia, essa diferença se reproduz em quase todos os casos.

Após uma hora, os animais foram avaliados. Os dados, exportados da câmera e analisados no software gratuito Kinovia ${ }^{\circledR} 8.2$.

Neste software, os pontos articulares foram rastreados, durante a passada, gerando coordenadas $\mathrm{X}$ e $\mathrm{Y}$. Calibrou-se e converteu-se, de pixel para centímetro, os pontos articulares rastreados. Isso se deu, por meio de um calibrador de um $1 \mathrm{~cm}^{2}$, fixado na esteira, a $40 \mathrm{~cm}$ de distância da câmera (Figura 14).

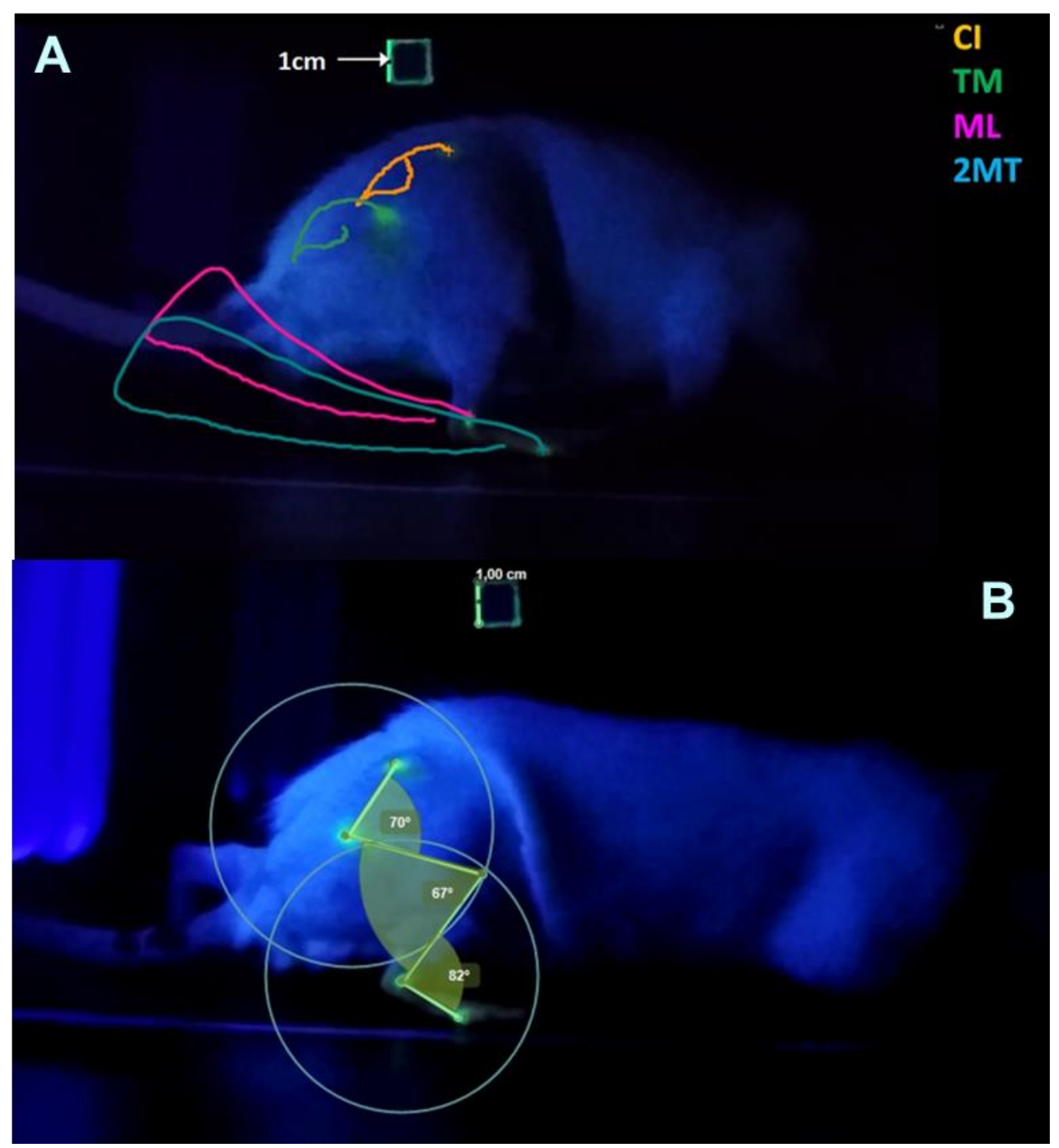

(A) Cl: Rastreamento quadro a quadro dos pontos crista ilíaca; TM: trocânter maior; ML: maléolo lateral; 2MT: segundo metatarso. Seta branca indica o calibrador de $1 \mathrm{~cm}^{2}$ da imagem. (B) Método de triangulação do ponto do joelho para cálculo angular.

Figura 14. Análise da marcha pelo software Kinovia $^{\circledR} 8.2$ 
Os dados de coordenadas $X$ e $Y$ de cada marcador foram exportados e analisados no software MatLab ${ }^{\circledR}$, utilizando-se uma rotina de programação, desenvolvida, especificamente, para essas análises. A rotina elaborada encontra-se no Anexo 2.

O ponto articular do joelho é encontrado por método de triangulação, utilizando-se os pontos articulares TM e ML como referência, e o comprimento do fêmur e da tíbia como raios da circunferência. ${ }^{(103)}$

Os valores de ângulo, para cada articulação, determinam-se pela média das 10 passadas capturadas na filmagem. Também, frequência (passadas/min) e amplitude de passada (cm) foram mensuradas.

\subsubsection{Catwalk ${ }^{\circledR}$}

Utilizou-se tal teste, com a finalidade de evidenciar possíveis diferenças na descarga de peso entre membros, por meio de detecção de intensidade luminosa do contato da pata, ao atravessar uma passarela de vidro (Figura 15).

Antes de cada coleta, os animais realizaram ao menos três tentativas para familiarização com o teste. Em seguida, foram realizadas outras três tentativas, com o máximo permitido de $60 \%$ de oscilação de velocidade entre passadas. O limiar de detecção de intensidade de luz verde foi de 0.1 , ajustado no software CatWalk ${ }^{\circledR} \mathrm{XT}$.

Aplicou-se tal teste, antes e nove semanas após a cirurgia DMM, em animais aleatoriamente selecionados $(\mathrm{N}=24)$, independentemente de grupo.

Coletaram-se as variáveis: área média da pegada $\left(\mathrm{cm}^{2}\right)(\mathrm{AMP})$, intensidade máxima da pegada (pixel) (IMaxP) e intensidade média da pegada (pixel) $(\mathrm{IMdP})$.

Os dados foram normalizados, inicialmente, pelo peso corporal e, em seguida, pela AMP, a fim de diminuir a influência de oscilações no tamanho do animal. 


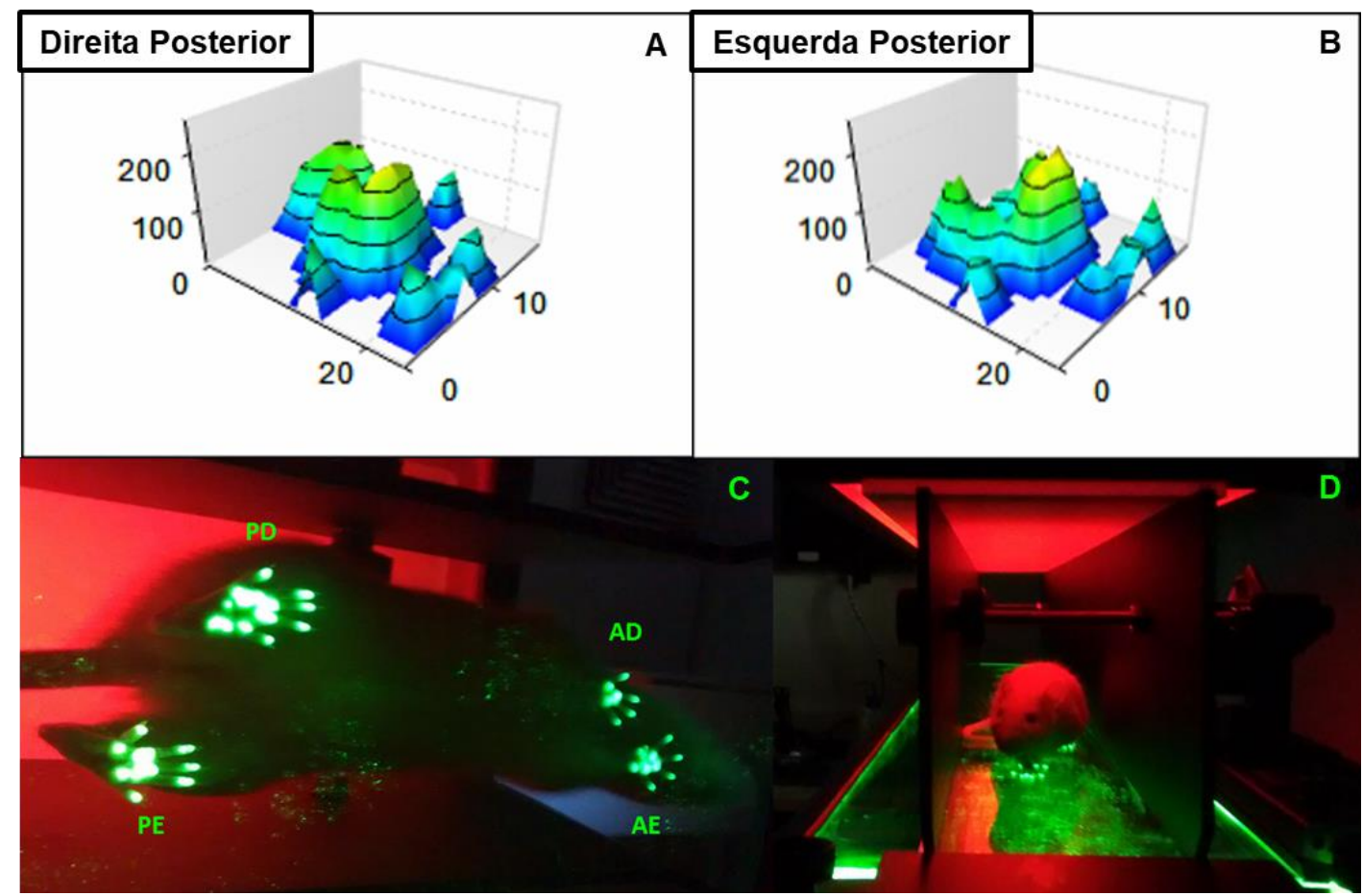

(A, B) llustração gráfica da detecção da intensidade de luz verde na área da pisada. (D) Visão inferior do animal na plataforma de caminhada. (C) Visão frontal do animal na plataforma de caminhada. PD: Posterior direita; PE: Posterior esquerda; AD: Anterior direita; AE: Anterior esquerda.

Figura 15. Sistema CatWalk ${ }^{\circledR}$

\subsubsection{Rotarod ${ }^{\circledR}$}

Também, para avaliar a função motora dos animais realizou-se o teste no aparelho $\operatorname{Rotarod}^{\circledR}$ (Figura 16). Consiste em um rotor cilíndrico, no qual o animal deve permanecer sobre, durante variações de velocidade de rotação. $O$ teste utilizado foi um de incremento constante de velocidade. Iniciou-se, com 5 minutos de permanência sobre o rotor e velocidade constante de 4rpm, para adaptação do animal ao teste. Após 30 minutos de intervalo, aplicou-se o teste incremental de 4 a $40 \mathrm{rpm}$ (incrementos de 4rpm a cada 30 segundos), com duração máxima de 300 segundos. Três tentativas por dia, com intervalo de 30 minutos, foram realizadas por três dias consecutivos. ${ }^{(104)}$ A adaptação ocorreu, apenas uma vez ao início de cada dia.

Contabilizou-se o tempo (segundos) de permanência no rotor, bem como o maior valor obtido em cada dia, considerado para comparações. 


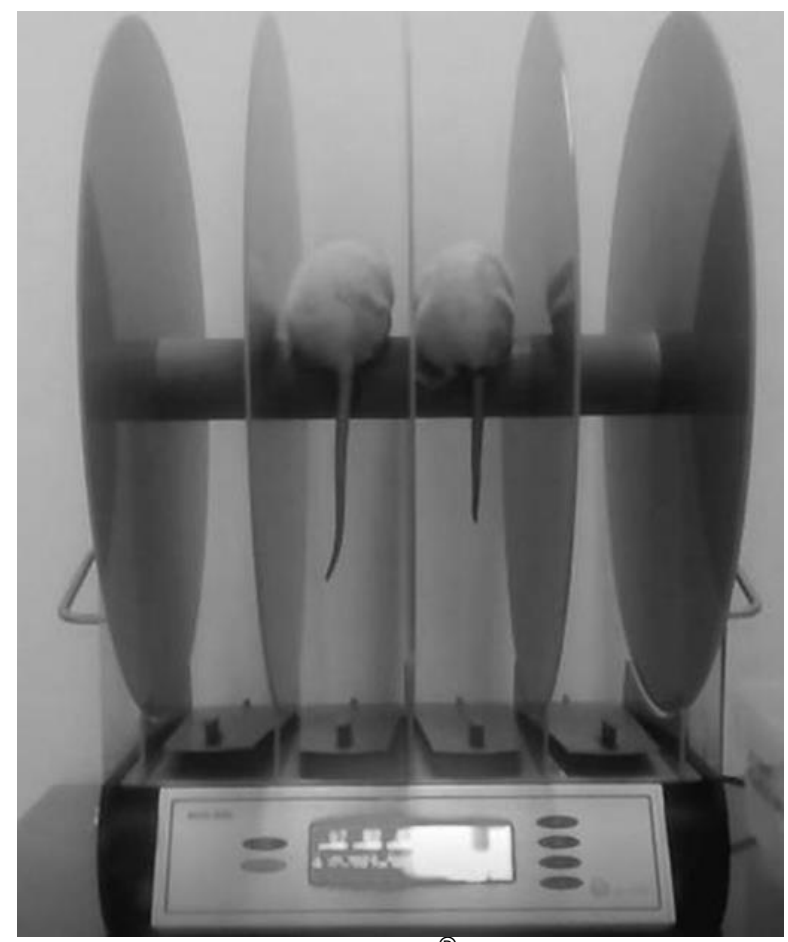

Figura 16. Sistema Rotarod ${ }^{\circledR}$

\subsubsection{Escalada}

Como teste funcional, realizou-se o de escalada (Figura 17). Consiste na mensuração do tempo que o animal demora para escalar uma escada vertical de $100 \mathrm{~cm}$, até uma caixa escura de fuga. Inicialmente, o animal foi adaptado à escada, a partir do seu posicionamento em relação a caixa de fuga, fim (topo), meio e início (próximo ao chão). Após 30 minutos, três tentativas se realizaram, com intervalo de 30 minutos entre elas. Realizou-se o teste, por três dias consecutivos, e a adaptação, uma vez ao início de cada dia.

Uma tentativa é considerada válida, quando o animal não fica mais do que 5 segundos parado, explorando o ambiente durante o percurso. $O$ tempo (segundos) de escalada foi contabilizado e o menor valor obtido, em cada dia, considerado a comparações. Normalizaram-se os dados, pela massa corporal do animal, no dia do teste. 


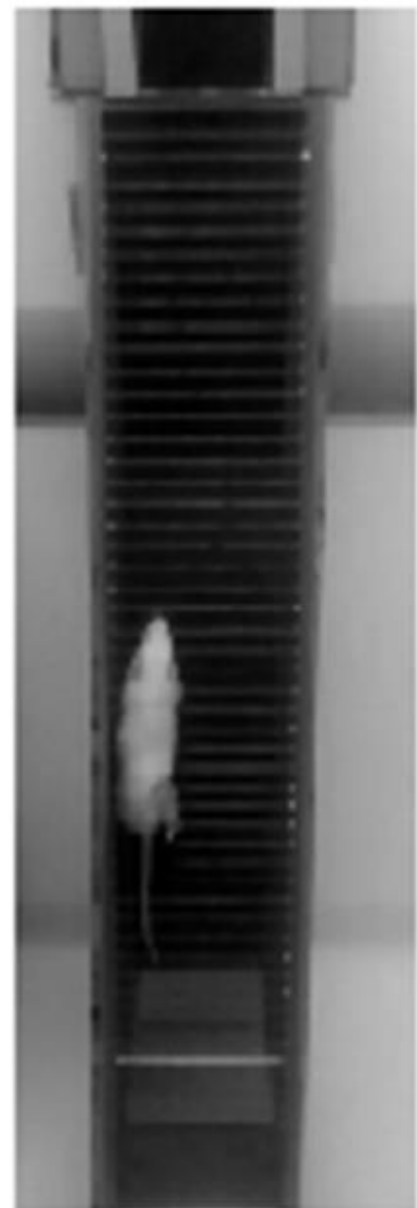

Figura 17. Escada do teste de escalada

\subsection{Dissecação e pesagem muscular}

Utilizou-se a análise do peso muscular, como uma forma indireta de avaliar possíveis alterações funcionais. Para tanto, a necropsia do animal ocorreu, após a eutanásia, e os músculos dos membros inferiores foram dissecados. A figura 18 ilustra a metodologia para dissecação dos músculos do quadríceps, gastrocnêmio/sóleo e tibial anterior. Após a coleta dos músculos (Figura 19), esses foram colocados em placas de petri, sobre gelo, até o momento da pesagem em balança de precisão (AUX 220 - SHIMADZU ${ }^{\circledR}$ ). O valor de peso muscular (gramas) normalizou-se pela massa corporal do animal (gramas). O equilíbrio muscular foi obtido pela razão, entre o peso muscular do membro inferior, operado (MIOA) pelo respectivo músculo do - membro inferior contralateral não operado (MICL). 


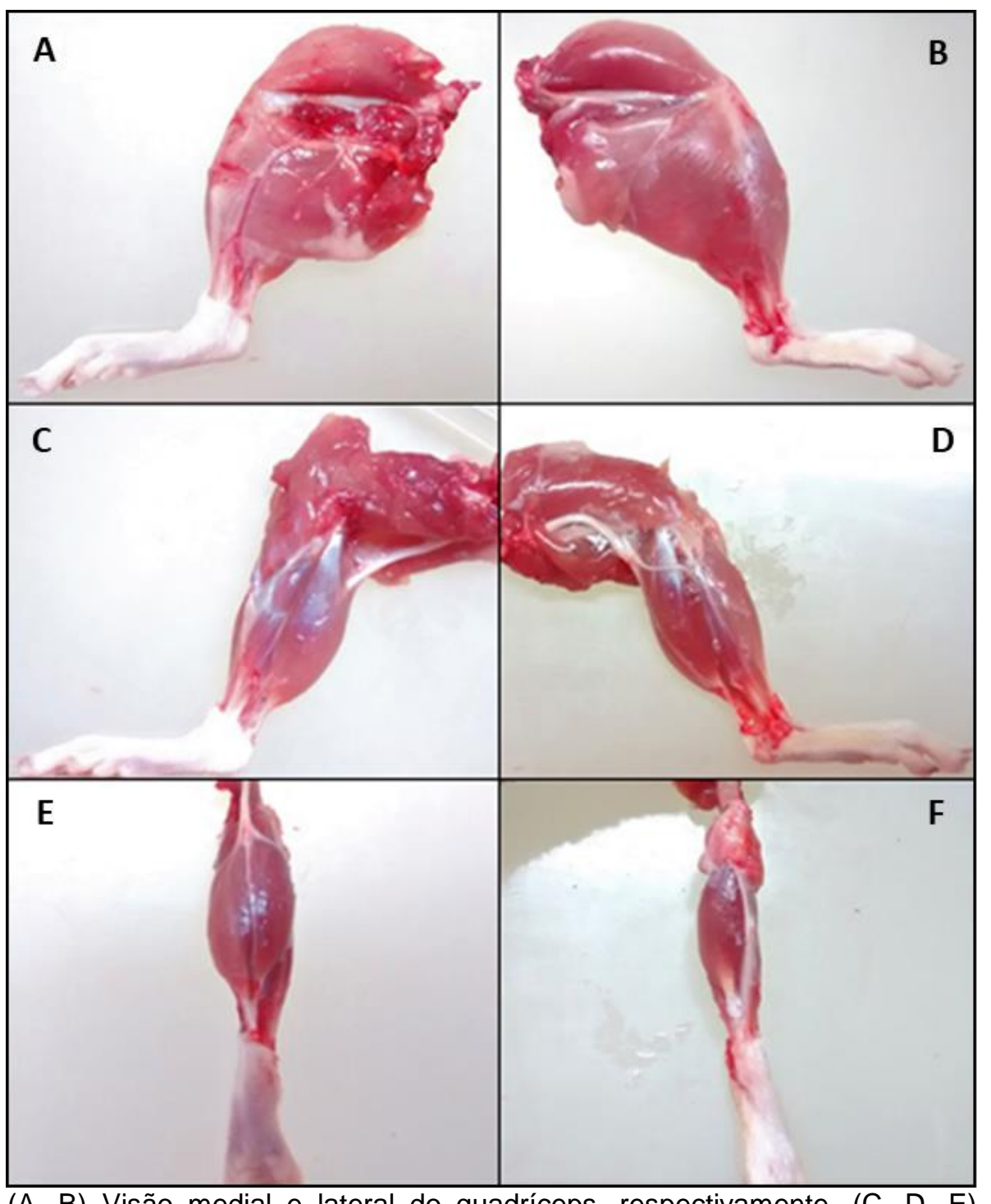

(A, B) Visão medial e lateral do quadríceps, respectivamente. (C, D, E) Visão lateral, medial e posterior do gastrocnêmio/sóleo, respectivamente. (F) Visão frontal do tibial anterior.

Figura 18. Imagem ilustrativa da dissecação muscular do membro inferior 


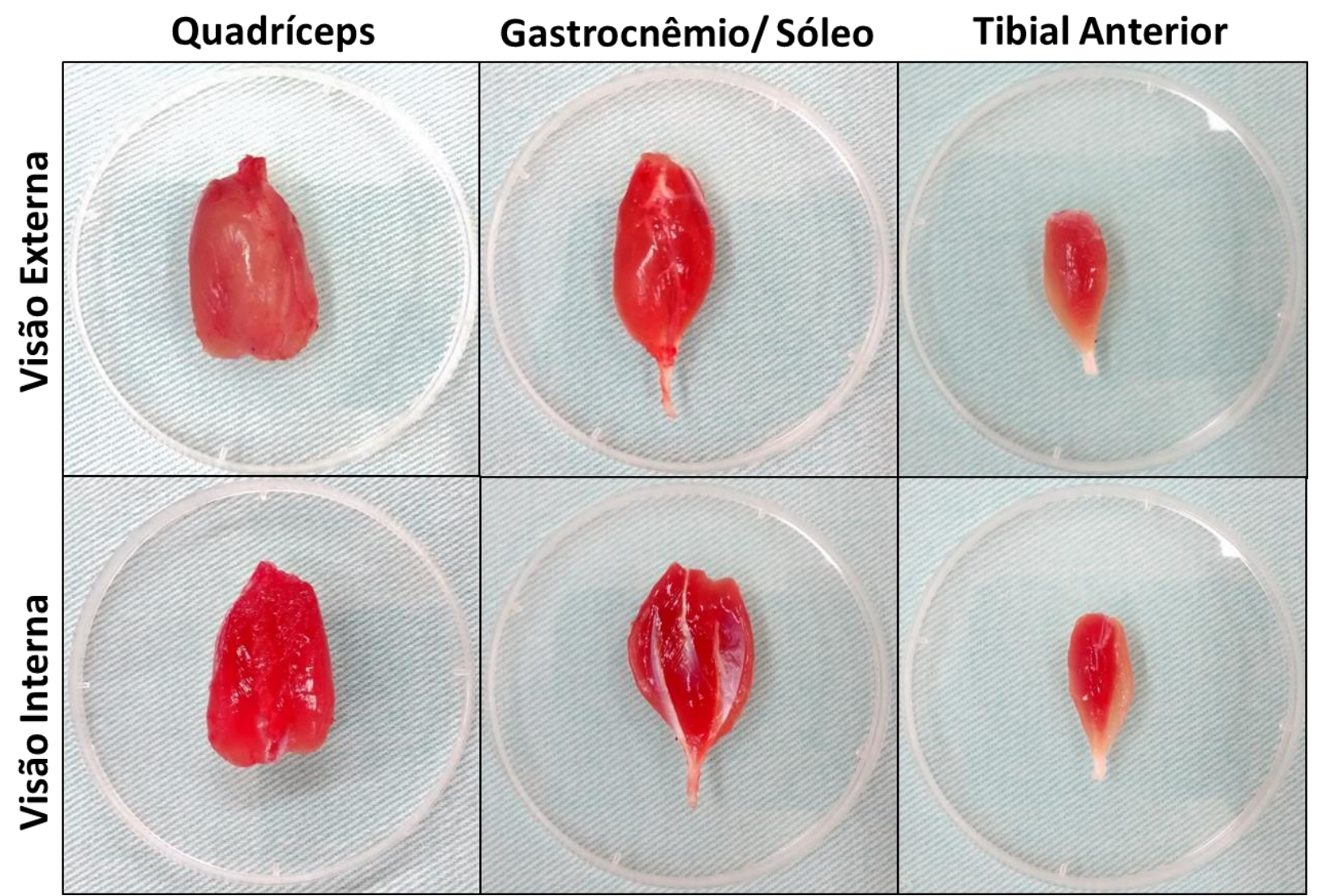

Figura 19. Visão interna e externa do quadríceps, gastrocnemio/sóleo e tibial anterior, dissecados para pesagem

\subsection{Análise estatística}

Avaliaram-se os dados, quanto a normalidade, pelo teste Kolmogorov-Smirnov todas as análises realizadas a variáveis paramétricas. Todos os gráficos encontram-se representados pela média \pm desvio padrão. Para todas as comparações, de até três médias, utilizou-se, como post hoc, o teste de Fisher's LSD e, para comparações, com mais de três médias, o de Sidak. Considerou-se significante $\alpha \leq 0,05$. Análises foram realizadas apenas para grupos com $N \geq 3$.

Removeram-se Outliers, valendo-se do método de intervalos interquartis (IIQ). O IIQ determinou-se pelo delta, entre o primeiro quartil (Q1) e terceiro quartil (Q3) (Q3 - Q1). Não se consideraram para análise dados com valores menores do que "Q1 - (1,5 x IIQ)" e maiores do que "Q3 + (1,5 x IIQ)".

As análises estatísticas, gráficos e o IIQ geraram-se pelo software GraphPad Prism 8 (GraphPad Software). 


\subsubsection{Luminescência}

Realizou-se a análise da intensidade do sinal de luminescência por Anova One Way, para diferenças entre coletas $(2 \mathrm{H} \times 24 \mathrm{H} \times 1 \mathrm{~S})$. Fez-se uso do delta entre os pontos de coleta, a fim de determinar a variação do sinal de luminescência em cada período. $O$ valor do delta também se normalizou, pelo número de horas decorridas em cada período, com o intuito de determinar a variação do sinal, em função do tempo. As análises dos deltas também se deram, utilizando-se Anova One Way para diferenças entre períodos $(2 \mathrm{H}-1 \mathrm{~S} \times 2 \mathrm{H}-24 \mathrm{H} \times 24 \mathrm{H}-1 \mathrm{~S})$.

\subsubsection{Análise muscular}

As análises comparativas, em relação aos membros inferiores (MIOA $x$ MICL) do grupo controle (CON-13S ou CON-21S), ocorreram por Teste $t$ pareado. A comparação da diferença percentual MIOA $x$ MICL, entre os três músculos, se realizou por Anova One Way, para valores correspondentes.

As comparações, entre vias de transplante (IAt $x \mathrm{IVt}$ ) aos grupos DMM+CTM (4S ou 12S), ocorreram por Teste t não pareado. Para comparações entre intervenções (DMM+PLACEBO $x$ SHAM+CTM $x$ DMM+CTM) de grupos, com a mesma via de transplante (IAt ou IVt) e tempo de coleta (4S ou 12S), fez-se uso do teste ANOVA One Way.

\subsubsection{Frequência, amplitude passada, Catwak $^{\circledR}$, $\operatorname{Rotarod}^{\circledR}$ e Escalada}

Fez-se uso de ANOVA One Way (Pré $x$ DMM $x$ SHAM) aos dados de frequência e amplitude de passada. Os dados de CatWalk foram analisados com Anova Two Way e medidas repetidas para MI (Operado xContralateral), assim como tempo de coleta (Pré-DMM $x$ Pós-DMM). Visando à análise dos testes de Escalada e Rotarod $^{\circledR}$, as coletas referentes aos momentos Pré $(C 1)$ e Pós (C4), não foram consideradas, com o intuito de reduzir o efeito de familiarização e aprendizagem dos testes. A fim de reduzir a variabilidade, na comparação entre grupos de animais, a média entre as coletas Pré (C2 e C3) do mesmo grupo, fez-se uso, para realizar o delta 
de performance intragrupo, (e.g.: $\mathrm{C} 4-(\mathrm{C} 2+\mathrm{C} 3) / 2)$ com todos os animais e tempos de coleta (C2, C3, C4 e C5). Com a finalidade de análise do delta, utilizou-se o teste Anova One Two Way, com medidas repetidas, com o intuito de comparação entre tipos de cirurgia (DMM $x$ SHAM) e tempo de coleta (C2 $\times$ C3 $\times$ C4 $\times$ C5).

\subsubsection{Histologia}

As análises comparativas entre intervenções (DMM+PLACEBO $x$ SHAM+CTM $x$ DMM+CTM) de grupos, com a mesma via de transplante e tempo de coleta foram realizadas, utilizando-se ANOVA One Way. Visando à comparação entre vias de transplante (IAt $x \mathrm{Vt}$ ) de grupos, com a mesma intervenção e tempo de coleta, usou-se o Teste t.

\subsubsection{Soro/sangue e lavado sinovial}

As amostras apresentaram distribuição não normal, devido a variabilidade do valor absoluto de concentração de citocinas. Por esse motivo, os valores de soro e lavado sinovial foram transformados, por raiz quadrada de dois. Assim, fez-se possível trazer as amostras para curva de normalidade e realizar análises paramétricas.

A análise das citocinas, antes e após cirurgia DMM, ocorreu por Teste t (Pré-DMM $x$ Pós-DMM) pareado.

As amostras referentes ao estudo agudo se analisaram, utilizando ANOVA Two Way, com medidas repetidas à comparação entre grupos (G-IAt $x$ G-IVt) e tempo de coleta (Pós-DMM $\times 2 \mathrm{H} \times 24 \mathrm{H} \times 1 \mathrm{~S}$ ). Nos casos em que o $\mathrm{N}$ amostral não se mostrou igual, em todos os tempos e grupos, fez-se uso da ANOVA Mixed-effects model.

Para o estudo longitudinal, as comparações entre intervenções (DMM+PLACEBO $x$ SHAM+CTM $x$ DMM+CTM) de grupos, com a mesma via de transplante e tempo de coleta, realizou-se por ANOVA One Way. A comparação entre vias de transplante (IAt $x \mid \mathrm{Vt}$ ) para grupos, com a mesma intervenção e tempo de coleta ocorreu por Teste t. 
3 RESULTADOS

\subsection{Obtenção de células-tronco mesenquimais de rato}

Obtivemos sucesso no isolamento, diferenciação e caracterização das células-tronco/estromais mesenquimais, extraídas da medula óssea do fêmur e tíbia de ratos Wistar Kyoto fêmeas.

\subsubsection{Isolamento celular}

Pode-se observar, na figura 20, o processo de formação de colônias, aderidas à superfície plástica da garrafa de cultura, e as células com fenótipo fibroblástico, característico de CTMs, após $72 \mathrm{~h}$ em cultura.

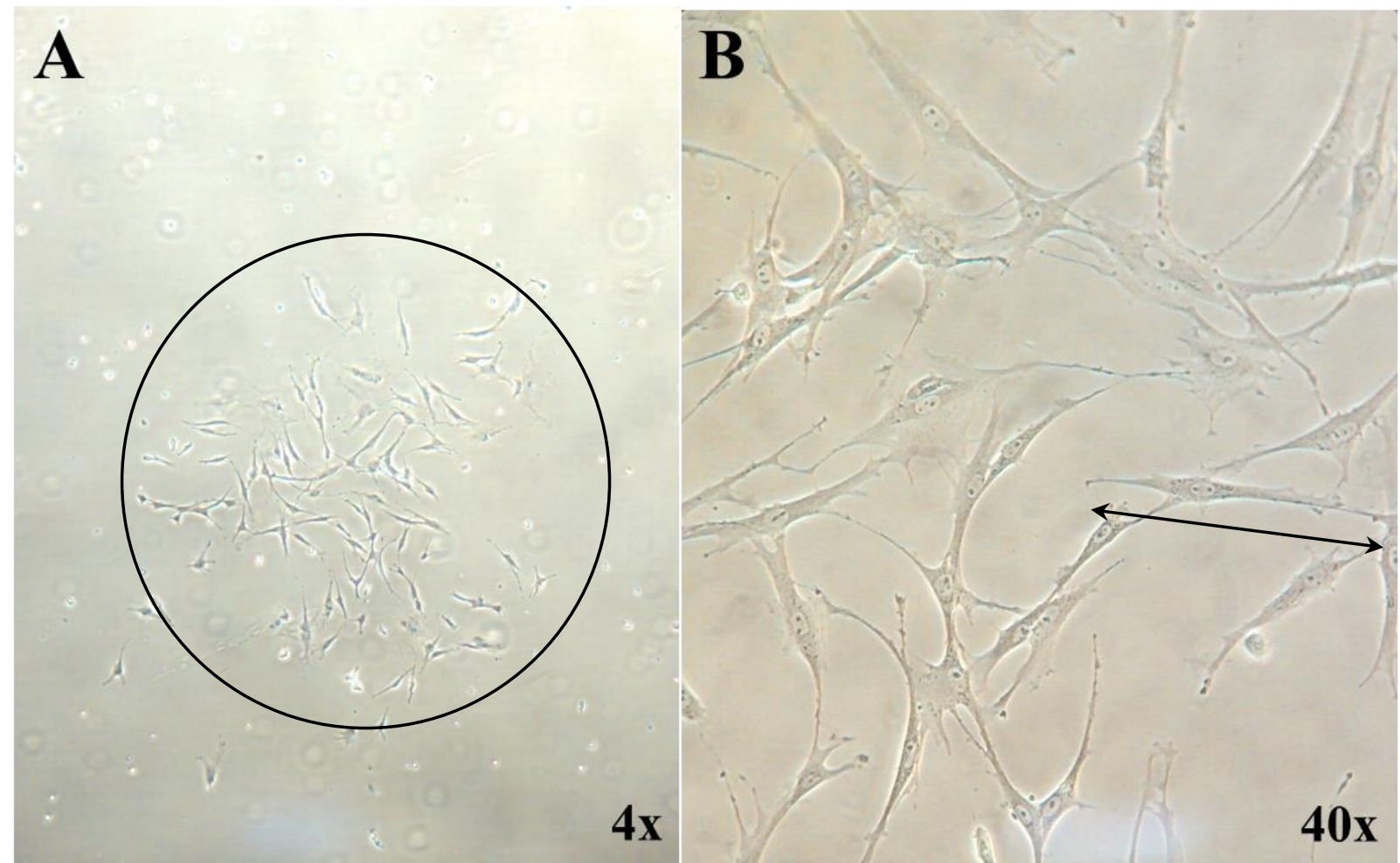

(A) Círculo indica formação de colônias de células aderidas, após processamento da medula óssea do rato. (B) Seta indica o fenótipo alongado fribroblástico das células, presentes nas colônias aderidas. Imagens adquiridas em culturas com 72 horas.

Figura 20. Colônias de células tronco mesenquimais, após isolamento 


\subsubsection{Diferenciação em linhagens mesenquimais}

Como se faz possível observar, na figura 21 , as células foram capazes de apresentar características adipogênica, osteogênica e condrogênica, após o período de cultivo em monocamada.

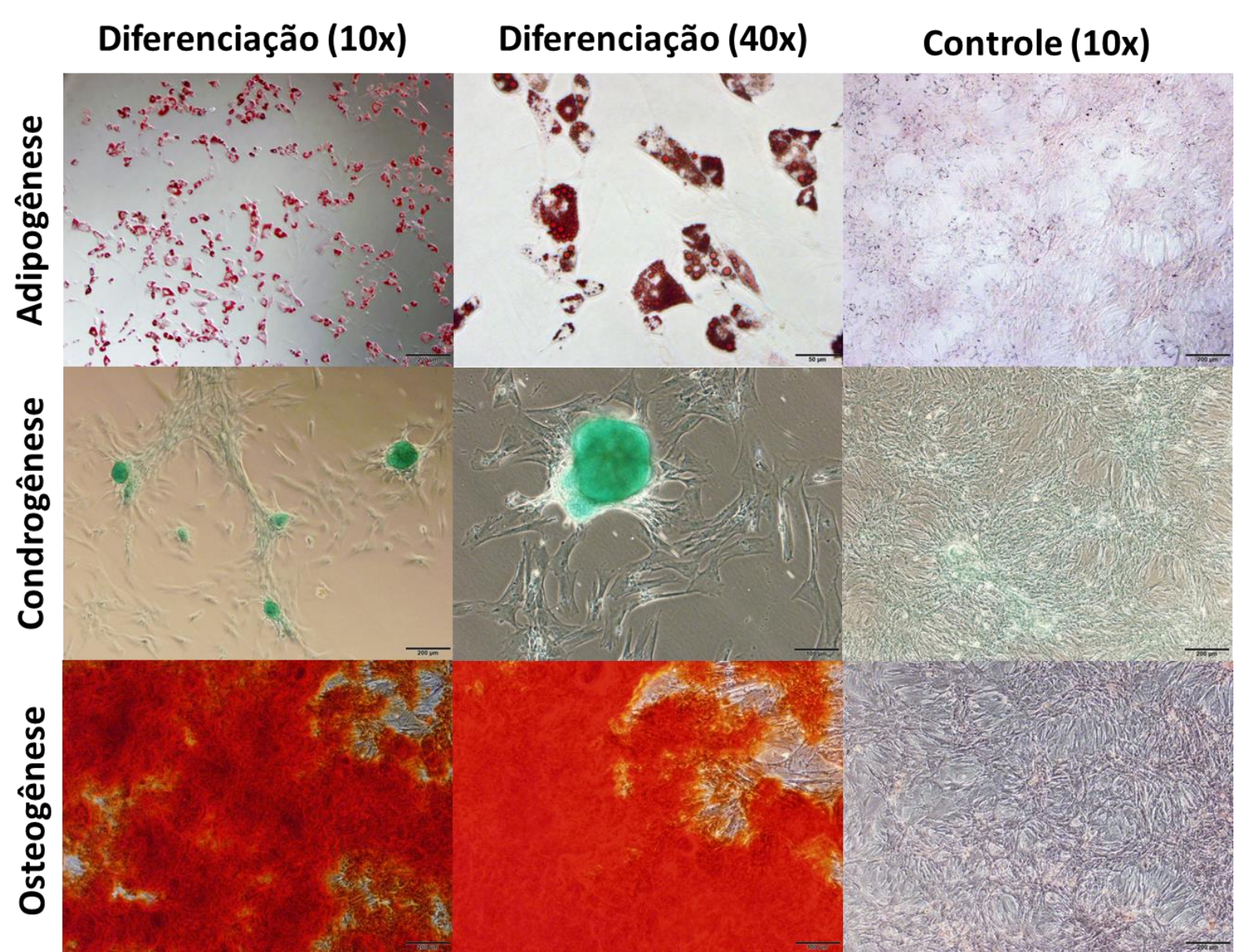

Imagem das células, após o cultivo com meio indutor de diferenciação e células, cultivadas em meio controle.

Figura 21. Diferenciação celular em linhagens mesenquimais

Também, as células quando cultivadas em micromassa, apresentaram coloração positiva para Alcian Blue e Safranina-O. 


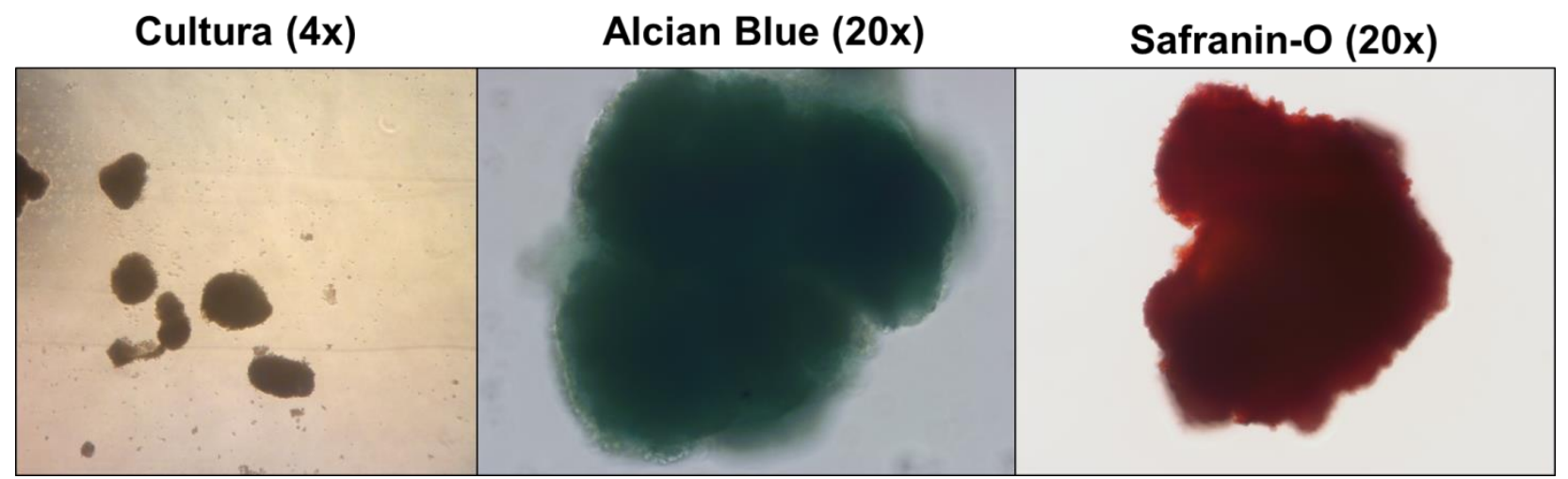

Figura 22. Diferenciação condrogênica em micromassa

\subsubsection{Caracterização por marcadores de superfície}

A tabela 2 resume a análise dos marcadores de superfície, utilizados na caracterização das CTMs. A caracterização pelo imunofenótipo constitui um dos critérios propostos pela InternationalSociety for CellularTherapy (ISCT). Os resultados demonstram que as células isoladas apresentaram um imunofenótipo, correspondente ao proposto pela ISCT. A figura 23 ilustra o perfil dos histogramas, obtidos durante a análise de cada marcador.

Tabela 2.Representação percentual positiva dos marcadores de superfície

\begin{tabular}{lcccccc}
\hline \multicolumn{7}{c}{ Marcadores de superfície } \\
\hline CD29 & CD90 & CD44 & CD105 & CD45 & CD34 & CD11b/c \\
$(\%)$ & $(\%)$ & $(\%)$ & $(\%)$ & $(\%)$ & $(\%)$ & $(\%)$ \\
\hline 100 & 99,8 & 100 & 97,7 & 1,6 & 2,78 & 1,41 \\
\hline
\end{tabular}

Célula-tronco mesenquimal de rato na sétima passagem do cultivo celular. 

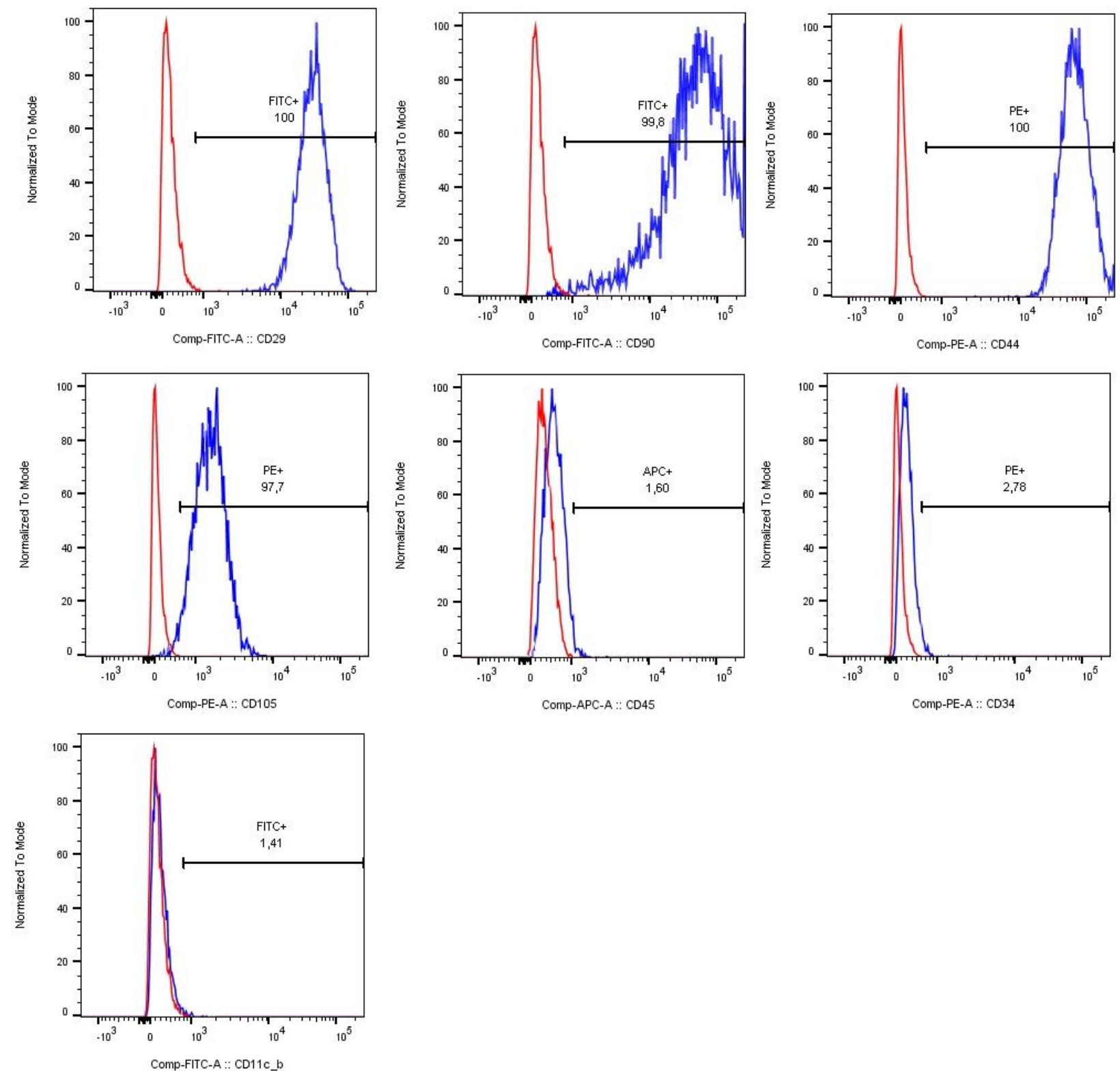

As células foram expandidas, até a sétima passagem, e analisadas por citometria de fluxo (10.000 células foram analisadas). $O$ histograma vermelho corresponde a expressão dos IgGs de cada molécula (controle negativo) e o azul o marcador investigado. Linha preta indica a delimitação de área referente a valores maiores do que o controle negativo.

Figura 23. Caracterização de células-tronco mesenquimais de medula óssea

\subsection{Transdução viral}

Não obtivemos sucesso na transdução viral com o vetor idealizado

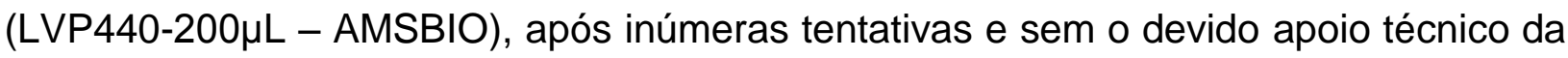
empresa. A empresa não possui representante no país e adquiriu o produto de outra empresa internacional, que o adquiriu da empresa produtora. Assim, concluímos que, possivelmente, ocorreram problemas de armazenagem do produto, inviabilizando a 
utilização do mesmo. Sendo assim, optamos por trocar de empresa, e, consequentemente, de vetor utilizado. Adquirimos o RediFect Red-Fluc-Puromycin (CLS960002, PerkinEImer), o qual superexpressa apenas a enzima luciferase (Luciola Itálica), possibilitando o rastreamento das células nos animais apenas pela luminescência.

\subsubsection{Luminescência In vitro}

Com o ensaio de viabilidade por MTT, observamos que a concentração mínima adequada de puromicina foi de $2 \mu \mathrm{g} / \mathrm{mL}$ (Figura 24).

\section{Curva Puromicina}

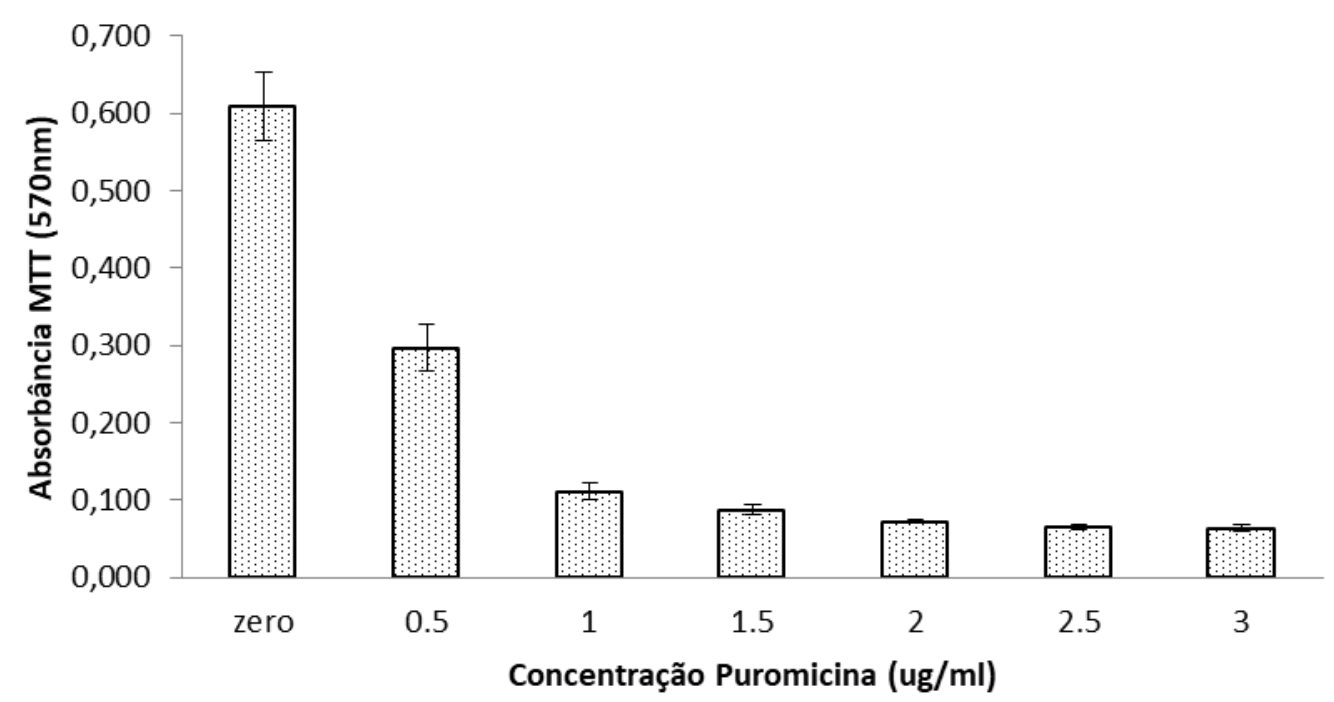

$\mathrm{N}=5$.

Figura 24. Curva de viabilidade celular por concentração de puromicina, detectados pela absorbância de MTT

Após seleção com puromicina e expansão das células, confirmamos a luminescência nas células, sendo o sinal proporcional à quantidade de células presente em cada poço (Figura 25). 
A

\section{Atividade Luminescência}

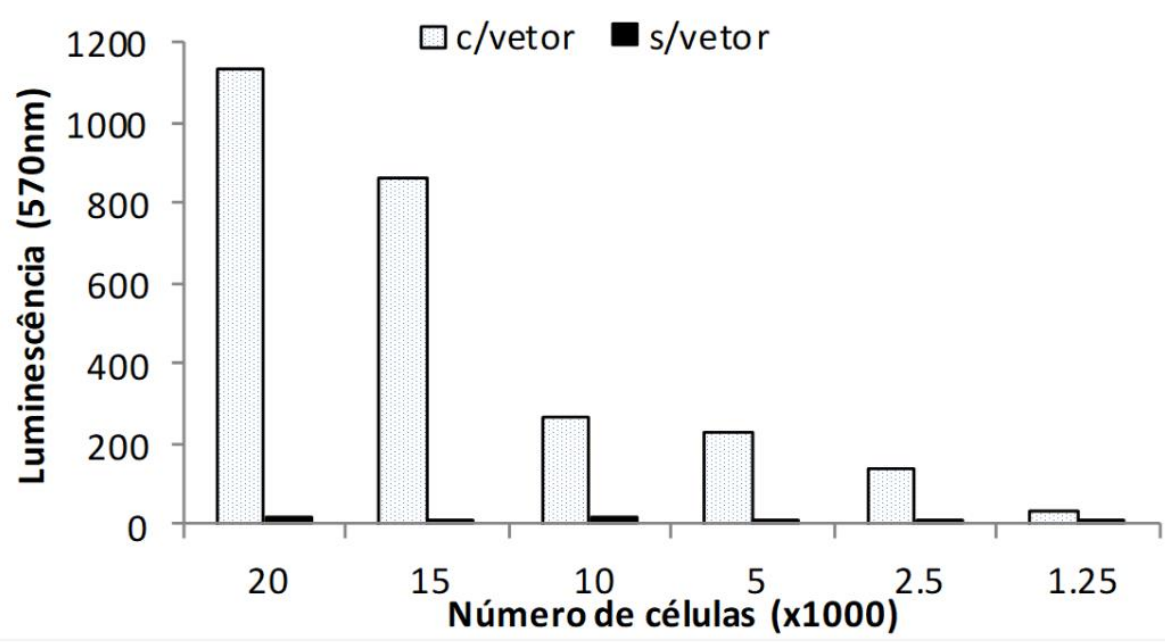

B

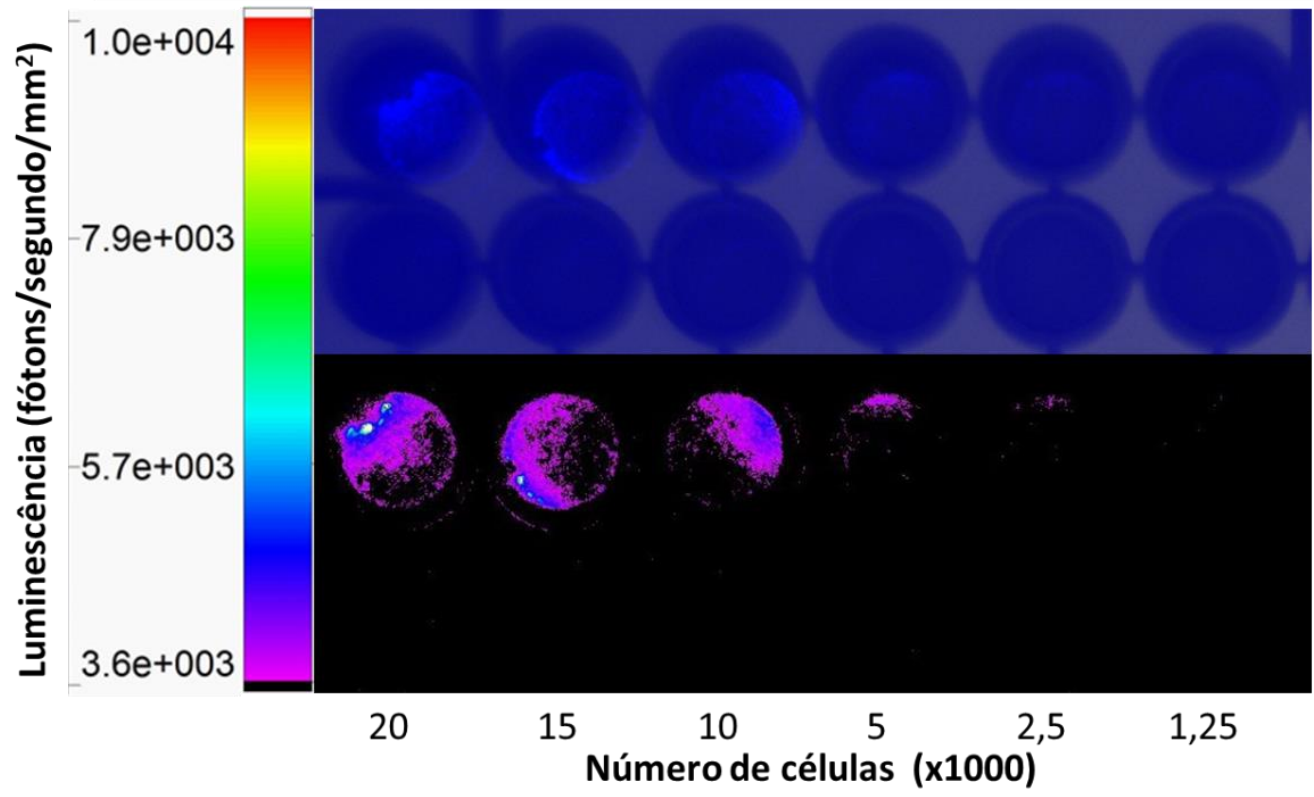

(A) Quantificação de luminescência $(570 \mathrm{~nm})$ produzida, comparando células com vetor e sem vetor. (B) Imagem superior mostra a sobreposição de imagens de luminescência e imagem de raio-x da placa, sendo primeira linha células com vetor e segunda linha sem vetor. Imagem inferior é a mesma imagem de intensidade de luminescência produzida pelas células, em escala colorimétrica arco-íris.

Figura 25. Ensaio de atividade de Luciferase in vitro

\subsubsection{Luminescência in vivo}

Os parâmetros de obtenção do sinal de luminescência, utilizados para detecção do sinal após IAt, não foram suficientes para observar o sinal das células, quando administradas via IVt (Figura 26). Após ajustes, determinamos os parâmetros ideais do equipamento a ambas as vias de transplante: tempo de três minutos de exposição da câmera; binning de dados de oito vezes; escala de 
intensidade colorimétrica "arco-íris". Isto possibilitou detectar as células no pulmão ex vivo oito horas após IVt (Figura 27).

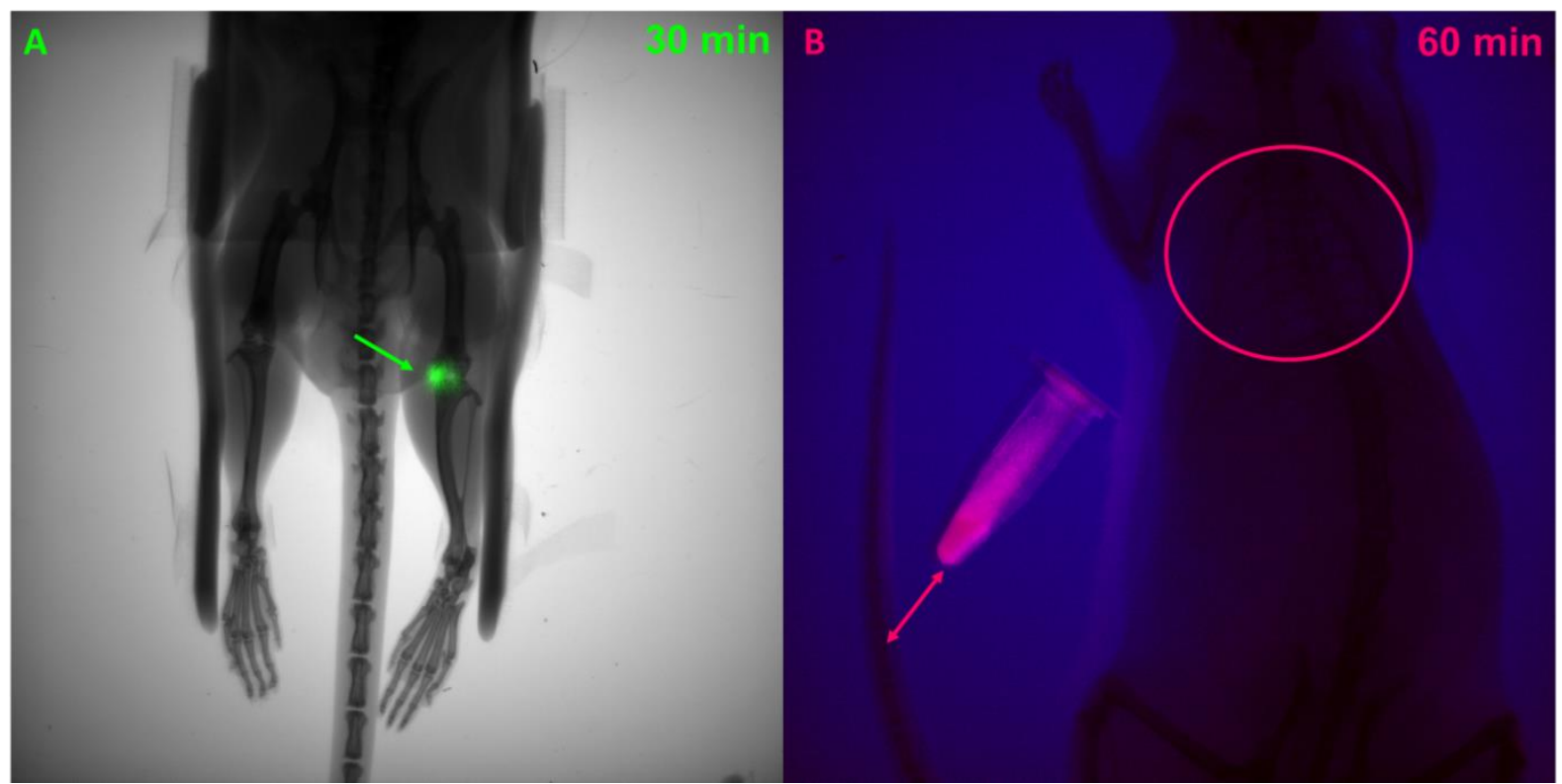

As imagens de luminescência estão sobrepostas a radiografia e em escala de cores. (A) 30 minutos após transplante intra-articular $(\mathrm{N}=1)$; seta verde indica localização do transplante e luminescência em escala de verde. (B) 60 minutos após transplante intravenoso $(\mathrm{N}=1)$; seta rosa indica quantidade de células injetadas e a localização do transplante; círculo rosa indica onde deveria ser possível observar o sinal das células transplantadas. Imagens adquiridas sem utilização de binning.

Figura 26. Avaliação da capacidade de detecção das células de acordo com a via de transplante

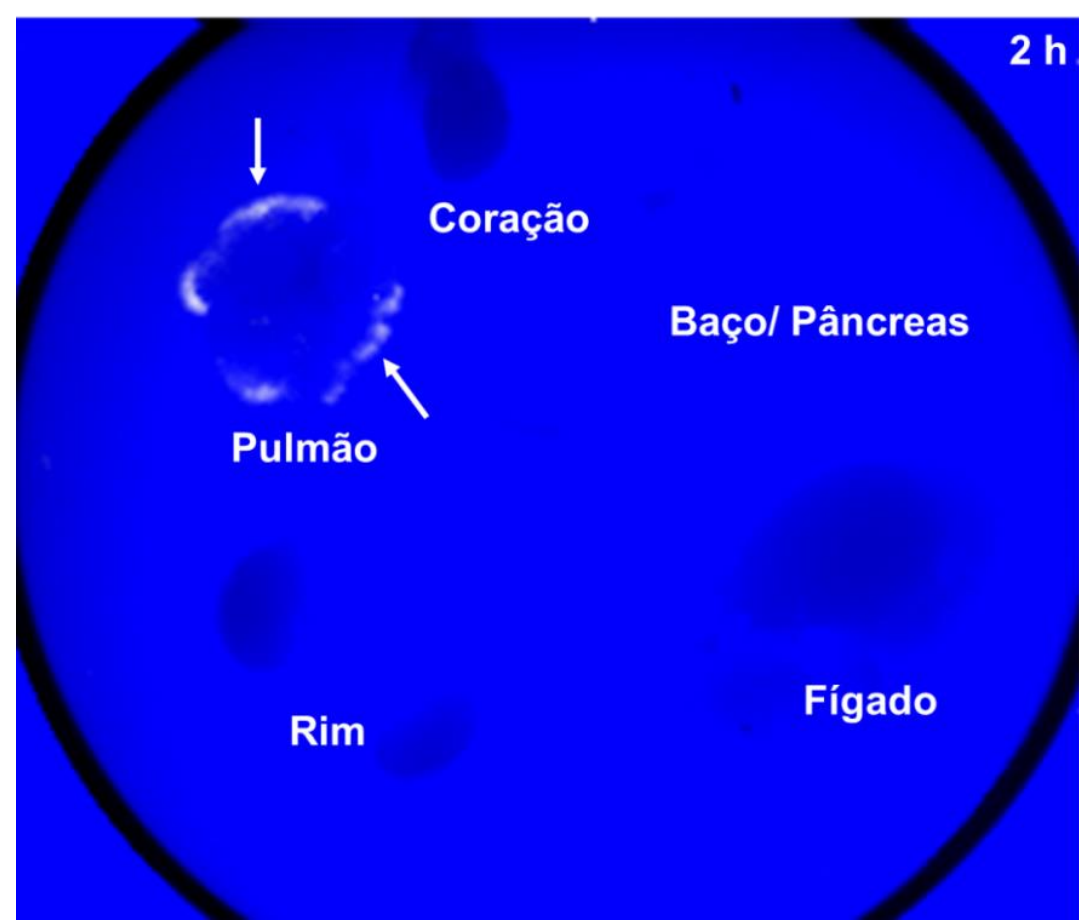

Setas brancas indicam a presença de células no pulmão, produzindo luminescência. Imagem com binning de oito vezes e escala de intensidade de cor branca. $\mathrm{N}=1$.

Figura 27. Avaliação do sinal de luminescência ex vivo duas horas após transplante intravenoso 
Valendo-se de tais parâmetros, realizamos a cinética da luciferina/luciferase ao IAt (Figura 28). Visando à análise qualitativa do homing das células, optamos por aumentar o número de células transplantadas, por via IVt de $2 \times 10^{6}$ células $/ \mathrm{kg}\left(\approx 4,5-5 \times 10^{5}\right.$ células), para $4 \times 10^{6}$ células $/ \mathrm{kg}\left(\approx 9-10 \times 10^{5}\right.$ células), o que permitiu observar as células in vivo e realizar a cinética luciferina/luciferase do IVt (Figura 29).
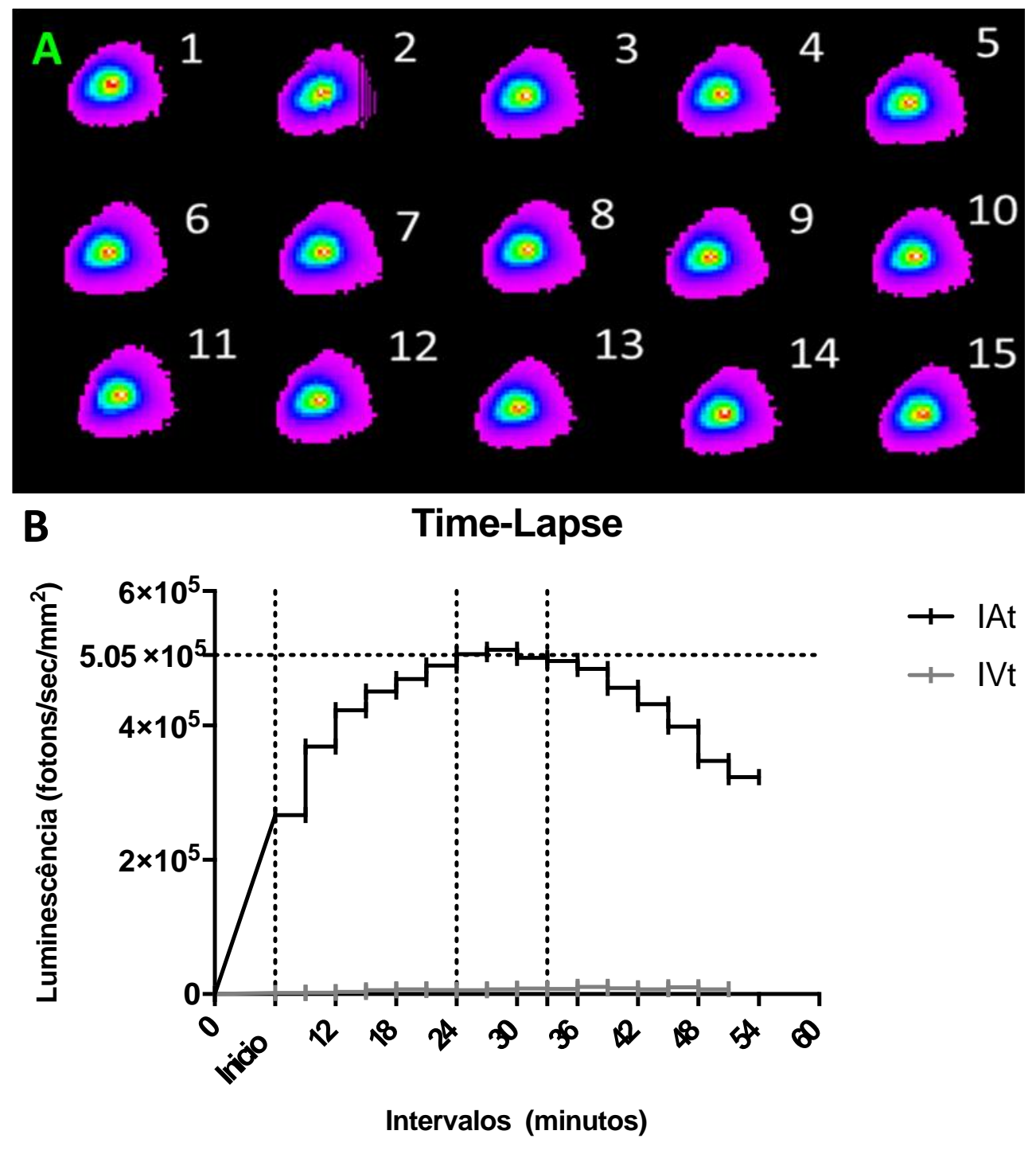

Imagem do sinal de luminescência obtido no joelho do animal, após administração intraperitoneal de luciferina $(A)$ e curva com os respectivos valores luminescência (B). IAt- Sinal de luminescência no animal, com transplante de células por via intraarticular. IVt- Sinal de luminescência no animal com transplante de células, por via intravenosa. Pontilhado vertical indica início da coleta, e a janela de melhor detecção de luminescência para o animal que recebeu IAt.

Figura 28. Cinética de luciferina/luciferase do transplante intra-articular 


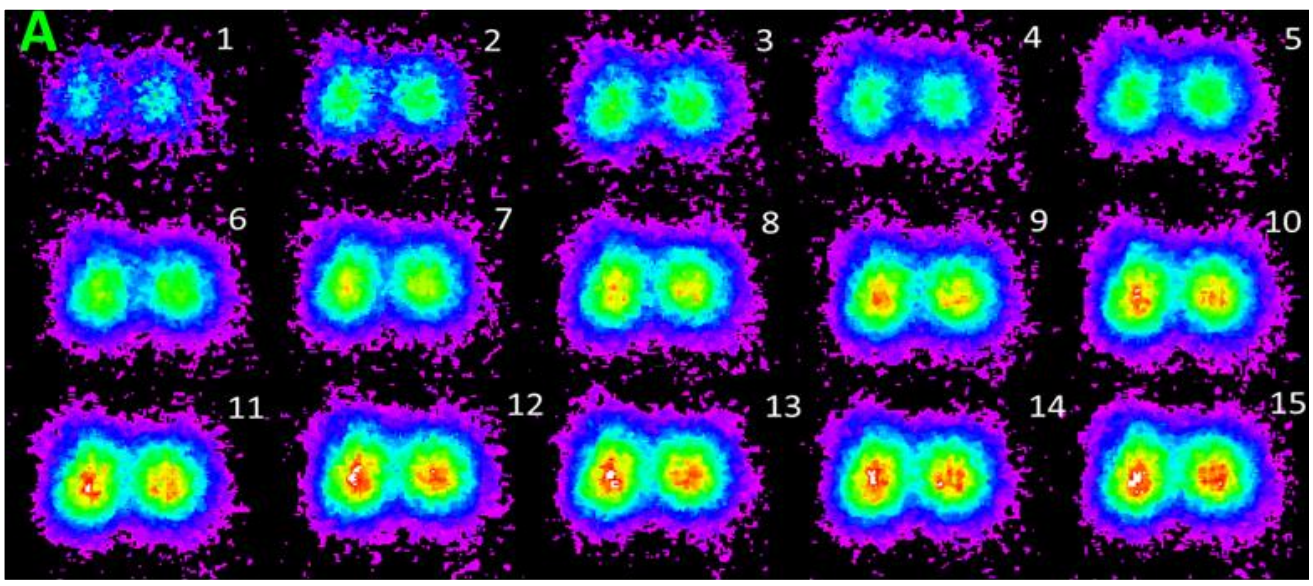

B

Time-Lapse

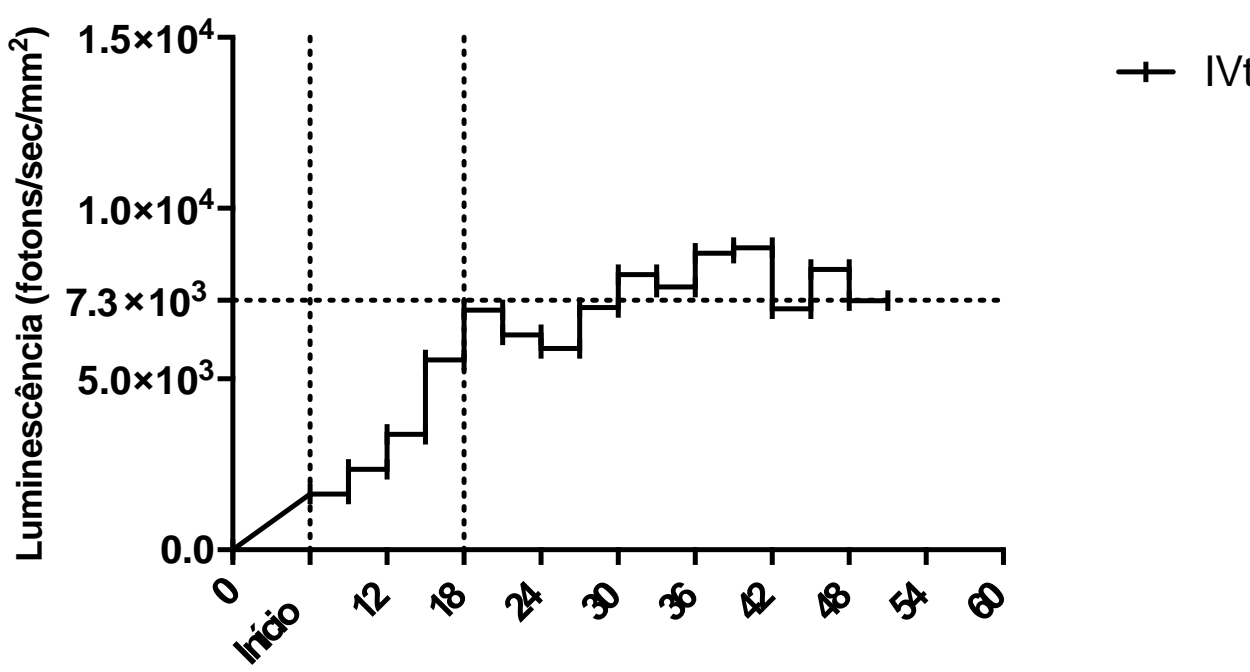

Intervalos (minutos)

Imagem do sinal de luminescência, obtido no pulmão do animal, após administração intraperitoneal de luciferina (A) e a curva com os respectivos valores de luminescência (B). IVt- Sinal de luminescência no animal com transplante de células, por via intravenosa. Pontilhado vertical indica início da coleta e ponto ideal de início da cinética, para mensuração da luminescência após IVt.

Figura 29. Cinética de luciferina/luciferase do transplante intravenoso

Para o transplante IA, a melhor "janela temporal" à detecção da luminescência foi de 26 a 33 minutos, após a administração de luciferina, enquanto ao transplante IV, o melhor tempo de detecção ocorreu, a partir de 18 minutos após a administração de luciferina (Figuras 28B e 29B). O sinal de luminescência mostrou-se menor para o IVt, mas foi suficiente para ser detectado pelo aparelho.

A figura 30 é representativa do gráfico de intensidade máxima de luminescência da figura 31. Esse sinal produzido por células viáveis, detectou-se em todos os animais, até uma semana após IAt $(\mathrm{N}=4)$.

Diferentemente da via IAt, os animais que receberam célula por via, IVt ( $\mathrm{N}=4)$ apresentaram, inicialmente, sinal de luminescência detectável no pulmão, 
apenas nas primeiras oito horas, sem qualquer detecção, após 24 horas do transplante. Em um único animal, foi possível observar sinal de luminescência na região do joelho acometido por OA, após 8H do IVt (Figura 30B).

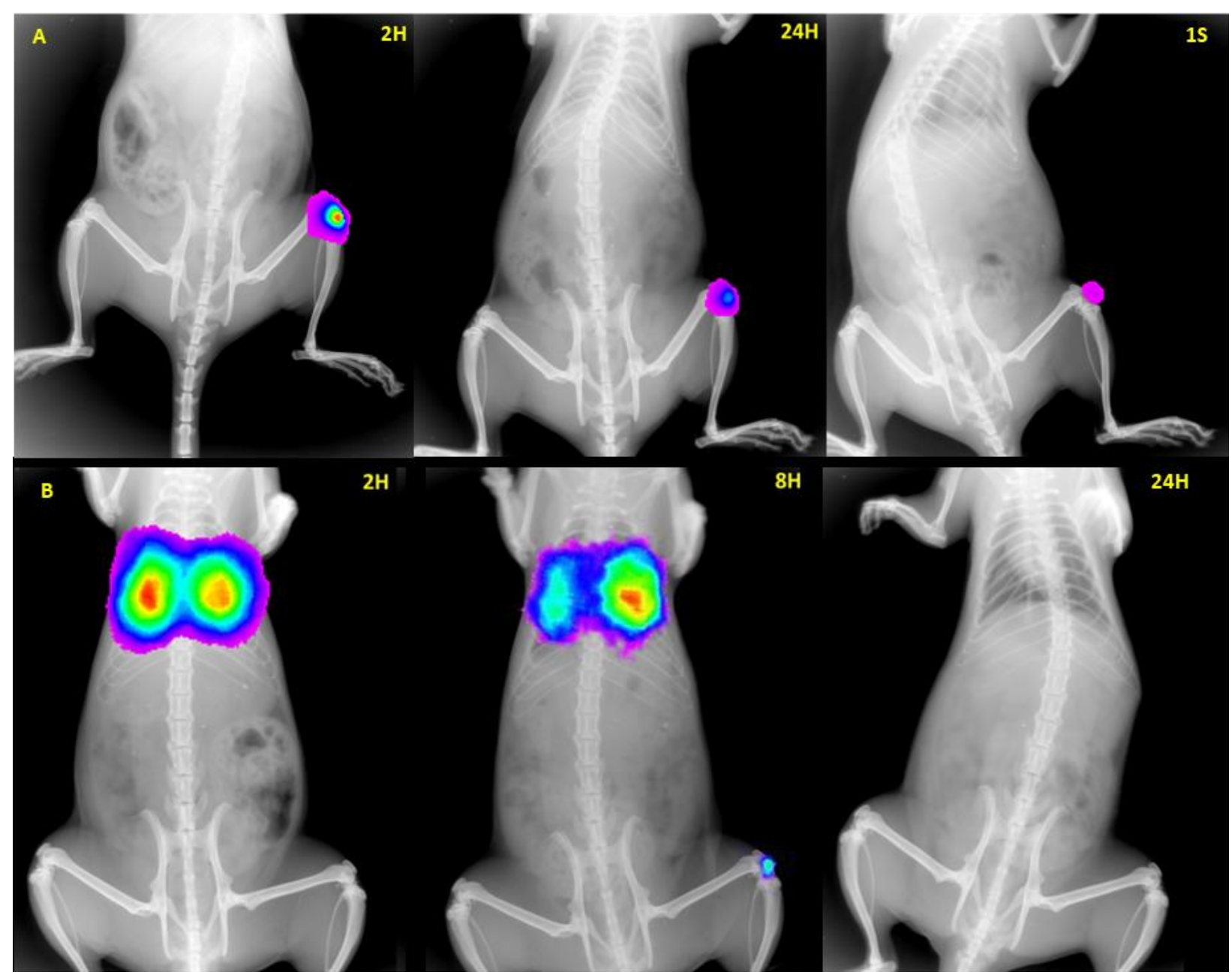

(A) Detecção do sinal após duas horas $(2 \mathrm{H}), 24$ horas $(24 \mathrm{H})$ e uma semana (1S) do transplante intraarticular de células-tronco mesenquimais. Imagem de luminescência sobreposta ao Raio-X do animal em decúbito ventral. (B) Detecção do sinal após duas $(2 \mathrm{H})$, oito $(8 \mathrm{H})$ e 24 horas $(24 \mathrm{H})$ do transplante intravenoso de células-tronco mesenquimais. Imagem de luminescência sobrepôs-se ao Raio-X do animal em decúbito dorsal.

Fonte: Adaptado de Dias de Oliveira FB, Antoniolli E, Souza JG, Dias OF, Ferretti M. Mesenchymal stromal cells tracking and cytokines kinetics following intra-articular and intravenous transplantation. Osteoarthritis Cartilage. 2019;27:S203-4. ${ }^{(105)}$

Figura 30. Sinal de luminescência, ao longo do tempo, após transplante intra-articular ou intravenoso

A intensidade do sinal de luminescência após IAt reduziu $57,98 \pm 17,22 \%$ e $93 \pm 8,38 \%$ em $24 \mathrm{H}$ e $1 \mathrm{~S}$, respectivamente, em relação ao ponto $2 \mathrm{H}$. O valor absoluto de luminescência encontrada no joelho (Figura 31), oito horas após IVt, foi similar a dois animais do grupo IAt em 1S (IVt-1: 1768; IAt-2: 1261,07; IAt-3: 1730,29 fótons $/ \mathrm{sec} / \mathrm{mm}^{2}$ ). 


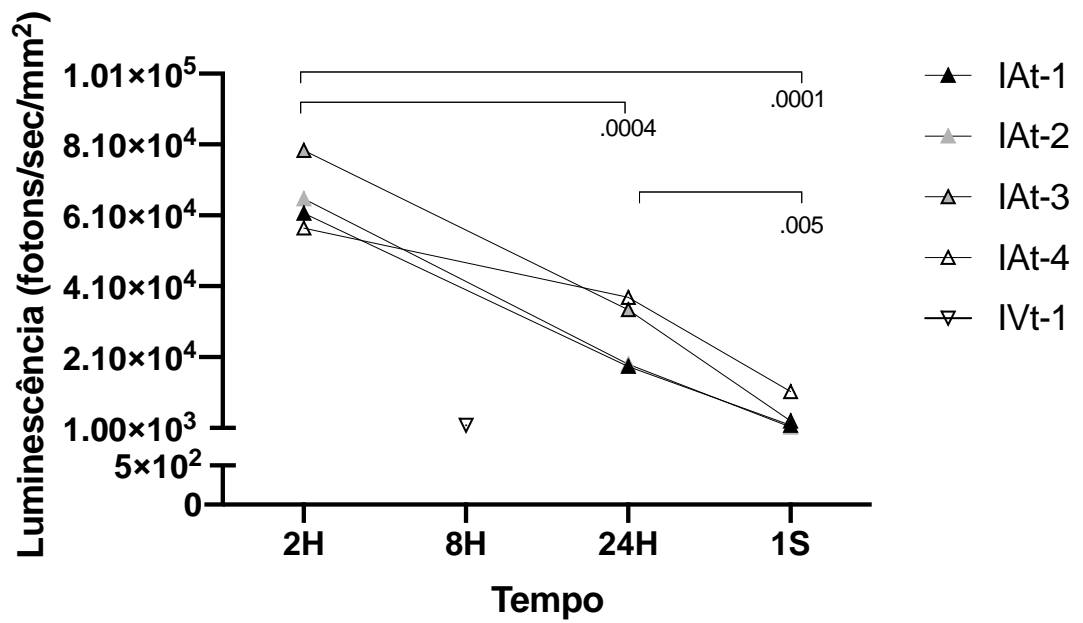

Detecção do sinal na articulação do joelho, após transplante celular intra-articular (IAt) e intravenoso (IVt). Tempos de análise: duas horas $(2 \mathrm{H}), 24$ horas $(24 \mathrm{H})$ e uma semana (1S), para quatro animais do grupo intra-articular (IAt-1, IAt-2, IAt-3, IAt-4) e oito horas $(8 \mathrm{H})$ para um animal do grupo intravenoso (IVt-1). Colchete preto: $p \leq 0,05$.

Figura 31. Intensidade máxima do sinal de luminescência, ao longo do tempo, após transplante intra-articular ou intravenoso

Analisando o delta da intensidade de luminescência entre os períodos de coletas, observa-se que, nas primeiras 24 horas após IAt $(2 \mathrm{H}-24 \mathrm{H})$, ocorreu uma redução mais evidente do sinal em comparação às modificações que aconteceram, nos dias subsequentes $(24 \mathrm{H}-1 \mathrm{~S})$. A normalização do delta entre coletas, em função do número de horas entre elas, evidencia essa questão (Figura 32), pois a redução do sinal por hora é maior, no período de $2 \mathrm{H}-24 \mathrm{H}$, em comparação com o período $24 \mathrm{H}-1 \mathrm{~S}$ e ao total $(2 \mathrm{H}-1 \mathrm{~S})$.

A

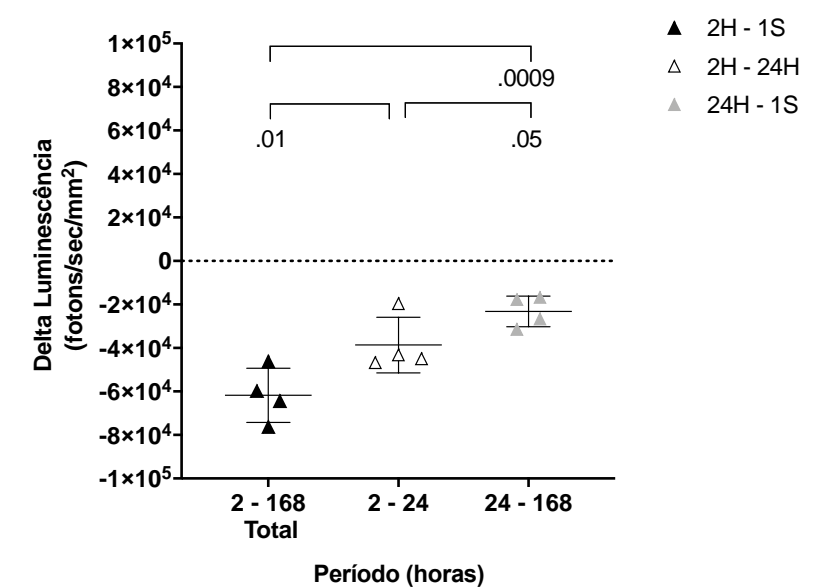

B

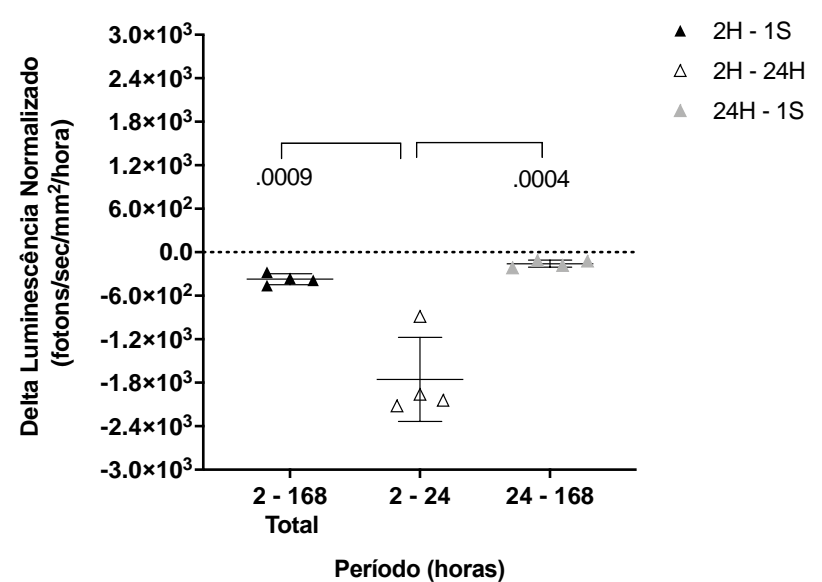

Detecção do sinal na articulação do joelho, entre coletas, após transplante celular intra-articular. Períodos analisados: duas horas a uma semana $(2 \mathrm{H}-1 \mathrm{~S})$, duas horas a 24 horas $(2 \mathrm{H}-24 \mathrm{H})$ e 24 horas a uma semana (24H-1S). (A) Análise de valores absolutos; (B) dados normalizados pelo período calculado em horas: 2-168 (166 horas), 2-24 (22 horas) e 24-168 (144 horas). Colchete preto: $p \leq 0,05$.

Figura 32. Delta entre tempos de coleta da intensidade máxima do sinal de luminescência 


\title{
3.2.3 Imunolocalização Anti-Luciferase
}

Devido a troca do vetor viral, utilizado no projeto, fez-se necessário buscar outro anticorpo para imuno-histoquímica da luciferase. Não encontramos, no mercado, um anticorpo específico à espécie de luciferase presente no nosso vetor viral, luciferase Luciola Italica. Segundo informações do fabricante, o anticorpo Anti-FireFly Luciferase Luciola cruciata (ab 187340; Abcam $^{\circledR}$ ) adquirido apresentava uma homologia de $81 \%$, com a espécie de luciferase do nosso vetor. Por tal motivo, realizamos uma imunocitoquímica inicial, a fim de avaliar a eficiência do anticorpo, em células transduzidas com o vetor. Obtivemos êxito na reação, e o anticorpo apresentou especificidade desejada (Figura 33).

Controle Negativo do Primário

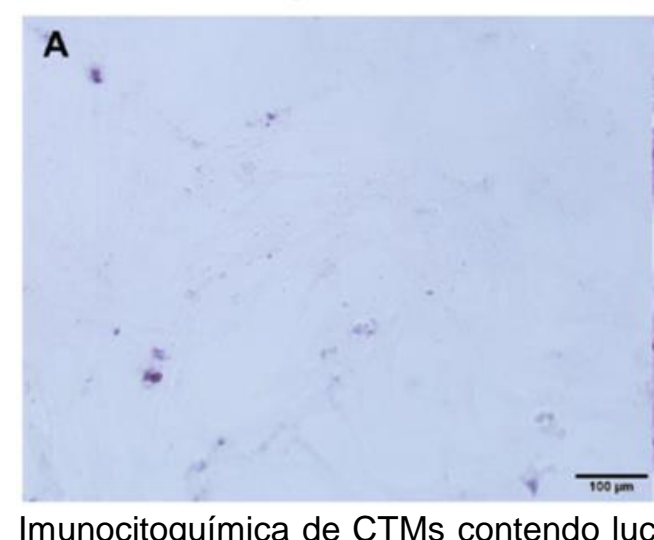

Imunocitoquímica de CTMs contendo luciferase, sem a presença do anticorpo $(A)$ e com a presença do anticorpo (B) contra Luciferase.

Figura 33. Imunocitoquímica Anti-FireFly Luciferase

Diluição 1/500

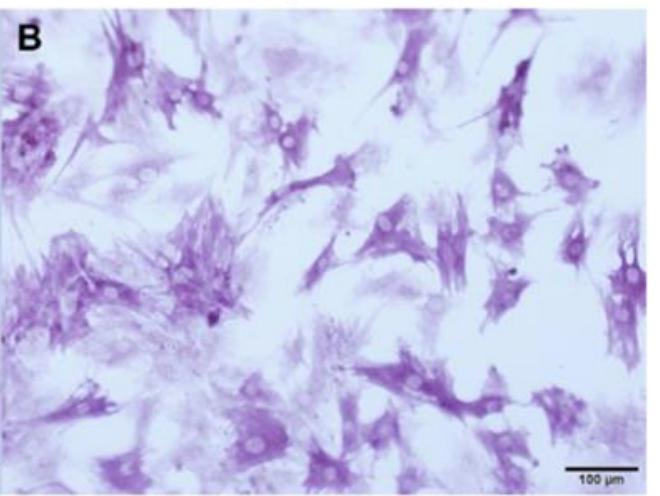

\section{A)}

\author{
(A)
}




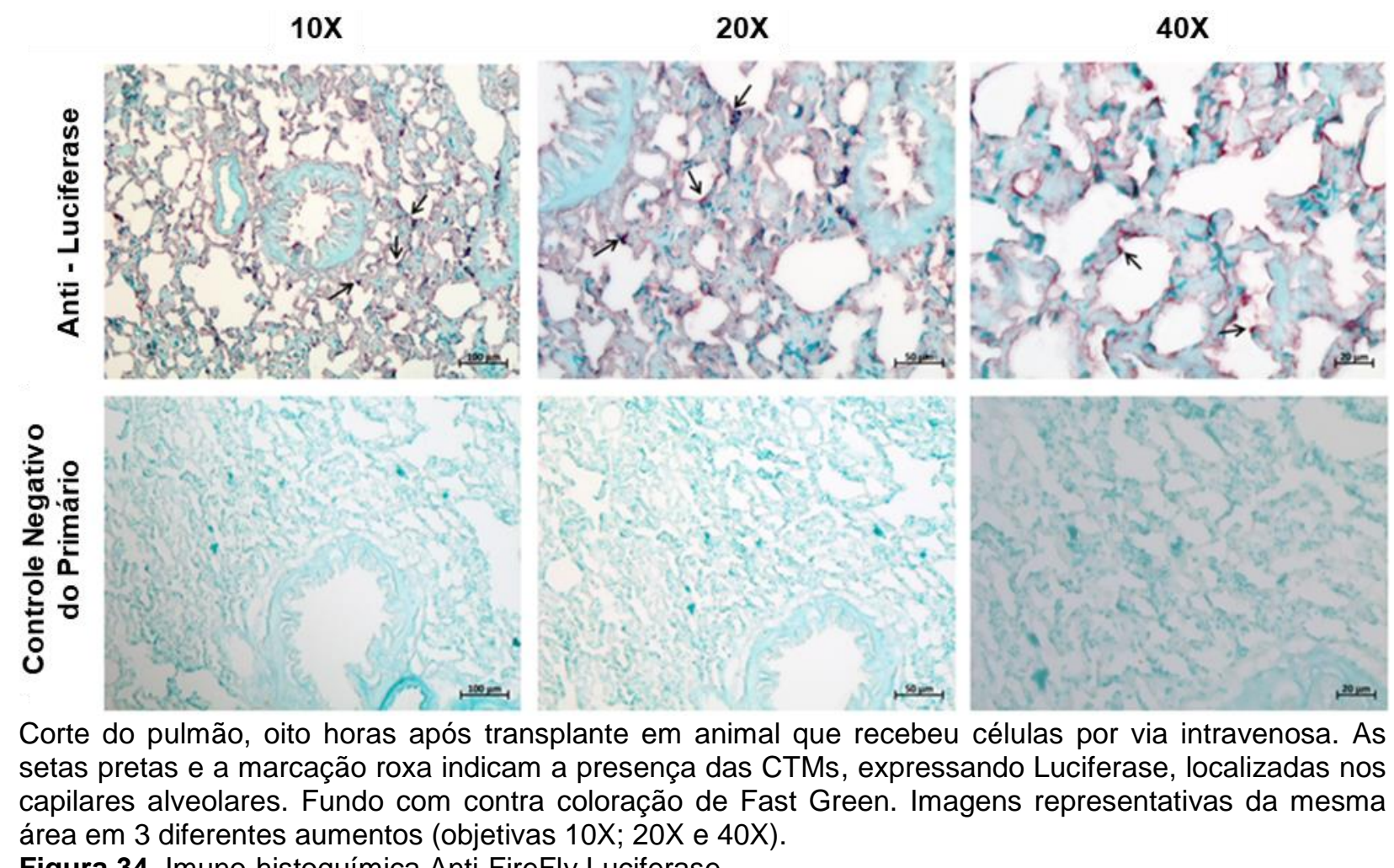

Figura 34. Imuno-histoquímica Anti-FireFly Luciferase

Após a confirmação da especificidade do anticorpo contra luciferase, realizamos vários testes nos cortes histológicos, em parafina do joelho de animais que receberam as células por IAt. Essas amostras provinham de animais, em que já havíamos observado a presença de células pelo ensaio de luminescência. Porém, embora tenhamos testado várias estratégias como: diferentes protocolos de recuperação antigênica, permeabilização, tempo de incubação e diluição de anticorpo, não conseguimos obter uma boa imagem do corte em parafina.

\subsection{Citometria de fluxo por imagem e microscopia confocal}

A marcação de membrana celular das CTMs e sua detecção pelo citômetro de imagem foram bem-sucedidas (Figura 35), possibilitando a visualização da morfologia dessas, antes de serem transplantadas.

A população total de células, utilizadas para definir a estratégia de gating e remoção de debris, encontra-se representada pela figura 36.

Fez-se possível detectar eventos positivos para a dupla marcação das CTMs (DiL e DiD), no pulmão e no joelho com OA, 12 horas após o transplante 
intravenoso (Figura 37). Possibilitou-se realizar a aquisição e análise das amostras de dois animais.

Os eventos adquiridos variam entre células inteiras e fragmentos de membrana celular. Na figura 38 ( $A, B$ e $C$ ) (tecido pulmonar) e na figura 39 ( $A, B$ e $C)$ (joelho com $O A$ ) encontram-se sinalizados pontos, com presença ou formação de fragmentos de membrana celular similares a vesículas, apesar de não ser possível identificar qual é o processo célula, efetivamente ocorrendo. As imagens D-E, de ambas as figuras, ilustram a presença de células, sem marcação aderidas as CTMs e/ou com fragmentos positivos em seu interior, indicando a presença de um processo de fagocitose destas.

$\mathrm{Na}$ imagem obtida pela microscopia confocal, do corte histológico do pulmão (Figura 40), é possível observar focos de aglomeração de CTMs, ao redor de estruturas alveolares. Interessantemente, também conseguimos identificar fragmentos de membrana celular marcada, similares aos observados pela citometria, no ambiente extracelular e ao entorno de algumas células.

A análise histológica por crio-corte não permitiu identificar a presença de CTMs nas estruturas do joelho com OA. Utilizando, então, a peça histológica completa da cartilagem do platô tibial (Figura 8E) e posicionando a parte superior (superfície articular) para cima, sobre uma lâmina histológica, escaneamos pontos aleatórios. A figura 41 representa um dos pontos escanados, em que é possível observar sinais positivos para marcação de membrana das CTMs. Contudo, não é possível, por essa imagem, identificar a orientação espacial das CTMs no tecido em questão. 


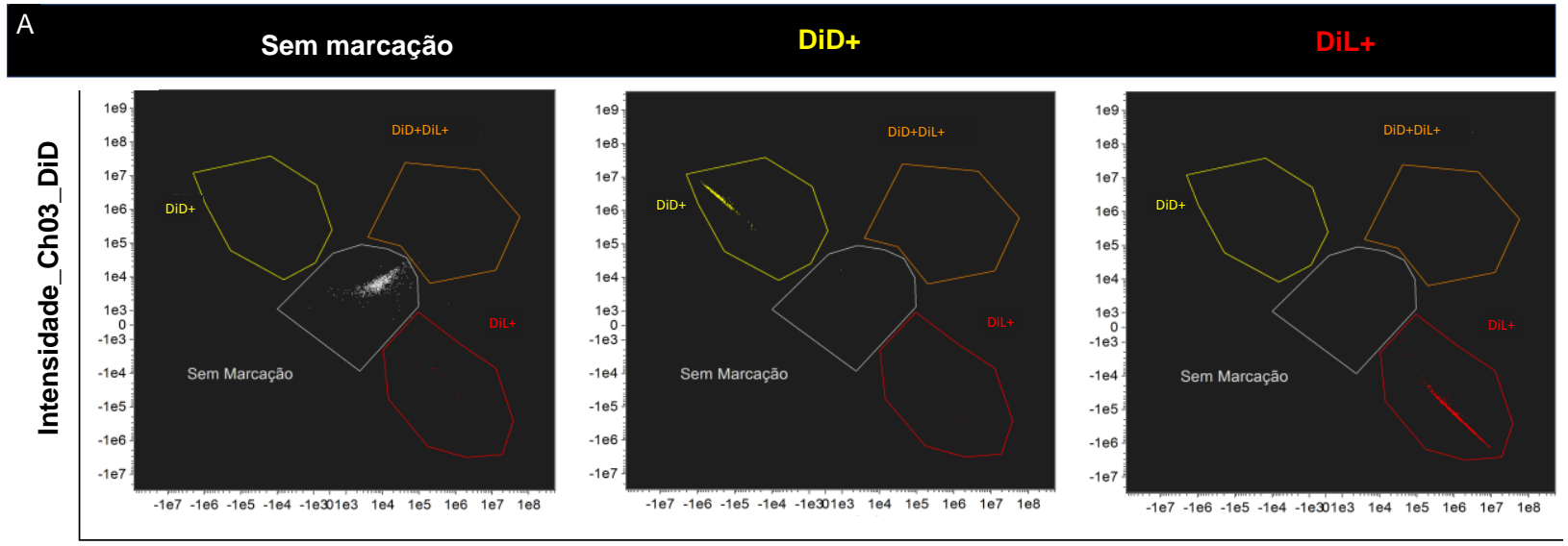

Intensidade_Ch11_DiL

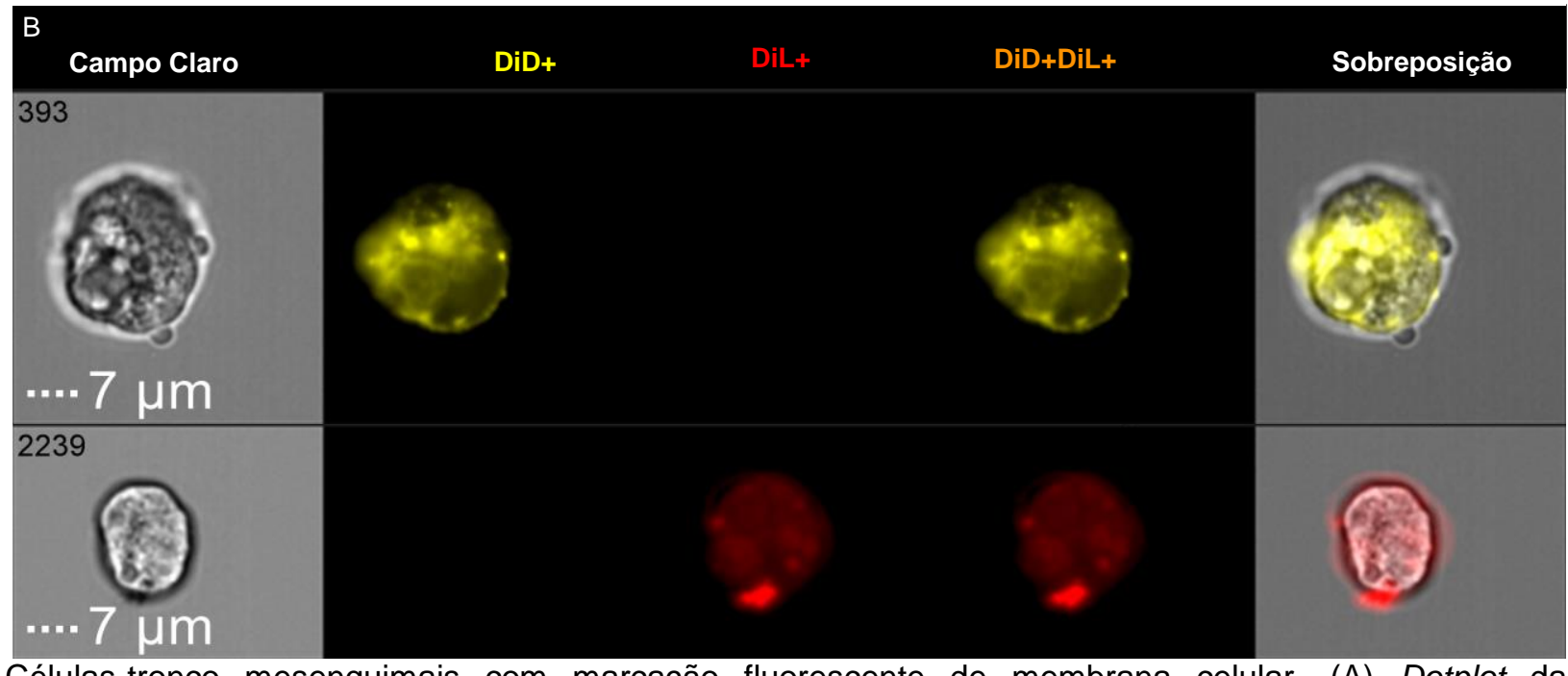

Células-tronco mesenquimais com marcação fluorescente de membrana celular. (A) Dotplot da estratégia de gating para células sem marcação (pontos brancos), células DiL positivas (pontos vermelhos) e DiD positivas (pontos amarelos). (B) Imagem de eventos celulares com marcação simples de DiD ou DiL.

Figura 35. Controle experimental da citometria de fluxo por imagem 

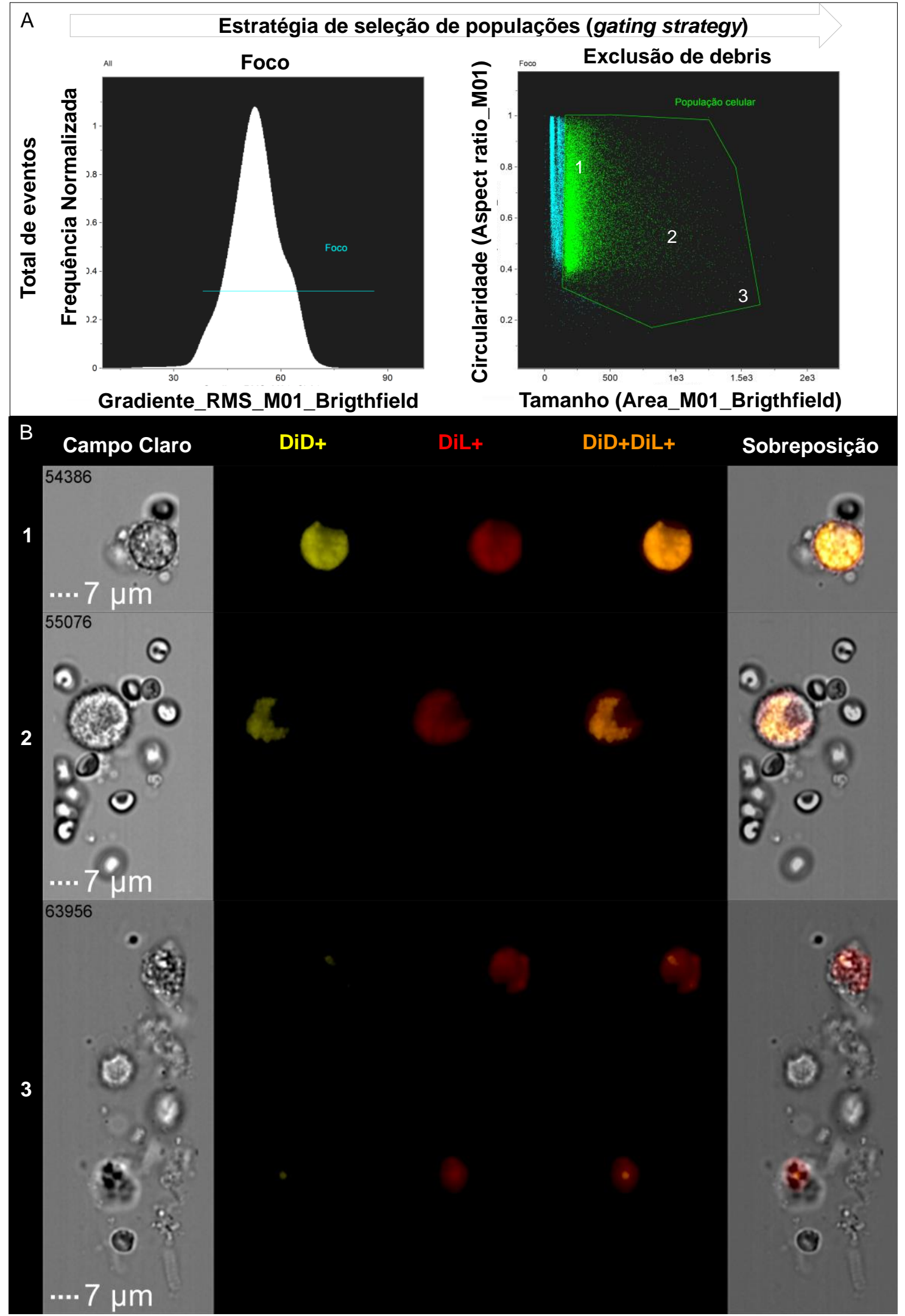

União dos eventos obtidos em todos tecidos e amostras do experimento. (A) Estratégia de gating para excluir debris (pontos brancos) da amostra total de eventos (pontos brancos e pontos verdes). (B) Imagem de eventos celulares de acordo com a região $(1,2$ ou 3) em que o evento está dentro do gate utilizado.

Figura 36. Estratégia de seleção da população de eventos, a ser analisada na citometria de fluxo por imagem 


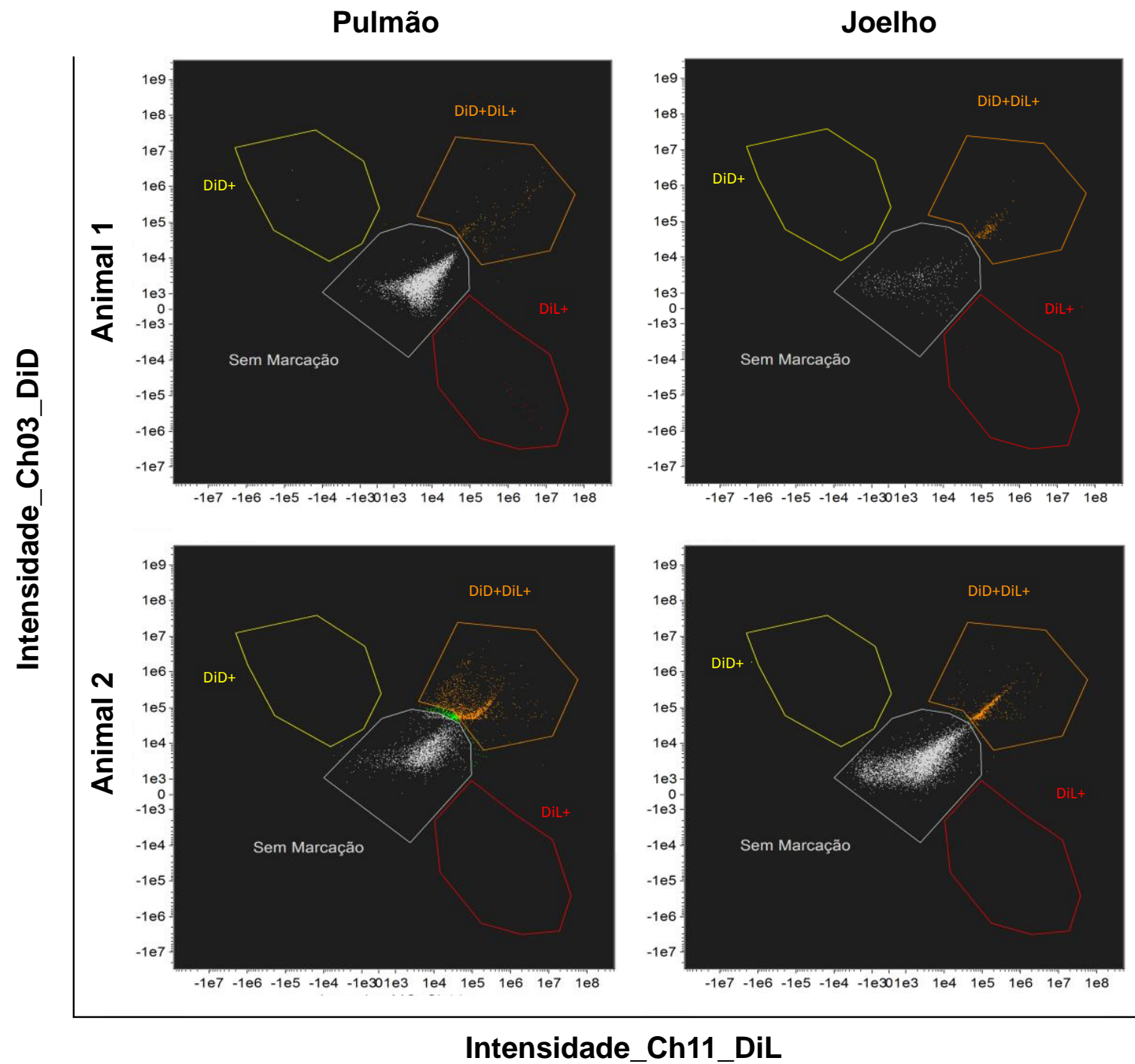

Marcação fluorescente (DiL+DiD+) de membrana celular em células-tronco mesenquimais, 12 horas após transplante intravenoso, no tecido pulmonar e no joelho com desestabilização do menisco medial. $\mathrm{N}=2$.

Figura 37. Dotplot da identificação de eventos duplo positivos, na citometria de fluxo por imagem 


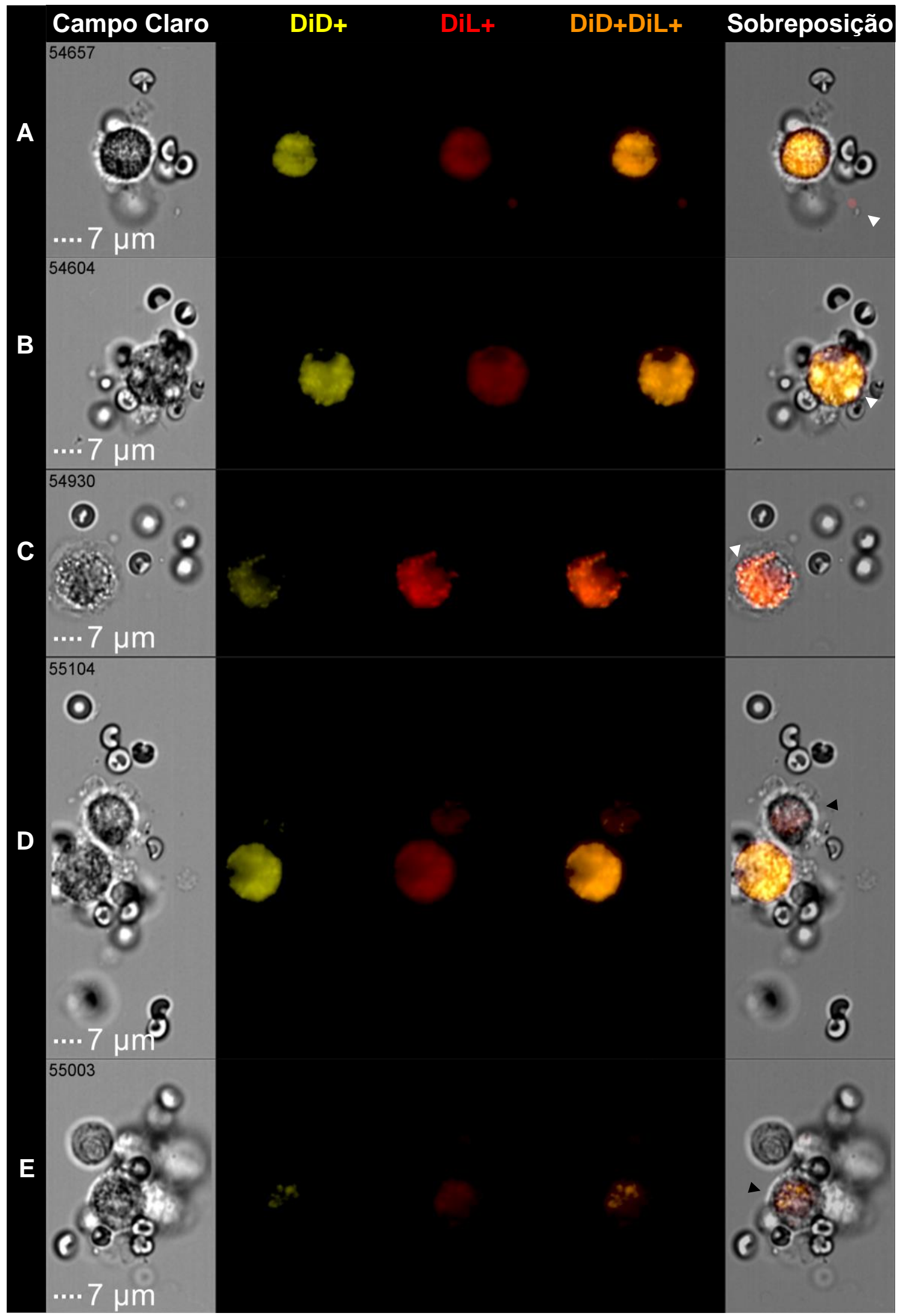

Doze horas, após transplante intravenoso de células-tronco mesenquimais com marcação fluorescente. Seta Branca - Indica partícula de membrana celular (A), ou formação de estruturas esféricas na membrana celular (B; C), similares a vesículas. Seta preta: Fragmentos de membrana celular, marcada no interior de células não pontuadas (D;E).

Figura 38. Imagens de eventos celulares obtidos da digestão do pulmão 


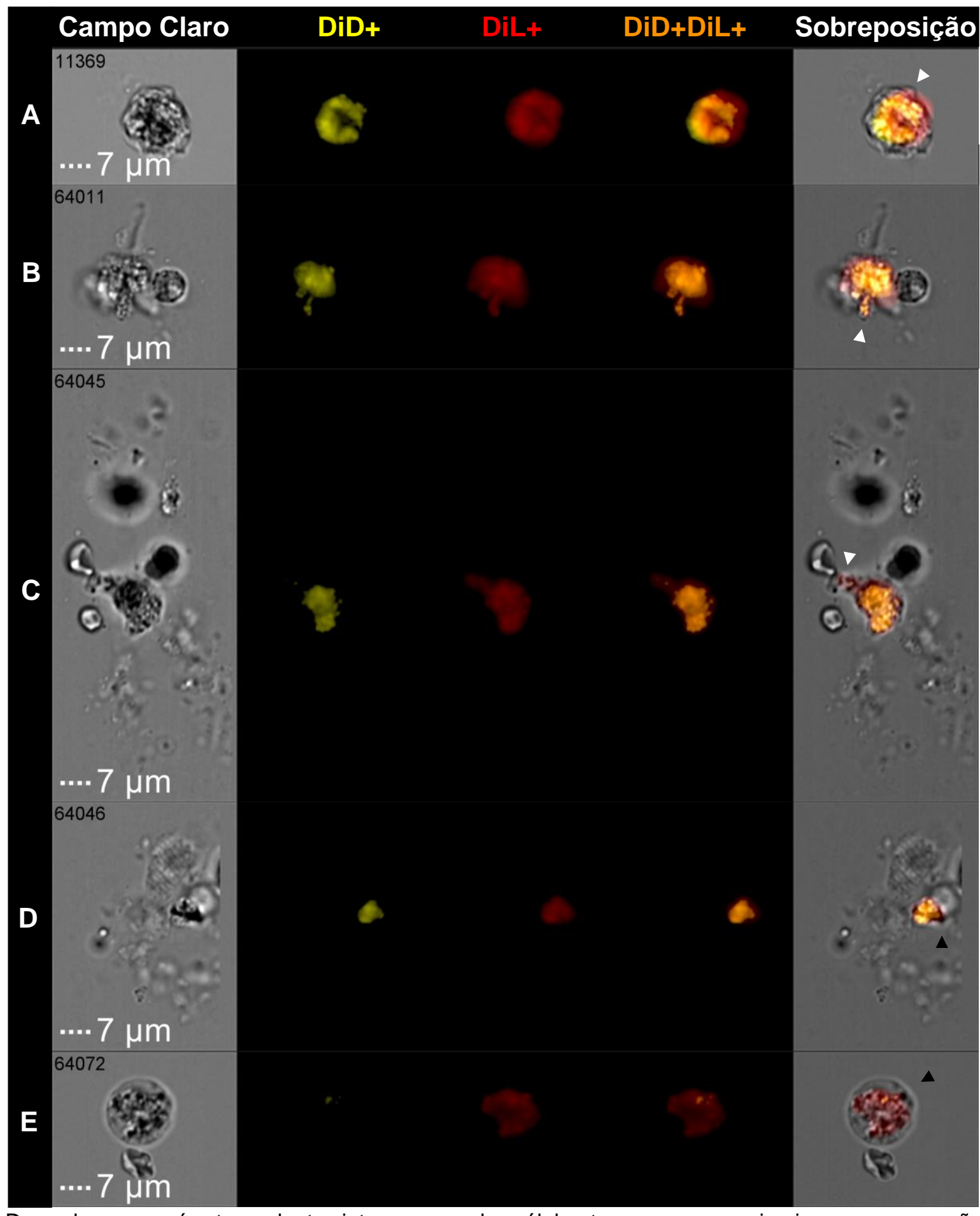

Doze horas, após transplante intravenoso de células-tronco mesenquimais com marcação fluorescente. Seta Branca - Indica formação de estruturas esféricas na membrana celular (A; B; C), similares a vesículas. Seta preta: Fragmentos de membrana celular marcada no interior de células não marcadas (D; E).

Figura 39. Imagens de eventos celulares, obtidos da digestão do joelho com desestabilização do menisco medial 


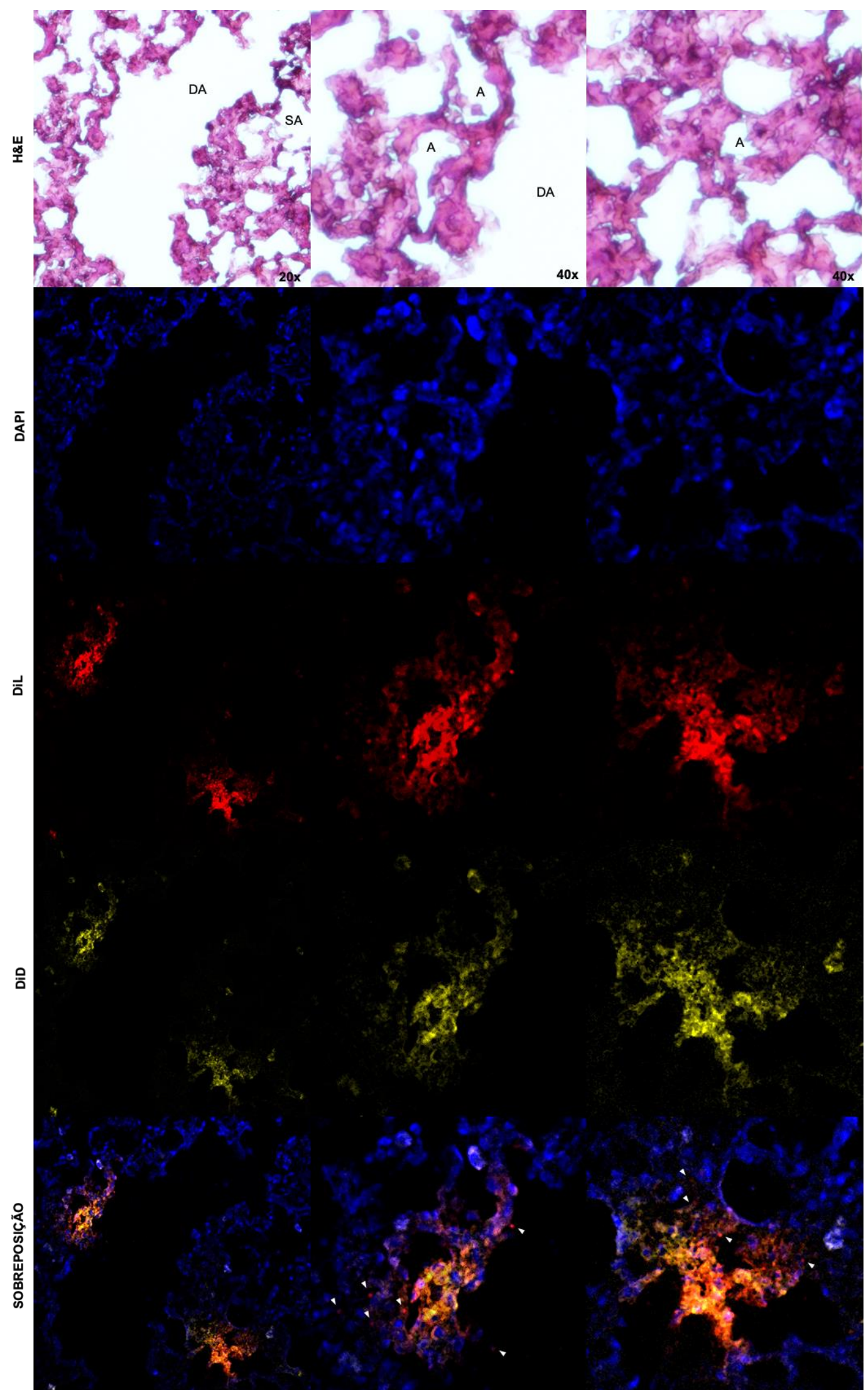

(A) Alvéolo; DA: Ducto Alveolar; SA: Saco Alveolar; H\&E: Hematoxilina e Eosina; DAPI: Núcleo celular; DiL/DiD: Célula-tronco mesenquimal; Seta branca: Fragmentos de membrana celular.

Figura 40. Tecido pulmonar, 12 horas após o transplante celular intravenoso com marcação fluorescente de membrana celular 


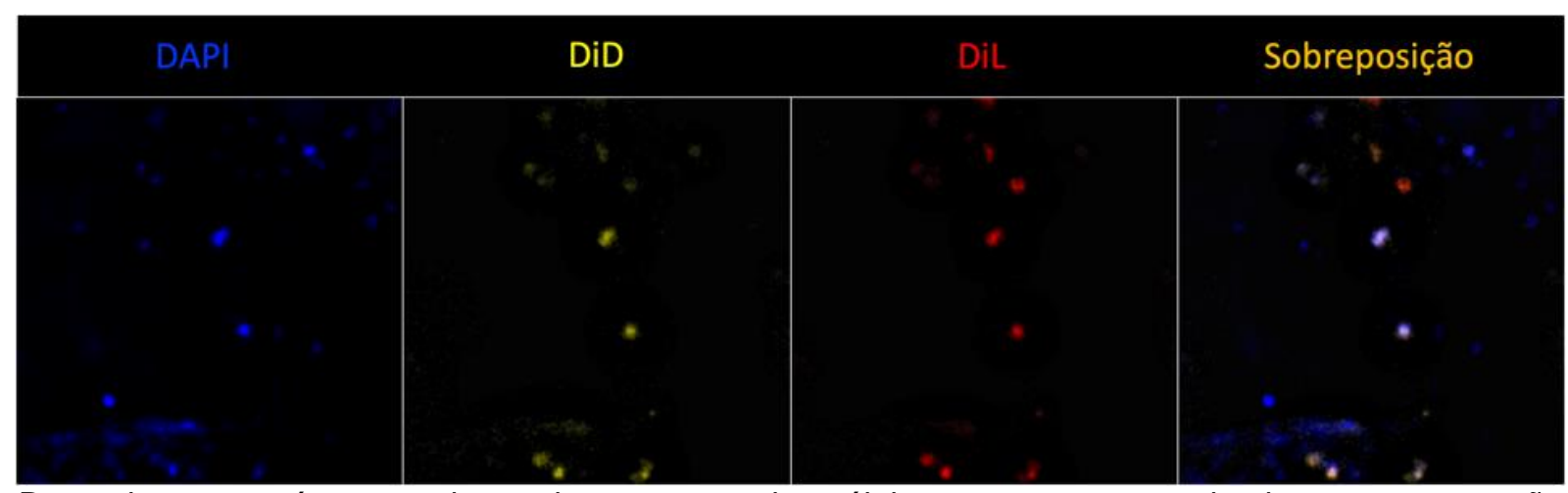

Doze horas, após transplante intravenoso de células-tronco mesenquimais com marcação fluorescente. Imagem de microscopia confocal com aumento de $20 x$, de um ponto aleatório na superfície da cartilagem. DAPI: Núcleo celular; DiL/DiD: Célula-tronco mesenquimal.

Figura 41. Visão superior de microscopia confocal da cartilagem articular do joelho, removida do platô tibial

\subsection{Análise morfológica e funcional do modelo animal de osteoartrose gerado por cirurgia de desestabilização do menisco medial}

\subsubsection{Peso e equilíbrio muscular}

Entre os músculos avaliados do grupo $\mathrm{CON}$, o tibial anterior e gastrocnêmio/sóleo do MIOA apresentaram pesos menores, quando comparados aos respectivos músculos do MICL, em 13 e 21 semanas após a cirurgia DMM. O quadríceps apresentou a mesma diferença entre MI, porém, apenas 21 semanas após a cirurgia (Figura 42). A média da diferença percentual entre MIOA e MICL do tibial anterior foi a menor entre os três músculos, em 13 semanas (tibial anterior: $-3,685 \pm 2,806 \%$; gastrocnêmio e sóleo: $-1,842 \pm 2,028 \%$; quadríceps: $-0,4389 \pm 1,377 \%$ ) e 21 semanas (tibial anterior: $-3,521 \pm 2,126 \%$; gastrocnêmio e sóleo: $-2,677 \pm 1,867 \%$; quadríceps: $-1,722 \pm 1,778 \%$ ). Porém, a comparação da diferença percentual foi, estatisticamente, significante apenas para o tibial anterior, em relação ao quadríceps, 13 semanas após a cirurgia DMM $(p=0,008)$. 
A
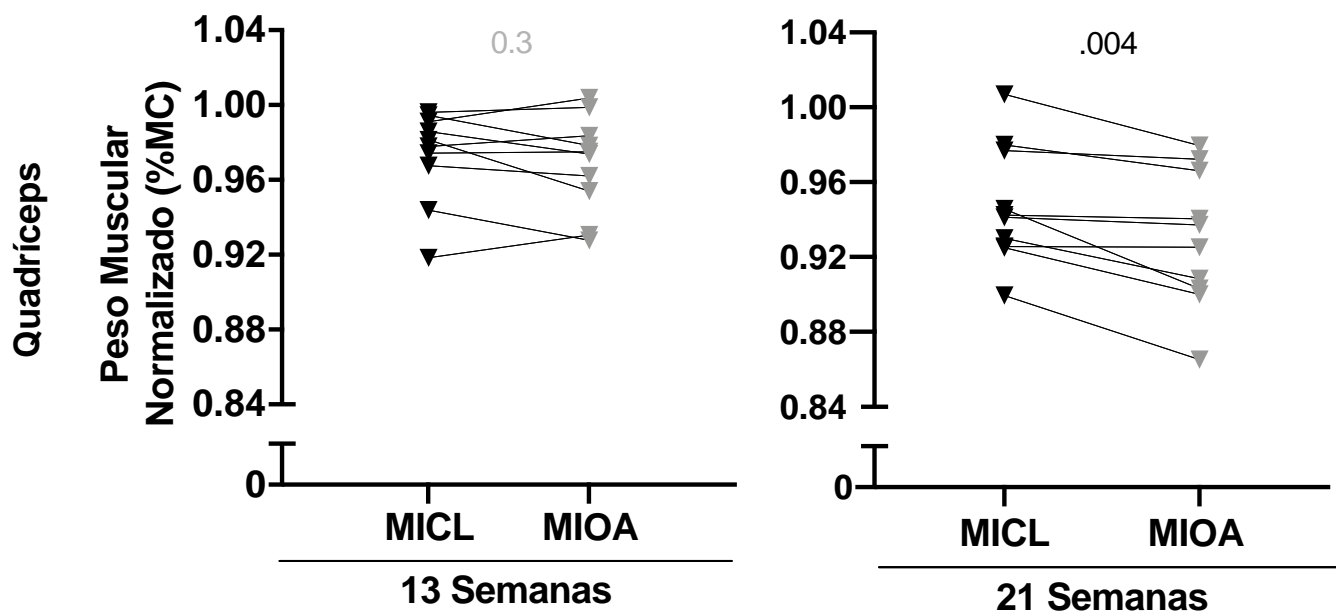

B
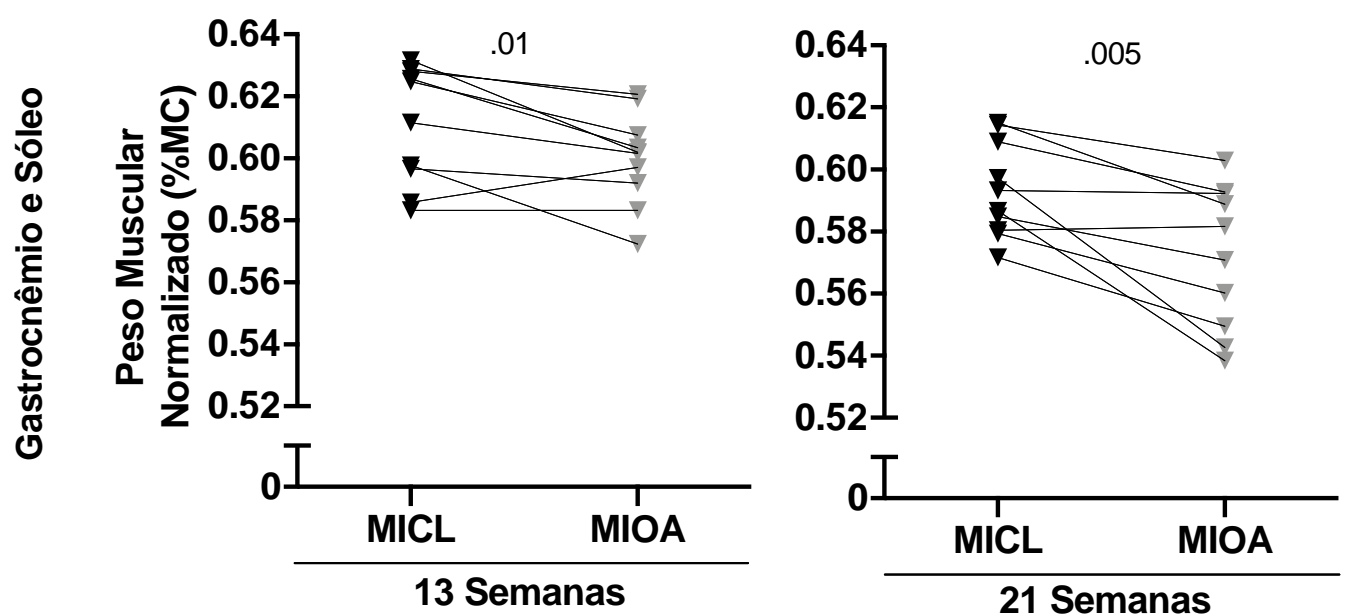

C
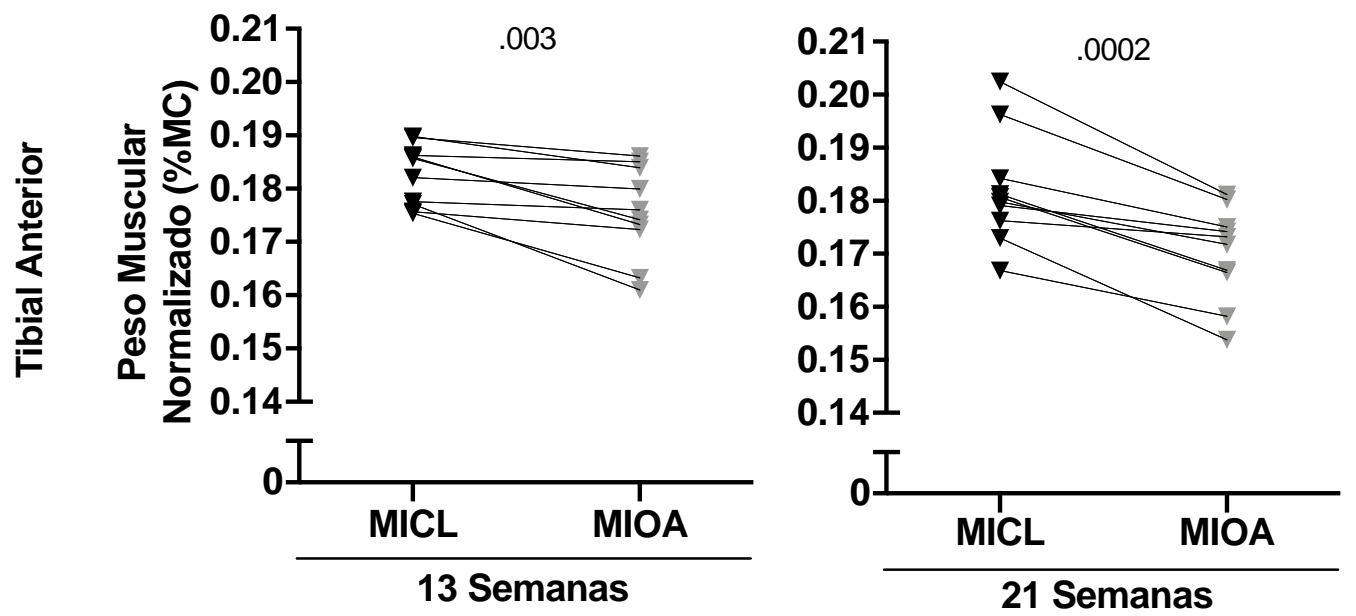

Razão (\%) entre o peso muscular (gramas) do membro inferior operado (MIOA) ou contralateral (MICL) e a massa corporal (MC) (gramas) do animal, 13 (13S) e 21 (21S) semanas, após desestabilização do menisco medial (DMM), para o grupo controle (CON). Valores em preto: $p \leq 0,05$; Valor em cinza: $p>0,05 ; N=10$.

Figura 42. Peso muscular normalizado pela massa corporal 
Ao realizar a análise entre grupos do equilíbrio muscular, identificamos que aqueles, com intervenção SHAM+CTM,12 semanas após IAt (para quadríceps e gastrocnêmio/sóleo) e 12 semanas após IVt (para gastrocnêmio/sóleo), apresentaram maior equilíbrio muscular, em comparação com os DMM+PLACEBO e DMM+CTM (Figura 43A e B) nas mesmas condições. Para o tibial anterior, os grupos com intervenção SHAM+CTM-IAt e DMM+CTM-IAt, apresentaram maior equilíbrio muscular do que o DMM+PLACEBO-IAt, quatro semanas após o transplante (Figura $43 C)$.

Para a comparação entre vias de transplante (IAt e IVt) utilizaram-se apenas os valores de equilíbrio muscular dos grupos DMM+CTM. O grupo que recebeu IAt, em quatro semanas, apresentou maior equilíbrio muscular do tibial anterior do que o grupo que recebeu IVt (Figura 44). Não houve diferenças entre IAt e IVt para nenhum dos outros músculos ou tempo de eutanásia. 
A

Quadríceps

$\mathrm{DMM}+\mathrm{PLACEBO} \triangle \nabla$ SHAM + CTM $\triangle \nabla \mathrm{DMM}+\mathrm{CTM}$

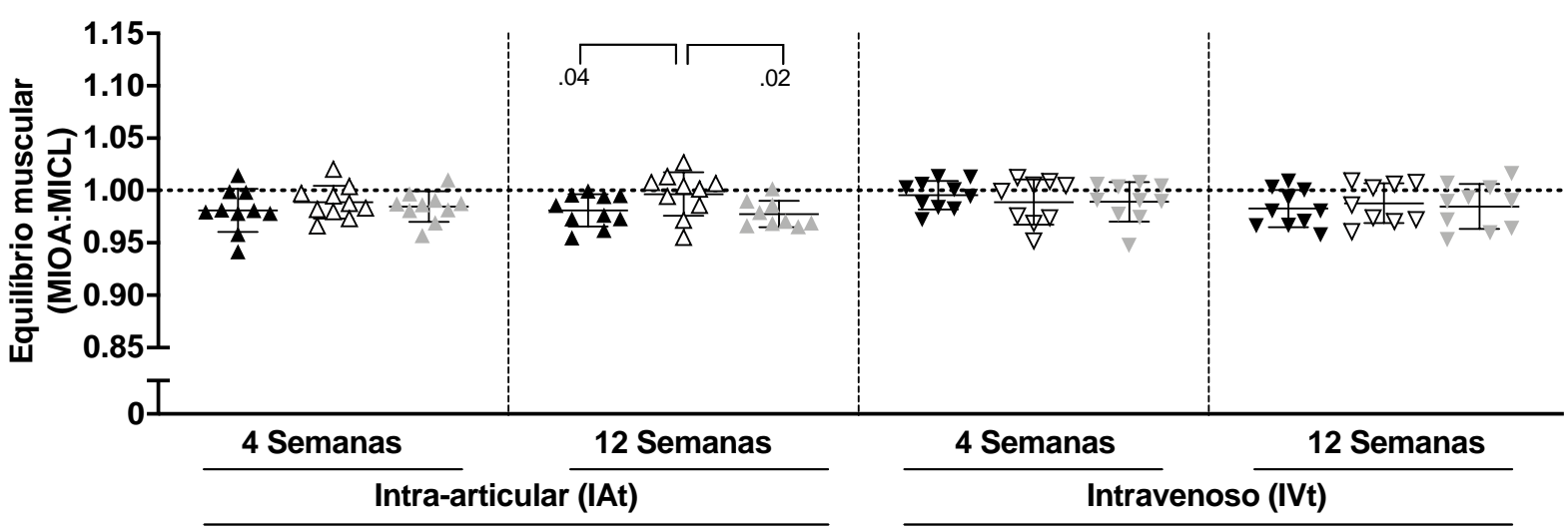

B

Gastrocnêmio e Sóleo

$\Delta \nabla \mathrm{DMM}+$ PLACEBO $\triangle \nabla$ SHAM + CTM $\Delta \nabla \mathrm{DMM}+\mathrm{CTM}$

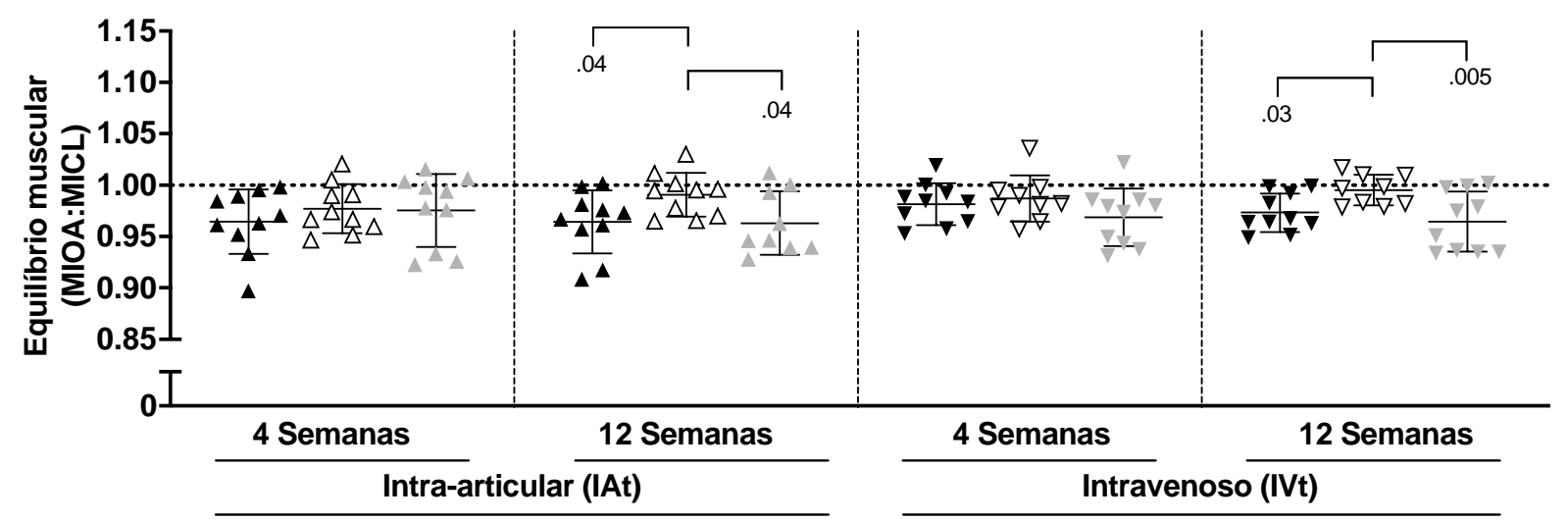

C

Tibial Anterior

$\Delta \nabla \mathrm{DMM}+\mathrm{PLACEBO} \quad \triangle \nabla \mathrm{SHAM}+\mathrm{CTM} \quad \Delta \nabla \mathrm{DMM}+\mathrm{CTM}$

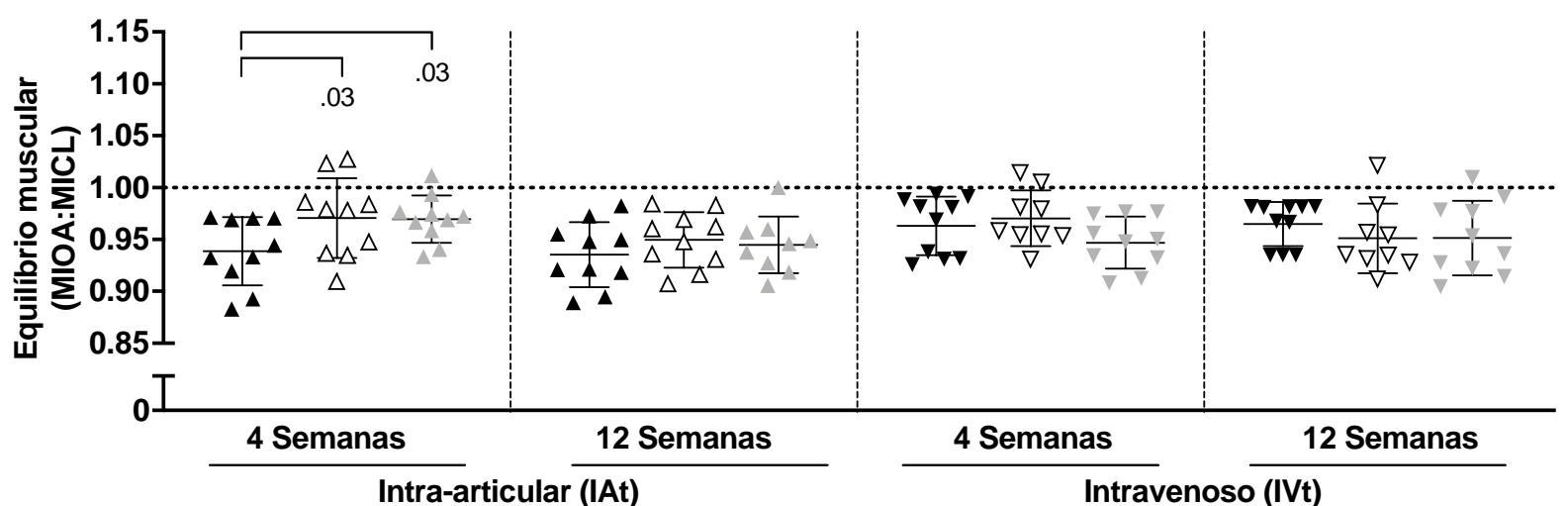

Cálculo realizado pela razão, entre o membro operado (MIOA) e o membro contralateral (MICL). Resultados de quatro e 12 semanas, após transplante intra-articular (IAt) ou intravenoso (IVt). Linha pontilhada no eixo " $y$ " representa o equilibro perfeito. Colchete: $p \leq 0,05$. DMM: desestabilização do menisco medial; PLACEBO: cloreto de sódio 0,9\%; SHAM: cirurgia sem desestabilização do menisco medial; CTM: célula-tronco mesenquimal.

Figura 43. Comparação do equilíbrio muscular de membros inferiores entre grupos 

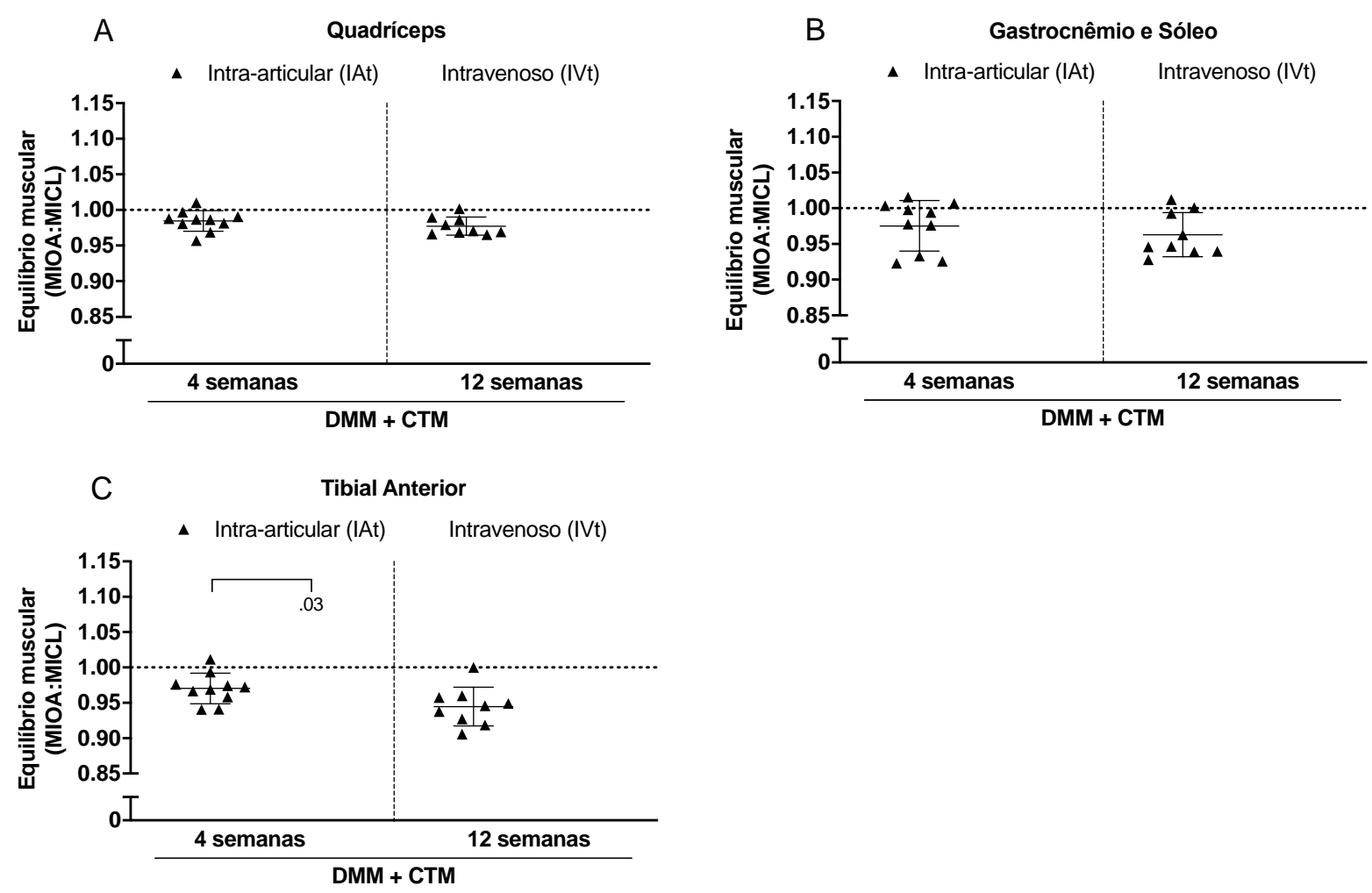

Cálculo realizado pela razão entre o membro operado (MIOA) e o membro contralateral (MICL). Resultados de quatro e 12 semanas, após transplante intra-articular (IAt) ou intravenoso (IVt). Linha pontilhada no eixo " $y$ " representa o equilibro perfeito. Colchete: $p \leq 0,05$; DMM: desestabilização do menisco medial; CTM: célula-tronco mesenquimal.

Figura 44. Comparação do equilíbrio muscular de membros inferiores entre vias de transplante

\subsubsection{Análise de marcha 2D}

Para determinar o padrão normal de marcha do rato, gerou-se uma nuvem de normalidade, a partir da média \pm desvio padrão da passada média de 22 animais. A média das passadas médias desses 22 animais foi utilizada para representar a normalidade da marcha. Não observamos alterações no padrão da marcha dos animais, após a instalação da OA pelo modelo de DMM, uma vez que sua curva média, com OA, encontra-se dentro da nuvem de normalidade, próxima da curva média de normalidade (Figuras 45, 46 e 47) e da curva média do grupo SHAM. Da mesma forma, não observamos diferença estatística na frequência e amplitude de passada (Tabela 3) entre as intervenções DMM e SHAM, com relação à normalidade (Pré-cirurgia). 
Tabela 3. Frequência e amplitude de passada antes e nove semanas após DMM

\begin{tabular}{lcc} 
Teste & $\begin{array}{c}\text { Frequência } \\
\text { (passadas/min) }\end{array}$ & $\begin{array}{c}\text { Amplitude } \\
\text { (cm) }\end{array}$ \\
\hline Pré-cirurgia & $133,79 \pm 10,33$ & $13,23 \pm 2,08$ \\
DMM & $132,31 \pm 13,79$ & $13,95 \pm 2,22$ \\
SHAM & $127,16 \pm 8.69$ & $14,47 \pm 1,53$ \\
\hline Pré & $127,2)$ & DMM: nove
\end{tabular}

Pré-cirurgia: antes da cirurgia de desestabilização do menisco medial ( $\mathrm{N}=22)$; DMM: nove semanas após cirurgia $(\mathrm{N}=17)$; SHAM: nove semanas após cirurgia placebo sem rompimento do ligamento menisco-tibial medial $(\mathrm{N}=7)$.

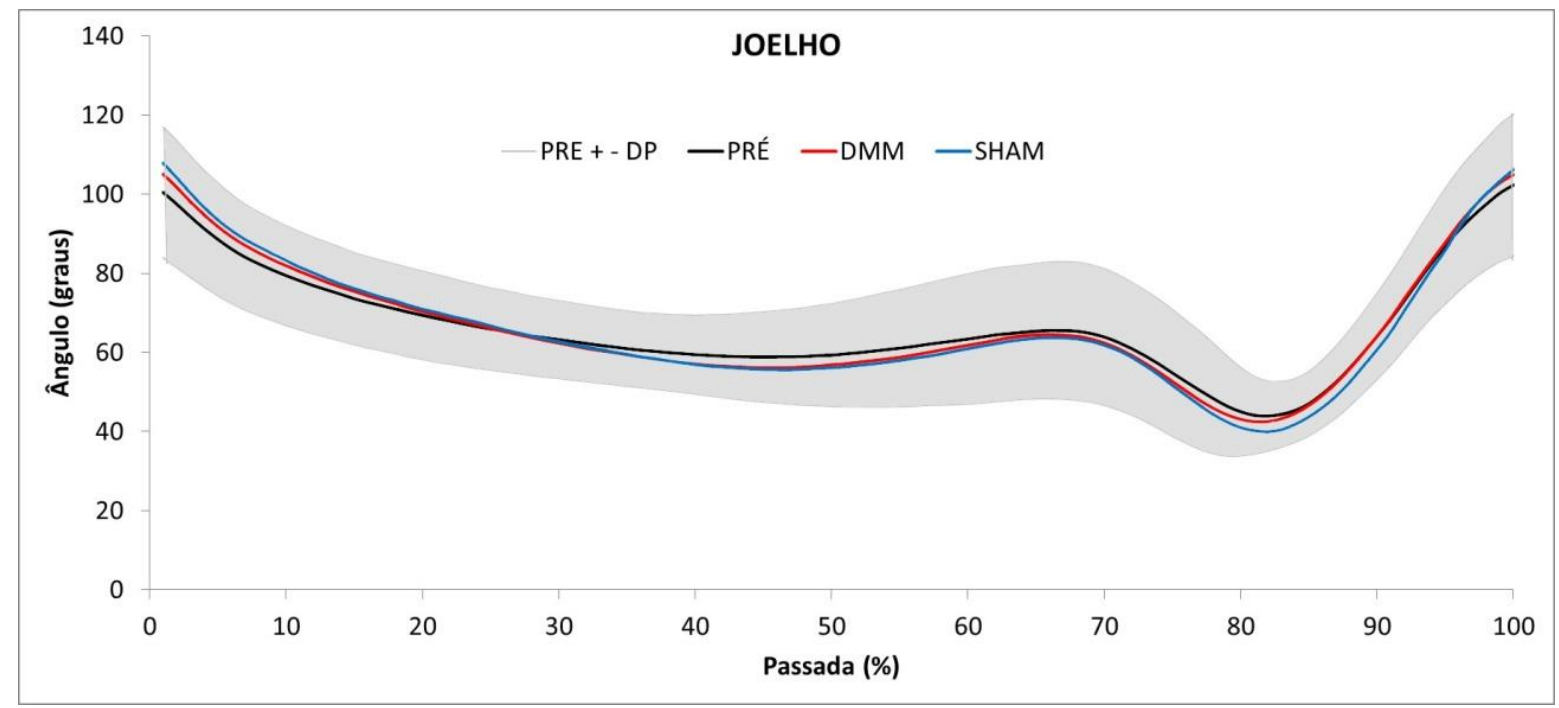

Linha preta: média \pm desvio padrão dos ângulos do joelho, durante a passada de animais sem lesão (PRE) ( $N=22)$; Linha vermelha: média dos ângulos do joelho, durante a passada de animais com desestabilização do menisco medial (DMM) ( $N=17)$; Linha azul: média dos ângulos do joelho, durante a passada de animais com cirurgia placebo, sem rompimento do ligamento menisco-tibial medial (SHAM) ( $\mathrm{N}=7)$.

Figura 45. Curva do padrão normal da marcha (área cinza) para a articulação do joelho

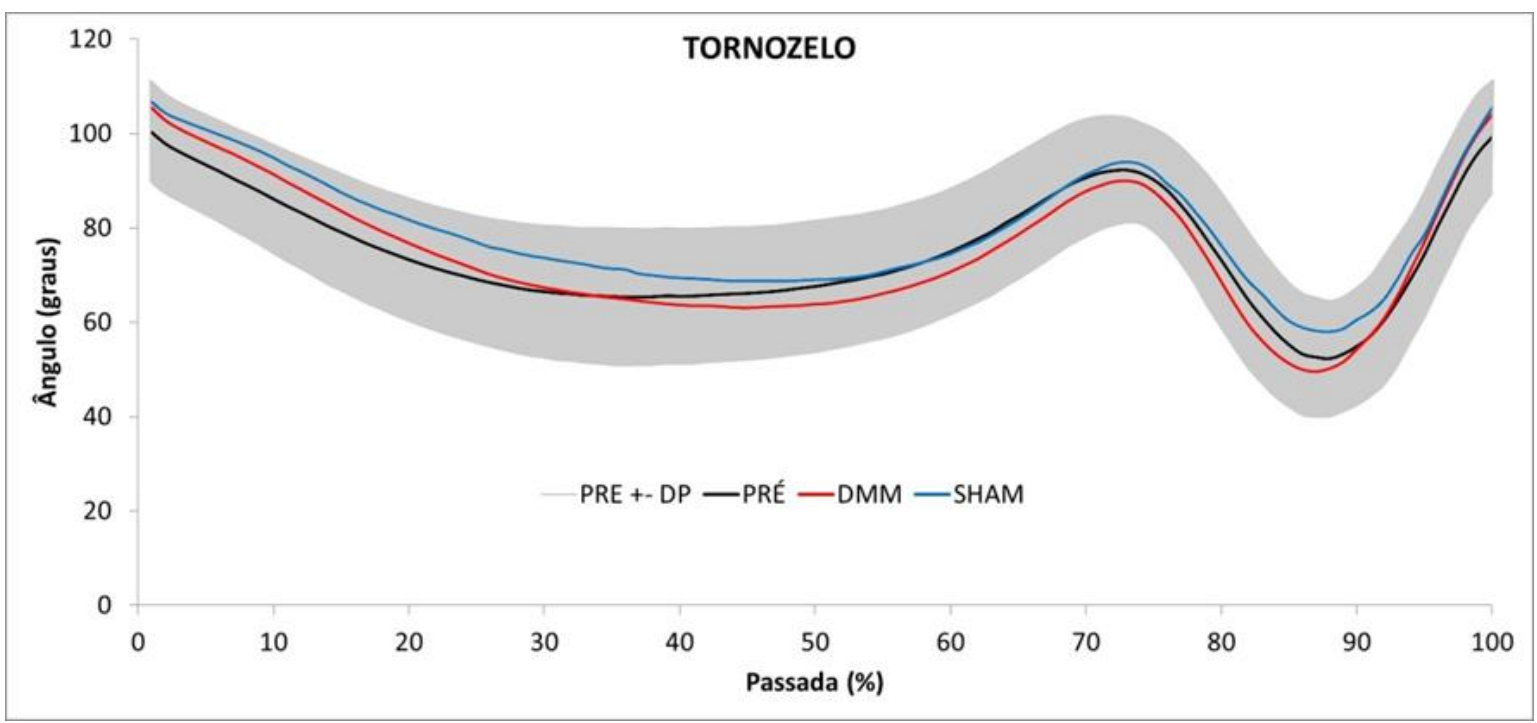

Linha preta: média \pm desvio padrão dos ângulos do tornozelo durante a passada de animais sem lesão (PRE) ( $\mathrm{N}=22)$; Linha vermelha: média dos ângulos do tornozelo durante a passada de animais com desestabilização do menisco medial (DMM) ( $N=17)$; Linha azul: média dos ângulos do tornozelo, durante a passada de animais com cirurgia placebo sem rompimento do ligamento menisco-tibial medial (SHAM) $(\mathrm{N}=7)$.

Figura 46. Curva do padrão normal da marcha (área cinza) para a articulação do tornozelo 


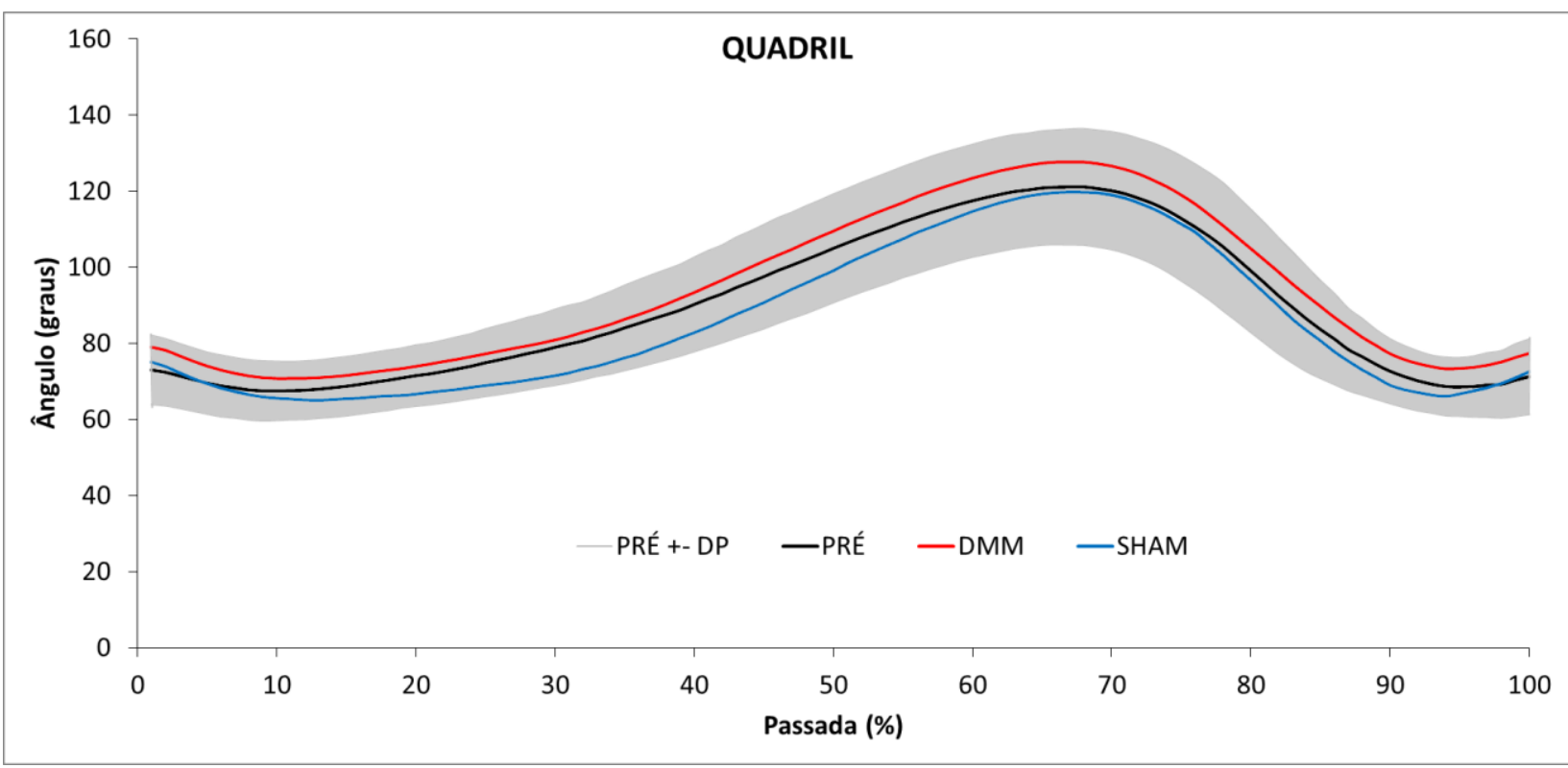

Linha preta: média \pm desvio padrão dos ângulos do quadril, durante a passada de animais sem lesão (PRE) ( $\mathrm{N}=22)$; Linha vermelha: média dos ângulos do quadril, durante a passada de animais com desestabilização do menisco medial (DMM) $(\mathrm{N}=17)$; Linha azul: média dos ângulos do quadril, durante a passada de animais com cirurgia placebo, sem rompimento do ligamento menisco-tibial medial (SHAM) $(\mathrm{N}=7)$.

Figura 47. Curva do padrão normal da marcha (área cinza) para a articulação do quadril

\subsubsection{Baropodometria e análise de performance}

Não observamos diferença entre o padrão de pisada do MIOA (operado) com relação ao MICL (contralateral), nove semanas após a cirurgia DMM (Figura 48).
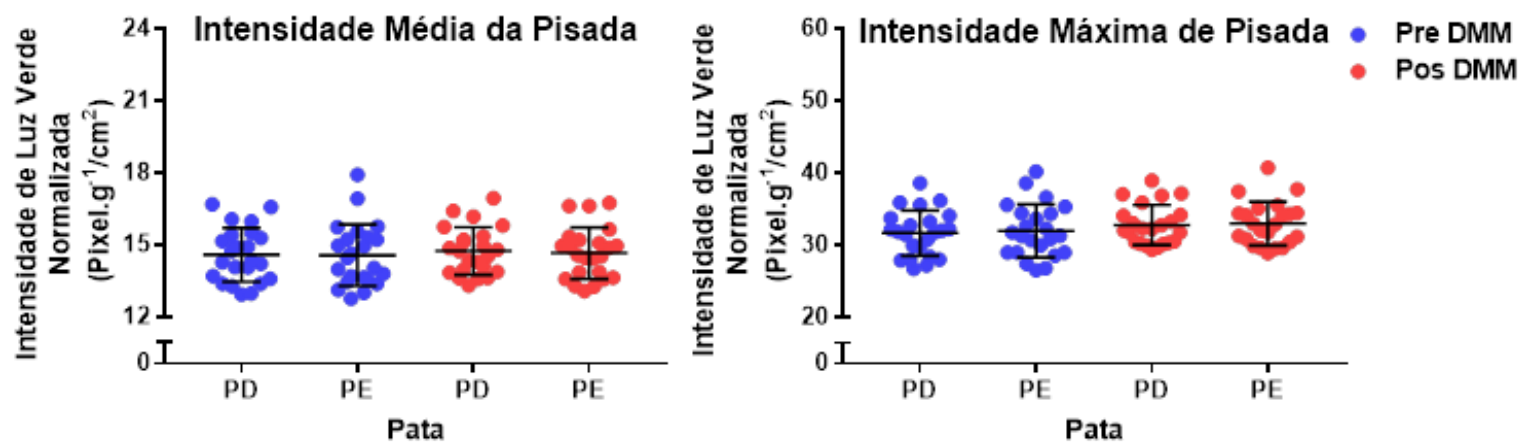

Gráfico com valores de média $(A)$ e máxima (B) da intensidade de luz verde da pegada do animal, normalizada pelo peso corporal e área de contato da pegada. Pontos azuis: avaliação pré-cirurgia de desestabilização do menisco medial (DMM); Pontos vermelhos: nove semanas após cirurgia DMM; N=24. PD: Pata posterior direita; PE: Pata posterior esquerda.

Figura 48. Baropodometria com sistema CatWalk ${ }^{\circledR}$

O tempo de permanência dos animais sobre o rotor no teste incremental Rotarod $^{\circledR}$ foi menor, nas duas coletas Pós-DMM, em comparação com as 
coletas Pré-DMM, significando uma redução de performance. Não há diferença significante entre as coletas Pré-SHAM e Pós-SHAM. Apesar das diferenças intragrupo (Pré-DMM $x$ Pós-DMM) descritas, não há diferença entre os tipos de intervenção cirúrgica (DMM $x$ SHAM), para nenhum dos momentos avaliados (Figura 49A).

Para o teste de Escalada, o tempo de realização da tarefa foi menor nas duas coletas Pós-DMM, comparando-se com as coletas Pré-DMM. Da mesma forma, o tempo de escalada foi menor nas duas coletas Pós-SHAM, em comparação com a coleta C2 Pré-SHAM. Também, aos animais Pré-DMM, houve redução do tempo de escalada entre as coletas C2 e C3 (Figura 49B). Ao contrário do teste Rotarod ${ }^{\circledR}$, a redução do tempo de execução do teste significa melhora da performance.
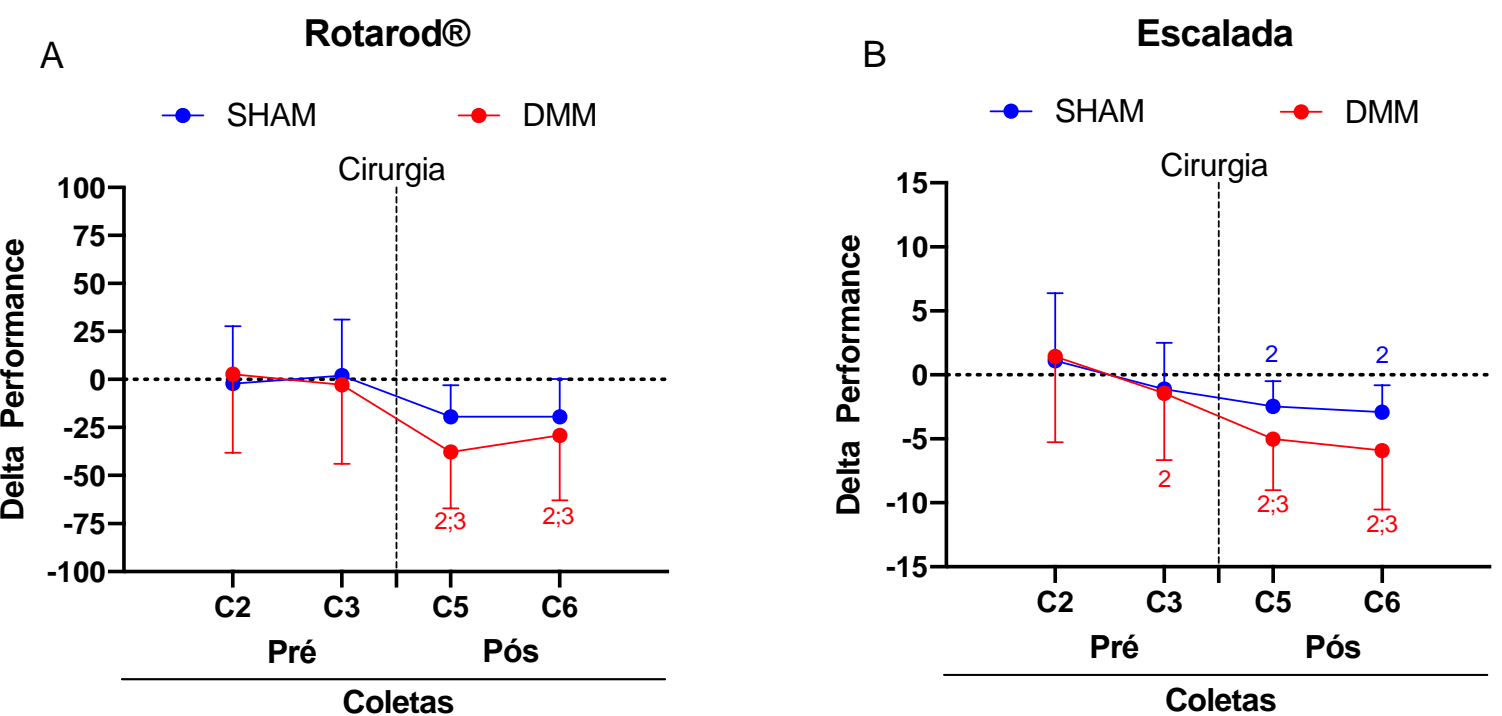

C2-C3: Coletas antes da cirurgia; C5-C6: coletas nove semanas após cirurgia; Dados expressos em função do delta, entre um ponto de coleta e a média delas Pré (2-3), para seu respectivo grupo. (A) Tempo de permanência do animal no teste Rotarod ${ }^{\circledR}$. (B) Tempo para escalar a escada. DMM: cirurgia de desestabilização do menisco medial ( $\mathrm{N}=24)$; SHAM: cirurgia sem desestabilização do menisco medial $(\mathrm{N}=16)$. Números vermelhos: número da coleta em que $p \leq 0,05$ para comparações entre medidas repetidas do grupo DMM; Números azuis: número da coleta em que $\mathrm{p} \leq 0,05$ para comparações entre medidas repetidas do grupo SHAM.

Figura 49. Avaliação de performance motora antes (Pré) e nove semanas após (Pós) intervenção cirúrgica

\subsection{Avaliação histopatológica e radiográfica}

Observou-se, qualitativamente, nas radiografias do joelho, os animais que passaram por cirurgia DMM apresentando calcificação e extrusão do menisco medial, apenas no joelho operado, após nove semanas (Figura 50). 
As análises radiográficas dos tempos de eutanásia pós-tratamento (quatro ou 12 semanas) apresentam, para todos os grupos DMM, os mesmos sinais radiográficos descritos acima. Já para os, com cirurgia SHAM, esses sinais radiológicos não se encontram presentes, com a mesma intensidade (Figura 51). Apesar da avaliação qualitativa, não encontramos uma forma eficaz de avaliação quantitativa destes sinais radiográficos, que possibilite comparações entre grupos e tempo de eutanásia.

Após avaliação do grau de acometimento da CA pelo modelo de OA, identificamos que as intervenções cirúrgicas SHAM realizaram-se com sucesso, pois não encontramos sinal de $\mathrm{OA}$ em nenhum animal. Por tal motivo, apesar de representados nos gráficos, não se incluíram na análise estatística (Figura 54).

Quando observamos a coloração de Safranina-O das imagens representativas da média dos grupos, não encontramos diferença estatística significante entre nenhuma das comparações DMM+PLACEBO $x$ DMM+CTM (Figura 52, 53 e 54), e em nenhuma das escalas utilizadas para quantificar o grau de OA. Da mesma forma da lesão da cartilagem, não foram identificados sinais de alteração da membrana sinovial, em nenhum dos grupos analisados (Figura 56).

Os dados de imuno-histoquímica sugerem haver um aumento na expressão de colágeno tipo 2, nos perímetros da lesão da cartilagem (Figura 55). Porém, não houve possibilidade de diferenciar, qualitativamente, se o transplante celular alterou a resposta do Colágeno tipo 1 ou tipo 2, após quatro semanas do transplante. Também, não foi possível realizar a imuno-histoquímica dos grupos de 12 semanas, após transplante. Ressaltamos a dificuldade em realizar as análises de imuno-histoquímica, pois os cortes histológicos, provavelmente devido ao tamanho e ao processo de descalcificação, apresentaram pouca adesão à lâmina silanizada, durante o tratamento de recuperação antigênica. Mesmo após adaptações das etapas da imuno-histoquímica, alguns cortes não puderam ser analisados, e tal fato inviabilizou, em alguns casos, utilizar o corte histológico, imediatamente sequencial ao corte, utilizado na coloração de Safranina-O, como representativo da média do grupo. 


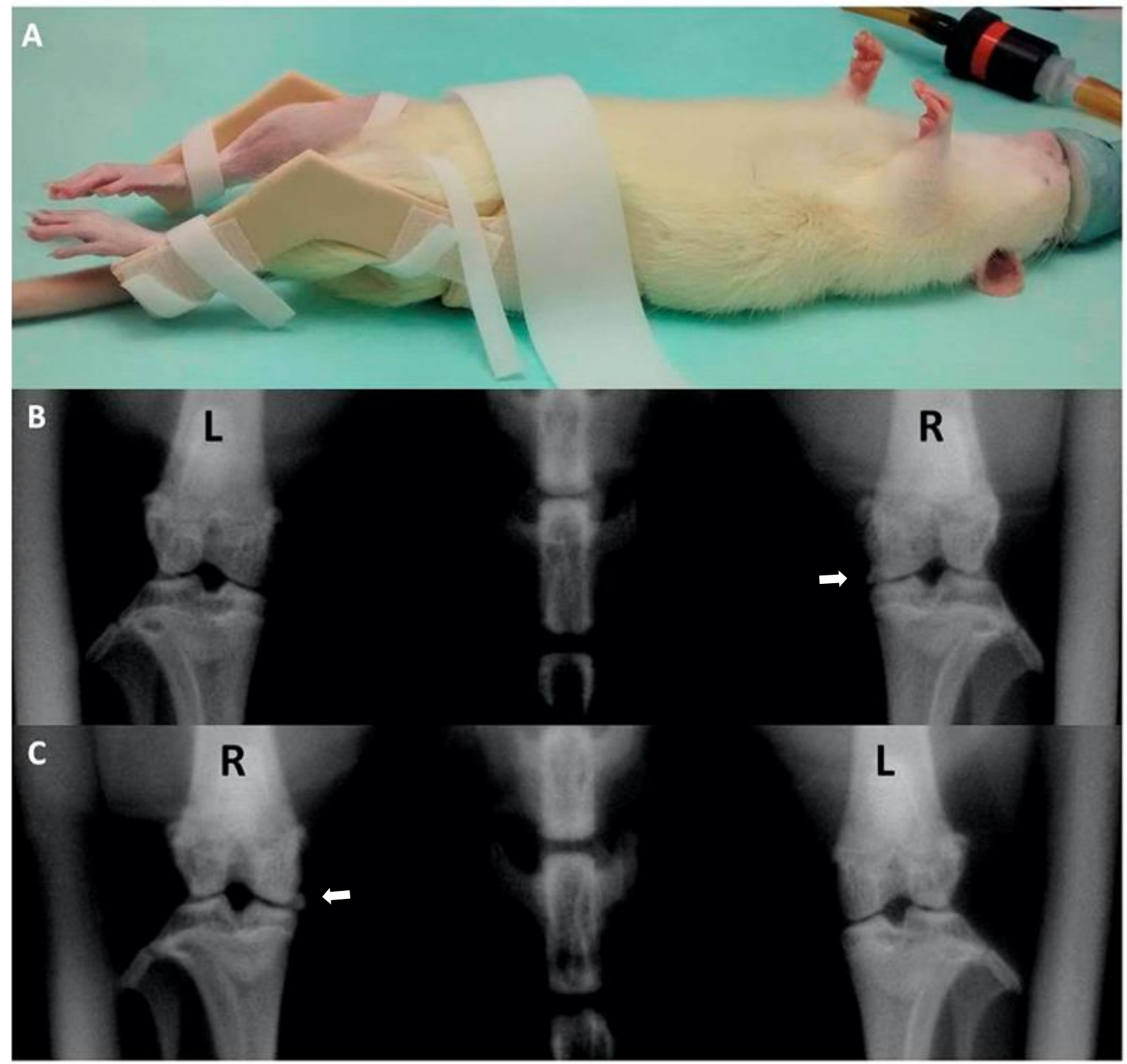

(A) Órtese de termoplástico em flexão de $\approx 120^{\circ}$ do joelho; (B e C) Radiografia em visão posterior e anterior do joelho, respectivamente. Seta branca: exemplo indicativo de calcificação do menisco. R: joelho direito (right) operado; (L): joelho esquerdo (left) não operado; $\mathrm{N}=6$.

Fonte: Adaptado de Dias de Oliveira FB, Souza JG, Furiama O, Ferretti M, Antoniolli E. Imaging and functional assessment of medial meniscos surgical destabilization animal model for osteoarthritis. Osteoarthritis Cartilage. 2018; 26(Suppl 1):S471-2. ${ }^{(106)}$

Figura 50. Radiografia das articulações do joelho, após nove semanas da cirurgia de desestabilização do menisco medial 


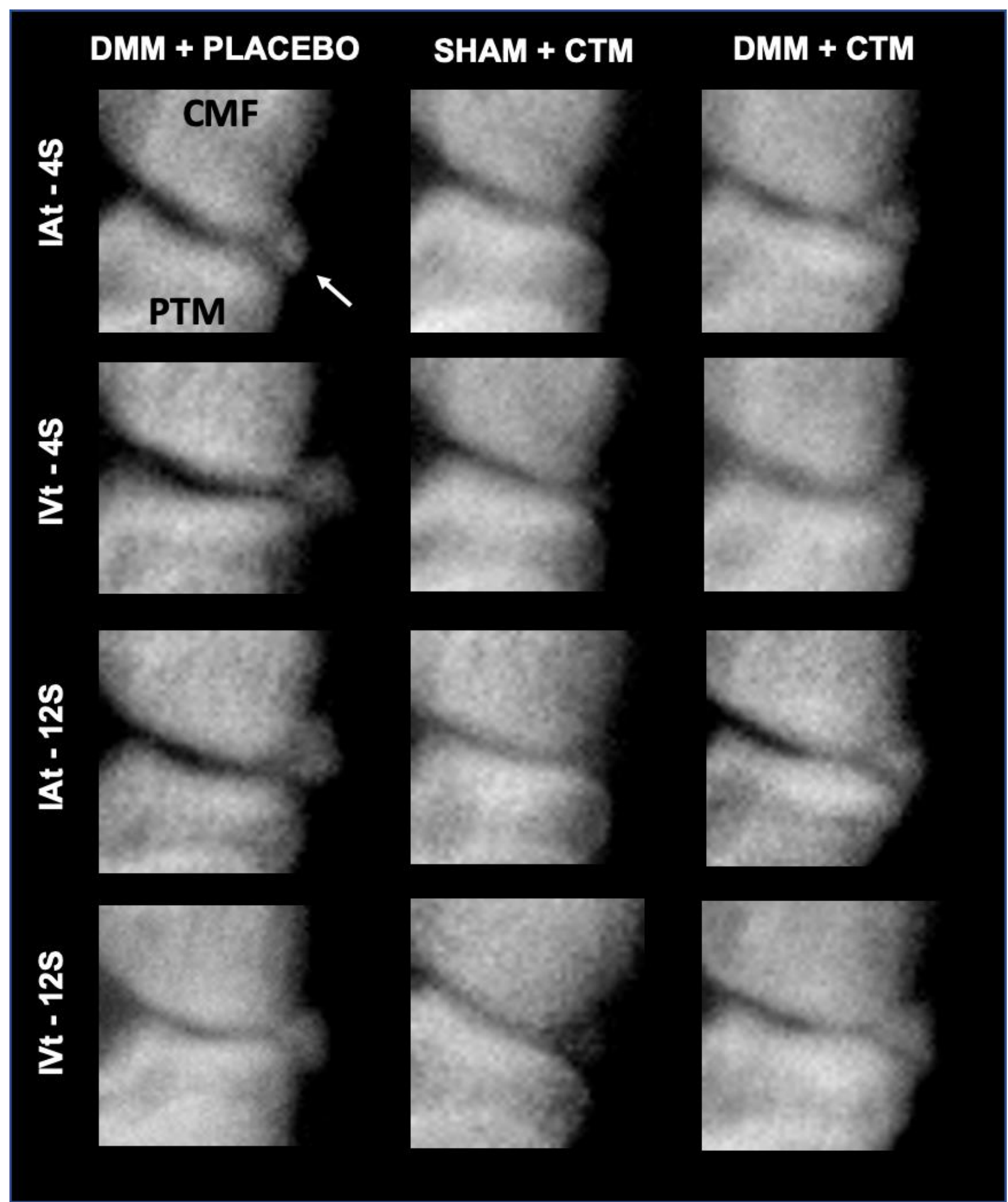

Platô tibial medial (PTM) e côndilo medial do fêmur (CMF), após quatro (4S) e 12 semanas (12S) do transplante celular intra-articular (IAt) ou intravenoso (IVt). Seta branca: exemplo indicativo de calcificação do menisco. DMM: desestabilização do menisco medial; PLACEBO: cloreto de sódio 0.9\%; SHAM: cirurgias em desestabilização do menisco medial; CTM: célula-tronco mesenquimal.

Figura 51. Radiografia do joelho, após tratamentos 
Média
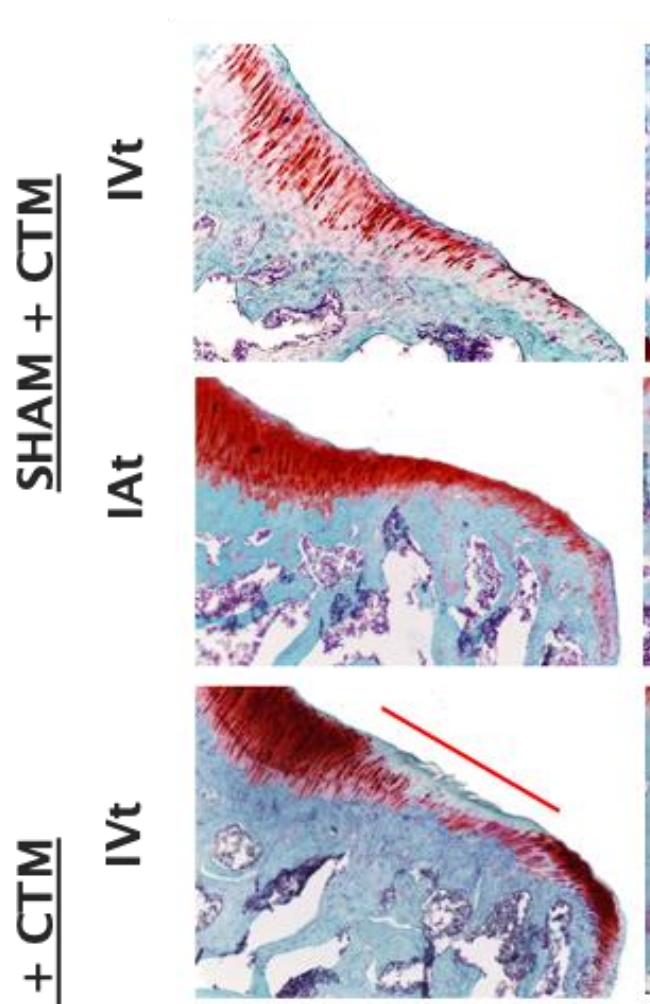

$\sum_{0}$

|

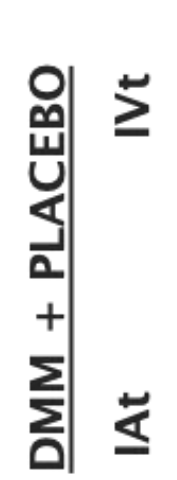

$\check{s}$

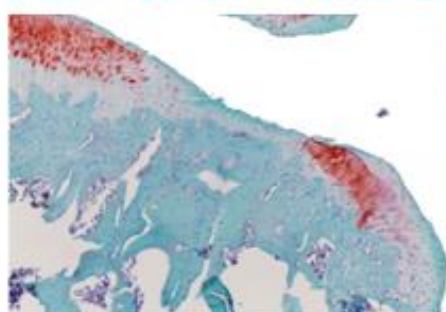

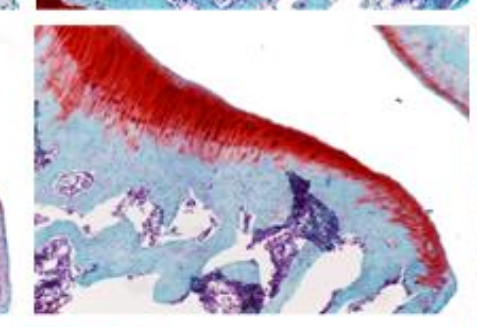
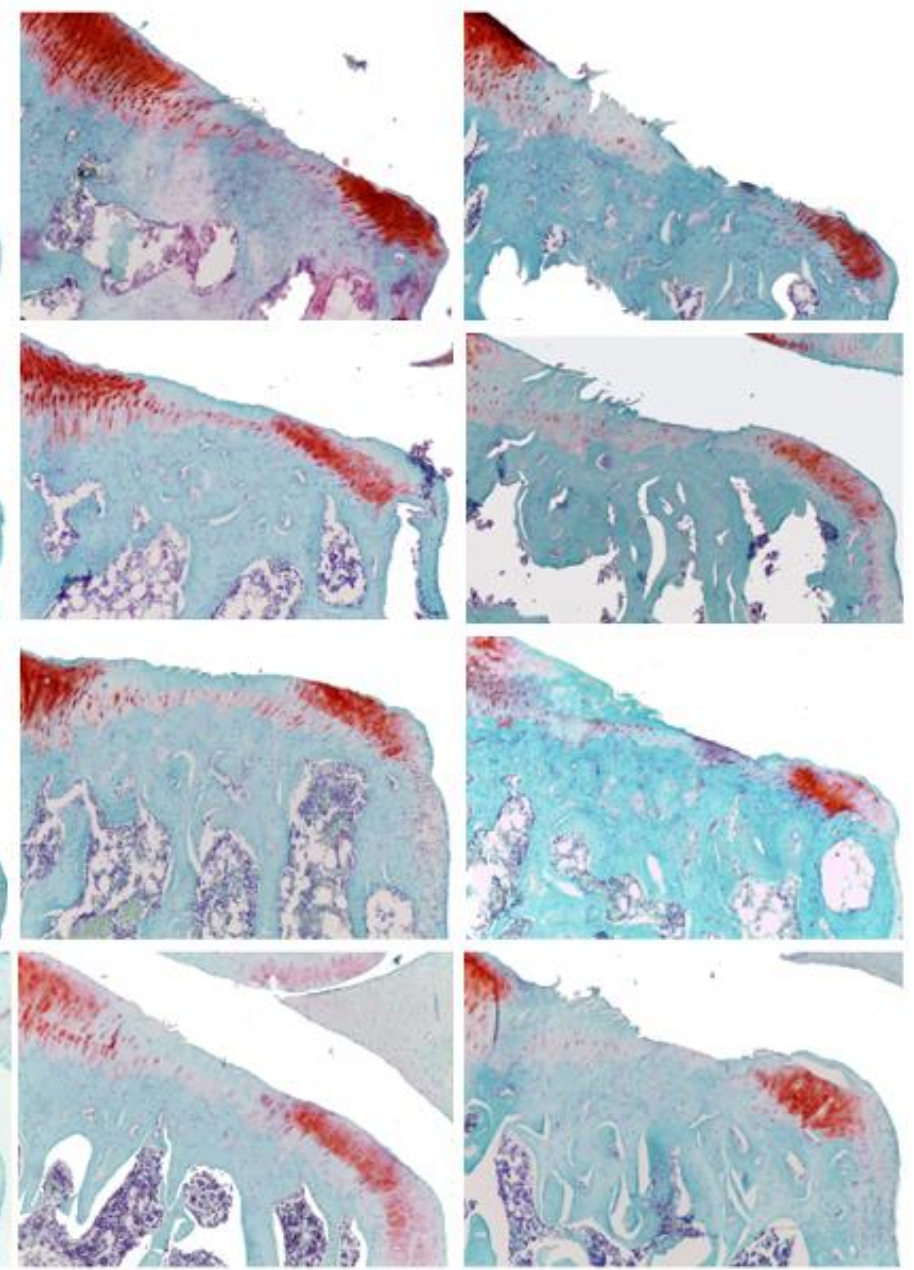

Imagens representativas da média, mínimo e máximo do valor de extensão da lesão $(\mu \mathrm{m})$ em cada grupo. Linha vermelha: Exemplo da mensuração da extensão da lesão. DMM: desestabilização do menisco medial; PLACEBO: cloreto de sódio 0.9\%; SHAM: cirurgias em desestabilização do menisco medial; CTM: célula-tronco mesenquimal; PTM: Platô tibial medial; 4S: quatro semanas; IAt: transplante celular intra-articular; IVt: transplante celular intravenoso.

Figura 52. Coloração histológica da cartilagem articular por Safranina-O, quatro semanas, após tratamento celular 


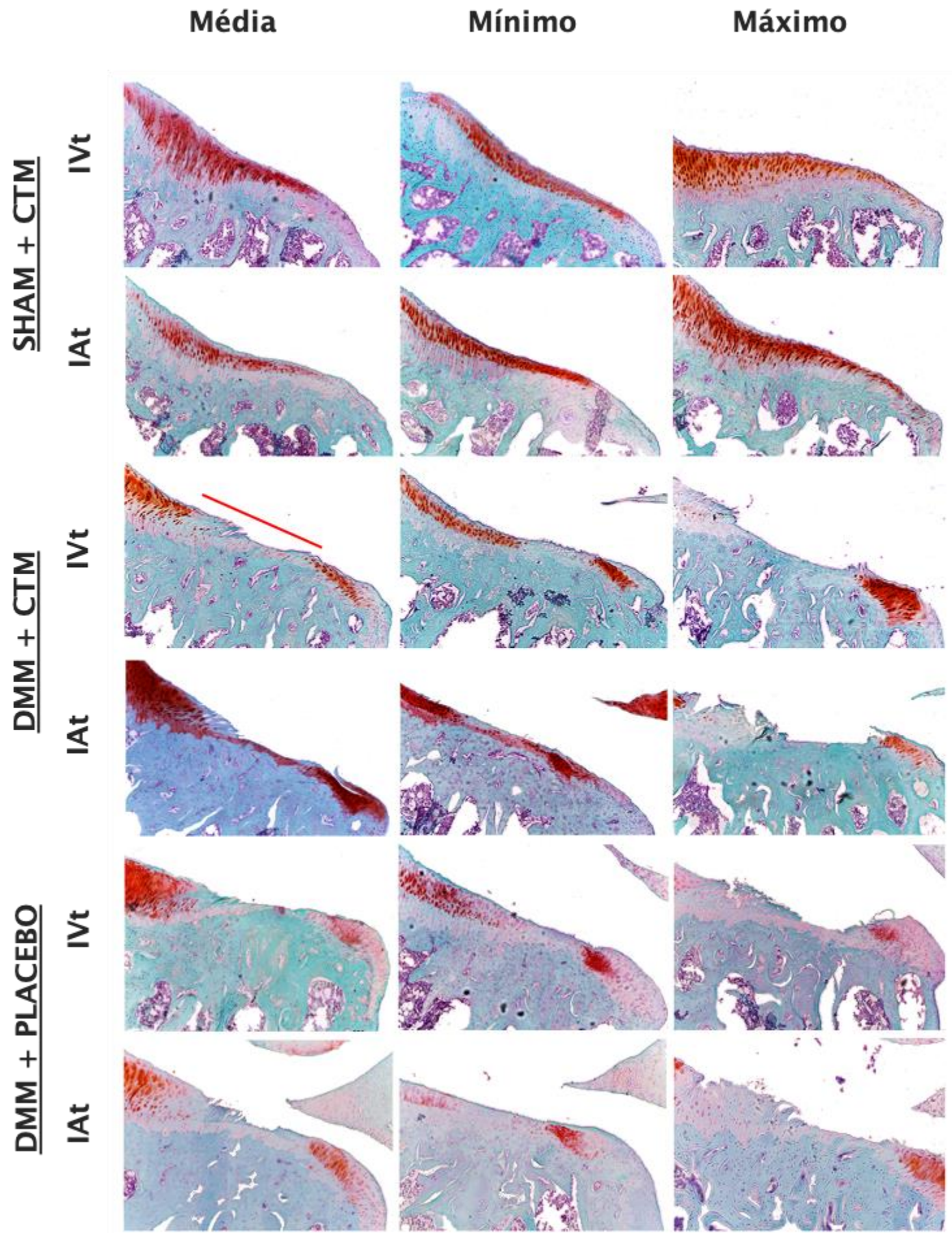

Imagens representativas da média, mínimo e máximo do valor de extensão da lesão $(\mu \mathrm{m})$ em cada grupo. Linha vermelha: Exemplo da mensuração da extensão da lesão. DMM: desestabilização do menisco medial; PLACEBO: cloreto de sódio $0.9 \%$; SHAM: cirurgia sem desestabilização do menisco medial; CTM: célula-tronco mesenquimal; PTM: Platô tibial medial; 12S - 12 semanas; IAt: transplante celular intra-articular; IVt: transplante celular intravenoso.

Figura 53.Coloração histológica da cartilagem articular por Safranina-O, 12 semanas após tratamento celular 
Escala OARSI

A

$\triangle \nabla \mathrm{SHAM}+\mathrm{CTM} \Delta \nabla \mathrm{DMM}+\mathrm{PLACEBO} \Delta \nabla \mathrm{DMM}+\mathrm{CTM}$

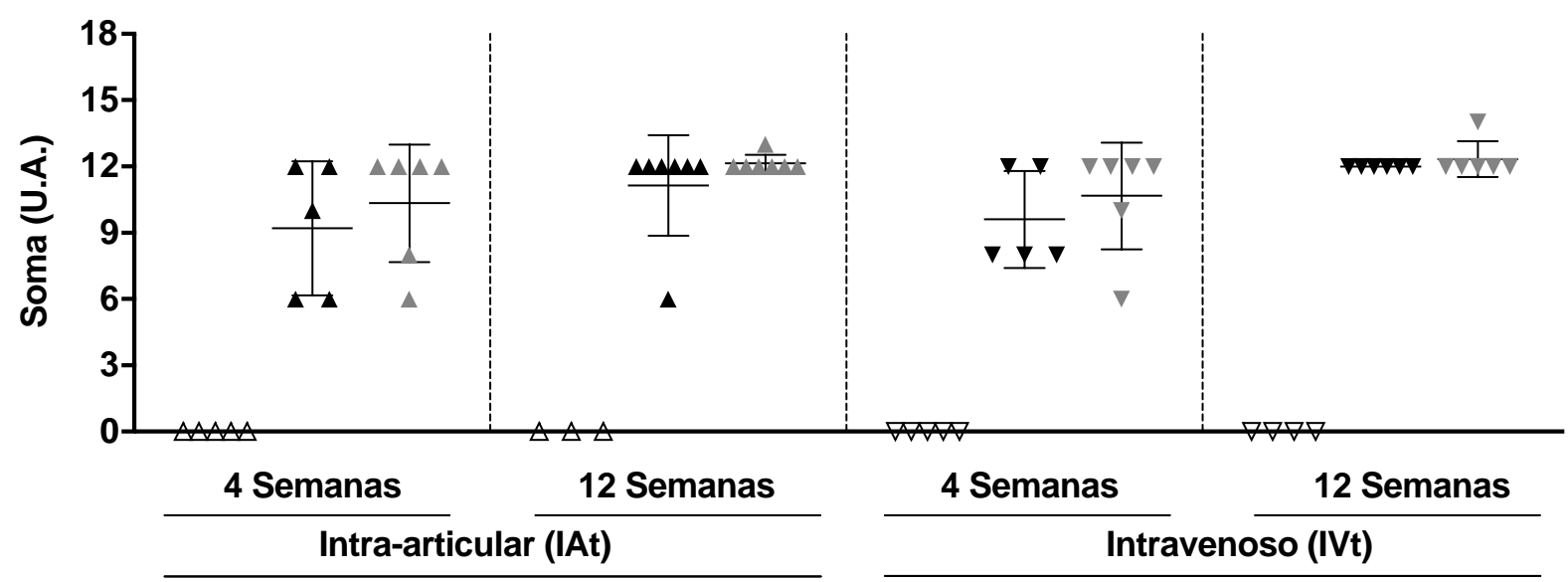

Extensão da Lesão

B $\triangle \nabla \mathrm{SHAM}+\mathrm{CTM} \Delta \mathbf{\nabla} \mathrm{DMM}+\mathrm{PLACEBO} \Delta \mathrm{V} \mathrm{DMM}+\mathrm{CTM}$

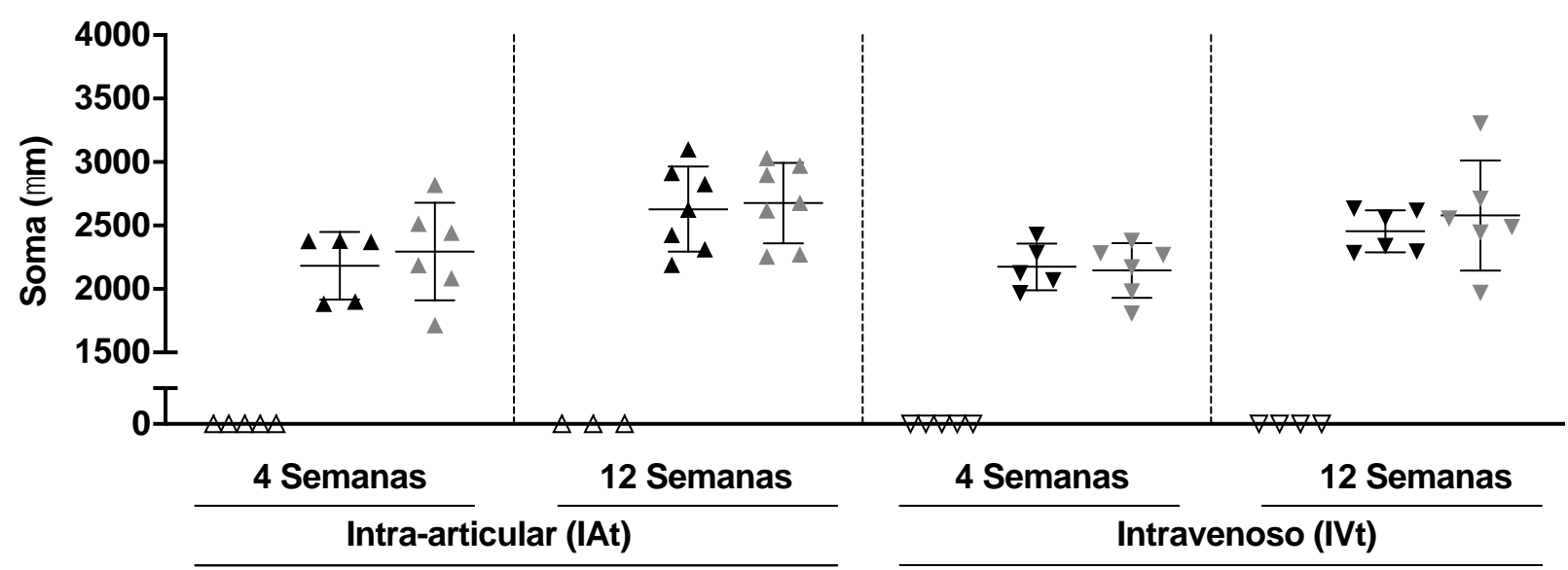

Soma das três lâminas com maiores valores de extensão de lesão. Dados obtidos, após quatro (4S) e12 semanas (12S) do transplante celular intra-articular (IAt) ou intravenoso (IVt). (A) Escala OARSI; (B) Tamanho da extensão da lesão. DMM: desestabilização do menisco medial; PLACEBO: cloreto de sódio $0.9 \%$; SHAM: cirurgia sem desestabilização do menisco medial; CTM: célula-tronco mesenquimal; U.A.: unidade arbitrária.

Figura 54. Quantificação histológica do grau de osteoartrose no platô tibial medial 
Colágeno I

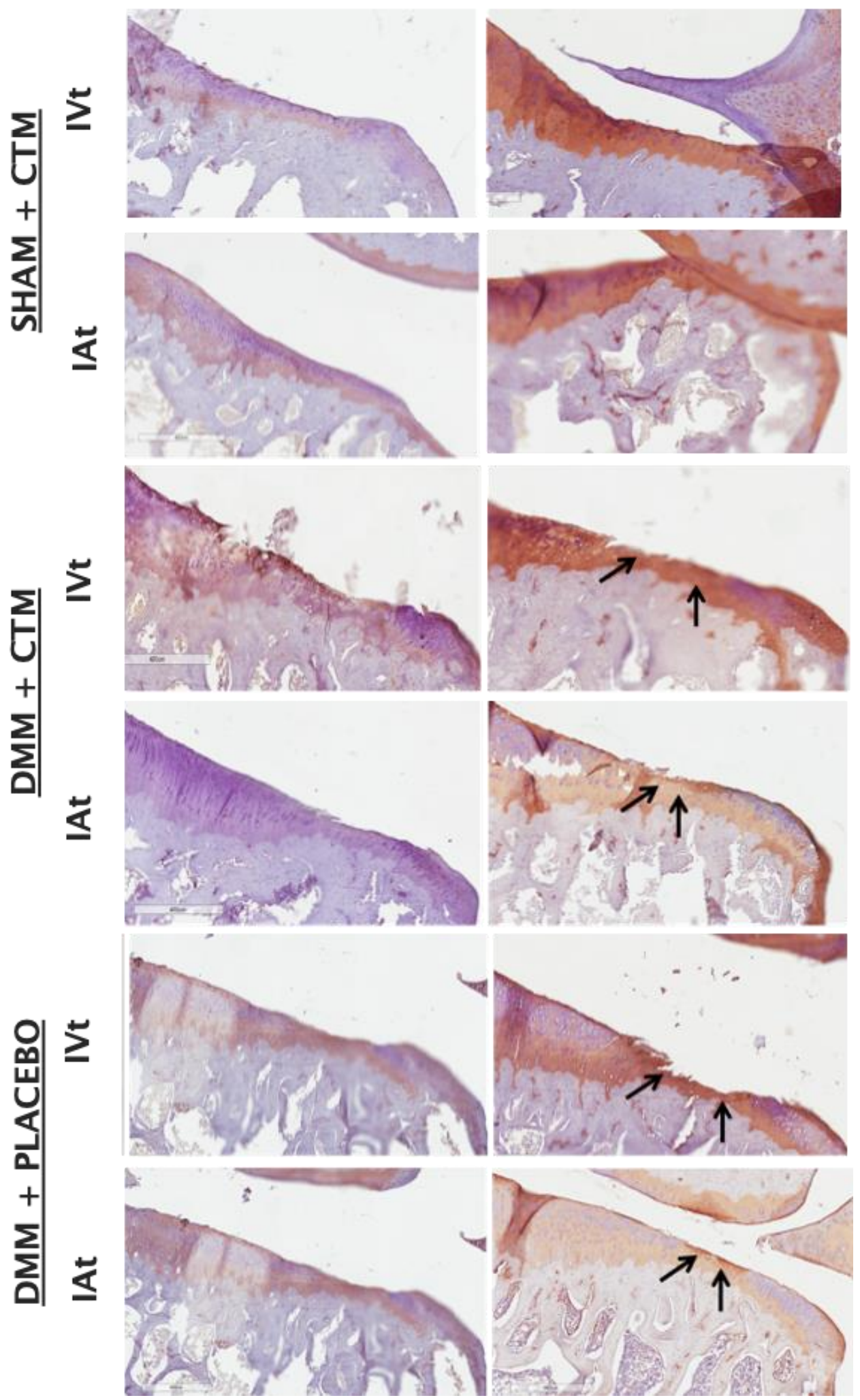

Seta preta: Marcação de Colágeno II ao redor da lesão. DMM: desestabilização do menisco medial; PLACEBO: cloreto de sódio 0.9\%; SHAM: cirurgia sem desestabilização do menisco medial; CTM: célula-tronco mesenquimal; PTM: platô tibial medial; IAt: transplante celular intra-articular; IVt: transplante celular intravenoso.

Figura 55. Imuno-histoquímicada cartilagem para Colágeno I e II quatro semanas após tratamento celular 

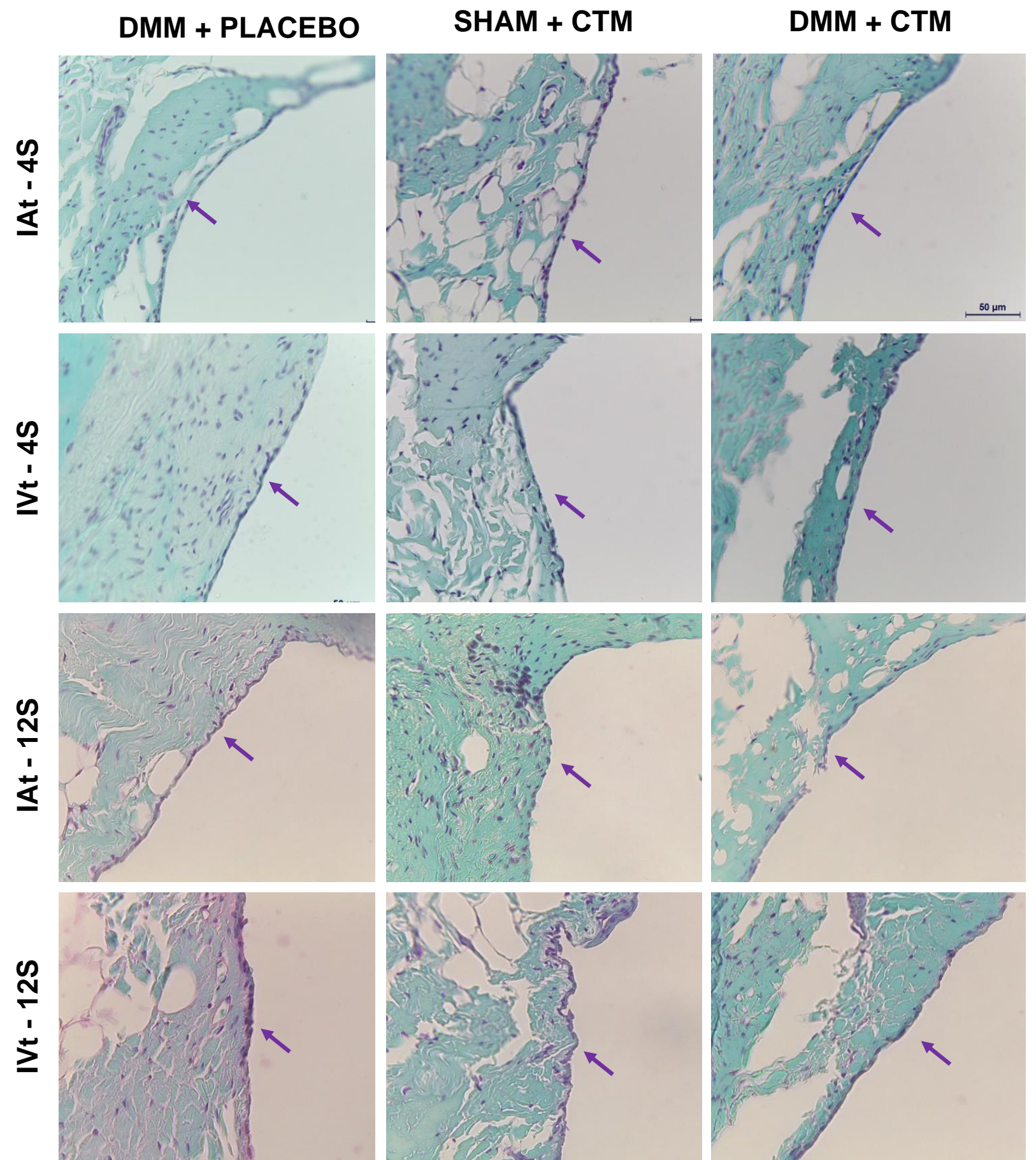

Seta roxa: coloração nuclear com Hematoxilina de células da linha sinovial. DMM: desestabilização do menisco medial; PLACEBO: cloreto de sódio 0.9\%; SHAM: cirurgia sem desestabilização do menisco medial; CTM: célula-tronco mesenquimal; IAt: transplante celular intra-articular; IVt: transplante celular intravenoso. 4S: quatro semanas; $12 \mathrm{~S}$ : 12 semanas.

Figura 56. Análise da hiperplasia celular da membrana sinovial, após quatro e 12 semanas do transplante celular 


\subsection{Análise do perfil inflamatório}

\subsubsection{Sangue/soromodelo animal de desestabilização do menisco medial}

Das citocinas analisadas, observou-se sinal das moléculas MIP-1a, IL-1 $\beta$, IL-10, IL-18, MCP-1 e RANTES, na maioria das amostras. As citocinas IL-4, IL-6, IL-13 e TNF- $\alpha$ não apresentaram consistência no sinal, que permitisse análise estatística para todos os grupos.

Foi possível identificar diferença significante do nível sérico de citocina, antes e após o desenvolvimento de OA por DMM, apenas para MIP-1a (Figura $57)$.

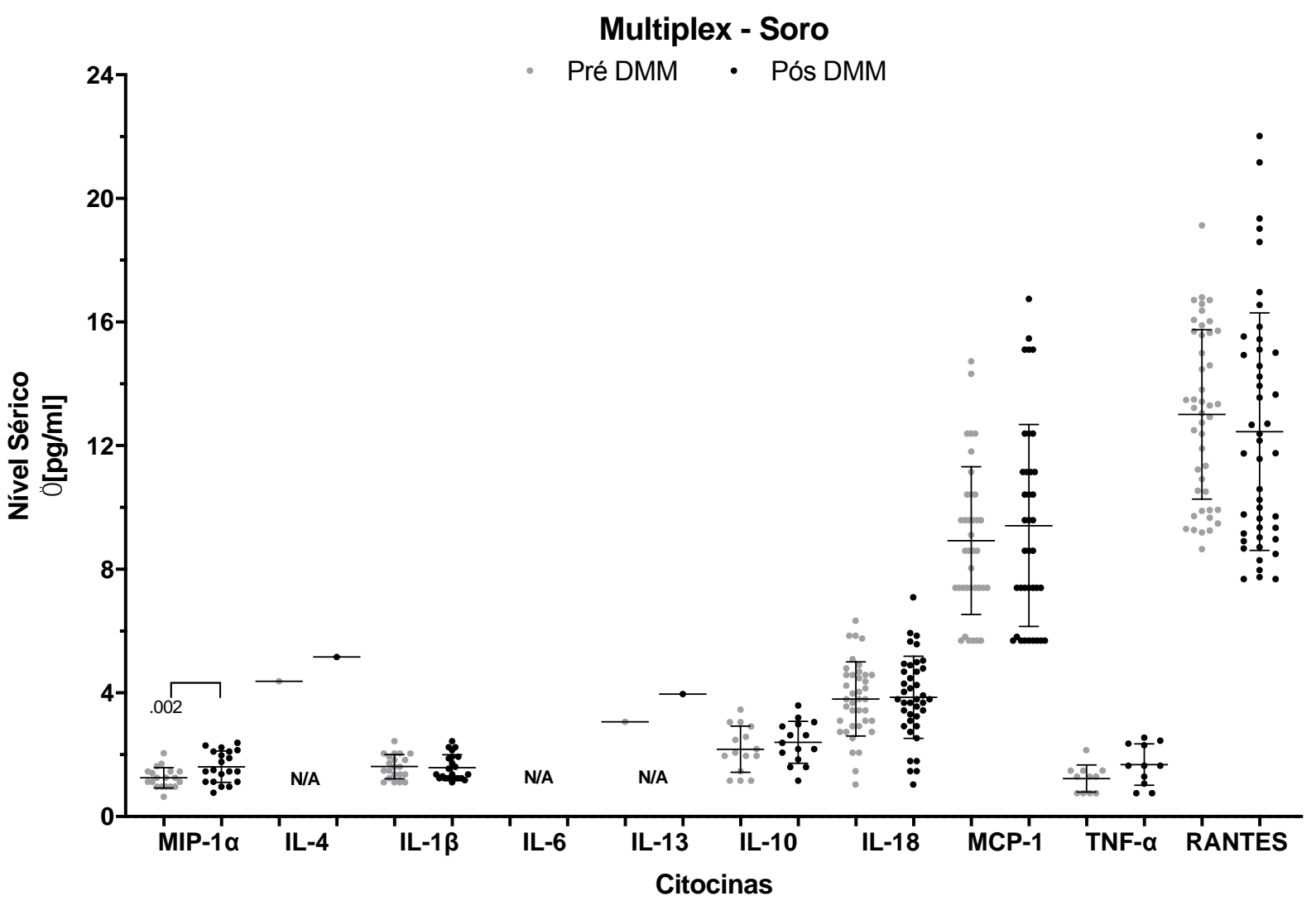

Análise anterior (Pré) e posterior (Pós), a nove semanas da cirurgia de desestabilização do menisco medial (DMM). Colchete preto: $\mathrm{p} \leq 0,05$; N/A: Teste estatístico não aplicável $(\mathrm{N}<3)$; Animais avaliados: $\mathrm{N}=45$.

Figura 57. Comparação pareada de níveis séricos de citocinas 


\subsubsection{Soro/sangue agudo}

Alterações dos níveis séricos, logo após o IAt ou IVt, foram encontradas para MIP-1a, IL-10, IL-18, MCP-1 e RANTES (Figura 58).

Ao G-IAt, em uma semana (1S), há uma redução de IL-18 e MCP-1, comparando-se com o ponto $24 \mathrm{H}$. A referida redução em $1 \mathrm{~S}$, também está presente para MCP-1 e RANTES, em comparação com o ponto 2H. Ao G-IVt. Há um aumento de MIP-1a e IL-10, em 2H, comparados aos valores basais (Pós-DMM). Os níveis de MIP-1a reduziram, em $24 \mathrm{H}$, e se mantiveram baixos e $1 \mathrm{~S}$. Também, em 1S, há uma redução de IL-10 e IL-18, em relação a 24H. Não se fez possível detectar IL-1ß, em $24 \mathrm{H}$, em animais suficientes à realização de comparações.

Para o G-IAt, o nível sérico de MCP-1, em 24H, mostrou-se maior do que para o G-IVt. Já os valores das citocinas IL-10 e MIP-1a, em $2 \mathrm{H}$, foram maiores ao G-IVt. 
A

IL-1

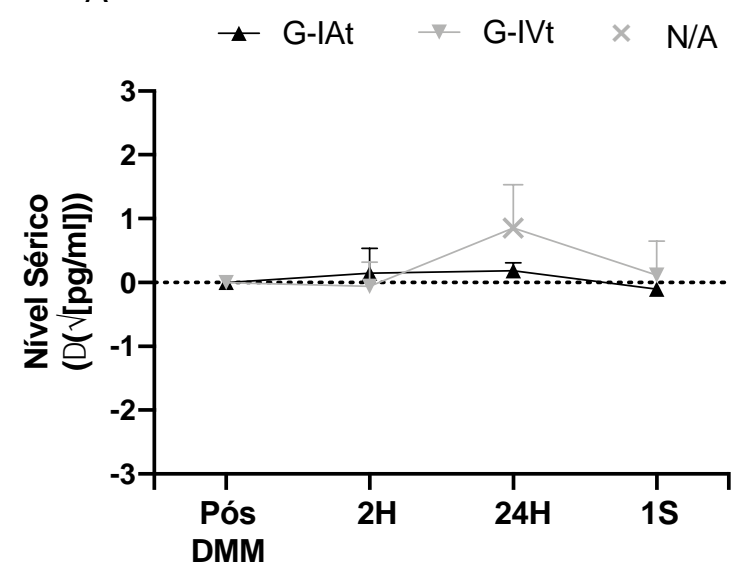

B

IL-18
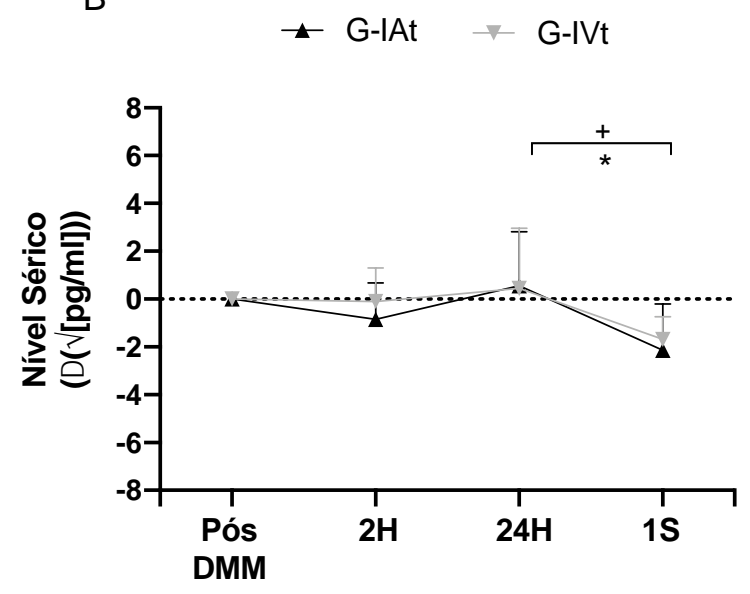

C

MCP-1

$\neq$ G-IAt $\rightarrow$ G-IVt

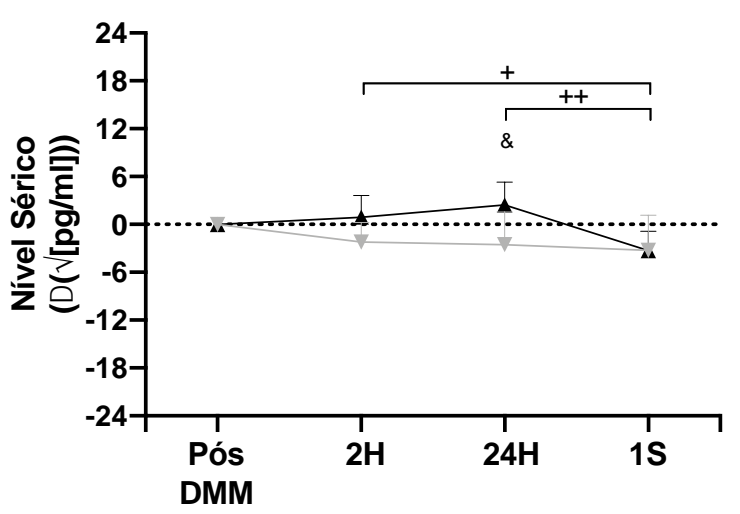

D

MIP-1

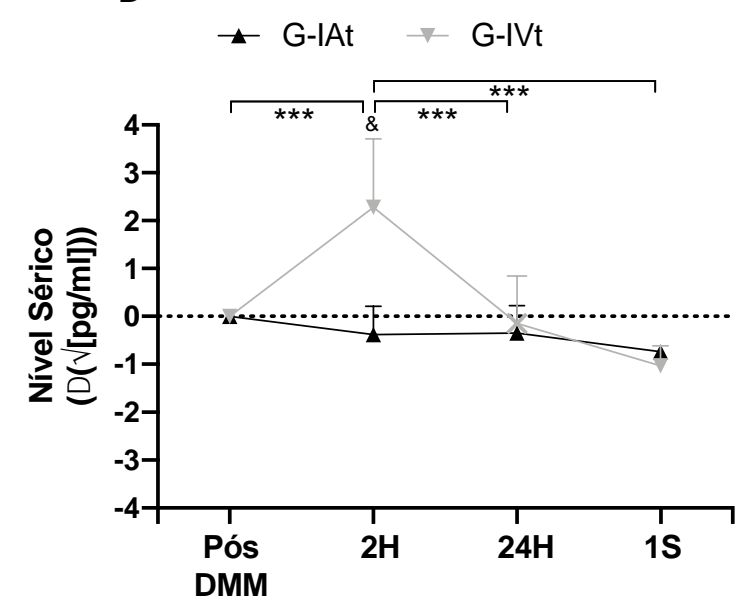

E

IL-10

$\neq$ G-IAt $\rightarrow$ G-IVt

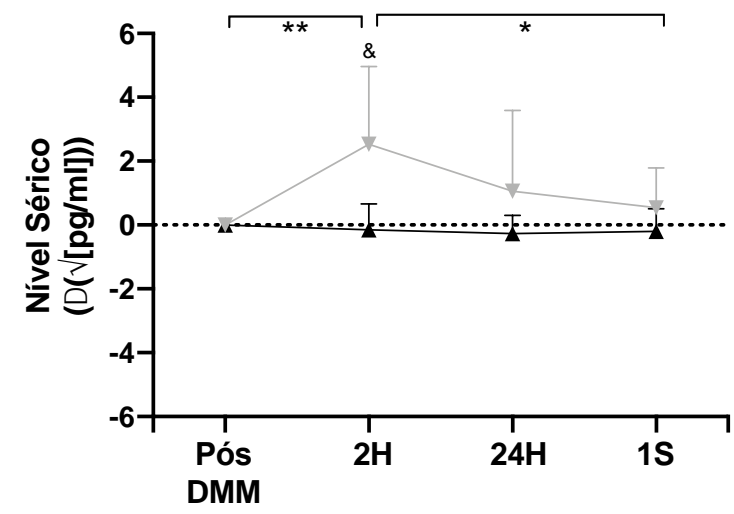

F

RANTES

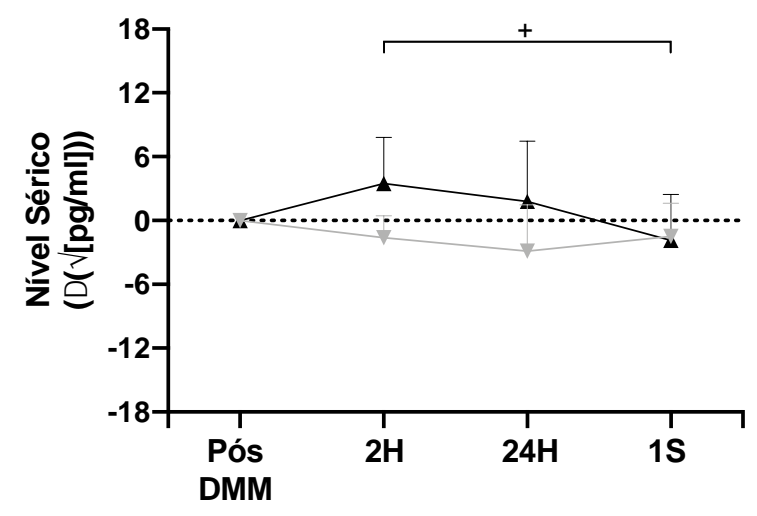

Comparação entre valores de nove semanas, após a cirurgia de desestabilização do menisco medial (Pós-DMM), duas horas (2H), 24 horas $(24 \mathrm{H})$ e uma semana (1S), após transplante de células por via intravenosa (IVt) ou intra-articular (IAt). Linha pontilhada representa a média, dos valores de referência Pós-DMM, pelo qual foi realizado o delta entre amostras. G-IAt: grupo intra-articular; G-IVt: grupo intravenoso; Colchete preto: $p \leq 0,05$. " $\&$ " diferença entre grupos (G-IAtx G-IVt); "+" diferença entre tempos G-IAt; "*” diferença entre tempos G-IVt; N/A: Teste estatístico não aplicável $(\mathrm{N}<3)$; Animais avaliados: $\mathrm{N}=6$ por grupo.

Figura 58. Comparação dos níveis séricos de citocinas ao do estudo agudo 


\subsubsection{Sangue/soro longitudinal}

Separaram-se as citocinas em duas figuras: (Figura 59 - IL-1 $1 \beta$, IL-18 e MCP-1 e Figura 60 - MIP-1 $\alpha$, IL-10 e RANTES), de acordo com o resultado observado no estudo agudo, referente a similaridade da curva de citocinas, em $24 \mathrm{H}$, (Figura 58 A, B e C) e 2H (Figura 58 D, E e F). As amostras válidas de todos os animais testados incluíram-se na mesma análise. Por esse motivo, alguns grupos apresentam $\mathrm{N}$ amostral diferente.

Ao comparar o tratamento celular e tratamento placebo (Figuras $59 \mathrm{e}$ 60), observou-se que, quando realizados via IA, o grupo DMM+CTM-IAt apresentou menor concentração de IL-18, MCP-1, MIP-1a e RANTES, uma semana após o transplante, comparando-se com o grupo DMM+PLACEBO-IAt. O grupo SHAM+CTMIAt apresentou menor concentração de IL-1 $\beta$, MCP-1, MIP-1 $\alpha$ e RANTES, após uma semana; IL-1 $\beta$ e RANTES, após quatro semanas e RANTES, após 12 semanas do transplante, em comparação com o grupo DMM+PLACEBO-IAt. Quando os transplantes se realizaram, por via intravenosa, observou-se que o grupo DMM+CTMIVt apresentou menor concentração de RANTES, em quatro semanas e IL-10 e RANTES, após 12 semanas do transplante, em comparação com o grupo DMM+PLACEBO-IVt. O grupo SHAM+CTM-IVt mostrou menor concentração de MCP1, em quatro semanas e maior de IL-10, uma semana após o transplante, em comparação com o grupo DMM+PLACEBO-IVt.

Colocando o tipo de cirurgia em comparação (Figuras 59 e 60), com grupos que receberam o tratamento celular IA, observa-se que o SHAM+CTM-IAt demonstrou menor concentração de IL-1 $\beta$, em uma semana, e RANTES, em quatro e doze semanas, após transplante, em comparação com o DMM+CTM-IAt. Aos grupos receptores do transplante intravenoso, observa-se que o SHAM+CTM-IVt apresentou maior concentração de IL-10, uma semana após transplante, em comparação com o DMM+CTM-IVt.

No que se refere aos grupos DMM+CTM (Figura 61), identificou-se diferença significante, entre vias de transplante em $1 S$ para IL-1 $\beta$. 
A

IL-1

A

$\mathrm{DMM}+\mathrm{PLACEBO} \quad \triangle \nabla \mathrm{SHAM}+\mathrm{CTM}$

$\mathrm{DMM}+\mathrm{CTM}$

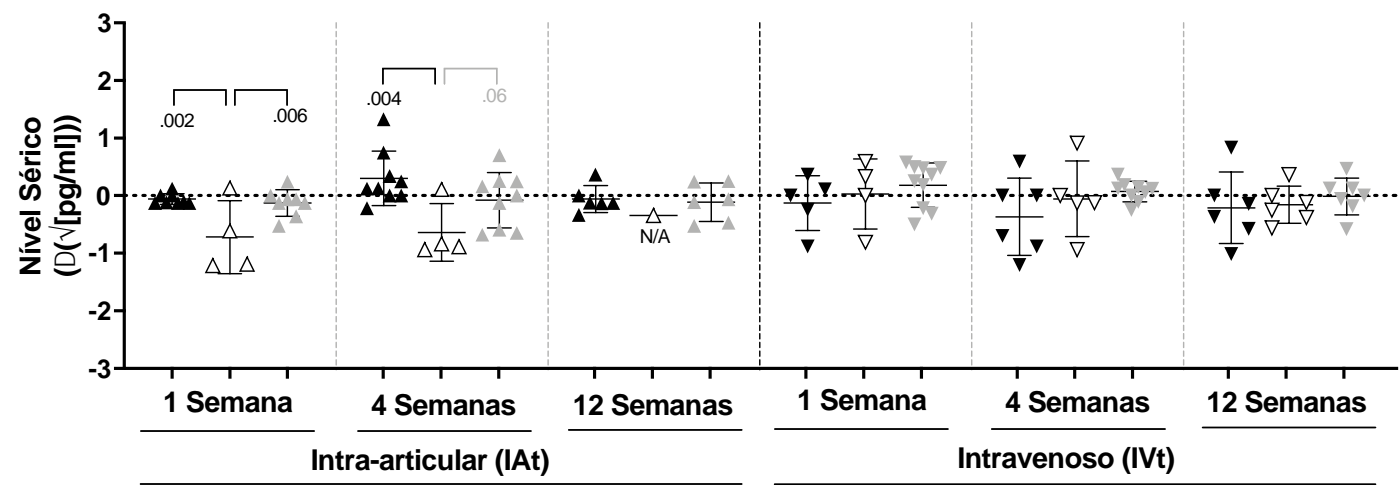

B

IL-18

$\mathrm{DMM}+\mathrm{PLACEBO} \quad \triangle \nabla \mathrm{SHAM}+\mathrm{CTM} \quad \Delta \nabla \mathrm{DMM}+\mathrm{CTM}$

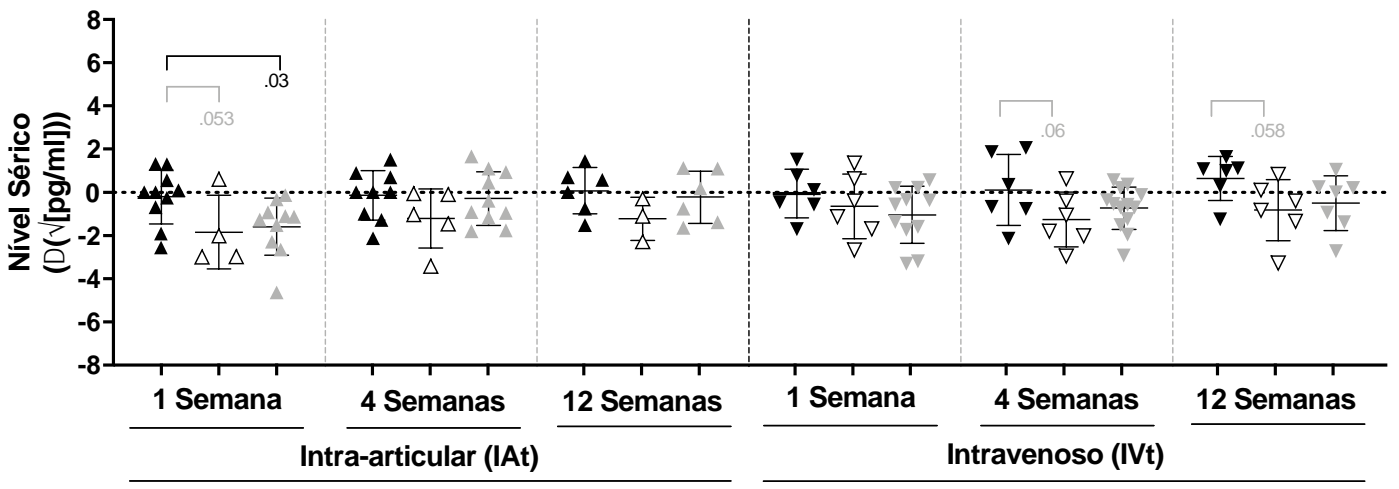

C

MCP-1

$\Delta \mathrm{DMM}+\mathrm{PLACEBO} \quad \triangle \nabla \mathrm{SHAM}+\mathrm{CTM} \quad \Delta \nabla \mathrm{DMM}+\mathrm{CTM}$

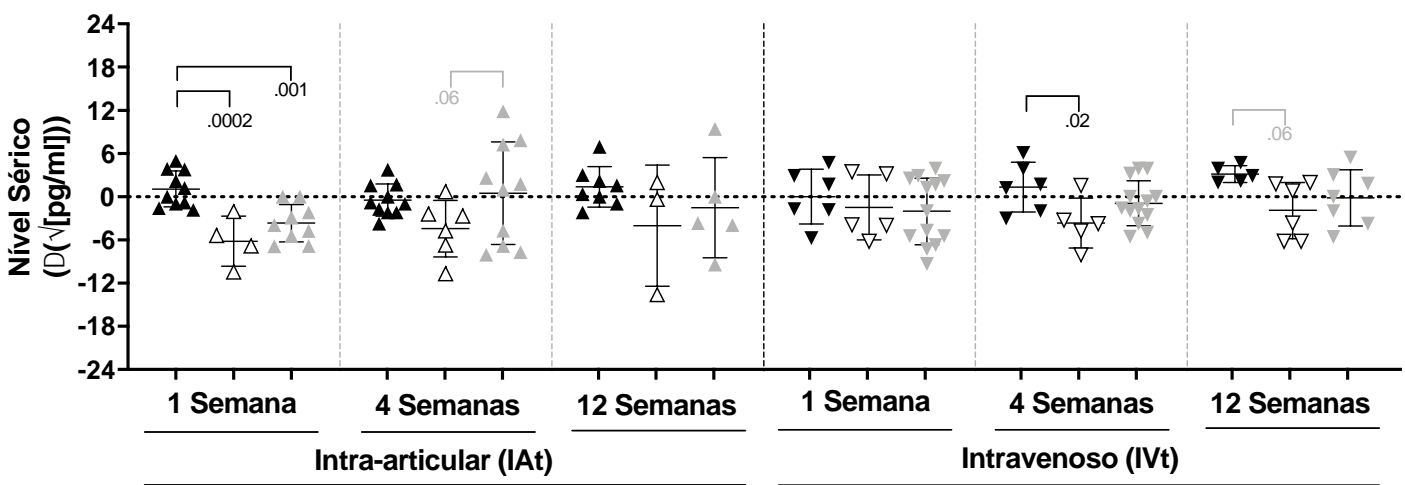

Análise após uma, quatro e 12 semanas do transplante celular intravenoso (IVt) ou intraarticula (IAt). Linha horizontal pontilhada representa o valor de referência do ponto anterior ao transplante (nove semanas após intervenção cirúrgica), pelo qual foi realizado o delta entre amostras. DMM: desestabilização do menisco medial; PLACEBO: cloreto de sódio 0.9\%; SHAM: cirurgia sem desestabilização do menisco medial; CTM: célula-tronco mesenquimal; Colchete preto: $p \leq 0,05$; Colchete cinza: $p>0,05$; N/A: Teste estatístico não aplicável $(\mathrm{N}<3)$.

Figura 59. Comparação de níveis séricos de IL-1ß, IL-18 e MCP-1, entre grupos 
A

MIP-1

A

$\mathrm{DMM}+\mathrm{PLACEBO} \quad \triangle \nabla \mathrm{SHAM}+\mathrm{CTM}$

$\mathrm{DMM}+\mathrm{CTM}$

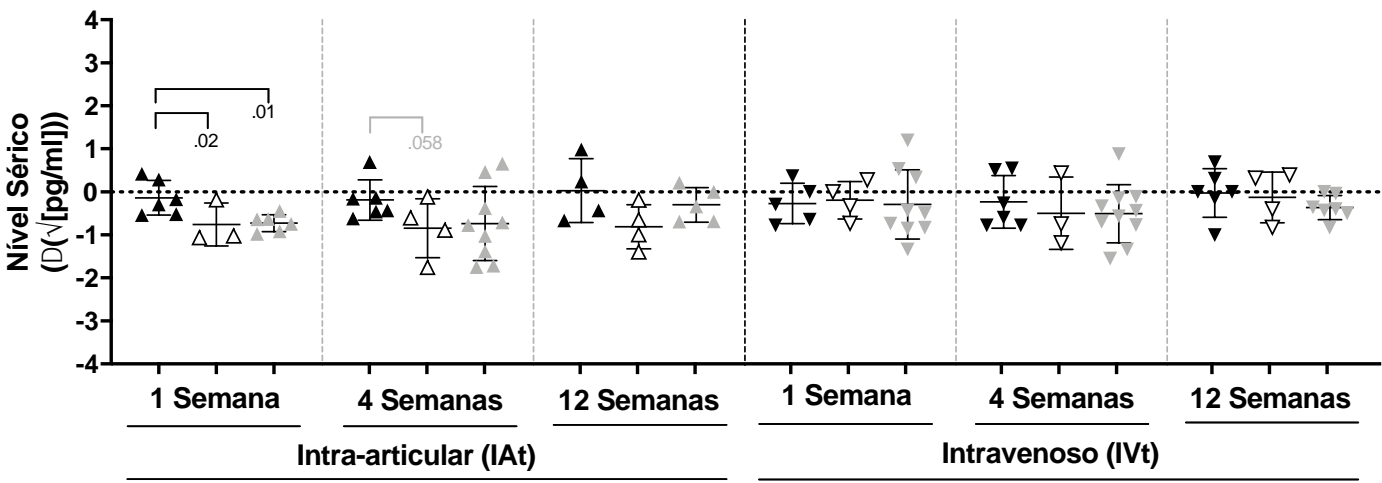

B

IL-10

$\Delta \nabla \mathrm{DMM}+\mathrm{PLACEBO} \quad \triangle \nabla \mathrm{SHAM}+\mathrm{CTM} \quad \Delta \nabla \mathrm{DMM}+\mathrm{CTM}$

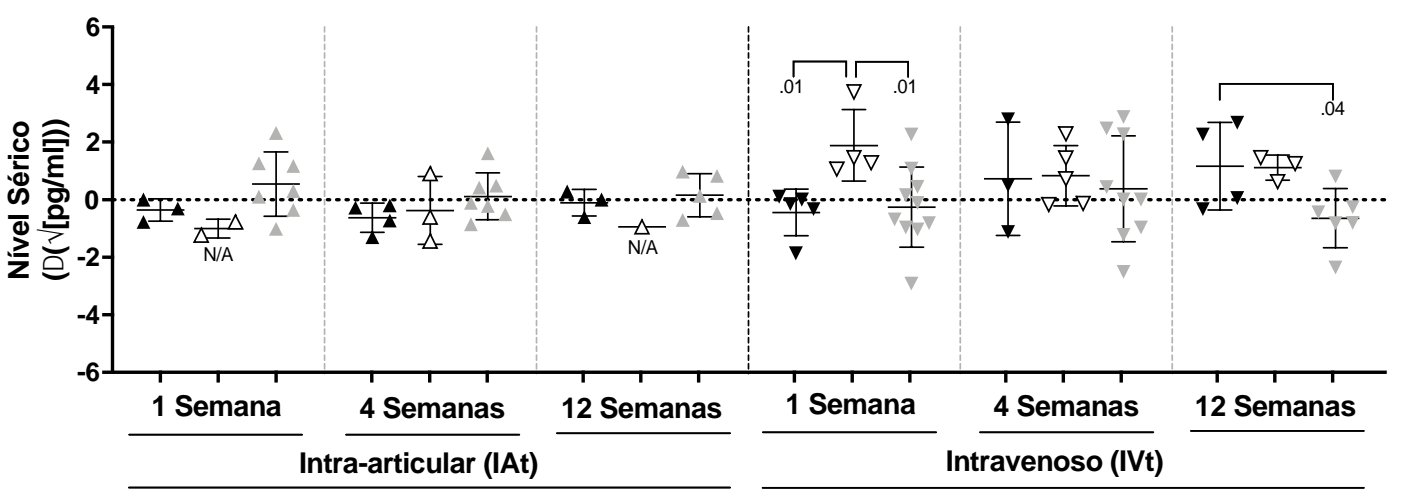

C

RANTES

$\Delta \mathrm{DMM}+\mathrm{PLACEBO} \quad \triangle \nabla \mathrm{SHAM}+\mathrm{CTM} \quad \Delta \nabla \mathrm{DMM}+\mathrm{CTM}$

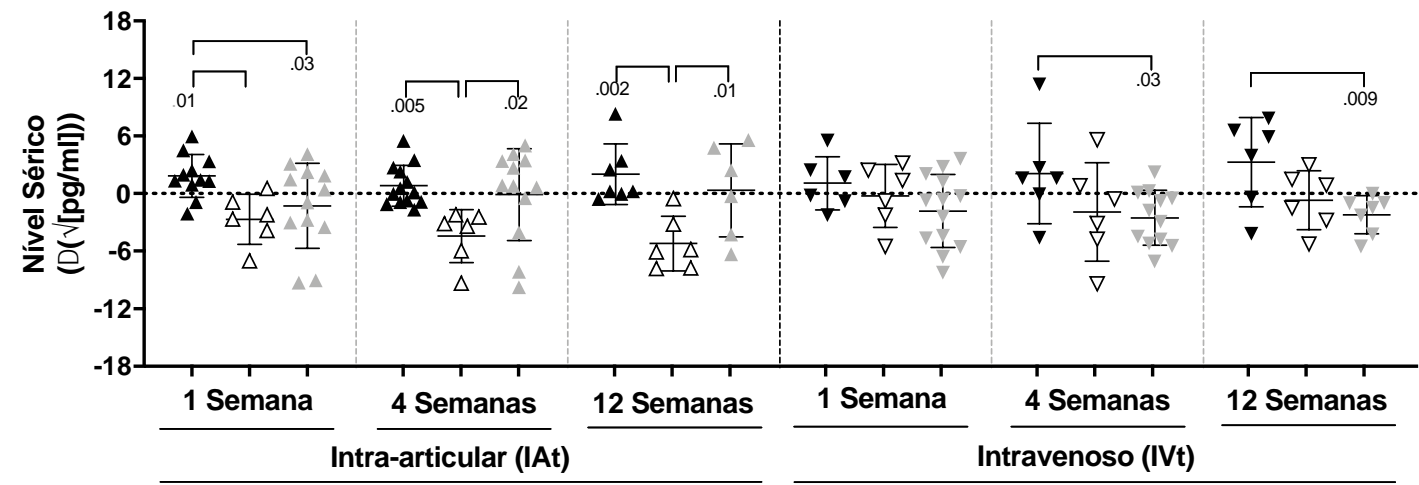

Análise após uma, quatro e 12 semanas do transplante celular intravenoso (IVt) ou intraarticula (IAt). Linha horizontal pontilhada representa o valor de referência do ponto anterior ao transplante (nove semanas após intervenção cirúrgica), pelo qual foi realizado o delta entre amostras. DMM: desestabilização do menisco medial; PLACEBO: cloreto de sódio 0.9\%; SHAM: cirurgia sem desestabilização do menisco medial; CTM: célula-tronco mesenquimal; Colchete preto: $p \leq 0,05$; Colchete cinza: $p>0,05$; N/A: Teste estatístico não aplicável $(\mathrm{N}<3)$.

Figura 60. Comparação de níveis séricos de MIP-1 1 , IL-10 e RANTES, entre grupos 
A

- Intra-articular (IAt)

IL-1

$\checkmark$ Intravenoso (IVt)

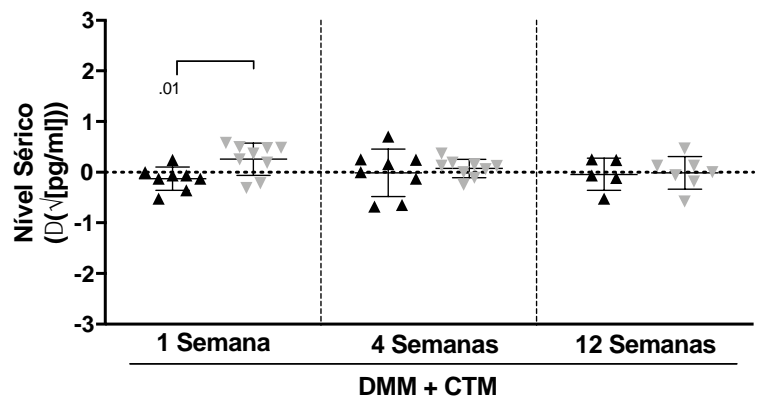

B

- Intra-articular (IAt)

IL-18

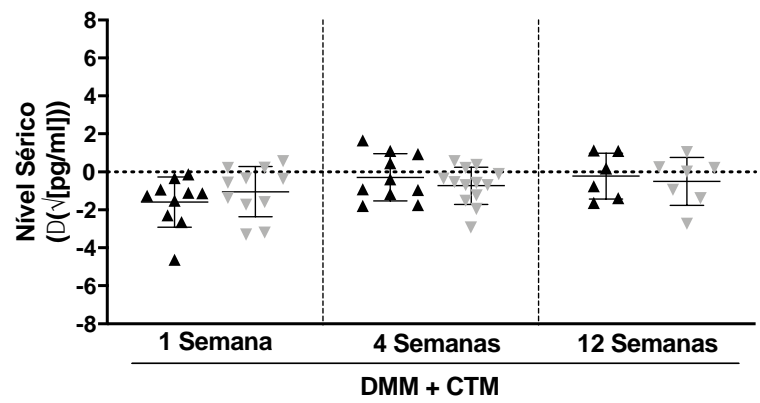

C

MCP-1

- Intra-articular (IAt)

$\nabla \quad$ Intravenoso (IVt)

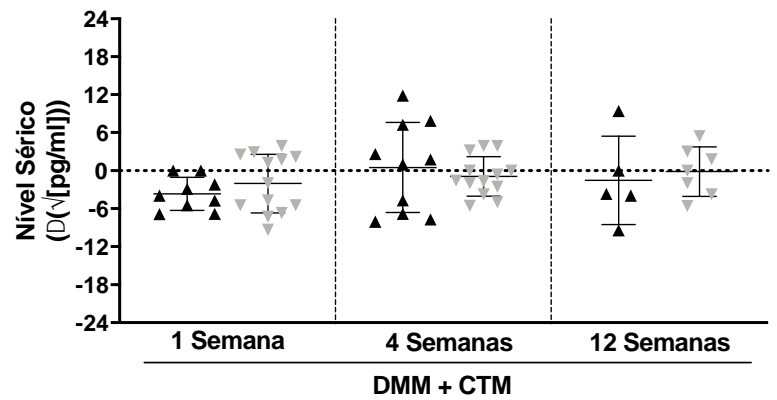

D

MIP-1

- Intra-articular (IAt)

Intravenoso (IVt)

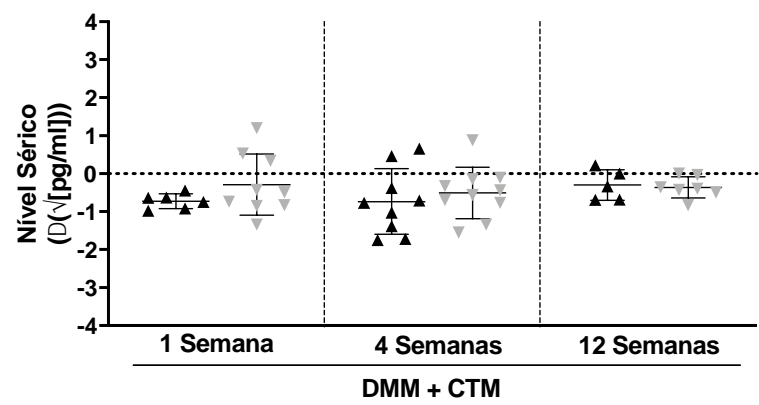

E

IL-10

\ Intra-articular (IAt) $\quad$ Intravenoso (IVt)

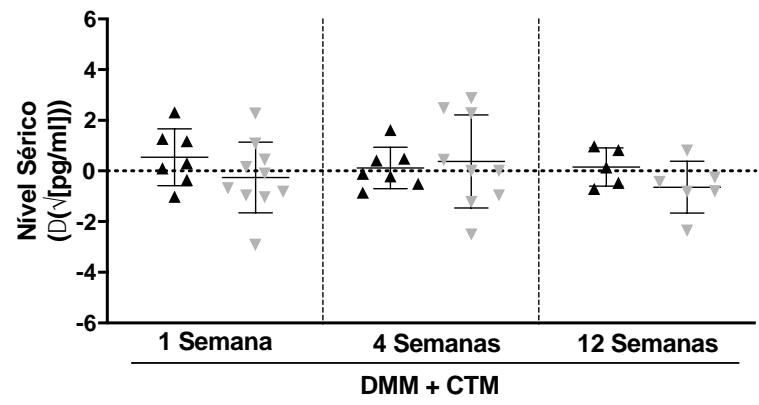

F

RANTES

\ Intra-articular (IAt) $\quad \nabla \quad$ Intravenoso (IVt)

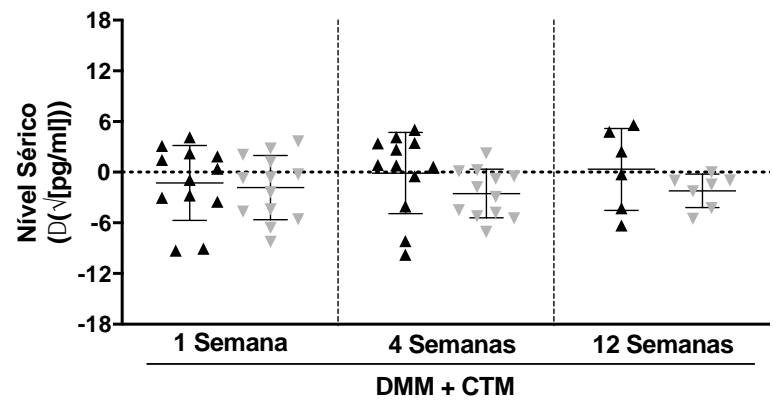

Análise após uma, quatro e 12 semanas do transplante celular intravenoso (IVt) ou intra-articula (IAt). Linha horizontal pontilhada representa o valor de referência do ponto anterior ao transplante (nove semanas após intervenção cirúrgica), pelo qual foi realizado o delta entre amostras. DMM: desestabilização do menisco medial; CTM: célula-tronco mesenquimal; Colchete preto: $p \leq 0,05$. IAt: intraarticular; IVt: intravenoso.

Figura 61. Comparação de níveis séricos de citocinas, com relação a via de transplante celular

\subsubsection{Perfil inflamatório do lavado sinovial}

Inicialmente, dentre todas as citocinas avaliadas, fez-se possível detectar sinais em poucas amostras, sendo esses, principalmente, da IL-18. Com o 
intuito de aumentar o potencial de detecção do ensaio, as amostras utilizadas se quantificaram à proteína total. A concentração de proteína em amostras, que tiveram detecção de citocinas, utilizou-se como parâmetro para determinar qual deveria ser a concentração mínima de proteína detectável pelo ensaio Luminex. Utilizando a IL-18 como referência, as amostras foram concentradas para $6 \mu \mathrm{g} / \mu \mathrm{L}$. Dessa forma, fez-se possível usar $150 \mu \mathrm{g}$ de proteína, em $25 \mu \mathrm{L}$ de suspensão, para o novo ensaio. Das 145 amostras iniciais, possibilitou-se a concentração 111 ao novo ensaio (Figura 62). De maior importância que o valor absoluto do nível de citocina em uma amostra constitui a quantidade de amostras detectáveis por citocina. Após a concentração das amostras de LS, as citocinas IL-1ß, IL-10, IL-18 e RANTES foram as que possibilitaram detecção a, ao menos, três animais dos grupos DMM+CTM-IAt e DMM+CTM-IVt, em quatro e 12 semanas.

A

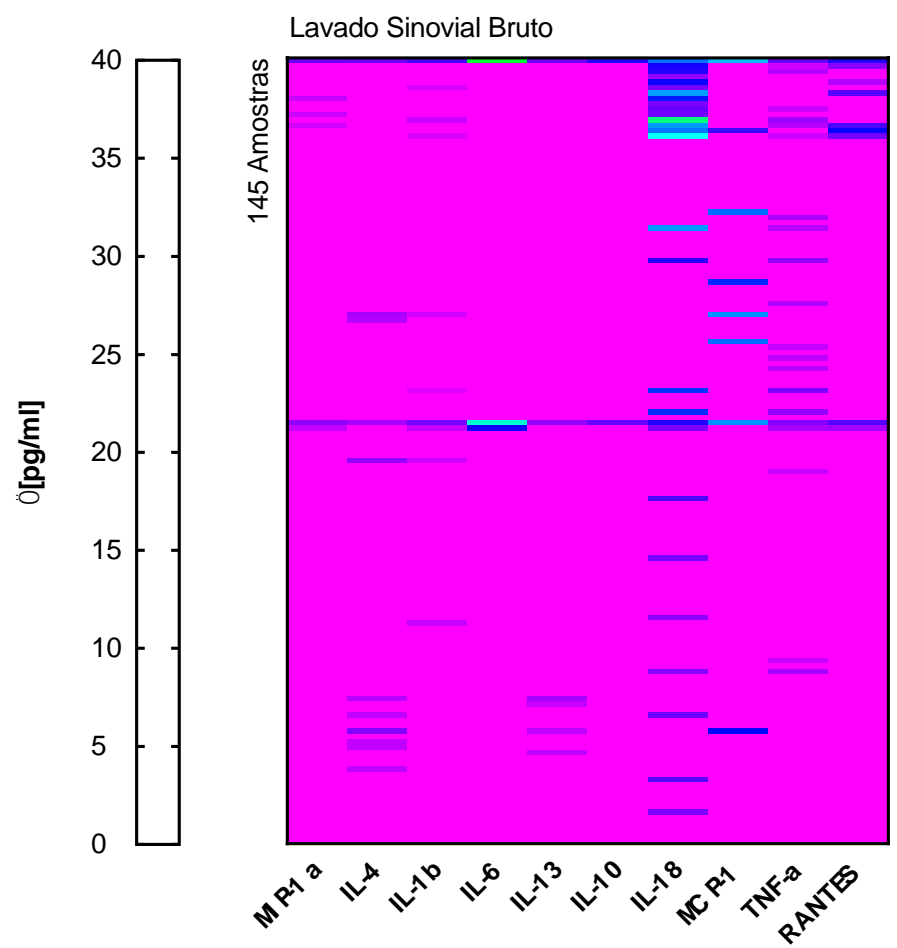

B

Lavado Sinovial Concentrado

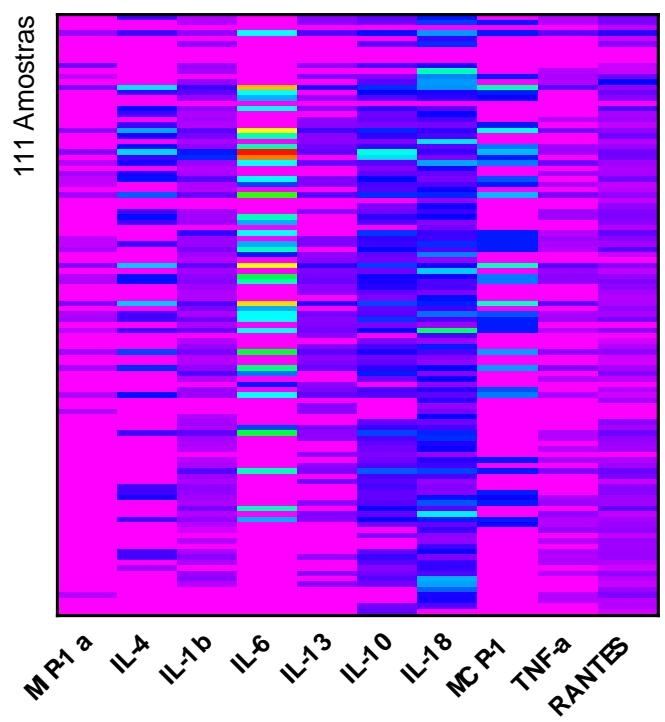

(A) antes e (B) depois do procedimento de concentração das amostras.

Figura 62. Heatmap do resultado global do ensaio Luminex para as amostras de lavado sinovial

As maiores alterações ocorreram, nos tempos de quatro semanas após o transplante. Os grupos que receberam células por IAt (SHAM+CTM-IAt-4S e $\mathrm{DMM}+\mathrm{CTM}-\mathrm{IAt}-4 \mathrm{~S})$ apresentaram valores mais baixos de IL-18 no LS, após quatro semanas, quando comparadas ao grupo placebo (DMM+PLACEBO-IAt-4S) (Figura 63). Não houve diferença entre outros grupos, citocinas, ou entre vias de transplante (Figura $64)$. 
A

IL-1

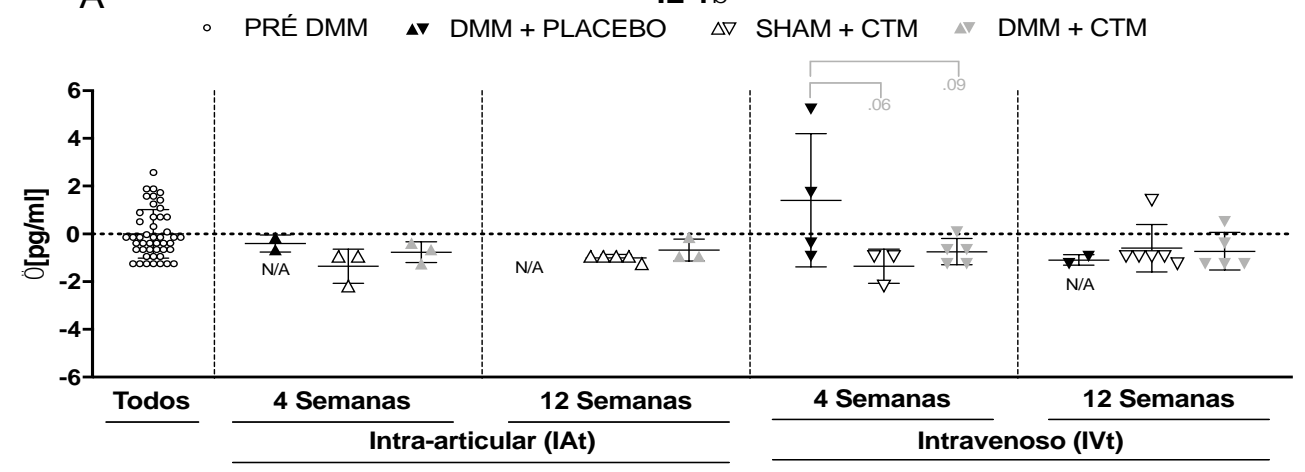

B

IL-18

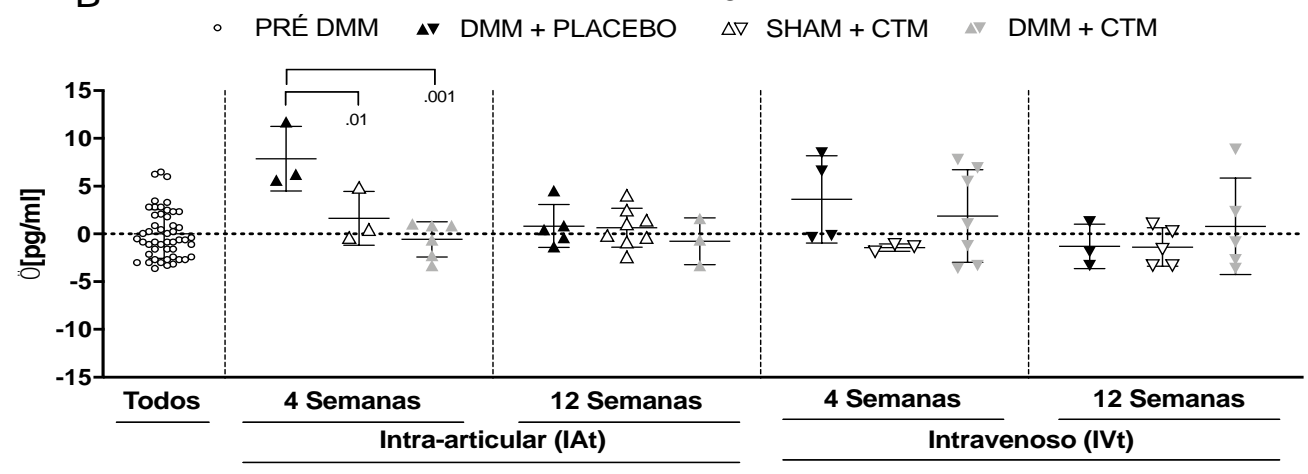

C

IL-10

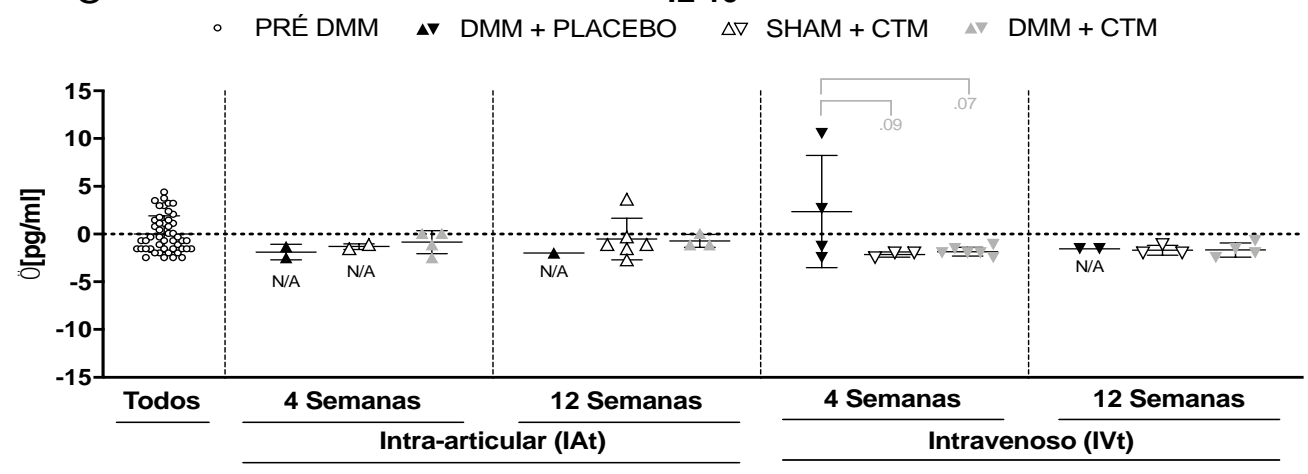

$\mathrm{D}$

RANTES

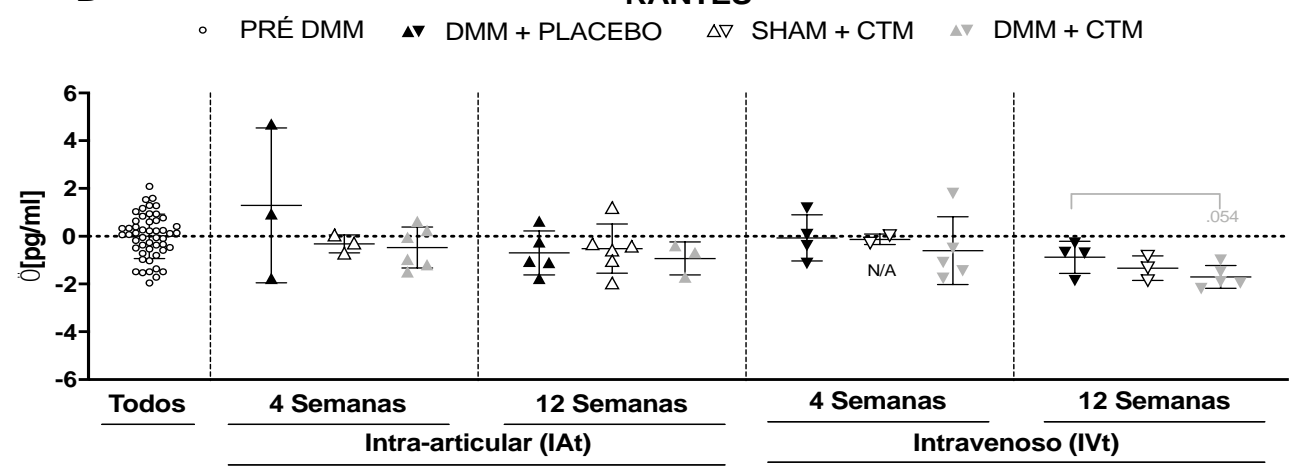

Análise após quatro e 12 semanas do transplante celular intravenoso (IVt) ou intra-articula (IAt). Linha horizontal pontilhada representa a média de referência do ponto anterior a cirurgia (PréDMM), utilizada para realizar o delta entre amostras. DMM: desestabilização do menisco medial; PLACEBO: cloreto de sódio $0.9 \%$; SHAM: cirurgia sem desestabilização do menisco medial; CTM: célula-tronco mesenquimal; Colchete preto: $p \leq 0,05$; Colchete cinza: $p>0,05$; N/A: Teste estatístico não aplicável $(\mathrm{N}<3)$;

Figura 63. Comparação dos níveis das citocinas IL-1ß, IL-18 IL-10 e RANTES no lavado sinovial concentrado 

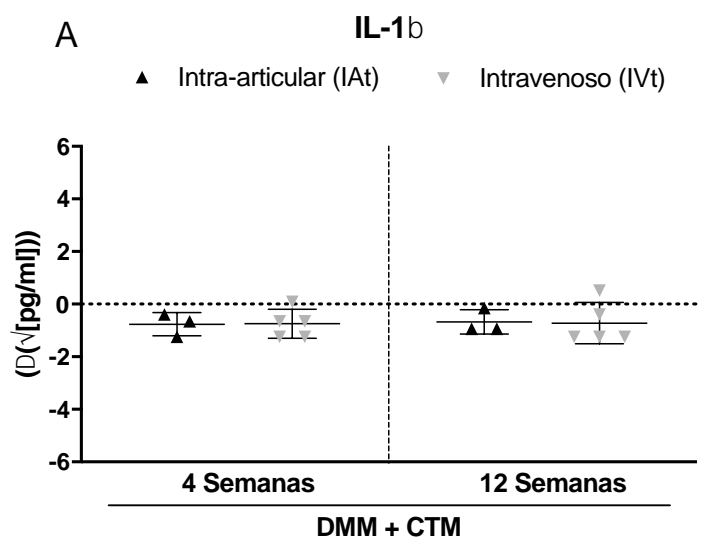

B

IL-18

- Intra-articular (IAt) $\quad$ v Intravenoso (IVt)

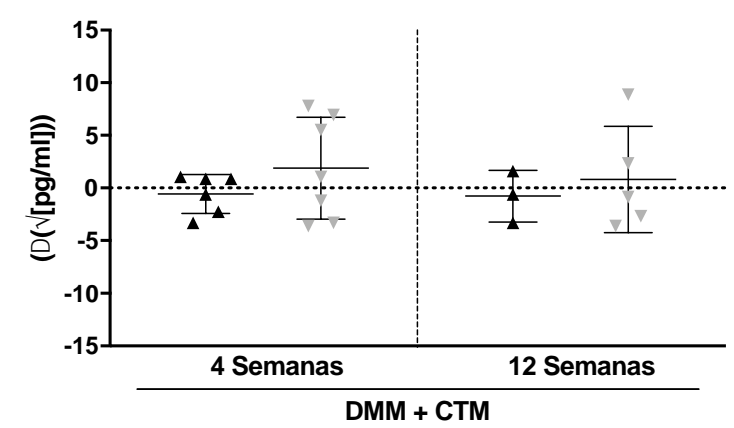

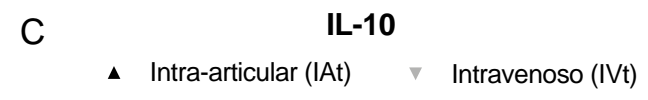

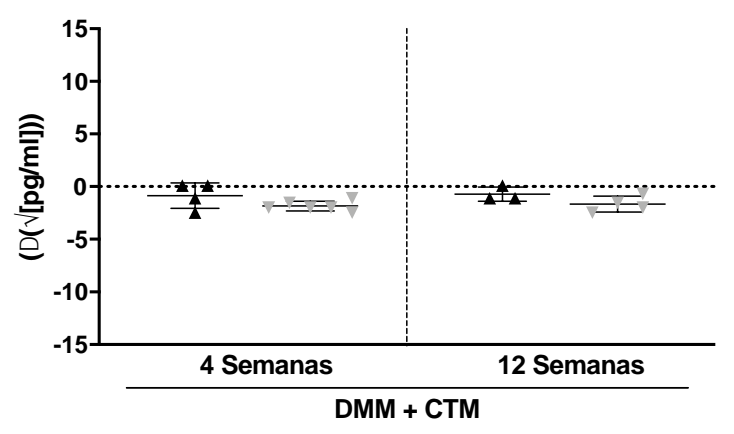

D

RANTES

- Intra-articular (IAt) $\quad \nabla \quad$ Intravenoso (IVt)

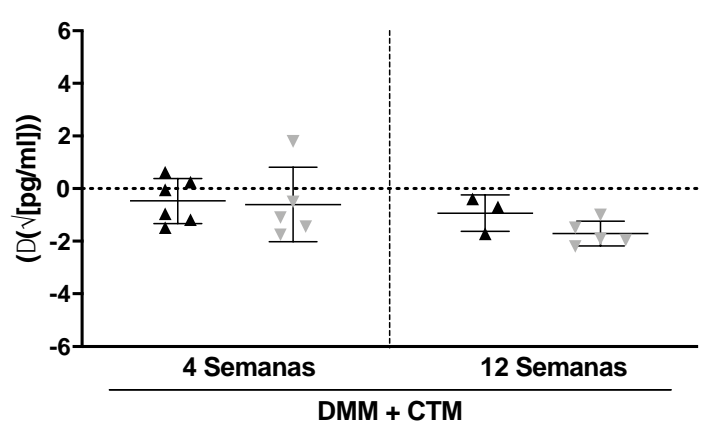

Análise após quatro e 12 semanas do transplante celular intravenoso (IVt) ou intra-articula (IAt). Linha horizontal pontilhada representa a média de referência do ponto anterior a cirurgia (PréDMM), utilizada para realizar o delta entre amostras. DMM: desestabilização do menisco medial; CTM: célula-tronco mesenquimal.

Figura 64. Comparação de níveis de citocinas, no lavado sinovial concentrado, com relação a via de transplante celular 


\section{DISCUSSÃO}

\subsection{Análise funcional, morfológica e sorológica do modelo animal}

Sabe-se que pacientes com OA apresentam redução de força muscular, atrofia do membro afetado e, consequentemente, função locomotora prejudicada. ${ }^{(107,108)}$ Com o intuito de auxiliar a interpretação dos resultados, após tratamento de OA por células-tronco mesenquimais, realizamos neste estudo alguns experimentos, com a finalidade de identificar aspectos morfológicos e biomecânicos do modelo animal de $\mathrm{OA}$, por $\mathrm{DMM}$ em ratos, nove semanas após o procedimento cirúrgico.

Não identificamos alterações nos dados cinemáticos e espaçotemporais da avaliação de marcha 2D. Sabe-se que alterações no padrão de marcha em pacientes com OA podem ser observadas, tanto em plano sagital (2D), quanto em relação a vetores de força sobre a articulação do joelho. O ângulo de flexão do joelho (AFJ), geralmente se encontra mais acentuado (i.e., joelho mais flexionado) em pacientes com OA, comparando-se com indivíduos saudáveis, principalmente quando analisado, durante a fase inicial da marcha de contato do calcanhar com o solo. Complementarmente, ao AFJ, o momento de flexão do joelho (MFJ), calculado pela associação entre análise cinemática e plataforma de força, apresenta valores menores, durante a fase de apoio da marcha, para membro com OA. A redução da MFJ, durante a fase de apoio, significa que o paciente com $O A$ adapta a marcha para depositar menor carga no membro afetado. ${ }^{(109,110)}$ Salvo as devidas limitações, a intensidade da pisada no teste CatWalk $^{\circledR}$ é uma maneira indireta de mensurar alterações similares ao MFJ. Contudo, também não identificamos diferenças entre os membros inferiores dos animais avaliados.

lijima et al. ${ }^{(111),}$ ao avaliar a marcha 2D, já haviam demonstrado que, após 4 semanas da cirurgia DMM, não se fez possível observar alterações cinemáticas e espaço-temporais da marcha, à articulação do joelho. Entretanto, os autores ressaltam que os animais também apresentavam cirurgia SHAM, no membro contralateral, e isso pode ter afetado a análise. Quanto as variáveis espaço-temporais, assim como em nosso trabalho, as coletas realizaram-se em esteira ergométrica, com velocidade fixa. Dessa forma, possivelmente, não correspondam à velocidade de 
deslocamento natural desses animais, e podem ter impedido a identificação de alterações mais sutis.

Ruan et al., ${ }^{(112)}$ utilizando-se do modelo animal, de OA por cirurgia de transecção do ligamento cruzado anterior (TLCA), encontraram alterações no padrão de pegada de camundongos em teste similar ao CatWalk ${ }^{\circledR}$. Quando comparado com o grupo SHAM, o TLCA apresentou menor área de contato da pegada do membro operado, após quatro, oito e 12 semanas da cirurgia. Também, Cunha et al., ${ }^{(113)}$ em 59 dias após TLCA em ratos, encontraram valores menores de comprimento e área da pegada, bem como comprimento da passada ao membro operado, comparando-se com um grupo de controle não operado. No entanto, faz-se necessário ressaltar que o modelo utilizado por esses estudos apresenta-se mais agressivo e de evolução mais rápida $^{(98)}$ do que o DMM. Também, as comparações, no presente estudo, ocorreram entre membros inferiores do mesmo animal e não com outros grupos. Apesar das variáveis analisadas serem diferentes, a intensidade da pegada normalizou-se, tanto pela massa corporal, quanto pela AMP e, mesmo assim, não identificamos diferenças entre membros.

Com relação a performance física desses animais, aparentemente, o teste de escalada não apresentou desafio suficiente, a fim de que a realização da tarefa fosse prejudicada, uma vez que melhoraram a performance, ao longo do tempo, independente do tipo de cirurgia. Também, devemos considerar que alterações no desenvolvimento físico do animal, bem como aprendizagem contínua da tarefa podem ter contribuído para esse resultado.

Já no teste incremental $\operatorname{Rotarod}^{\circledR}$, após o desenvolvimento de OA por DMM, os animais reduziram o tempo de permanência no aparelho, comparando-se com as coletas, realizadas antes da cirurgia. A principal diferença entre esse e o teste

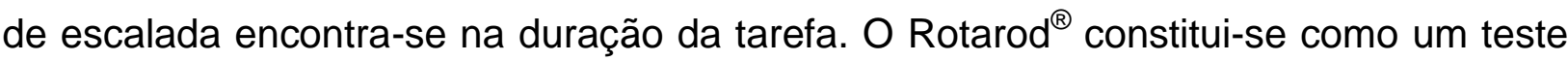
incremental e a performance decorrente do esforço máximo. Sendo assim, pode ter sido mais eficiente em detectar pequenas alterações motoras. Apesar da performance do grupo SHAM não ter sido diferente entre avaliações (pré e pós-cirúrgicas), essa também não se mostrou diferente do grupo DMM, após nove semanas. Como se faz possível observar no estudo de Ruan et al., ${ }^{(112)}$ além de encontrar diferença entre avaliações (pré e pós-cirúrgicas), eles também encontraram diferença entre grupos SHAM e TLCA, em quatro, oito e doze semanas após cirurgia. Entretanto, é possível observar oscilações do grupo SHAM e aproximação entre grupos em algumas coletas. 
Sendo assim, é possível que a própria cirurgia SHAM promova pequenas alterações funcionais e/ou os animais com $\mathrm{OA}$, se adaptem às próprias limitações e aumentem a performance.

Alterações neuromusculares podem ser uma das responsáveis por modificar a performance no teste Rotarod ${ }^{\circledR}$. Van der Poel et al., ${ }^{(114)}$ mostraram que, em uma semana, pós-cirurgia DMM ou SHAM em camundongos (C57BL/6), ocorre redução da força tetânica e de contração muscular do tibial anterior. Além disso, após quatro e oito semanas ao grupo DMM, ocorre também a redução da capacidade de gerar força e de relaxamento, após contração muscular do tibial anterior. Eles atribuem tal efeito, em parte, à redução da expressão do mRNA Atp2a1, que poderia estar prejudicando o processo celular, associado a recaptação $\mathrm{Ca}^{2+}$ após a contração. Porém, eles não observaram diferença na área de secção transversa das fibras musculares do tibial anterior, entre os grupos SHAM e DMM. Por outro lado, Cunha et al., ${ }^{(113)}$ com o modelo de OA por TLCA, encontraram atrofia de 15,7\% e 33\% de área de seção transversa do quadríceps e tibial anterior, respectivamente, em comparação com o grupo controle. Nesse estudo, eles também encontraram redução da área e perímetro de junções neuromusculares. Ambas as modificações neuromusculares podem estar associadas ao aumento da expressão proteica de MURF-1, encontrada neste modelo animal de OA.

Apesar de não possuirmos valores de peso muscular, em nove semanas após a cirurgia, os dados dos grupos CON-13S e CON-21S podem servir como indicativo da progressão do modelo animal. Sendo assim, a diferença de peso muscular, identificada no quadríceps, gastrocnêmio/sóleo e tibial, anterior do MIOA, em comparação com os respectivos músculos do MICL, indicam indiretamente um processo de atrofia muscular presente nesses animais.

Além das alterações funcionais e musculares, o modelo animal de DMM também ocasiona extrusão ${ }^{(115)}$ e calcificação ${ }^{(116)}$ do menisco medial características também presentes em pacientes com OA. ${ }^{(117,118)}$ Por intermédio da radiografia dos animais, nove semanas após a cirurgia, essas duas alterações do menisco medial foram os sinais radiográficos mais evidentes observados. Apesar de a análise ser apenas qualitativa, ela pode servir como uma alternativa in vivo, não invasiva de identificação da presença do processo de OA, após o procedimento cirúrgico. 
A avaliação sorológica, de 44 animais, permitiu analisar de forma pareada (Pré e Pós-DMM), citocinas e quimiocinas - presentes no soro dos animais, demonstrando que, em nove semanas após cirurgia, houve aumento de MIP-1a. A MIP-1a (macrophage inflamatory protein), também conhecida como Chemokine (C-C motif) Ligand 3 (CCL3), é uma quimiocina pró-inflamatória envolvida na quimioatração de macrófagos e monócitos. ${ }^{(119)}$ Considera-se a referida molécula um biomarcador sanguíneo, representativo do estado inflamatório articular de OA em humanos. ${ }^{(120,121)}$ Zhao et al. ${ }^{(121)}$ foram os primeiros a mostrar que, dentre outras, MIP-1 $\alpha$ constitui a quimiocina, que melhor discrimina pacientes, com e sem $O A$, além de ser a que apresenta maior correlação com dados de radiografia, analisados pela escala de Kellgren and Lawrence.

Associando as informações obtidas, podemos dizer que o modelo animal de DMM é de progressão lenta, com características semelhantes a fisiopatologia da OA em humanos.

\subsection{Estudo agudo}

Este estudo permitiu observar a cinética de citocinas e a viabilidade metabólica celular, durante a primeira semana após o IAt e ou IVt.

Utilizando $2 \times 10^{6}$ células $/ \mathrm{kg}$, demonstramos que, após o IAt, as CTMs permanecem metabolicamente ativas, dentro da articulação, por ao menos uma semana. Alguns estudos já haviam demonstrado a detecção in vivo de CTMs, após IAt. Li et al. ${ }^{(122)}$ conseguiram detectar CTMs transplantadas na articulação do joelho, por até dois meses, em modelo animal de OA, por cirurgia de menisectomia em ratos. No estudo em questão, utilizaram-se células-tronco mesenquimais humanas (hCTMs), marcadas com partículas fluorescentes (DiD) $\left(2,5 \times 10^{6}\right.$ células/animal; $\approx 7-10 \times 10^{6}$ células $/ \mathrm{kg}$ ). Similarmente, Shim et al.,(123) também usando marcação fluorescente (PKH67) de hCTMs, conseguiram detectar as células in vivo, por até 21 dias, em modelo animal de lesão articular, por iodoacetato monosódico (IAM), em camundongos $\left(5 \times 10^{5}\right.$ células/animal; $\approx 20 \times 10^{6}$ células $\left./ \mathrm{kg}\right)$. Apesar do longo período de detecção in vivo, comparações entre resultados devem ser realizadas com cautela, pois existem algumas diferenças importantes, com relação ao modelo animal, número e tipo celular utilizado. 
Embora não tenhamos avaliado o sinal de luminescência, após uma semana, observamos uma redução de 93\%, entre a primeira (duas horas) e última avaliação (1S) após transplante, sendo que, mais da metade desta (57,8\%) ocorreu nas primeiras 24 horas. Interessantemente, Shim et al. ${ }^{(123)}$ também observaram redução do sinal de fluorescência, entre, aproximadamente, 50\% e 65\%, após um dia e uma semana do transplante celular, respectivamente. Tal diferença entre sinais in vivo, após uma semana, pode ser também devido a especificidade do método de detecção, uma vez que partículas fluorescentes em fragmentos celulares também são detectáveis, enquanto para ocorrer luminescência a célula precisa estar viável e metabolizar luciferina.

Não há possibilidade de se chegar a uma conclusão sobre os dados de detecção in vivo, apresentados por Li et al., ${ }^{(122)}$ durante a primeira semana após IAt, pois eles observaram um aumento do sinal nos primeiros sete dias, o que não seria possível, considerando que, apesar das células poderem proliferar, o marcador fluorescente não se multiplica. Eles atribuem tal efeito à variabilidade entre os animais coletados.

Ozeki et al., ${ }^{(124)}$ utilizando um modelo de OA por cirurgia de transecção do cruzado anterior e CTMs isoladas da membrana sinovial, avaliaram o sinal de luminescência, ao longo de quatro semanas, após um único transplante ou transplante seriado semanal IA ( $1 \times 10^{6}$ células/animal; $\approx 3,3-4 \times 10^{6}$ células $\left./ \mathrm{kg}\right)$. Apesar de não terem realizado avaliação, logo após o transplante, demonstraram que, entre um dia e uma semana, há redução importante do sinal, desaparecendo quase que completamente, em duas a três semanas. Também, o transplante seriado não teve efeito cumulativo na intensidade da luminescência, porém manteve o sinal equivalente a avalição de uma semana, após o primeiro transplante.

Em estudo recente, Satué et al. ${ }^{(125)}$ observaram, por análise histológica, que, um dia após o IAt, em modelo animal de lesão focal da cartilagem, as células transplantadas $\left(10 \times 10^{6}\right.$ células/animal; $\approx 25-30 \times 10^{6}$ células $\left./ \mathrm{kg}\right)$ encontram-se, majoritariamente, em pequenos agregados celulares no líquido sinovial $(16,9 \pm 3,5 \%)$, sendo que, após uma semana, esse número se reduz significativamente $(1,5 \pm 0,4 \%)$.

Independentemente das diferenças entre os estudos, o tempo de decaimento, da maior parte do sinal de CTMs, parece ser consistente, ocorrendo em uma semana e, principalmente, em 24 horas após IAt. Esses dados evidenciam que a 
ação destas células, dentro da articulação lesionada, é, principalmente, transiente e parácrina.

Diferentemente do transplante IA, o homing de CTMs, após transplante sistêmico (intravenoso), em modelo animal de OA leve, ainda se encontra desconhecido. A otimização da técnica possibilitou a captação do sinal de luminescência na região da lesão (joelho operado), oito horas após o transplante em um dos quatro animais avaliados. Entretanto, nenhum sinal detectou-se, 24 horas após o transplante. Utilizando técnicas ex vivo de citometria de fluxo por imagem e microscopia confocal, possibilitou-se encontrar células duplamente marcadas, nas estruturas do pulmão e joelho dos animais avaliados. Apesar desses resultados serem discretos, devido ao $\mathrm{N}$ amostral, ao nosso conhecimento, esse constituiu o primeiro estudo que observou indícios de homing de CTMs à articulação afetada por OA leve.

Encontramos na literatura, utilizando a estratégia: "(Arthritis) AND intravenous) AND stem cells" 42 artigos, dentre os quais apenas dois realizaram transplante de células-tronco mesenquimais, de forma intravenosa, em modelo animal de lesão da $\mathrm{CA}^{(126,127)}$ sem a administração de químicos (colagenase; IAM). Esses últimos geram o desgaste da cartilagem, em conjunto com elevado quadro inflamatório, caracterizando tais modelos, de forma mais semelhante a artrite reumatoide. ${ }^{(70)}$ Fernandez-Pernas et al. ${ }^{(126)}$ mostraram que CTMs CD105 ${ }^{+}$isoladas da membrana sinovial de humanos, se mostraram capazes de migrar para a articulação do joelho de macacos, com defeito osteocondral gerado cirurgicamente. As principais diferenças desse estudo são as características do transplante realizado. As CTMs extraídas da membrana sinovial apresentam maior potencial condrogênico, ${ }^{(128)}$ além de serem um subtipo $\left(\mathrm{CD} 105^{+}\right)$menos heterogêneo, podendo ter maior especificidade do que células extraídas da medula óssea. $O$ número de células utilizado, também foi maior $\left(10 \times 10^{6}\right.$ células; $\approx 5 \times 10^{6}$ células $/ \mathrm{kg}$ ). Apesar de ser um modelo animal, sem grande processo inflamatório envolvido, realizou-se o transplante celular, durante o procedimento cirúrgico. Dessa forma, se faz bastante provável que as células se direcionaram à região do joelho, após o IVt, devido a sinalização gerada pela lesão cirúrgica, facilitando o acesso dessas células a lesão da cartilagem.

Olsen et al., ${ }^{(127)}$ em um estudo piloto recente, com cachorros

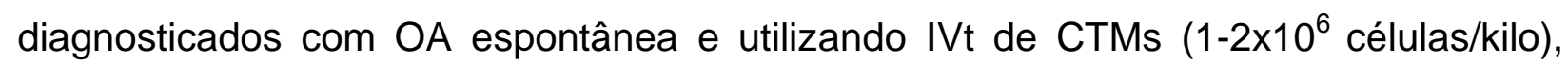
marcadas com partículas fluorescentes (DiD), relatam ter encontrado células marcadas 
no líquido sinovial, em 24 horas após o transplante. Contudo, não apresenta imagens ou dados quantitativos que sustentem tal afirmação.

De acordo com a análise do nível sérico de citocinas, o aumento do nível de MIP-1a, após o desenvolvimento do modelo animal, pode ter sido um dos responsáveis por atrair essas células ao joelho com OA. Isso, pois as células mesenquimais expressam o receptor $C$ - $C$ chemokine receptor type 1 (CCR1), um dos receptores para MIP-1a - uma das quimiocinas capazes de promover migração de CTMs. ${ }^{(93,129,130)}$

Considerando que, para observar o homing de células para o joelho, necessário se fez transplantar uma dose celular maior $\left(4 \times 10^{6}\right.$ células $\left./ \mathrm{kg}\right)$ do que a terapêutica e que, mesmo assim, o sinal detectado foi baixo, acreditamos que a barreira pulmonar ocasionada pelo acúmulo de células no pulmão não tenha permitido, nos outros três animais, passagem suficiente de células para ser detectado pelo ensaio de luminescência, ou o tempo do evento tenha sido diferente de oito horas.

Interessantemente, as imagens da citometria mostram que os eventos positivos detectados no pulmão e joelho, variam entre células inteiras, fragmentos celulares livres ou presentes no interior de outras células. Também, identificamos a formação de estruturas semelhantes a vesículas extracelulares (VEs), ao redor das células acumuladas no pulmão. As VEs fazem parte dos subprodutos presentes no secretoma de CTMs e, também, apresentam potencial regenerativo. ${ }^{(131)}$ Há um crescente número de trabalhos sobre o uso de VEs no tratamento de OA em modelos pré-clínicos ${ }^{(132)}$ com IAt. Contudo, no experimento em questão, após IVt, parece-nos mais provável que esses fragmentos sejam uma resposta aguda da interação das células, transplantadas com células do sistema imune, como monócitos e macrófagos, devido a obstrução ocasionada. ${ }^{(133,134)}$ Com a finalidade de melhor interpretar este fenômeno, seria necessário isolar e caracterizar estes fragmentos.

O efeito imunossupressor das células-tronco mensenquimais é amplamente conhecido. ${ }^{(43,57)}$ Sabe-se que, para essas células terem um papel eficaz no local do implante, precisam ser "licenciadas", isto é, precisam ser expostas a sinalização de citocinas inflamatórias, principalmente IL-1 e Interferon gamma (IFNy). Quando tais células são transplantadas em microambientes, com presença de inflamação, produzem um secretoma que, dentre outras funções, tem o papel de atrair células do sistema imune ao tecido em questão. Parte importante dessa resposta, 
imunomoduladora por CTMs, ocorre após a fagocitose dessas células por monócitos e macrófagos. ${ }^{(135-137)}$

Os dados de citometria de imagem demonstram a presença de CTMs fagocitadas. Embora não seja possível identificar o tipo celular que realizou tal ação, o aumento de MIP-1a e IL-10 nas primeiras $2 \mathrm{H}$, após IVt, indicam a ação de macrófagos, possivelmente devido ao acúmulo de células nos capilares alveolares. A IL-10 consiste em uma citocina anti-inflamatória produzida por macrófagos, células TH1, TH2, entre outras, do sistema imune. ${ }^{(138)}$ Nenasheva et al., ${ }^{(139)}$ mostraram que, após transplante de CTMs via intravenosa em camundongos saudáveis, ocorre, entre outros, o aumento de MIP-1a e IL-10. Esse aumento abrupto dessas duas moléculas com funções opostas, pode ser explicado pela ação sistêmica de feedback loop, negativo a atividade exacerbada dos macrófagos, para manter a homeostase local. ${ }^{(138)}$

O referido mecanismo de ação, baseado na atração, fagocitose e ativação das células no local da lesão, também explicaria os resultados obtidos no ensaio de luminescência e nos níveis séricos de citocinas, no caso do IAt. A redução do sinal de luminescência, no período de 24 horas, em comparação com os dias seguintes, após IAt (uma semana), coincide com as diferenças encontradas na concentração de IL-18, MCP-1 e RANTES para o mesmo período de tempo. RANTES é uma quimiocina, Chemokine (C-Cmotif) Ligand 5 (CCL5) produzida, principalmente, por células $\mathrm{T} C D 8^{+}$em resposta a sinais de inflamação. Também secretada por CTMs, após estímulo por IFNy ou TNFa, ${ }^{(140)}$ responsabiliza-se por atrair leucócitos que irão infiltrar o tecido lesionado. ${ }^{(141)} \mathrm{MCP}-1$ é uma quimiocina, Chemokine ( $C-C$ motif) Ligand 2 (CCL2), abundantemente produzida por CTMs, sendo responsável pela atração de macrófagos e monócitos. ${ }^{(142)}$ Interessantemente, a produção de MCP-1 por CTMs também pode agir como um antagonista da quimiotaxia e ativação de células $T .^{(143)}$ Considerando, ainda, o comportamento da curva de concentração sérica, para estas duas quimiocinas, parece haver uma regulação temporal entre a produção RANTES e MCP-1, a partir das CTMs após IAt.

A diferença entre citocinas e quimiocinas, reguladas após IVt e IAt, ocorre, provavelmente, devido ao fato de as células administradas via IAt entrarem em contato, diretamente, com um ambiente inflamatório pré-existente, o qual vai as estimular a atuar, enquanto que, pela via $\mathrm{IVt}$, as células acumuladas no pulmão, rapidamente produzem e sofrem a ação de macrófagos alveolares. ${ }^{(137)}$ 
De forma geral, todas as quimiocinas aumentadas, após 0 transplante, foram reguladas para baixo, após uma semana. A IL-18 constitui uma citocina pró-inflamatória, também conhecida como "fator indutor de IFNy", ${ }^{(144)}$ da família da IL-1 e, principalmente, produzida por macrófagos, bem como por outras células apresentadoras de antígeno. ${ }^{(145)}$ A redução de IL-18, para ambos os grupos, após uma semana, apresenta-se como um bom indicador para confirmar que as células ocasionaram um efeito imunossupressor.

\subsection{Estudo longitudinal}

Demonstramos neste trabalho não ser suficiente um único transplante de CTMs, a fim de impedir o avanço do desgaste da CA.

Quando se propõe o uso de um novo tratamento para determinada patologia, seja esse medicamentoso ou biológico, faz-se necessário, inicialmente, realizar ensaios experimentais pré-clínicos. Por esse motivo, o desenho experimental deve ser feito, de forma a representar o mais próximo possível do cenário clínico real. A avaliação e determinação do início da OA constitui um desafio, pois em geral sua progressão é lenta e o momento em que o paciente procura o médico, por dores, rigidez ou inchaço articular, o desgaste da CA já está instalado. ${ }^{(24,120)}$ Sendo assim, o modelo pré-clínico deve levar em conta, tanto o tipo de indução de OA como o momento em que as células são administradas.

Analisando a literatura sobre o uso de células-tronco no tratamento de OA, observamos existirem algumas questões importantes, explicativas das diferenças entre os resultados que encontramos e estudos que descrevem efeitos benéficos das CTMs, ao tratamento de OA. ${ }^{(69)}$ Dentre elas, o perfil inflamatório de cada modelo e como esse quadro se encontra, no momento do transplante celular, parecem ser importantes, a fim de que ocorra o controle da progressão da degeneração da cartilagem.

Interessantemente, Huurne et al. ${ }^{(146)}$ demonstraram a impossibilidade de proteção contra a patologia articular, quando as células foram administradas tardiamente. Em tal estudo, eles utilizaram modelo de degeneração da cartilagem, induzido por administração de colagenase IA e transplantaram as CTMs $\left(2 \times 10^{4}\right.$ células/animal; $\approx 0,8 \times 10^{6}$ células $\left./ \mathrm{kg}\right)$ poucos dias após a lesão ( 7 dias) ou 
tardiamente (14 dias). Os autores sugerem ser a diferença encontrada, devida principalmente ao momento em que houve a interação das CTMs, e a resposta inflamatória inicial, gerada pelo modelo animal. De fato, Van Lent et al. ${ }^{(147)}$ mostraram que, entre sete e 14 dias após administração de colagenase IA, a resposta inflamatória se mostra bastante elevada, reduzindo em 21 dias.

Schelbergen et al., ${ }^{(72)}$ utilizando dois modelos animais: um, classificado como sendo de alta ativação sinovial (colagenase), e outro, de baixa

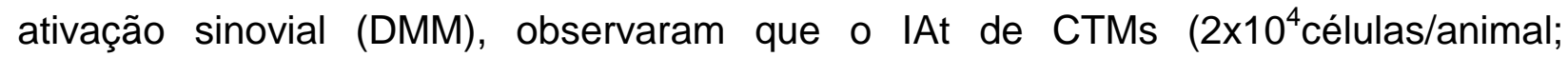
$\approx 0,8 \times 10^{6}$ células $/ \mathrm{kg}$ ), sete dias após a lesão (colagenase) foi suficiente para impedir inflamação da sinóvia e danos articulares, por até 42 dias. Porém, o mesmo não aconteceu quando o transplante foi realizado, em sete ou 14 dias após indução do modelo de DMM, e analisado após sete e seis semanas, respectivamente. Eles justificam que, para as CTMs exercerem um efeito anti-inflamatório importante, faz-se necessário haver um determinado liminar pró-inflamatório, presente na articulação.

Também, Enomoto et al. ${ }^{(148)}$ testaram o potencial regenerativo das CTMs, em função do tempo (zero, uma ou duas semanas) em que ocorreu o transplante $\left(1 \times 10^{6}\right.$ células/animal; $\approx 3,3-4 \times 10^{6}$ células $\left./ \mathrm{kg}\right)$, após a lesão da cartilagem. Utilizando um modelo de lesão focal parcial da CA, observaram que o transplante celular teve capacidade regenerativa, apenas quando realizado próximo do procedimento cirúrgico (zero semanas). Entretanto, não quando realizaram após uma ou duas semanas. Sugerem, ainda, a importância de um estado inflamatório inicial, à atuação das células, e que, em um ambiente clínico, talvez seja necessário realizar o desbridamento da lesão focal, antes do transplante.

Outros pontos importantes a serem considerados são a evolução de cada modelo, bem como o tempo entre transplante e coleta. Enquanto modelos de colagenase ou lesão focal apresentam um período fixo pró-inflamatório, modelos cirúrgicos apresentam degeneração progressiva da lesão. Um exemplo desse aspecto progressivo é o modelo animal de DMM. Nele, há uma grande modulação gênica, durante as quatro primeiras semanas após a cirurgia, porém, em oito semanas, ocorre a estabilização da expressão de genes relacionados a proliferação celular e modelação de matriz extracelular. Esse período estável se reverte, e a regulação gênica volta a aumentar, após 16 semanas, juntamente com a progressão do desgaste da CA. ${ }^{(73)}$

Em contraste com Schelbergen et al., ${ }^{(72)}$ outro estudo que encontrou efeito do tratamento de CTMs, após modelo de DMM, ${ }^{(149)}$ utilizou um número maior de 
células $\left(1 \times 10^{6}\right.$ células/animal; $\approx 40 \times 10^{6}$ células $\left./ \mathrm{kg}\right)$. O tempo entre transplante e coleta também foi menor, entre quatro e oito semanas após cirurgia, respectivamente. Essa diferença em relação ao tempo, entre transplante e coleta, também já se observou, após modelo de ACLT. ${ }^{(150)}$ Ao que aparenta, efeitos positivos obtidos pelas CTMs, são sobrepostos pela progressão da degeneração articular ao longo do tempo.

Como discutido anteriormente (Item 6.2), a ação das CTMs parece ter um papel transiente. Tendo em vista tal fato, talvez transplantes seriados sejam uma forma de manter o equilíbrio pró e anti-inflamatório, durante a progressão da OA. De fato, Ozeki et al., ${ }^{(124)}$ utilizando desenho experimental com desenvolvimento de OA por ACLT, demonstraram ser insuficiente um único transplante celular $\left(1 \times 10^{6}\right.$ células/animal; $\approx 3,3-4 \times 10^{6}$ células $/ \mathrm{kg}$ ), duas semanas após a cirurgia, a fim de impedir a progressão da lesão. Porém, quando realizaram transplante semanal, conseguiram observar a redução progressiva da OA, após oito e 12 semanas, no entanto não em quatro semanas. Complementarmente, o transplante de exossomos produzidos por CTMs, quando administrado semanalmente, também é capaz de reduzir a progressão da lesão em modelo de DMM, independente da presença das células. ${ }^{(149)}$

Outra observação: reduziu-se a atrofia muscular do tibial anterior, após quatro semanas do IAt com CTMs. Considerando que o turnover do tecido muscular é maior do que o da CA e que o tibial anterior é o músculo mais afetado pelo procedimento de DMM, dentre os avaliados, possivelmente nesse, pequenas alterações sejam mais facilmente detectadas. Mesmo as células sendo administradas via IAt, alguns estudos encontraram CTMs na musculatura do membro com OA após transplante. ${ }^{(123,151)} \mathrm{Li}$ et al. ${ }^{(152)}$ demonstraram a redução da perda de injeção de força muscular, assim como a apoptose de células satélites do músculos óleo intramuscular, em modelo animal de atrofia muscular, por imobilização do membro Além dessa possível ação anti-apoptótica, bem como em humanos, o referido efeito antiinflamatório pode ter reduzido a dor articular, ${ }^{(153)}$ evitando o desuso e consequente atrofia do membro.

O mesmo não ocorreu com os grupos DMM+CTM-IVt. Entretanto, Shehata et al. ${ }^{(89)}$ observaram que, após paralização muscular por toxina botulínica, o grupo receptor do transplante de CTMs via IVt apresentou menor redução do volume muscular, por mecanismos anti-apoptóticos. A principal diferença desse estudo encontra-se no efeito da toxina, produz sinais de apoptose, sistemicamente, o que provavelmente, sinalizou e ativou a ação das CTMs. Apesar dos indícios de homing 
celular encontrados, a sinalização de OA ou atrofia muscular, gerada por DMM, provavelmente não seja o bastante para atrair células suficientes, além da menor viabilidade dessa, após transplante.

A melhora do equilíbrio muscular para os grupos SHAM+CTM, após 12 semanas, pode ser resultado, tanto da redução do perfil inflamatório, a longo prazo, quanto da recuperação do procedimento cirúrgico, tendo em vista o fato de não apresentar lesão e esta alteração ter ocorrido, exclusivamente, após 12 semanas.

Em comparação com o grupo DMM+PLACEBO-IAt, o DMM+CTMIAt também apresentou maior imunossupressão de citocinas inflamatórias, após uma semana. Embora a administração celular por IVt não tenha o mesmo potencial modulatório em uma semana, manteve os níveis de RANTES (CCL5) mais baixos do que o transplante placebo intravenoso, em quatro e doze semanas. Esse efeito pode estar relacionado com uma maior capacidade sistêmica de regulação de células $T$ $\mathrm{CD}^{+}$. O receptor $C-C$ chemokine receptor type 5(CCR5) - responsável por reconhecer CCL5 nestas células T, também reconhece CCL3 (MIP-1a). Dessa forma, especulamos a elevada produção de MIP-1a, após o IVt, de forma que possa ter sido responsável por tal regulação.

Comparando as vias de transplante dos grupos DMM+CTM, a única diferença presente ocorreu, em uma semana após o transplante, com maiores níveis de IL-1 $\beta$ ao grupo IVt. A expressão de IL-1 relação com o aumento sistêmico de citocinas e quimiocinas, ${ }^{(154)}$ não sendo necessariamente, uma resposta direta das CTMs, uma vez serem eliminadas do organismo, em curto período de tempo.

Apesar de serem da mesma família, a produção de IL-18 e IL-1 por condrócitos e sinoviócitos são parcialmente independentes. ${ }^{(155)}$

Os dados de lavado sinovial apontam para um efeito imunossupressor das CTMs via IAt, por intermédio da redução da expressão de IL-18, quando comparadas com o grupo DMM-PLACEBO-IAt. Em articulações osteoartríticas, a IL-18 tem um papel importante sobre condrócitos e sinoviócitos, estimulando a produção de INF-y, TNF- $\alpha$, metaloproteinases, ciclooxigenases (COX), ON e prostaglandinas, além de outras citocinas pró-inflamatórias, partícipes da degradação da cartilagem. ${ }^{(155-157)}$ Também, a presença de IL-18 já foi descrita em fluido sinovial, soro e CA, em pacientes com OA de joelho. ${ }^{(158)}$ Apesar, de os resultados de histologia demonstrarem que o modelo não produziu hiperplasia sinovial, considerando os dados 
de soro e lavado sinovial, a IL-18 parece ser um bom indicador para o tratamento celular neste modelo de OA.

\subsection{Limitações do trabalho}

Diante dos cuidados com a redução de variáveis de confusão entre condições experimentais, não nos foi possível randomizar todos os animais, devido ao número de grupos e diferentes tipos de transplante. Optamos, então, por normalizar e individualizar os dados, quando possível, semelhante ao caso dos dados de multiplex e peso muscular.

Devido ao processamento histológico, realizado para análise de Safranina-O, a qualidade dos cortes em lâminas silanizadas não permitiu que realizássemos imuno-histoquímica, de forma reprodutível. Por esse motivo, inviabilizouse analisar a expressão de colágeno entre grupos, assim como a detecção das células transplantadas por anticorpo anti-luciferase.

O modelo animal de DMM apresenta baixo perfil inflamatório, e o ensaio multiplex não foi capaz de detectar a concentração de todas as citocinas a todos os animais. Sendo assim, a oscilação do $\mathrm{N}$ amostral entre grupos e citocinas, mesmo com os critérios rígidos estabelecidos para processamento do sinal (MFI para pg/mL), pode ter, randomicamente, influenciado algumas análises.

Ao transplante intravenoso no modelo de DMM, o $\mathrm{N}$ amostral, em que encontramos sinais de homing por luminescência e citometria de imagem, limita uma conclusão mais enfática sobre o direcionamento dessas células, após transplante.

A ausência de grupos SHAM, sem tratamento celular, impede a total dissociação entre a ação das células e a ausência da desestabilização do menisco no procedimento cirúrgico. Também, como não realizamos grupos com transplantes seriados IAt e IVt, não podemos excluir a possibilidade da efetividade, destas vias no tratamento contínuo de CTMs ao OA, nesse modelo animal. 


\section{CONCLUSÕES}

1. O desenvolvimento de osteoartrose por desestabilização do menisco medial, nove semanas após o procedimento cirúrgico, confirmou ser um bom modelo pré-clínico, pois apresenta características semelhantes ao desenvolvimento da patologia em humanos;

2. Quanto ao uso de células-tronco mesenquimais, isoladas da medula óssea de animais isogênicos, nesse modelo animal com osteoartrose já instalada (nove semanas), um único transplante $\left(2 \times 10^{6}\right.$ células $\left./ \mathrm{kg}\right)$ não foi capaz de regenerar ou impedir a progressão do grau de lesão da cartilagem articular, independentemente da via utilizada;

3. As células-tronco mesenquimais, transplantadas por via intravenosa, demonstraram possuir regulação sistêmica, a longo prazo, de uma citocina inflamatória e baixa viabilidade. Também, com os dados obtidos, não foi possível confirmar a ação de homing destas células, neste modelo animal;

4. O transplante intra-articular apresentou maior potencial para o tratamento da osteoartrose, pois permite que as células fiquem viáveis por mais tempo no interior da articulação, proporciona maior efeito imunoregulatório, após uma semana, e reduz a atrofia muscular, por um curto período de tempo. 
6 ANEXOS

Anexo 1. Prontuário de acompanhamento animal

\begin{tabular}{|c|c|c|c|c|c|c|c|c|}
\hline \multicolumn{9}{|c|}{ ACOMPANHAMENTO OPERATÓRIO E PÓS OPERATÓRIO } \\
\hline \multicolumn{3}{|l|}{ Data: } & \multicolumn{3}{|c|}{ Hora de Início: } & \multicolumn{3}{|c|}{ Hora do Término: } \\
\hline \multicolumn{9}{|c|}{$\begin{array}{l}\text { Procedimento Cirúrgi } \\
\text { (Protocolos página 1) }\end{array}$} \\
\hline \multicolumn{9}{|c|}{ Código do Animal: } \\
\hline \multicolumn{4}{|c|}{ Anestesia } & \multicolumn{5}{|c|}{ (Protocolos página 1) } \\
\hline \multicolumn{9}{|c|}{ Peso do animal: } \\
\hline \multicolumn{9}{|c|}{ Tipo de anestesia usada: Isoflurano } \\
\hline \multicolumn{9}{|c|}{ Fluxo de ar (mL/min): } \\
\hline \multicolumn{9}{|c|}{ Monitorização da anestesia (anotar a cada 15 minutos) } \\
\hline \multicolumn{3}{|c|}{ Nível de anestesia } & Indução & Início & & & 15min & 20min \\
\hline \multicolumn{9}{|c|}{ Dose (\%) } \\
\hline \multicolumn{3}{|c|}{$\begin{array}{l}\text { Profundidade da anestesia } \\
\text { Boa(B)/ Muito leve(ML)/ Muito } \\
\text { profunda(MP) }\end{array}$} & & & & & & \\
\hline \multicolumn{3}{|c|}{$\begin{array}{l}\text { Frequência Respiratória } \\
\text { Estável(E)/ Muito Alta(MA)/ } \\
\text { Muito Baixa(MB) }\end{array}$} & & & & & & \\
\hline \multicolumn{3}{|c|}{$\begin{array}{l}\text { Mucosas/Orelhas } \\
\text { Rosa(R)// } \\
\text { Avermelhada(AV)/Azulada(AZ) }\end{array}$} & & & & & & \\
\hline \multicolumn{9}{|c|}{ Analgesia Pré e Pós-operatória } \\
\hline \multirow[t]{2}{*}{ Pré } & Data: & \multicolumn{2}{|c|}{ Hora: } & \multirow{2}{*}{\multicolumn{3}{|c|}{ Escore de dor: }} & \multicolumn{2}{|c|}{ Peso do Animal: } \\
\hline & Analgésico: & & & & & & & Volume: \\
\hline \multirow[t]{2}{*}{ Pós } & Data: & \multicolumn{2}{|l|}{ Hora: } & \multicolumn{3}{|c|}{ Escore de dor: } & \multicolumn{2}{|c|}{ Peso do Animal: } \\
\hline & Analgésico: & & & & Dos & & & Volume: \\
\hline \multirow[t]{2}{*}{ 24h } & Data: & \multicolumn{2}{|l|}{ Hora: } & Escore & dor: & & Peso do & animal: \\
\hline & Analgésico: & & & & Dos & & & Volume: \\
\hline 48h & Data: & Hora: & & Escore & dor: & & Peso do & animal: \\
\hline * & Analgésico: & & & & Dos & & & Volume: \\
\hline $72 \mathrm{~h}$ & Data: & Hora: & & Escore & dor: & & Peso do & animal: \\
\hline * & Analgésico: & & & & Dos & & & Volume: \\
\hline 96h & Data: & Hora: & & Escore & dor: & & Peso do & animal: \\
\hline * & Analgésico: & & & & Dos & & & Volume: \\
\hline 120 & Data: & Hora: & & Escore & dor: & & Peso do & animal: \\
\hline $\mathbf{h}^{\star}$ & Analgésico: & & & & Dos & & & Volume: \\
\hline 144 & Data: & Hora: & & Escore & dor: & & Peso do & animal: \\
\hline $\mathbf{h}^{*}$ & Analgésico: & & & & Dos & & & Volume: \\
\hline 168 & Data: & Hora: & & Escore & dor: & & Peso do & animal: \\
\hline $\mathbf{h}^{\star}$ & Analgésico: & & & & Dos & & & Volume: \\
\hline
\end{tabular}

\section{EUTANÁSIA}

\begin{tabular}{|c|c|c|}
\hline Data: & Hora de Início: & Hora do Término: \\
\hline \multicolumn{3}{|c|}{ Método de eutanásia: } \\
\hline \multicolumn{3}{|c|}{ Tipo de anestesia usada: } \\
\hline Número do Lacre: & & nal: \\
\hline
\end{tabular}


Registro de Manipulação / Intervenção

Obs.: Intercorrências ou informações relevantes estão descritas no caderno científico

\begin{tabular}{|c|c|c|c|}
\hline Data & Hora & Procedimento & Caderno/Página \\
\hline & & & \\
\hline & & & \\
\hline & & & \\
\hline & & & \\
\hline & & & \\
\hline & & & \\
\hline & & & \\
\hline & & & \\
\hline & & & \\
\hline & & & \\
\hline & & & \\
\hline & & & \\
\hline & & & \\
\hline & & & \\
\hline & & & \\
\hline & & & \\
\hline & & & \\
\hline & & & \\
\hline & & & \\
\hline & & & \\
\hline & & & \\
\hline & & & \\
\hline & & & \\
\hline & & & \\
\hline & & & \\
\hline & & & \\
\hline & & & \\
\hline & & & \\
\hline & & & \\
\hline & & & \\
\hline & & & \\
\hline & & & \\
\hline & & & \\
\hline & & & \\
\hline & & & \\
\hline & & & \\
\hline & & & \\
\hline & & & \\
\hline & & & \\
\hline & & & \\
\hline & & & \\
\hline & & & \\
\hline & & & \\
\hline
\end{tabular}




\section{Anexo 2. RotinaMatLab "triangulação.m" para processamento de dados da Marcha 2D}

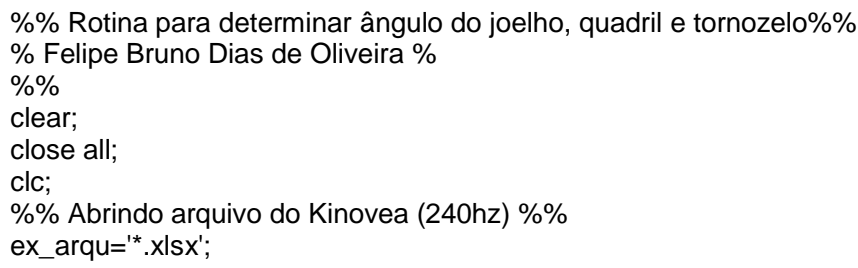

MT1= mat_comp1(:,1:2);ML1=mat_comp1(:,3:4);T1=mat_comp1 $(:, 5: 6) ; \mathrm{Cl} 1=$ mat_comp1 $(:, 7: 8)$; MT2= mat comp2(:,1:2);ML2=mat comp2(:,3:4);T2=mat comp2(:,5:6);Cl2=mat comp2(:,7:8); MT3=mat_comp3(:,1:2);ML3=mat_comp3(:,3:4);T3=mat_comp3(:,5:6);Cl3=mat_comp3(:,7:8); MT4= mat_comp4(:,1:2);ML4=mat_comp4(:,3:4);T4=mat_comp4(:,5:6);Cl4=mat_comp4(:,7:8); MT5=mat_comp5(:,1:2);ML5=mat_comp5(:,3:4);T5=mat_comp5(:,5:6);Cl5=mat_comp5(:,7:8); MT6= mat_comp6(:,1:2);ML6=mat_comp6(:,3:4);T6=mat_comp6(:,5:6);Cl6=mat_comp6(:,7:8); MT7= mat_comp7(:,1:2);ML7=mat_comp7(:,3:4);T7=mat_comp7(:,5:6);Cl7=mat_comp7(:,7:8); MT8=mat_comp8(:,1:2);ML8=mat_comp8(:,3:4);T8=mat_comp8(:,5:6);Cl8=mat_comp8(:,7:8); MT9= mat_comp9(:,1:2);ML9=mat_comp9(:,3:4);T9=mat_comp9(:,5:6);Cl9=mat_comp9(:,7:8); MT10= mat_comp10(:,1:2);ML10=mat_comp10(:,3:4);T10=mat_comp10(:,5:6);Cl10=mat_comp10(:,7:8);

tam_f(1:length $(x), 1)=$ input('Qual o tamanho do femur? '); tam_ti(1:length $(x), 1)=$ input('Qual o tamanho da tibia? ');

\% Fazendo matriz de tempo Condilo Lateral (CL) 1\% tamanho = length $\left(\mathrm{mat} \_c o m p 1\right) ; \quad$ inicio_ $\mathrm{x}=1 ;$ inicio_m $=1$; inicio_ang $=1$; inicio_m_ang $=1 ; \mathrm{CL} 1=$ zeros(tamanho,2); mat_ang_j1 = zeros $(\operatorname{tamanho}, \overline{1})$;

\% Equação da Triangulação 1\% 
whileinicio $\mathrm{x}<=$ tamanho

$[\operatorname{lnt} x 1, \operatorname{lnty} 1]$

circcirc(mat_comp1(inicio_x,5),mat_comp1(inicio_x,6),tam_f(inicio_x,1),mat_comp1(inicio_x,3),mat_comp1(inicio_x,4),tam_ti(inicio_ $\mathrm{x}, 1)$ );

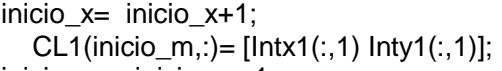

CLT1= CL1(inicio_ang,::)-T1 (inicio_ang,:);

CLML1= CL1 (inicio_ang,:)-ML1 (inicio_ang,:);

ang_j1 = atan2d(abs $(\operatorname{det}([\mathrm{CLT1} ; \mathrm{CLML1}]))$, dot $(\mathrm{CLT1}, \mathrm{CLML1}))$

inicio_ang = inicio_ang +1 ;

mat_ang_j1(inicio_m_ang,:) = ang_j1;

inicio_m_ang $=$ inicio_m_ang +1 ;

end

$\%$ Fazendo matriz de tempo do quadril $1 \%$

tamanho = length $($ mat_comp 1$)$; inicio_ang $=1$; inicio_m_ang $=1$; mat_ang_q1 $=$ zeros $($ tamanho, 1$)$;

$\%$ Equação de determinação do angulo do quadril por tangente $1 \%$

whileinicio ang $<=$ tamanho

TCl1= T1 (inicio ang,:)-Cl1 (inicio ang,:);

TCL1= T1 (inicio_ang,:)-CL1(inicio_ang,:);

ang_q1 = atan2 $\bar{d}(\operatorname{abs}(\operatorname{det}([\mathrm{TCl} 1 ; \mathrm{TC} L 1])), \operatorname{dot}(\mathrm{TCl} 1, \mathrm{TCL} 1))$;

inicio ang $=$ inicio ang +1 ;

mat_ang_q1 (inicio_m_ang,:) = ang_q1

inicio_m_ang $=$ inicio_m_ang +1 ;

end

$\%$ Fazendo matriz de tempo do tornozelo $1 \%$

tamanho = length $($ mat_comp 1$)$; inicio_ang $=1$; inicio_m_ang $=1$; mat_ang_to $1=$ zeros $($ tamanho, 1$)$;

$\%$ Equação de determinação do angulo do tornozelo por tangente $1 \%$

whileinicio_ang $<=$ tamanho

MLCL1= ML1(inicio ang,:)-CL1(inicio ang,:);

MLMT1= ML1 (inicio_ang,:)-MT1(inicio_ang,:);

ang_to1 $=$ atan2d(abs(det([MLCL1;MLMT1])), $\operatorname{dot}(\operatorname{MLCL} 1, \mathrm{MLMT1}))$

inicio_ang = inicio_ang +1 ;

mat_ang_to1(inicio_m_ang,:) = ang_to1;

inicio_m_ang = inicio_m_ang+1;

end

$\%$ Fazendo matriz de tempo Condilo Lateral (CL) $2 \%$

tamanho = length (mat comp2); inicio $\mathrm{x}=1 ;$ inicio $\mathrm{m}=1 ;$ inicio ang $=1 ;$ inicio $\mathrm{m}$ ang $=1 ; \mathrm{CL2}=$ zeros $($ tamanho,2);mat_ang_j2 $=$ zeros $($ tamanho, 1$)$;

$\%$ Equação da Triangulação 2\%

whileinicio_ $\mathrm{x}<=$ tamanho

[Intx2,Inty2]

circcirc(mat_comp2(inicio_x,5),mat_comp2(inicio_x,6),tam_f(inicio_x,1),mat_comp2(inicio_x,3),mat_comp2(inicio_x,4),tam_ti(inicio_ $\mathrm{x}, 1)$ );

inicio_ $x=$ inicio_ $x+1$

CL2(inicio_m,:)=[Intx2(:,1) Inty2(:,1)];

inicio $m=$ inicio $m+1$

end

whileinicio_ang $<=$ tamanho

CLT2= CL2(início ang,::-T2(inicio ang,:);

CLML2= CL2(início_ang,:)-ML2(inicio_ang,:);

ang $\_2$ = atan2d $(\operatorname{abs}(\operatorname{det}([C L T 2 ; C L M L 2])), \operatorname{dot}(C L T 2, C L M L 2))$

inicio ang $=$ incio ang +1

mat_ang_j2(inicio_m_ang,: $)=$ ang_j2;

inicio_m_ang $=$ inicio_m_ang +1

end

$\%$ Fazendo matriz de tempo do quadril $2 \%$

tamanho = length(mat_comp2); início_ang = 1 ; início_m_ang = 1 ; mat_ang_q2 = zeros $($ tamanho, 1$)$;

\% Equação de determinação do ângulo do quadril por tangente $2 \%$ 
whileinicio_ang $<=$ tamanho

$\mathrm{TCl} 2=\mathrm{T} 2$ (início ang,:) $-\mathrm{Cl} 2$ (inicio ang,:);

TCL2= T2 (início_ang,:)-CL2(inicio_ang,:);

ang_q2 = atan2d(abs(det([TCl2; TCL2])), $\operatorname{dot}(\mathrm{TCl} 2, \mathrm{TCL} 2))$;

inicio_ang = início_ang +1 ;

mat_ang_q2(inicio_m_ang,:) = ang_q2;

inicio_m_ang = início_m_ang+1;

end

$\%$ Fazendo matriz de tempo do tornozelo $2 \%$

tamanho = length (mat_comp2); início_ang = 1 ; início_m_ang = 1; mat_ang_to2 = zeros $(\operatorname{tamanho,1})$;

$\%$ Equação de determinação do angulo do tornozelo por tangente $2 \%$

whileinicio_ang $<=$ tamanho

MLCL2= ML2(início ang,:)-CL2(inicio ang,:);

MLMT2= ML2(início_ang,:)-MT2(inicio_ang,:);

ang_to2 $=\operatorname{atan2d}(\operatorname{abs}(\operatorname{det}([M L C L 2 ; M L M T 2])), \operatorname{dot}(M L C L 2, M L M T 2))$;

inicio_ang = início_ang +1 ;

mat_ang_to2(início_m_ang,:) = ang_to2;

inicio_m_ang = início_m_ang+1;

end

\% Fazendo matriz de tempo Condilo Lateral (CL) 3\%

tamanho = length (mat comp3); inicio $\mathrm{x}=1 ;$ inicio $\mathrm{m}=1 ;$ inicio ang $=1 ;$ inicio $\mathrm{m}$ ang $=1 ; \mathrm{CL} 3=$ zeros(tamanho,2);mat_ang_j3 = zeros(tamanho,1);

\% Equação da Triangulação 3\%

whileinicio_ $\mathrm{x}<=$ tamanho

[Intx3,Inty3]

circcirc(mat_comp3(inicio_x,5),mat_comp3(inicio_x,6),tam_f(início_x,1),mat_comp3(inicio_x,3),mat_comp3(inicio_x,4),tam_ti(incio_ $\mathrm{x}, 1)$ );

inicio_ $x=$ início_ $x+1$

CL3(inicio_m,: $)=[\operatorname{lnt} x 3(:, 1) \operatorname{lnty} 3(:, 1)]$;

inicio $\mathrm{m}=$ iniício $\mathrm{m}+1$;

end

whileinicio_ang $<=$ tamanho

CLT3= CL3(início ang,:)-T3(inicio ang,:);

CLML3= CL3(início_ang,:)-ML3(inicio_ang,:);

ang $\mathrm{j} 3=\operatorname{atan} 2 \mathrm{~d}(\operatorname{abs}(\operatorname{det}([\mathrm{CLT3} ; \operatorname{CLML3]}))$, dot $(\mathrm{CLT} 3, \mathrm{CLML3}))$

inicio_ang = início_ang +1 ;

mat_ang_j3(início_m_ang,:) = ang_j3;

inicio $m$ ang $=$ início $m$ _ang +1 ;

end

$\%$ Fazendo matriz de tempo do quadril 3\%

tamanho = length (mat_comp3); início_ang $=1$; início_m_ang = 1 ; mat_ang_q3 = zeros $(\operatorname{tamanho}, 1)$;

\% Equação de determinação do ângulo do quadril por tangente 3\%

whileinicio_ang $<=$ tamanho

$\mathrm{TCl} 3=\mathrm{T} 3$ (início ang,:)- $\mathrm{Cl} 3$ (inicio ang,:);

TCL3= T3(início_ang,:)-CL3(inicio_ang,:);

ang_q3 $=\operatorname{atan} 2 \overline{\mathrm{d}}(\operatorname{abs}(\operatorname{det}([\mathrm{TCl} 3 ; \mathrm{TC} \mathrm{C} 3])), \operatorname{dot}(\mathrm{TCl} 3, \mathrm{TCL} 3))$;

inicio_ang = início_ang +1 ;

mat_ang_q3(início_m_ang,:) = ang_q3;

inicio $m$ ang $=$ início $m$ ang +1 ;

end

$\%$ Fazendo matriz de tempo do tornozelo $3 \%$

tamanho = length (mat_comp3); inicio_ang $=1$; inicio_m_ang $=1$; mat_ang_to3 $=$ zeros $($ tamanho, 1 );

\% Equação de determinação do ângulo do tornozelo por tangente 3\%

whileinicio_ang $<=$ tamanho

MLCL3= ML3(início_ang,:)-CL3(inicio_ang,:);

MLMT3= ML3(início ang,:)-MT3(inicio ang,:);

ang_to3 $=$ atan2d(abs(det([MLCL3;MLMT3])), $\operatorname{dot}($ MLCL3,MLMT3))

inicio_ang = início_ang +1 ;

mat_ang_to3(início_m_ang,:) = ang_to3;

inicio_m_ang = início_m_ang+1;

end

\% Fazendo matriz de tempo Condilo Lateral (CL) 4\% 
tamanho = length(mat_comp4); início_x $=1 ;$ início_m $=1 ;$ início_ang $=1 ;$ início_m_ang = $1 ; \mathrm{CL4}=$ zeros(tamanho,2);mat_ang_j4 = zeros(tamanho,1);

\% Equação da Triangulação \%

whileinicio_ $x<=$ tamanho

[Intx4,Inty4]

circcirc(mat_comp4(inicio_x,5),mat_comp4(inicio_x,6),tam_f(inicio_x,1),mat_comp4(inicio_x,3),mat_comp4(inicio_x,4),tam_ti(inicio_ $\mathrm{x}, 1)$ );

inicio_x= início_ $x+1$

CL4 4 (inicio_m,: $)=[\operatorname{lnt} x 4(:, 1) \operatorname{lnty} 4(:, 1)]$;

inicio_m = início_m+1;

end

whileinicio_ang $<=$ tamanho

CLT4= CL4(inicio ang,:)-T4(inicio ang,:);

CLML4= CL4(inicio_ang,:)-ML4(inicio_ang,:);

ang $\_44=\operatorname{atan} 2 \mathrm{~d}(\operatorname{abs}(\operatorname{det}([C L T 4 ; C L M L 4]))$, $\operatorname{dot}(C L T 4, C L M L 4))$;

inicio_ang = início_ang+1;

mat_ang_j4(início_m_ang,:) = ang_j4;

inicio_m_ang = início_m_ang+1;

end

$\%$ Fazendo matriz de tempo do quadril $4 \%$

tamanho = length (mat_comp4); início_ang $=1$; inicio_m_ang = 1 ; mat_ang_q4 = zeros (tamanho, 1 );

\% Equação de determinação do ângulo do quadril por tangente $4 \%$

whileinicio_ang $<=$ tamanho

TCl4= T4(início_ang,:)-Cl4(início_ang,:);

TCL4= T4(início_ang,:)-CL4(início_ang,:);

ang $\mathrm{q} 4=\operatorname{atan} 2 \mathrm{~d}(\operatorname{abs}(\operatorname{det}([\mathrm{TCl} 4 ; \mathrm{TCL} 4]))$, $\operatorname{dot}(\mathrm{TCl} 4, \mathrm{TCL} 4))$;

inicio_ang = início_ang +1 ;

mat_ang_q4(inicio_m_ang,:) = ang_q4;

inicio_m_ang = início_m_ang+1;

end

$\%$ Fazendo matriz de tempo do tornozelo $4 \%$

tamanho = length(mat_comp4); inicio_ang $=1$; inicio_m_ang $=1$; mat_ang_to $4=$ zeros $($ tamanho, 1$)$;

\% Equação de determinação do angulo do tornozelo por tangente 4\%

whileinicio_ang $<=$ tamanho

MLCL4= ML4(início_ang,:)-CL4(inicio_ang,:);

MLMT4= ML4(início_ang,:)-MT4(inicio_ang,:);

ang_to $4=\operatorname{atan} 2 \mathrm{~d}(\operatorname{abs}(\operatorname{det}([M L C L 4 ; M L M T 4])), \operatorname{dot}(M L C L 4, M L M T 4))$;

inicio_ang = início_ang +1 ;

mat ang to4(início $m$ ang,:) = ang to 4 ;

inicio_m_ang = início_m_ang +1 ;

end

$\%$ Fazendo matriz de tempo Condilo Lateral (CL) $5 \%$

tamanho = length (mat_comp5); inicio_x $\mathrm{x}=1 ;$ inicio_m $=1$; início_ang = 1; inicio_m_ang = $1 ; \mathrm{CL5}=$ zeros(tamanho,2); mat_ang_j5 = zeros(tamanho, 1 );

\% Equação da Triangulação 5\%

whileinicio_ $x<=$ tamanho

[Intx5,Inty5]

circcirc(mat_comp5(inicio_x,5),mat_comp5(inicio_x,6),tam_f(inicio_x,1),mat_comp5(inicio_x,3),mat_comp5(inicio_x,4),tam_ti(inicio_ $\mathrm{x}, 1)$ );

inicio $x=$ inicio_ $x+1$;

CL5(inicio $m,:)=[\operatorname{lnt} x 5(:, 1) \operatorname{lnty5}(:, 1)]$;

inicio_m $=$ inicio_ $m+1$.

end

whileinicio_ang $<=$ tamanho

CLT5= CL5(inicio_ang,::)-T5(inicio_ang,:);

CLML5= CL5(inicio_ang,:)-ML5(inicio_ang,:);

ang $j 5=$ atan2d(abs(det([CLT5;CLML5])), $\operatorname{dot}(C L T 5, C L M L 5))$;

inicio_ang = inicio_ang +1 ;

mat ang $j 5$ (inicio $m$ ang, $:$ ) $=$ ang $j 5$;

inicio_m_ang $=$ inicio_m_ang +1 ;

end

$\%$ Fazendo matriz de tempo do quadril 5\%

tamanho = length(mat_comp5); inicio_ang $=1$; inicio_m_ang $=1$; mat_ang_q5 = zeros $(\operatorname{tamanho}, 1)$; 
\% Equação de determinação do angulo do quadril por tangente 5\% whileinicio_ang $<=$ tamanho

TCI5= T5(inicio_ang,:)-Cl5(inicio_ang,:);

TCL5= T5(inicio_ang,:)-CL5(inicio_ang,:);

ang_q5 = atan2d(abs(det([TCl5;TCL5])),dot(TCl5,TCL5));

inicio_ang = inicio_ang +1 ;

mat_ang_q5(inicio_m_ang,:) = ang_q5;

inicio_m_ang = inicio_m_ang+1;

end

$\%$ Fazendo matriz de tempo do tornozelo $5 \%$

tamanho = length $($ mat_comp5); inicio_ang $=1$; inicio_m_ang $=1$; mat_ang_to5 = zeros $(\operatorname{tamanho}, 1)$;

$\%$ Equação de determinação do angulo do tornozelo por tangente 5\%

whileinicio_ang $<=$ tamanho

MLCL5= ML5(inicio_ang,::)-CL5(inicio_ang,::);

MLMT5= ML5(inicio_ang,:)-MT5(inicio_ang,:);

ang_to5 = atan2d(abs(det([MLCL5;MLMT5])), dot(MLCL5,MLMT5));

inicio_ang = inicio_ang +1 ;

mat_ang_to5(inicio_m_ang,:) = ang_to5;

inicio_m_ang $=$ inicio_m_ang +1 ;

end

$\%$ Fazendo matriz de tempo Condilo Lateral (CL) $6 \%$

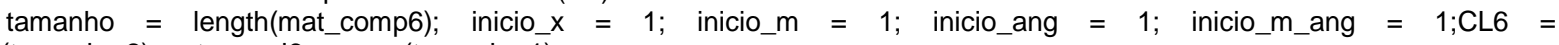
zeros(tamanho,2);mat_ang_j6 $=$ zeros(tamanho, 1 )

\% Equação da Triangulação 6\%

whileinicio_ $x<=$ tamanho

$[\ln x 6, \ln t y 6]$

circcirc(mat_comp6(inicio_x,5),mat_comp6(inicio_x,6),tam_f(inicio_x,1),mat_comp6(inicio_x,3),mat_comp6(inicio_x,4),tam_ti(inicio_ $\mathrm{x}, 1)$ );

inicio_ $x=$ inicio_ $x+1$

CL6 (inicio $m,:)=[\operatorname{lnt} x 6(:, 1) \operatorname{lnty} 6(:, 1)]$;

inicio_m $=$ inicio_m +1 ;

end

whileinicio_ang $<=$ tamanho

CLT6= CL6(inicio_ang,::)-T6(inicio_ang,:);

CLML6= CL6(inicio ang,:)-ML6(inicio ang,:);

ang_j6 = atan2d(abs(det ([CLT6;CLML6])), dot(CLT6,CLML6));

inicio_ang = inicio_ang +1 ;

mat ang_j6(inicio_m_ang,:) = ang_j6

inicio_m_ang = inicio_m_ang+1;

end

$\%$ Fazendo matriz de tempo do quadril $6 \%$

tamanho $=$ length $($ mat comp6); inicio ang $=1$; inicio $m$ ang $=1$; mat ang $q 6=$ zeros $($ tamanho 1$)$;

$\%$ Equação de determinação do angulo do quadril por tangente $6 \%$

whileinicio_ang $<=$ tamanho

TCI6= T6(inicio_ang,:)-Cl6(inicio_ang,:);

TCL6= T6 (inicio ang,:)-CL6(inicio ang,:);

ang_q6 = atan2 $\overline{\mathrm{d}}(\operatorname{abs}(\operatorname{det}([\mathrm{TCl} 6 ; \mathrm{TCL} 6]))$, $\operatorname{dot}(\mathrm{TCl} 6, \mathrm{TCL} 6))$;

inicio_ang $=$ inicio_ang +1 ;

mat_ang_q6(inicio_m_ang,:) = ang_q6;

inicio_m_ang = inicio_m_ang +1 ;

end

$\%$ Fazendo matriz de tempo do tornozelo $6 \%$

tamanho = length $($ mat_comp6); inicio_ang $=1$; inicio_m_ang $=1$; mat_ang_to6 $=$ zeros $($ tamanho 1$)$;

\% Equação de determinação do angulo do tornozelo por tangente 6\%

whileinicio_ang $<=$ tamanho

MLCL6= ML6(inicio_ang,:)-CL6(inicio_ang,:);

MLMT6= ML6(inicio ang,:)-MT6(inicio ang,:);

ang_to $=$ atan2d(abs(det([MLCL6;MLMT6])), $\operatorname{dot}($ MLCL6,MLMT6));

inicio_ang = inicio_ang +1

mat_ang_to6(inicio_m_ang,:) = ang_to6;

inicio_m_ang $=$ inicio_m_ang +1 ;

end 
\% Fazendo matriz de tempo Condilo Lateral (CL) $7 \%$

tamanho = length $\left(\mathrm{mat} \_c o m p 7\right) ; \quad$ inicio_ $\mathrm{x}=1 ;$ inicio_m $=1 ;$ inicio_ang = 1 ; inicio_m_ang $=1 ; \mathrm{CL7}=$ zeros(tamanho,2);mat_ang_j $7=$ zeros(tamanho,1);

\% Equação da Triangulação 7\%

whileinicio_ $\mathrm{x}<=$ tamanho

$[\operatorname{lnt} x 7, \operatorname{Inty} 7]$

circcirc(mat_comp7(inicio_x,5),mat_comp7(inicio_x,6),tam_f(inicio_x,1),mat_comp7(inicio_x,3),mat_comp7(inicio_x,4),tam_ti(inicio $\mathrm{x}, 1))$;

inicio $x=$ inicio $x+1$

CL7 (inicio $m,:)=[\operatorname{Int} x 7(:, 1) \operatorname{Inty} 7(:, 1)]$;

inicio_m $=$ inicio_m +1 ;

end

whileinicio_ang $<=$ tamanho

CLT7= CL7(inicio_ang,::)-T7(inicio_ang,:);

CLML7= CL7(inicio_ang,:)-ML7(inicio_ang,:);

ang_j7 = atan2d(abs(det([CLT7; CLML7])), dot(CLT7,CLML7));

inicio_ang $=$ inicio_ang +1 ;

mat ang $j 7$ (inicio $m$ ang, : $)=$ ang $j 7$

inicio_m_ang = inicio_m_ang +1 ;

end

$\%$ Fazendo matriz de tempo do quadril $7 \%$

tamanho = length $($ mat_comp7); inicio_ang $=1$; inicio_m_ang = 1 ; mat_ang_q7 = zeros $($ tamanho, 1$)$;

$\%$ Equação de determinação do angulo do quadril por tangente $7 \%$

whileinicio_ang $<=$ tamanho

$\mathrm{TCl} 7=\mathrm{T} 7$ (inicio_ang,:)-Cl7(inicio_ang,:);

$\mathrm{TCL} 7=\mathrm{T} 7$ (inicio ang,:)-CL7(inicio ang.:);

ang_q7 = atan2 $\overline{\mathrm{d}}(\operatorname{abs}(\operatorname{det}([\mathrm{TCl} / \mathrm{T} \overline{\mathrm{C} L 7]})), \operatorname{dot}(\mathrm{TCl} 7, \mathrm{TCL} 7))$;

inicio_ang = inicio_ang +1 ;

mat_ang_q7(inicio_m_ang,:) = ang_q7;

inicio_m_ang = inicio_m_ang +1 ;

end

$\%$ Fazendo matriz de tempo do tornozelo $7 \%$

tamanho $=$ length $($ mat_comp7); inicio_ang $=1$; inicio_m_ang $=1$; mat_ang_to7 $=$ zeros $(\operatorname{tamanho}, 1)$;

$\%$ Equação de determinação do angulo do tornozelo por tangente $7 \%$

whileinicio ang $<=$ tamanho

MLCL7= ML7(inicio_ang,:)-CL7(inicio_ang,:);

MLMT7= ML7(inicio_ang,:)-MT7(inicio_ang,:);

ang_to7 $=$ atan2d(abs(det ([MLCL7;MLMT7])), dot(MLCL7,MLMT7))

inicio ang $=$ inicio ang +1 ;

mat_ang_to7(inicio_m_ang,:) = ang_to7;

inicio_m_ang $=$ inicio_m_ang +1 ;

end

\% Fazendo matriz de tempo Condilo Lateral (CL)8\%

tamanho $=$ length $\left(m a t \_c o m p 8\right) ; \quad$ inicio_ $\mathrm{x}=1 ;$ inicio_m $=1 ;$ inicio_ang $=1 ;$ inicio_m_ang $=1 ; \mathrm{CL} 8=$ zeros(tamanho,2);mat ang j8 $8=$ zeros(tamanho, 1 );

\% Equação da Triangulação 8\%

whileinicio $\mathrm{x}<=$ tamanho

[Intx8,Inty8]

circcirc(mat_comp8(inicio_x,5),mat_comp8(inicio_x,6),tam_f(inicio_x,1),mat_comp8(inicio_x,3),mat_comp8(inicio_x,4),tam_ti(inicio $\mathrm{x}, 1)$ );

inicio $x=$ inicio $x+1$

CL8 $($ inicio_m,: $)=[\operatorname{lnt} x 8(:, 1) \operatorname{Inty} 8(:, 1)]$

inicio_m = inicio_m+1;

end

whileinicio ang $<=$ tamanho

CLT8= CL8(inicio_ang,:)-T8(inicio_ang,:);

CLML8= CL8(inicio ang.:)-ML8(inicio ang,:);

ang $\_8=\operatorname{atan2d}(\operatorname{abs}(\operatorname{det}([C L T 8 ; C L M L 8])), \operatorname{dot}(C L T 8, C L M L 8))$;

inicio ang $=$ inicio ang +1 ;

mat_ang_j8(inicio_m_ang,:) $=$ ang_j8

inicio_m_ang $=$ inicio_m_ang +1 ;

end

$\%$ Fazendo matriz de tempo do quadril 8\% 
tamanho $=$ length $($ mat_comp8); inicio_ang $=1$; inicio_m_ang $=1$; mat_ang_q8 $=$ zeros $($ tamanho, 1$)$; \% Equação de determinação do angulo do quadril por tangente $8 \%$ whileinicio_ang $<=$ tamanho

TCl8= T8(inicio_ang,:)-Cl8(inicio_ang,:);

TCL8= T8(inicio ang,:)-CL8(inicio ang,:);

ang_q8 = atan2 $\mathrm{d}(\operatorname{abs}(\operatorname{det}([\mathrm{TCl} 8 ; \mathrm{TC} L \mathrm{C}]))$, $\operatorname{dot}(\mathrm{TCl} 8, \mathrm{TCL} 8))$;

inicio ang = inicio ang +1 ;

mat_ang_q8(inicio_m_ang,:) = ang_q8;

inicio_m_ang $=$ inicio_m_ang +1 ;

end

$\%$ Fazendo matriz de tempo do tornozelo 8\%

tamanho $=$ length $($ mat_comp8); inicio_ang $=1$; inicio_m_ang $=1$; mat_ang_to8 $=$ zeros $(\operatorname{tamanho}, 1)$;

\% Equação de determinação do angulo do tornozelo por tangente $8 \%$

whileinicio ang $<=$ tamanho

MLCL8= ML8(inicio ang,:)-CL8(inicio ang,:);

MLMT8= ML8(inicio_ang,:)-MT8(inicio_ang,:);

ang_to8 = atan2d(abs(det([MLCL8;MLMT8])), $\operatorname{dot}($ MLCL8,MLMT8));

inicio ang $=$ inicio ang +1

mat_ang_to8(inicio_m_ang,:) = ang_to8;

inicio_m_ang = inicio_m_ang+1;

end

\% Fazendo matriz de tempo Condilo Lateral (CL) $9 \%$

tamanho = length $\left(m a t \_c o m p 9\right) ; \quad$ inicio_ $\mathrm{x}=1 ;$ inicio_m $=1 ;$ inicio_ang $=1 ;$ inicio_m_ang $=1 ; \mathrm{CL9}=$ zeros(tamanho,2);mat_ang_j9 = zeros(tamanho,1);

$\%$ Equação da Triangulação $9 \%$

whileinicio $\mathrm{x}<=$ tamanho

$[\operatorname{lnt} x 9, \operatorname{lnty} 9]$

circcirc(mat comp9(inicio $\times$,5), mat comp9(inicio $x, 6$ ),tam f(inicio $x, 1$ ), mat comp9(inicio $\times$,3),mat comp9(inicio $\times$,4), tam ti(inicio $\mathrm{x}, 1)$ );

inicio $x=$ inicio $x+1$

CL9 $($ inicio_m,: $)=[\operatorname{lnt} x 9(:, 1) \operatorname{lnty} 9(:, 1)]$;

inicio_m = inicio_m+1;

end

whileinicio ang $<=$ tamanho

CLT9= CL9(inicio ang,:)-T9(inicio ang,:);

CLML9= CL9(inicio ang,:)-ML9(inicio ang,:);

ang $\_9$ = atan2d(abs (det([CLT9;CLML9])), $\left.\operatorname{dot}(\operatorname{CLT} 9, \operatorname{CLML9})\right)$;

inicio ang $=$ inicio ang +1 ;

mat_ang_j9(inicio_m_ang,:) = ang_j9;

inicio $m$ ang $=$ inicio $m$ ang +1 ;

end

$\%$ Fazendo matriz de tempo do quadril $9 \%$

tamanho = length (mat_comp9); inicio_ang $=1$; inicio_m_ang $=1$; mat_ang_q9 $=$ zeros $($ tamanho, 1$)$;

$\%$ Equação de determinação do angulo do quadril por tangente $9 \%$

whileinicio ang $<=$ tamanho

TCI9= T9(inicio ang,:)-Cl9(inicio_ang,:);

TCL9= T9(inicio_ang,:)-CL9(inicio_ang,:);

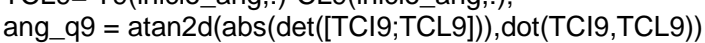

inicio_ang $=$ inicio_ang +1 .

mat_ang_q9(inicio_m_ang,:) = ang_q9;

inicio_m_ang $=$ inicio_m_ang +1

end

$\%$ Fazendo matriz de tempo do tornozelo 9\%

tamanho = length (mat_comp9); inicio_ang $=1$; inicio_m_ang $=1$; mat_ang_to9 $=$ zeros $($ tamanho, 1$)$;

$\%$ Equação de determinação do angulo do tornozelo por tangente $9 \%$

whileinicio_ang $<=$ tamanho

MLCL9= ML9(inicio ang,:)-CL9(inicio ang,:);

MLMT9= ML9(inicio_ang,:)-MT9(inicio_ang,:);

ang to9 $=$ atan2d(abs (det([MLCL9;MLMT9])), $\operatorname{dot}($ MLCL9,MLMT9))

inicio_ang = inicio_ang +1 ;

mat ang to9(inicio $m$ ang,:) = ang to 9

inicio $m$ ang $=$ inicio $m$ ang +1

end 
$\%$ Fazendo matriz de tempo Condilo Lateral $(\mathrm{CL}) 10 \%$

tamanho $=$ length $\left(\mathrm{mat} \_c o m p 10\right) ;$ inicio_x $=1 ;$ inicio_m $=1 ;$ inicio_ang $=1$; inicio_m_ang $=1 ; \mathrm{CL} 10=$ zeros $($ tamanho,2);mat_ang_j10 = zeros $($ tamanho, 1$)$;

$\%$ Equação da Triangulação 10\%

whileinicio_ $x<=$ tamanho

$[\operatorname{lnt} x 10, \operatorname{Inty} 10]$

circcirc(mat_comp10(inicio_x,5),mat_comp10(inicio_x,6),tam_f(inicio_x,1),mat_comp10(inicio_x,3),mat_comp10(inicio_x,4),tam_ti(i nicio_x,1));

inicio $x=$ inicio $x+1$

CL10(inicio_m,$:)=[\operatorname{lnt} x 10(:, 1) \operatorname{lnty} 10(:, 1)]$;

inicio_m = inicio_m+1;

end

whileinicio_ang $<=$ tamanho

CLT10 $=$ CL10(inicio_ang,:)-T10(inicio_ang,:);

CLML10= CL10 (inicio_ang,:)-ML10(inicio_ang,:);

ang $\_10=\operatorname{atan} 2 \mathrm{~d}(\operatorname{abs}(\operatorname{det}([\mathrm{CLT10}$; CLML10])), $\operatorname{dot}(\mathrm{CLT10}, \mathrm{CLML10}))$;

inicio ang $=$ inicio ang +1 ;

mat_ang_j10(inicio_m_ang,:) = ang_j10;

inicio_m_ang = inicio_m_ang +1 ;

end

$\%$ Fazendo matriz de tempo do quadril $10 \%$

tamanho $=$ length $($ mat_comp 10$) ;$ inicio_ang $=1$; inicio_m_ang $=1 ;$ mat_ang_q10 $=$ zeros $(\operatorname{tamanho}, 1)$;

$\%$ Equação de determinação do angulo do quadril por tangente $10 \%$

whileinicio_ang $<=$ tamanho

$\mathrm{TCl} 10=\mathrm{T} 10$ (inicio ang,:)-Cl10(inicio ang,:);

TCL10= T10(inicio_ang,::-CL10(inicio_ang,:);

ang_q10 = atan2d(abs(det([TCl10;TCL10])), $\operatorname{dot}(\mathrm{TCl} 10, \mathrm{TCL} 10))$;

inicio_ang $=$ inicio_ang +1 ;

mat_ang_q10(inicio_m_ang,:) = ang_q10;

inicio_m_ang $=$ inicio_m_ang +1 ;

end

$\%$ Fazendo matriz de tempo do tornozelo $10 \%$

tamanho = length (mat_comp10); inicio_ang $=1$; inicio_m_ang $=1$; mat_ang_to $10=z e r o s(\operatorname{tamanho}, 1)$; \% Equação de determinação do angulo do tornozelo por tangente 10\%

whileinicio_ang $<=$ tamanho

MLCL10=ML10(inicio_ang,:)-CL10(inicio_ang,:);

MLMT10= ML10(inicio_ang,:)-MT10(inicio_ang,:);

ang to10 $=\operatorname{atan2d}(\operatorname{abs}(\operatorname{det}([M L C L 10 ; M L M T 10])), \operatorname{dot}(M L C L 10, M L M T 10))$;

inicio_ang = inicio_ang +1 ;

mat_ang_to10(inicio_m_ang,:) = ang_to10;

inicio_m_ang = inicio_m_ang +1 ;

end

$\%$ Fazendo matriz de tempo joelho\%

mat_temp j1 $1=(0: 1: \text { length (mat_ang_j1) }-1)^{\prime *} 4.167$

mat_temp $\mathrm{j} 2=(0: 1 \text { :length (mat_ang_j2)-1 })^{\prime *} 4.167$

mat_temp $j 3=(0: 1$ :length (mat_ang_j 3$)-1)^{\prime * 4} 4.167$

mat_temp $j 4=(0: 1: \text { length (mat_ang_j4)-1 } 1)^{\prime *} 4.167$

mat temp $\mathrm{j} 5=(0: 1$ :length (mat ang $\mathrm{j} 5)-1)^{\prime *} 4.167$

mat_temp_j $6=(0: 1: \text { length (mat_ang_j6)-1) } 1)^{\prime *} 4.167$;

mat temp $j 7=(0: 1$ :length (mat ang $j 7)-1)^{\prime *} 4.167$

mat_temp_j $8=(0: 1 \text { :length (mat_ang_j8) }-1)^{\prime *} 4.167$

mat_temp $j 9=(0: 1: \text { length (mat_ang_j9)-1 })^{\prime * 4} 4.167$

mat temp $j 10=(0: 1 \text { :length(mat ang j10)-1 })^{\prime * 4} 4.167$;

$\%$ Fazendo matriz de tempo quadril\%

mat_temp_q1 $=(0: 1: \text { length (mat_ang_q1) }-1)^{\prime *} 4.167$;

mat_temp_q2 $=(0: 1: \text { length }(\text { mat_ang_q2 })-1)^{* *} 4.167 ;$

mat temp_q3 $=(0: 1 \text { :length (mat_ang_q3)-1 })^{\prime *} 4.167$;

mat_temp_q4 $=(0: 1: \text { length (mat_ang_q4) }-1)^{\prime *} 4.167$;

mat temp_q5 $=(0: 1 \text { :length (mat_ang_q5)-1 } 1)^{\prime *} 4.167 ;$

mat_temp_q6 $=(0: 1: \text { length (mat_ang_q6) }-1)^{\prime *} 4.167$;

mat_temp_q7 $=(0: 1:$ length (mat_ang_q7 $)-1)^{\prime *} 4.167$;

mat_temp_q8 $=(0: 1: \text { length (mat_ang_q8)-1 })^{\prime *} 4.167$;

mat_temp_q9 $=(0: 1: \text { length (mat_ang_q9) }-1)^{\prime *} 4.167$;

mat_temp_q10 $=(0: 1: \text { length (mat_ang_q10)-1 })^{\prime *} 4.167$; 
$\%$ Fazendo matriz de tempo tornozelo\%

mat temp to $1=(0: 1: \text { length }(\text { mat ang to } 1)-1)^{\prime * 4} 4.167$

mat_temp_to $2=(0: 1:$ length (mat_ang_to2 $)-1)^{\prime * 4} 4.167$;

mat_temp_to $3=(0: 1: \text { length (mat_ang_to3) }-1)^{\prime *} 4.167$;

mat_temp_to $4=(0: 1$ :length(mat_ang_to 4$)-1)^{\prime *} 4.167$;

mat_temp_to $5=(0: 1: \text { length (mat_ang_to5) }-1)^{\prime *} 4.167 ;$

mat_temp_to $6=(0: 1: \text { length }(\text { mat_ang_to6 })-1)^{\prime * 4} 4.167 ;$

mat_temp_to $7=(0: 1 \text { :length (mat_ang_to7) }-1)^{\prime *} 4.167$;

mat_temp_to $8=(0: 1:$ length (mat_ang_to 8$)-1)^{\prime * 4} 4.167 ;$

mat temp to $9=(0: 1: \text { length (mat_ang_to9) }-1)^{\prime *} 4.167 ;$

mat_temp_to $10=(0: 1:$ length (mat_ang_to 10$)-1)^{\prime *} 4.167 ;$

$\%$ Fazendo matriz de tempo normalizada joelho\%

mat_temp_j_n1 $=\left(\right.$ mat_temp_j1 $\left.1(:,:)^{*} 100\right) /$ mat_temp_j1 (end,:); mat_temp_j_n2 $=($ mat_temp_j2(:,:)*100)/mat_temp_j2(end,::); mat_temp_j_n3 $\left.=(\text { mat_temp_j3(:,:) })^{*} 100\right) /$ mat_temp_j3(end,:); mat_temp_j_n4 $=\left(\right.$ mat_temp_j4 $\left.4(:,:)^{*} 100\right) /$ mat_temp_j4(end,:); mat_temp_j_n5 $=($ mat_temp_j5(:,:)*100)/mat_temp_j5(end,:); mat_temp_j_n6 $=\left(\right.$ mat_temp_j6 $\left.(:,:)^{*} 100\right) /$ mat_temp_j6(end,:); mat_temp_j_n7 $=$ (mat_temp_j7(:,:)*100)/mat_temp_j7(end,:); mat_temp_j_n8 $\left.=(\text { mat_temp_j8(:,:) })^{*} 100\right) /$ mat_temp_j8(end,:); mat_temp_j_n9 $=\left(\right.$ mat_temp_j $\left.9(:,:)^{*} 100\right) /$ mat_temp_j9(end,:); mat_temp_j_n10 $=($ mat_temp_j10(:,:)*100)/mat_temp_j10(end,:);

$\%$ Fazendo matriz de tempo normalizada quadril\% mat_temp_q_n1 $=\left(\right.$ mat_temp_q1 $\left.(:,:)^{*} 100\right) /$ mat_temp_q1 $($ end,::); mat_temp_q_n2 $=\left(\right.$ mat_temp_q2 $\left.(:,:)^{*} 100\right) /$ mat_temp_q2(end,:); mat_temp_q_n3 $=\left(\right.$ mat_temp_q3 $\left.(:,:)^{*} 100\right) /$ mat_temp_q3(end,:); mat_temp_q_n4 $=\left(\right.$ mat_temp_q4 $\left.(:,:)^{*} 100\right) /$ mat_temp_q4(end,:); mat_temp_q_n5 $=\left(\right.$ mat_temp_q5 $\left.(:,:)^{*} 100\right) /$ mat_temp_q5(end,:); mat_temp_q_n6 $=($ mat_temp_q6(:,:)*100)/mat_temp_q6(end,:); mat_temp_q_n7 $=\left(\right.$ mat_temp_q7 $\left.(:,:)^{*} 100\right) /$ mat_temp_q7(end,:); mat_temp_q_n8 $=$ (mat_temp_q8(:,:)*100)/mat_temp_q8(end,:); mat_temp_q_n9 $\left.=(\text { mat_temp_q9(:,:) })^{*} 100\right) /$ mat_temp_q9(end,:); mat_temp_q_n10 $=\left(\right.$ mat_temp_q10(:::: $\left.{ }^{\star} 100\right) /$ mat_temp_q10(end,::);

\% Fazendo matriz de tempo normalizada tornozelo\% mat_temp_to_n1 $=\left(\right.$ mat_temp_to $\left.1(:,:)^{*} 100\right) /$ mat_temp_to 1 (end,::) mat_temp_to_n2 $=\left(\right.$ mat_temp_to2 $\left.(:,:)^{*} 100\right) /$ mat_temp_to2(end,:); mat temp to $n 3=$ (mat temp to3(::: $\left.)^{*} 100\right) /$ mat temp to3(end,:) mat_temp_to_n4 $=$ (mat_temp_to $\left.4(:,:)^{*} 100\right) /$ mat_temp_to $4($ end,$:) ;$ mat_temp_to_n5 $=$ (mat_temp_to5(:::: $\left.{ }^{*} 100\right) /$ mat_temp_to5(end,::) mat_temp_to_n6 $=$ (mat_temp_to6(:::: $\left.)^{*} 100\right) /$ mat_temp_to6(end,:); mat_temp_to_n7 $=\left(\right.$ mat_temp_to $\left.7(:,:)^{*} 100\right) /$ mat_temp_to7(end,:); mat temp to $n 8=\left(\right.$ mat temp to $\left.8(:,:)^{*} 100\right) /$ mat temp to 8 (end,:); mat_temp_to_n9 $=$ (mat_temp_to9(:::: $\left.)^{*} 100\right) /$ mat_temp_to9(end,:); mat_temp_to_n10 $=\left(\right.$ mat_temp_to $\left.10(:,:)^{*} 100\right) /$ mat_temp_to $10($ end, $:)$;

$\%$ Matrix de angulo e tempo do joelho\%

$\mathrm{AJ} 1=$ [mat ang $j 1$ mat temp $j \mathrm{n}$ 1] $;$

AJ2 $=$ [mat_ang_j2 mat_temp_j_n2];

AJ3 $=$ [mat_ang_j 3 mat_temp_j_n3];

AJ4 $=$ [mat_ang_j4 mat_temp_j_n4];

AJ5 $=$ [mat_ang_j5 mat_temp_j_n5];

AJ6 $=$ [mat_ang_j6 mat_temp_j_n6];

AJ7 $=$ [mat_ang_j7 mat_temp_j_n7];

AJ8 $=$ [mat_ang_j8 mat_temp_j_n8];

AJ9 $=$ [mat_ang_j9 mat_temp_j_n9];

$\mathrm{AJ} 10=$ [mat_ang_j10 mat_temp_j_n10];

$\%$ Matrix de angulo e tempo do quadril\%

$A Q 1=$ [mat_ang_q1 mat_temp_q_n1];

AQ2 = [mat_ang_q2 mat_temp_q_n2];

AQ3 $=$ [mat_ang_q3 mat_temp_q_n3];

AQ4 = [mat_ang_q4 mat_temp_q_n4];

AQ5 = [mat_ang_q5 mat_temp_q_n5];

AQ6 $=$ [mat_ang_q6 mat_temp_q_n6];

$A Q 7=$ [mat_ang_q7 mat_temp_q_n7];

AQ8 = [mat_ang_q8 mat_temp_q_n8];

$A Q 9=$ [mat_ang_q9 mat_temp_q_n9];

$A Q 10=$ [mat_ang_q10 mat_temp_q_n10];

\%Matrix de angulo e tempo do tornozelo\%

ATO1 = [mat_ang_to1 mat_temp_to_n1];

ATO2 = [mat_ang_to2 mat_temp_to_n2]; 
ATO3 $=$ [mat ang to 3 mat temp to n3];

ATO4 = [mat_ang_to4 mat_temp_to_n4];

ATO5 = [mat_ang_to5 mat_temp_to_n5];

ATO6 $=$ [mat_ang_to6 mat_temp_to_n6];

ATO7 $=$ [mat_ang_to7 mat_temp_to_n7]

ATO8 $=$ [mat ang to 8 mat temp to $n 8$ ];

ATO9 = [mat_ang_to9 mat_temp_to_n9];

ATO10 = [mat_ang_to10 mat_temp_to_n10];

\%ldentificando como x e y\%

$\mathrm{x} 1=$ mat temp j $\mathrm{n} 1 ; \mathrm{y} 1=$ =mat ang $\mathrm{j} 1$

$\mathrm{x} 2=$ mat_temp_j_n2;y2=mat_ang_j2;

$\mathrm{x} 3=$ mat_temp_j_n3; $\mathrm{y} 3=$ mat_ang_ $\mathrm{j}$;

$\mathrm{x} 4=$ =mat_temp_inn 4 ; $4=$ =mat_ang_ 44

$\mathrm{x} 5=$ =mat_temp_j_n5;y5=mat_ang_j5;

$\mathrm{x} 6=$ =mat temp i n6;y6=mat ang $j 6$;

$x 7=$ mat_temp_j_n7; $y=$ mat_ang_ $j 7$

$\mathrm{x} 8=$ mat_temp_j_n8; $\mathrm{y} 8=\mathrm{mat}$ _ang_ $\mathrm{j} 8$

$\mathrm{x} 9=$ mat temp $\mathrm{j}$ n $9 ; \mathrm{y} 9=$ mat ang $j 9$;

x10=mat_temp_j_n10;y10=mat_ang_j10;

$\mathrm{x} 11=$ =mat_temp_q_n1;y11=mat_ang_q1; x12=mat_temp_q_n2;y12=mat_ang_q2; $\mathrm{x} 13=$ mat temp_q n3; $13=$ mat ang_q3; $\mathrm{x} 14=$ mat_temp_q_n4;y14=mat_ang_q4; $\mathrm{x} 15=$ mat temp q n5; $15=$ mat ang q5; $\mathrm{x} 16=$ mat_temp_q_n6;y16=mat_ang_q6; $\mathrm{x} 17=$ mat_temp_q_n7; $17=$ mat_ang_q7; $\mathrm{x} 18=$ mat temp q n8; $18=$ mat ang $\mathrm{q} 8$; x19=mat_temp_q_n9;y19=mat_ang_q9; x20=mat_temp_q_n10;y20=mat_ang_q10;

$\mathrm{x} 21=$ mat temp to $\mathrm{n} 1 ; \mathrm{y} 21=$ mat ang to 1 ; $\mathrm{x} 22=$ mat temp to $\mathrm{n} 2 ; \mathrm{y} 22=$ mat ang to2; x23=mat_temp_to_n3;y23=mat_ang_to3: $\mathrm{x} 24=$ mat temp to $\mathrm{n} 4 ; \mathrm{y} 24=\mathrm{mat}$ ang to 4 x25=mat_temp_to_n5;y25=mat_ang_to5; $\mathrm{x} 26=$ mat temp to $\mathrm{n} 6 ; \mathrm{y} 26=$ mat ang to 6 $\mathrm{x} 27=$ mat temp to $\mathrm{n} 7 ; \mathrm{y} 27=$ mat ang to 7 x28=mat_temp_to_n8;y28=mat_ang_to8; $\mathrm{x} 29=$ mat temp to $\mathrm{n} 9 ; \mathrm{y} 29=$ =mat ang to 9 ; x30=mat_temp_to_n10;y30=mat_ang_to 10 ;

$\mathrm{xi}=$ linspace $(0,100,100)$

$\%$ Create Vector Of Common X-Values

y1i = interp1(x1(:), y1(:), xi(:), 'linear', 'extrap'); \% Interploate Or Extrapolate To New ' $x$ ' Values y2i = interp1(x2(:), y2(:), xi(:), 'linear', 'extrap'); \% Interploate Or Extrapolate To New ' $x$ ' Values y3i = interp1(x3(:), y3(:), xi(:), 'linear', 'extrap'); \% Interploate Or Extrapolate To New ' $x$ ' Values y4i = interp1(x4(:), y4(:), xi(:), 'linear', 'extrap'); \% Interploate Or Extrapolate To New ' $x$ ' Values y5i = interp1(x5(:), y5(:), xi(:), 'linear', 'extrap'); \% Interploate Or Extrapolate To New ' $x$ ' Values y6i = interp1(x6(:), y6(:), xi(:), 'linear', 'extrap'); \% Interploate Or Extrapolate To New ' $x$ ' Values y7i = interp1(x7(:), y7(:), xi(:), 'linear', 'extrap'); \% Interploate Or Extrapolate To New ' $x$ ' Values y8i = interp1(x8(:), y8(:), xi(:), 'linear', 'extrap'); \% Interploate Or Extrapolate To New 'x' Values y9i = interp1(x9(:), y9(:), xi(:), 'linear', 'extrap'); \% Interploate Or Extrapolate To New ' $x$ ' Values y10i = interp1(x10(:), y10(:), xi(:), 'linear', 'extrap'); \% Interploate Or Extrapolate To New 'x' Values

y11i = interp1(x11(:), y11(:), xi(:), 'linear', 'extrap'); \% Interploate Or Extrapolate To New ' $x$ ' Values y12i = interp1(x12(:), y12(:), xi(:), 'linear', 'extrap'); \% Interploate Or Extrapolate To New ' $x$ ' Values y13i = interp1(x13(:), y13(:), xi(:), 'linear', 'extrap'); \% Interploate Or Extrapolate To New ' $x$ ' Values y14i = interp1(x14(:), y14(:), xi(:), 'linear', 'extrap'); \% Interploate Or Extrapolate To New ' $x$ ' Values y15i = interp1(x15(:), y15(:), xi(:), 'linear', 'extrap'); \% Interploate Or Extrapolate To New ' $x$ ' Values y16i = interp1(x16(:), y16(:), xi(:), 'linear', 'extrap'); \% Interploate Or Extrapolate To New ' $x$ ' Values y17i = interp1(x17(:), y17(:), xi(:), 'linear', 'extrap'); \% Interploate Or Extrapolate To New ' $x$ ' Values y18i = interp1(x18(:), y18(:), xi(:), 'linear', 'extrap'); \% Interploate Or Extrapolate To New ' $x$ ' Values y19i = interp1(x19(:), y19(:), xi(:), 'linear', 'extrap'); \% Interploate Or Extrapolate To New ' $x$ ' Values y20i = interp1(x20(:), y20(:), xi(:), 'linear', 'extrap'); \% Interploate Or Extrapolate To New ' $x$ ' Values

y21i = interp1(x21(:), y21(:), xi(:), 'linear', 'extrap'); \% Interploate Or Extrapolate To New ' $x$ ' Values y22i = interp1(x22(:), y22(:), xi(:), 'linear', 'extrap'); \% Interploate Or Extrapolate To New ' $x$ ' Values y23i = interp1(x23(:), y23(:), xi(:), 'linear', 'extrap'); \% Interploate Or Extrapolate To New ' $x$ ' Values y24i = interp1(x24(:), y24(:), xi(:), 'linear', 'extrap'); \% Interploate Or Extrapolate To New ' $x$ ' Values y25i = interp1(x25(:), y25(:), xi(:), 'linear', 'extrap'); \% Interploate Or Extrapolate To New ' $x$ ' Values y26i = interp1(x26(:), y26(:), xi(:), 'linear', 'extrap'); \% Interploate Or Extrapolate To New ' $x$ ' Values y27i = interp1 $(x 27(:), y 27(:), x i(:)$, 'linear', 'extrap'); \% Interploate Or Extrapolate To New ' $x$ ' Values y28i = interp1(x28(:), y28(:), xi(:), 'linear', 'extrap'); \% Interploate Or Extrapolate To New ' $x$ ' Values 
y29i = interp1(x29(:), y29(:), xi(:), 'linear', 'extrap'); \% Interploate Or Extrapolate To New ' $x$ ' Values y30i = interp1(x30(:), y30(:), xi(:), 'linear', 'extrap'); \% Interploate Or Extrapolate To New ' $x$ ' Values

y mean $j=$ mean ([y1i y2i y3i y4i y5i y6i y7i y8i y9i y10i], 2)

$\%$ Mean Of $Y$ Values

y_std_ $j=\operatorname{std}([y 1 i$ y2i y3i y4i y5i y6i y7i y8i y9i y10i],0,2); \% STD Of $Y$ Values

$y$ mean stdp $j=y$ mean $j+y$ std $j ; \%$ Mean + STD of $Y$ Values

y_mean_stdn_j $=y \_m e a n \_j-y \_s t d \_j ; \%$ Mean $-S T D$ of $Y$ Values

y_mean_std_j $=$ [y_mean_stdp_jy_mean_stdn_j]; \% Mean +-STD of $Y$ Values

figure(1)

$\operatorname{plot}\left(\mathrm{x} 1, \mathrm{y} 1,{ }^{\prime}-\mathrm{k}^{\prime}\right)$

hold on

plot(x2, y2, '-y')

$\operatorname{plot}\left(x 3, y 3,-m^{\prime}\right)$

plot $\left(x 4, y 4,-c^{\prime}\right)$

$\operatorname{plot}(x 5, y 5, '-g$ ')

$\operatorname{plot}\left(x 6, y 6,{ }^{-}-k^{\prime}\right)$

$\operatorname{plot}(x 7, y 7, '-y ')$

plot $(x 8, y 8,--m$ ')

$\operatorname{plot}\left(x 9, y 9,{ }^{-}-c^{\prime}\right)$

plot $(x 10, y 10, '-g ')$

plot(xi, y_mean_j, '-r', 'LineWidth',2)

plot(xi, y mean_std _i, 'b', 'LineWidth',2)

hold off

grid

legend('Data 1', 'Data 2', 'Data 3','Data 4', 'Data 5','Data 6', 'Data 7','Data 8', 'Data 9','Data 10', 'Data Mean','Data SD', 'Location','N')

$[x, y]=\operatorname{ginput}(3)$;

inicio_pj $=$ round $(x(1))$

meio $\mathrm{pj}=\operatorname{round}(x(2))$

fim $\_$pj $=\operatorname{round}(x(3))$;

Cont inicial $\mathrm{j}=\mathrm{y}$ mean $\mathrm{j}(1, \mathrm{:})$;

Pico_flex_cont_ $j=\min \left(y \_\right.$mean_j(1:inicio_pj,: $\left.)\right)$;

Pico ext cont $j=\max (y$ mean $j$ (inicio pj:meio pj,:));

Pico_flex_bal_j $=$ min(y_mean_j(meio_pj:fim_pj,:));

y_mean_q = mean([y11i y12i y13i y14i y15i y16i y17i y18i y19i y20i], 2); \% Mean Of $Y$ Values

y std $q=\operatorname{std}([y 11 i$ y12i y13i y14i y15i y16i y17i y18i y19i y20i],0,2); \% STD Of $Y$ Values

y_mean_stdp_q $=y \_m e a n \_q+y \_s t d \_q ; \%$ Mean +STD of $Y$ Values

y_mean_stdn_q $=y \_m e a n \_q-y \_s t d \_q ; \%$ Mean $-S T D$ of $Y$ Values

y_mean_std_q $=$ [y_mean_stdp_qy_mean_stdn_q ]; \% Mean +-STD of $Y$ Values

figure(2)

$\operatorname{plot}\left(x 11, y 11,{ }^{-}-k^{\prime}\right)$

hold on

$\operatorname{plot}\left(x 12, y 12,-k^{\prime}\right)$

$\operatorname{plot}(x 13, y 13, '-k ')$

$\operatorname{plot}\left(x 14, y 14,-k^{\prime}\right)$

$\operatorname{plot}\left(x 15, y 15, '-k^{\prime}\right)$

$\operatorname{plot}\left(x 16, y 16,-k^{\prime}\right)$

$\operatorname{plot}(x 17, y 17, '-k ')$

plot(x18, y18, '-k')

$\operatorname{plot}\left(x 19, y 19,-k^{\prime}\right)$

plot(x20, y20, '-k')

plot(xi, y mean q, '-r', 'LineWidth',2)

plot(xi, y_mean_std_q, 'b', 'LineWidth',2)

hold off

grid

legend('Data 1', 'Data 2', 'Data 3','Data 4', 'Data 5','Data 6', 'Data 7','Data 8', 'Data 9','Data 10', 'Data Mean','Data SD', 'Location','N')

Cont inicial $\mathrm{q}=\mathrm{y}$ mean $\mathrm{q}(1,:)$;

Pico flex cont $\mathrm{q}=\mathrm{y}$ _mean $\mathrm{q}(\mathrm{y}$ mean $\mathrm{j}==$ Pico flex cont $\mathrm{j},:)$;

Pico_ext_cont_q =y_mean_q(y_mean_j ==Pico_ext_cont_j,:);

Pico flex bal $q=y$ mean $q(y$ mean $j==P i c o$ flex bal $j,:)$; 
y std to $=\operatorname{std}([y 21 i$ y22i y23i y24i y25i y26i y27i y28i y29i y30i],0,2); \% STD Of $Y$ Values

y_mean_stdp_to $=y \_m e a n \_t o+y \_s t d \_t o ; \%$ Mean +STD of $Y$ Values

y_mean_stdn_to $=y \_m e a n \_t o-y \_s t d \_t o ; \%$ Mean $-S T D$ of $Y$ Values

y_mean_std_to $=$ [y_mean_stdp_toy_mean_stdn_to ]; \% Mean +-STD of $Y$ Values

figure(3)

plot(x21, y21, '-k')

hold on

$\operatorname{plot}\left(x 22, y 22,{ }^{-}-k^{\prime}\right)$

plot(x23, y23, '-k')

plot(x24, y24, '-k')

$\operatorname{plot}(x 25, y 25, '-k ')$

plot(x26, y26, '-k')

$\operatorname{plot}\left(x 27, y 27,{ }^{-}-k^{\prime}\right)$

plot(x28, y28, '-k')

$\operatorname{plot}\left(x 29, y 29, '-k^{\prime}\right)$

$\operatorname{plot}\left(x 30, y 30, '-k^{\prime}\right)$

plot(xi, y_mean_to, '-r', 'LineWidth',2)

plot(xi, y_mean_std_to, 'b', 'LineWidth',2)

hold off

grid

legend('Data 1', 'Data 2', 'Data 3','Data 4', 'Data 5','Data 6', 'Data 7','Data 8', 'Data 9','Data 10', 'Data Mean','Data SD', 'Location','N')

Cont_inicial_to $=y \_m e a n \_t o(1,:)$

Pico_flex_cont_to $=y \_$mean_to $\left(y \_m e a n \_j==P i c o \_f l e x \_c o n t \_j,:\right) ;$

Pico_ext_cont_to $=y \_m e a n \_t o\left(y \_m e a n \_j==P i c o \_e x t \_c o n t \_j,:\right)$;

Pico_flex_bal_to $=y \_m e a n \_t o\left(y \_m e a n \_j==P i c o \_f l e x \_b a l \_,:\right)$;

\%Comprimento, frequência e fases da passada.

$\%$ mat_temp_to $1=(0: 1:$ length (mat_ang_to 1$)-1)^{\prime *} 4.167$

$\%$ mat_temp_to_n1 $=\left(\right.$ mat_temp_to $\left.1(:,:)^{*} 100\right) /$ mat_temp_to1(end,:);

ML1 env $=M L 1 *(-1) ; M L 2$ env $=M L 2 *(-1) ; M L 3$ env $=M^{*} 3^{*}(-1) ; M L 4$ env $=M L 4 *(-1) ; M L 5$ env $=M L 5^{*}(-1)$;

ML6_env $=M L 6^{*}(-1) ; M L 7 \_$env $=M L 7^{*}(-1) ; M L 8 \_$env $=M L 8^{*}(-1) ; M L 9 \_$env $=M^{*} 9^{*}(-1) ; M L 10 \_$env $=M L 10^{*}(-1)$;

ML1_max $=\max \left(M L 1 \_e n v(:, 1)\right) ; M L 1 \_p a s s a d a=\left(M L 1 \_m a x-M L 1 \_e n v(1,1)\right)+\left(M L 1 \_m a x-M L 1 \_e n v(e n d, 1)\right)$;

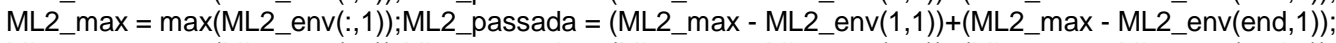

ML3 $\max =\max (M L 3$ env(:,1));ML3 passada $=($ ML3 max - ML3 env $(1,1))+(M L 3$ max - ML3 env(end,1));

ML4_max $=\max \left(\mathrm{ML} 4 \_\right.$env(:,1));ML4_passada $=(\mathrm{ML} 4$ max $-\mathrm{ML} 4$ _env $(1,1))+(\mathrm{ML} 4$ max $-\mathrm{ML} 4$ _env(end,1) $)$;

ML5_max $=\max \left(M L 5 \_e n v(:, 1)\right) ; M L 5 \_p a s s a d a=\left(M L 5 \_m a x-M L 5 \_e n v(1,1)\right)+\left(M L 5 \_m a x-M L 5 \_e n v(e n d, 1)\right)$;

ML6_max $=\max \left(\right.$ ML6_env(:,1));ML6_passada $=($ ML6_max - ML6_env $(1,1))+\left(M L 6 \_m a x-M L 6 \_e n v(e n d, 1)\right)$;

ML7_max $=\max \left(M L 7 \_e n v(:, 1)\right) ; M L 7 \_$passada $=\left(M L 7 \_m a x-M L 7 \_e n v(1,1)\right)+\left(M L 7 \_m a x-M L 7 \_e n v(e n d, 1)\right)$;

ML8 $\max =\max (M L 8$ env(:,1));ML8 passada $=($ ML8 $\max -$ ML8 env $(1,1))+(M L 8$ max - ML8 env(end 1$)) ;$

ML9_max $=\max \left(M L 9 \_e n v(:, 1)\right) ; M L 9 \_p a s s a d a=\left(M L 9 \_m a x-M L 9 \_e n v(1,1)\right)+\left(M L 9 \_m a x-M L 9 \_e n v(e n d, 1)\right)$;

ML10_max $=\max \left(M L 10 \_e n v(:, 1)\right) ; M L 10 \_p a s s a d a=\left(\bar{M} L 10 \_m a x-M L 10 \_e n v(1,1)\right)+\left(M L 10 \_m a x-M L 10 \_e n v(e n d, 1)\right)$;

ML1_temp = find $\left(M L 1 \_e n v(:, 1)==M L 1 \_m a x\right) ; \quad M L 1 \_c o n t a t o=$ mat_temp_to1(ML1_temp(1),1);ML1_contato_n = mat temp to $\mathrm{n} 1(\mathrm{ML} 1$ temp(1), 1$)$;

ML2_temp $=$ find(ML2_env(:,1) == ML2_max); ML2_contato = mat_temp_to2(ML2_temp(1),1);ML2_contato_n = mat_temp_to_n2(ML2_temp (1), 1);

ML3_temp $=$ find $\left(M L 3 \_e n v(:, 1)==\right.$ ML3_max); ML3_contato = mat_temp_to3(ML3_temp(1),1);ML3_contato_n = mat_temp_to_n3(ML3_temp (1), 1 );

ML4 temp = find (ML4 env $(:, 1)==$ ML4 max); ML4 contato = mat temp to4(ML4 temp(1),1);ML4 contato $n=$ mat_temp_to_n4(ML4_temp(1),1);

ML5_temp $=$ find $\left(M L 5 \_\right.$env $(:, 1)==$ ML5_max); ML5_contato = mat_temp_to5(ML5_temp(1),1);ML5_contato_n = mat temp to n5(ML5 temp(1), 1$)$;

ML6_temp $=$ find(ML6_env(:,1) == ML6_max); ML6_contato = mat_temp_to6(ML6_temp(1),1);ML6_contato_n = mat temp to n6(ML6 temp(1), 1):

ML7_temp $=$ find $\left(M L 7 \_e n v(:, 1)==\right.$ ML7_max); ML7_contato = mat_temp_to7(ML7_temp(1),1);ML7_contato_n = mat_temp_to_n7(ML7_temp(1), 1$)$;

ML8_temp = find $\left(M L 8 \_e n v(:, 1)==\right.$ ML8_max); ML8_contato = mat_temp_to8(ML8_temp(1),1);ML8_contato_n = mat_temp_to_n8(ML8_temp(1), 1 );

ML9 temp = find(ML9 env(:,1) == ML9 max); ML9 contato = mat temp to9(ML9 temp(1),1);ML9 contato $\mathrm{n}=$ mat_temp_to_n9(ML9_temp(1), 1$)$;

ML10_temp $=\overline{\text { find }}\left(\mathrm{ML} 10 \_\right.$env $(:, 1)==$ ML10_max $) ; M L 10 \_$contato $=$mat_temp_to10(ML10_temp(1),1);ML10_contato_n = mat_temp_to_n10(ML10_temp(1),1);

mat contato = [ML1 contato; ML2 contato; ML3 contato; ML4 contato; ML5 contato; ML6 contato; ML7 contato; ML8_contato; ML9_contato; ML10_contato];

mat_contato_n = [ML1_contato_n; ML2_contato_n; ML3_contato_n; ML4_contato_n; ML5_contato_n; ML6_contato_n; ML7_contato_n; ML8_contato_n; ML9_contato_n; ML10_contato_n];

mat_fim = [mat_temp_to1(end); mat_temp_to2(end); mat_temp_to3(end); mat_temp_to4(end); mat_temp_to5(end); mat_temp_to6(end); mat_temp_to7(end); 
mat_temp_to8(end); mat_temp_to9(end); mat_temp_to10(end)];

mat_contato mean $=$ mean $($ mat contato);

mat_contato_n_mean $=$ mean $($ mat_contato_n);

mat_fim_mean $=$ mean $($ mat_fim);

mat_aerea_n_mean $=100$ - mat_contato_n_mean;

mat_aerea_mean = mat_fim_mean - mat_contato_mean;

mat_passada $=$ [ML1_passada; ML2_passada; ML3_passada; ML4_passada; ML5_passada; ML6_passada; ML7_passada;

ML8_passada; ML9_passada; ML10_passada];

mat_passada_mean = mean(mat_passada);

mat_velocidade_cm_ms = mat_passada./mat_fim;

mat_velocidade_cm_s $=$ mat_velocidade_cm_ms*1000; mat_velocidade_cm_s_mean $=$ mean $\left(\right.$ mat $\left.\_v e l o c i d a d e \_c m \_s\right)$;

mat_velocidade_m_min $=$ mat_velocidade_cm_ms ${ }^{*} 600 ;$ mat_velocidade_m_min_mean $=$ mean(mat_velocidade_m_min);

mat_freq_passada_min $=60000$./mat_fim; mat_freq_passada_min_mean $=$ mean (mat_freq_passada_min);

mat_freq_passada_s $=1000 . / m a t \_f i m ;$ mat_freq_passada_s_mean $=$ mean(mat_freq_passada_s);

\%Dados organizados para Workspace

A1_ANGULOS_QUADRIL $=\left[y \_m e a n \_q y \_m e a n \_s t d p \_q y \_m e a n \_s t d n \_q\right]$;

A2_ANGULOS_JOELHO $=\left[y \_\right.$mean_jy_mean_stdp_jy_mean_stdn_j];

A3_ANGULOS_TORNOZELO $=$ [y_mean_toy_mean_stdp_toy_mean_stdn_to];

A4_VELOCIDADE_CMS_MMIN = [mat_velocidade_cm_s_meanmat_velocidade_m_min_mean];

A5_FASE_CONTATO_CONTATON = [mat_contato_meanmat_contato_n_mean];

A6_FASE_AEREA_AEREAN $=$ [mat_aerea_meanmat_aerea_n_mean];

A7_AMPLITUDE_PASSADA = mat_passada_mean;

A8_FREQUENCIA_PASSADA_S_MIN = [mat_freq_passada_S_meanmat_freq_passada_min_mean];

A9_PICOS_ANGULOS

Cont_inicial_qPico_flex_cont_qPico_ext_cont_qPico_flex_bal_q;
Cont_inicial_toPico_flex_cont_toPico_ext_cont_toPico_flex_bal_to]

\%Exportando dados para excel

header_dados1 = \{'MÉDIA','DP+','DP-' $\}$;

dados1 = num2cell(A1_ANGULOS_QUADRIL);

output_mat_dados $1=$ vertcat(header_dados1, dados1);

header_dados2 = \{'MÉDIA','DP+','DP-' $\}$;

dados2 = num2cell(A2 ANGULOS JOELHO);

output_mat_dados2 = vertcat(header_dados2, dados2);

header dados3 = \{'MÉDIA','DP+','DP-' $\}$;

dados3 = num2cell(A3_ANGULOS_TORNOZELO);

output_mat_dados3 = vertcat(header_dados3, dados3);

header dados4 = \{'VELOCIDADE $(\mathrm{cm} / \mathrm{s})^{\prime}$, 'VELOCIDADE $(\mathrm{m} / \mathrm{min})$ ', 'FASE CONTATO(ms)','FASE CONTATON(\%)', 'FASE

AEREA(ms)','FASE_AEREA(\%)', 'AMPLITUDE PASSADA(cm)', 'FREQUENCIA PASSADA (p/s)','FREQUENCIA

PASSADA_MIN(p/min)'\}; mat dados 4

=[mat_velocidade_cm_s_meanmat_velocidade_m_min_meanmat_contato_meanmat_contato_n_meanmat_aerea_meanmat_aerea _n_meanmat_passada_meanmat_freq_passada_s_meanmat_freq_passada_min_mean];

dados 4 = num2cell(mat_dados4);

output_mat_dados $4=$ vertcat(header_dados4, dados 4$)$;

header_dados5 = \{'CIJ','PFCJ','PECJ','PFBJ','CIQ','PFCQ','PECQ','PFBQ','CITO','PFCTO','PECTO','PFBTO'\};

mat_dados5

[Cont_inicial_jPico_flex_cont_jPico_ext_cont_jPico_flex_bal_j;

inicial_toPico_flex_cont_toPico_ext_cont_toPico_flex_bal_to];

dados $5=$ num2cell(mat_dados5);

output_mat_dados5 = vertcat(header_dados5, dados5);

filename_excel $=$ input('Colocar o nome do arquivo entre aspas e formato .xlsx? ');

xlswrite(filename_excel,output_mat_dados2,'JOELHO')

xlswrite(filename_excel,output_mat_dados3,'TORNOZELO')

xlswrite(filename_excel,output_mat_dados1,'QUADRIL')

xlswrite(filename excel,output mat dados4,'DADOS')

xlswrite(filename_excel,output_mat_dados5,'PICOS') 
Anexo 3. Relatório de Bolsa de Estágio e Pesquisa no Exterior (BEPE-FAPESP)

\section{RESEARCH INTERNSHIP ABROAD REPORT}

(BEPE-FAPESP: 2018/23457-0)

Awardee Student: Felipe Bruno Dias de Oliveira ${ }^{1,2}$

Foreign Advisor: Tonia Vincent ${ }^{2}$

Advisor: Mario Ferretti Filho ${ }^{1}$

1-Hospital Israelita Albert Einstein, São Paulo, SP, Brazil

2-Oxford University, Oxford, UK 


\section{Description}

I had the opportunity to undertake a research internship abroad, under the guidance of Professor Tonia Vincent. The internship was carried out at the "The Kennedy Institute of Rheumatology" laboratory, based in Oxford - United Kingdom. This laboratory is part of the Medical Sciences Division in the University of Oxford and is a research centre exclusively dedicated to rheumatic diseases research. To be accepted at the University, it was necessary to fulfil prerequisites regarding the "Recognized Student" or "Visiting Research Only" student category. This category is specific for students enrolled in short term courses or who will carry out research activities up to one year

\section{Scientific activities}

Throughout this internship, I was able to actively participate in scientific meetings and events within the field of rheumatology. The Vincent group lab meetings and the Institute's Osteoarthritis Centre meetings took place weekly. The lab meetingsgoal was to present data obtained during the previous week, by all group members, followed bydiscussions and directions for the project. The Osteoarthritis Centre meetings were composed of all researchers and students from the Institute with projects related to OA. The objective was to present and discuss projects and articles within the $\mathrm{OA}$ field. In addition to these meetings, the Institute hosted lectures and presentations by renowned national and international researchers.

Besides scientific meetings, I was admitted as a University student and at the end of each term it was necessary to write a "Graduate Supervision Report" (GSR). The GSR consisted of a description of your main activities and advances during the previous three months, the identified next steps, how many times you had met with your advisor, training conducted or that would be necessary for the next term, and if you had any concerns about the project progress. My advisor at the University (Tonia Vincent) received the report and also commented on her perceptions on the same issues. Finally, two graduate directors had access to the reports for approval. During my internship at the University, I wrote this report four times, all of which were approved (See attachment).

As for scientific events, I attended the "Cutting Edge Osteoarthritis 2019", conducted by the "Centre for Osteoarthritis Pathogenesis Versus Arthritis" and also attended the "Osteoarthritis Centre Annual Review Meeting 2019". The first event 
was an international symposium where themes and emerging technologies within the OA field were discussed. The second event was dedicated to the presentation of results and scientific advances obtained by the Osteoarthritis Centre to members of the Kennedy Institute's Advisory Board, composed of scientists and patients. At this event, I was responsible for presenting orally the topic "RNAScope $\AA$ in Articular Cartilage".

\section{Training and learning of new laboratory techniques}

During the first month, I attended basic training on occupational safety, biosafety and fire management. After starting laboratory activities, I did the "Schedule 1" qualification training, conducted by the Institute's Biological Support Unit. This training allows you to perform simple handling and mice euthanasia, in accordance with UK Home Office legislation for animal research. I also received training for confocal microscopy operation, carried out by the Institute's responsible technician.

While developing my project, I had contact with several new laboratory techniques. The list below refers to techniques I learned and used in my project or in projects of other group members:

- $\quad$ Cell culture:

- Isolation of mesenchymal stem cells from mice epididymal adipose tissue;

- Isolation of chondrocytes from pig trotters metacarpophalangeal joint cartilage;

- Chondrogenic disc assay, performed on Trans Well plates;

- Chondrogenic pellet assay, performed in $15 \mathrm{ml}$ tubes.

- Testing and analysis of cell migration "scratch assay".

-Preparation of cartilage injury conditioned media from pig trotter metacarpophalangeal joint cartilage;

- RNA extraction:

- Monolayer adhered cells, using TRIzol;

- Chondrogenic pellet, combining silica sand and TRIzol;

- Cartilage explant from pig trotters and mouse whole joint (knee), associating liquid nitrogen pulverization and TRIzol.

- Quantification of RNA by NanoDrop.

- Gene expression analysis:

- Preparation of complementary DNA;

- Real-time PCR using TaqMan and SYBR Green.

- Cryostat: 
- Positioning and sectioning of mouse knee joint for the animal model of focal cartilage scratch injury (trochlear groove);

- Kawamoto'stape usage for cryosectioning.

- RNAScope ${ }^{\circledR}$ for articular cartilage:

- Sample preparation and processing for frozen sections;

- Image acquisition by confocal microscopy;

- Analysis and image processing of confocal microscopy.

\section{Research Project}

The project below describes the main findings obtained and the laboratory techniques used during its development. 
TO INVESTIGATE HOW FGF2 AND LATENT TGF- $\beta$ CONTROLS THE MIGRATION AND DIFFERENTIATION OF MESENCHYMAL STEM CELLS AT THE SITE OF CARTILAGE INJURY.

\section{INTRODUCTION}

Osteoarthritis $(O A)$ is a worldwide disease, among the 10 leading causes of "Years Lived With Disease" in many countries, and considered the second most prevalent musculoskeletal disease according to the World Health Organization. ${ }^{(1)}$ Characterized as progressive degeneration of joint articular cartilage, $O A$ is an agerelated disease that starts usually after age $50^{(2)}$. Its progression can impair body movement to the extent that a total joint replacement surgery is necessary. ${ }^{(3)}$

$O A$ is still a non-curable disease, however there are several proposed non-surgical treatments ${ }^{(3-5)}$ and regenerative medicine approaches ${ }^{(6)}$ designed to treat OA. One in particular is the use of Mesenchymal Stem Cells (MSCs). ${ }^{(7,8)}$

MSCs are known by their in-vitro multipotent capacity to differentiate into the three principal mesenchymal lineages; chondrocyte, osteoblast and adipocyte. ${ }^{(9)}$ MSCs also promote tissue homeostasis through immunomodulation, cytokines and growth factor release. ${ }^{(9)}$ McGonagol 2017, ${ }^{(10)}$ argued that joint resident MSCs are present in the synovial membrane $\left(\mathrm{CD} 271^{+} \mathrm{CD} 73^{+}\right.$and $\left.\mathrm{CD} 271^{+} \mathrm{CD} 44^{+}\right)$, synovial fluid and joint adipose tissue, acting on joint homeostasis either by paracrine activity or homing to the cartilage injury site through the synovial fluid. ${ }^{(10)} \mathrm{Homing}$ and migratory potential of local ${ }^{(10)}$ or transplanted ${ }^{(11)}$ MSCs to sites of injury have been shown for different animal models. Nevertheless, it is not clear how osteoarthritic joints signal MSC homing and activity. ${ }^{(11)}$

FGF2 stimulation is known to enhance migration of MSCs. ${ }^{(12)}$ A recent study of Awan et al. 2018 ${ }^{(12)}$ showed that after FGF2 stimulation, MSCs increase their migratory potential mainly by enhanced fucosylation of cell membrane $\mathrm{N}$-glycan Integrins. ${ }^{(12)}$ Fibroblast Growth Factor 2 (FGF2) is a mitogenic and migratory factor highly abundant in the pericellular matrix (PCM) of articular cartilage ( $A C$ ) chondrocytes. ${ }^{(13,14)}$ Upon injury, FGF2 is released from heparan sulfate-bound stores in the PCM to initiate an important stress response. The consequences of this release seems to be beneficial to the cartilage injury repair process, as mice deficient in FGF2 develop accelerated OA. ${ }^{(15)}$ Recent data from Tonia Vincent's group, presented at 
OARSI 2018 congress, showed that FGF2 interacts with MSCs to promote cartilage regeneration. DBA1 mice normally exhibit spontaneous focal cartilage defect repair. However, FGF2 ${ }^{-/}$DBA1 mice have reduced regenerative capacity following focal cartilage injury. Also, FGF2 increased MSCs mobility suggesting that this may be one mechanism for promoting tissue regeneration. However, supplementation of chondrogenic medium with FGF2 suppresses chondrogenesis of MSCs, indicating that FGF's role may be to mobilize MSCs and maintain them in a non-differentiated state until they are able to be activated by TGF- $\beta$, the key chondrogenic growth factor. ${ }^{(16)}$ As observed by Correa et al. ${ }^{(17)}$ the beneficial effect of FGF2 for chondrogenesis of MSCs, seems to be during the expansion phase, before the chondrogenic differentiation, increasing proliferation, upregulating genes such SOX9 and altering the ratio of FGFR3/FGFR1.

Another factor released from PCM after injury is Latent TGF- $\beta .{ }^{(13)}$ This latent complex of TGF- $\beta$ requires the cell surface receptor Betaglycan, also known as TGF- $\beta$ R3, in order to become activated. ${ }^{(18)}$ Tang et al. 2018 showed that the interaction of Latent TGF- $\beta$ and Betaglycan is mediated by Connective-Tissue Growth Factor (CTGF). ${ }^{(19)}$ The chondrogenic potential of TGF- $\beta$ on MSC is well known, and stimulation MSCs with TGF- $\beta$ enhances gene expression of anabolic chondrogenic markers. ${ }^{(17)}$ TGF- $\beta$, unlike FGF2, arrests the cell cycle and regulates chondrogenesis. ${ }^{(20)}$ Also, as shown in different cancer cells types, TGF- $\beta$ R3 is a potent metastatic inhibitor by reducing cell migration independently of TGF- $\beta$ activators or inhibitors. $^{(21)}$

Together these studies suggest that there may be a time-regulated and coordinated mechanism by which FGF2, through regulation of TGF- $\beta R 3$, and Latent TGF- $\beta$ stimulate MSCs to effect cartilage regeneration. Therefore, the hypothesis this project tested was that FGF2 released upon articular cartilage injury primes MSCs for subsequent activation of Latent TGF- $\beta$ by regulating TGF- $\beta$ R3.

\section{Justification}

Results from my PhD project in Brazil (2015/14444-3), showed that MSCs transplanted intra-articularly survive for one week inside the OA joint. Also, it was possible to see in one animal, homing of MSCs to the OA joint eight hours after intravenous transplant. Likewise, in our serum samples we found modulation of inflammatory markers after one week of MSCs transplantation by either injection routes. 
This modulation was confirmed by analyses of synovial fluid (joint washout) samples four weeks after MSCs transplantation for the intra-articular injection treatment group. Considering the project goals were to understand more about MSCs homing and regenerative capacity in $O A$, it was of great interest and importance to address this putative FGF2 - Latent TGF- $\beta$ - TGF- $\beta$ R3 dependent regulation of MSCs after cartilage injury in the osteoarthritic environment.

\section{Objectives}

1) To evaluate the expression level of TGF- $\beta R 3$ on MSCs and its regulation following FGF2 and TGF $\beta$ stimulation

2) To assess the ability of FGF2 to activate the Latent TGF- $\beta$ complex in vitro

3) To examine the evidence for regulation of these molecules in vivo following focal cartilage repair

\section{METHODS}

All procedures were approved by the local ethics committee and the UK Home Office. Surgeries were carried out by licenced personnel and humanized killing of animals performed accordingly to Schedule 1 regulated procedures. ${ }^{(22)}$

\section{Mesenchymal stem cell isolation}

MSCs were isolated from the epididymal fat pad of 6-week-old Wild Type C57BL/6J mice (mAT-MSCs) $(\mathrm{N}=3)$ by adhesion to plastic. Primarily, epididymal fat pads were collected into serum-free medium ( $\alpha$-MEM+Glutamax, $1 \%$ PenicillinStreptomycin - Gibco®) and digested with $4 \mathrm{mg} / \mathrm{ml}$ Collagenase A (Roche ${ }^{\circledR}$ ) for $45 \mathrm{~min}$ at $37^{\circ} \mathrm{C}$ on a tube shaker (120 RPM). Then, the fat pad digest was passed through a $70 \mu \mathrm{m}$ cell strainer into a new $15 \mathrm{ml}$ tube and centrifuged (1200 RPM $\times 10$ minutes). Supernatant was discarded and cells re-suspended in growth medium containing fetal bovine serum (FBS) ( $\alpha$-MEM+Glutamax, $1 \%$ Penicillin-Streptomycin, 20\% FBS; Gibco®). After being homogenised, cells were cultured on $10 \mathrm{~cm}$ Petri-dishes overnight. Medium was discarded and the plate washed 5 times with PBS to remove non-adherent cells (passage zero - P0). Cells were cultured in growth medium and sub-cultured (culture passage) when the plate reached $90 \%$ confluency. Medium was changed every two days. Cells were counted (EVE® Automatic cell counter) and plated at $5 \times 10^{5}$ 
cells $/ \mathrm{cm}^{2}$ on a 6-well plate with 1-2 $\mathrm{ml}$ of MSCs growth medium for gene expression experiments. Cells were left to adhere to the plate for 24 hours and reach $80 \%$ of confluence before any experiment started.

\section{Porcine Trotter}

Porcine chondrocytes (pChondro) were isolated from pig trotter metacarpophalangeal (MCP) joints. The same tissue was also used to generate conditioned medium (CM) from injured (explanted) articular cartilage (injury $\mathrm{CM}$ ). Porcine trotter samples were used on the same day of arrival to the laboratory. Before any procedure, the trotter was washed with distilled water $\left(\mathrm{dH}_{2} \mathrm{O}\right)$ and submerged in Rely+OnVirkon (RELYON®) 1\% inside a bucket, for at least 20 minutes. Before dissection, it was washed with $\mathrm{dH}_{2} \mathrm{O}$ to remove the excess of Virkon and sprayed with ethanol $70 \%$. Using a scalpel $\left(n^{\circ} 22\right)$ the skin and digits were removed. Before opening the joint it was sprayed with ethanol $70 \%$ and brought inside a tissue culture hood. Figure 1 shows the dissection steps and joint quadrants. 


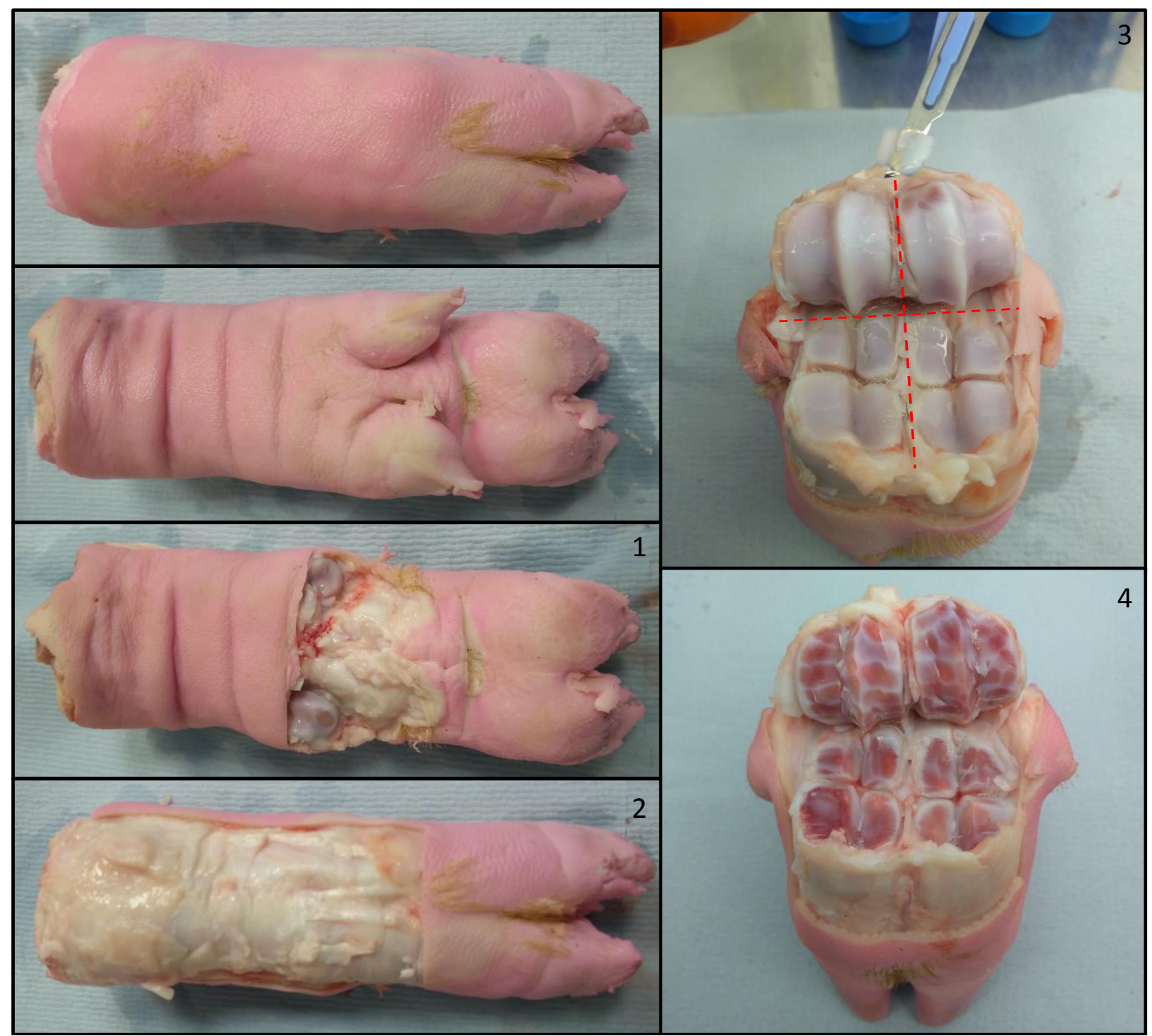

Figure 1. Porcine trotter's metacarpophalangeal (MCP) joint dissection. 1-2: digits and skin removal; 3-4: before and after cartilage collection. Dashed red lines: joint quadrants.

\section{Porcine chondrocyte isolation}

Cartilage explants were collected into a $50 \mathrm{ml}$ tube containing 10 ml/joint of Dulbecco's Minimum Essential Medium (DMEM) pChondro growth medium (DMEM, 1\% Penicillin-Streptomycin, 10\% FBS; Gibco®). Explants were washed twice with serum-free medium and supernatant discarded. Then, $1 \mathrm{mg} / \mathrm{ml}$ of Collagenase $A$ was added to $10 \mathrm{ml} / \mathrm{joint}$ of $\mathrm{pChondro} \mathrm{growth} \mathrm{medium.} \mathrm{Cartilage} \mathrm{was} \mathrm{digested} \mathrm{overnight}$ $\left(\approx 16\right.$ hours) at $37^{\circ} \mathrm{C}$ on a tube shaker (180 RPM). The digest content was passed through a $70 \mu \mathrm{m}$ cell strainer and centrifuged (1500 RPM $\times 5$ minutes). The pellet was resuspended in $20 \mathrm{ml}$ serum-free medium (DMEM, 1\% Penicillin-Streptomycin; Gibco®) and the centrifugation step were repeated, three times. Cells were counted (EVE® 
Automatic cell counter) and plated at $1,5 \times 10^{6}$ cells/well on a 6-well plate with 1-2 $\mathrm{ml}$ of medium for gene expression experiments. Cells were left to adhere to the plate for 24 hours before any experiment started. For experiments, cells from passage four up to passage eight were used.

\section{Porcine injury condition medium (CM)}

The joint was divided in 4 quadrants and each quadrant collected/processed within five minutes before the incubation step. After collection of cartilage in one $1,5 \mathrm{ml}$ tube, the explants were washed three times with $1 \mathrm{ml}$ of serumfree medium to remove blood and synovial fluid. Then, the explants were thoroughly cut with a scalpel $\left(n^{\circ} 15\right), 400 u l$ of fresh serum-free medium was added and incubated at $37{ }^{\circ} \mathrm{C}$ with $5 \% \mathrm{CO}_{2}$ for 30 minutes. After incubation the supernatant was collected and stored at -20 . Once all samples were processed, tubes with cartilage were weighted to determine the amount of $\mathrm{CM}$ possible to produce at $0,5 \mathrm{~g} / \mathrm{ml}$ (cartilage/ medium). All CM samples were pipetted into one $50 \mathrm{ml}$ tube and the volume adjusted to reach the desired concentration. To remove chondrocytes and cartilage debris the CM was centrifuged at $3000 \mathrm{~g} \times 10$ minutes and supernatant transferred to a new $50 \mathrm{ml}$ tube to, twice. Lastly, CM was sterilized through a $0,2 \mu \mathrm{m}$ syringe filter into a new tube and froze at -20 or -80 until use. A small volume of sterilized $\mathrm{CM}(5 \mathrm{ml})$ was passed through a Heparin binding Growth Factor (HbGF) Sepharose column (HiTrap $\AA$ Heparin High Performance MERCK $($ ) and analysed by chromatography. Protein content of flow through tubes were analysed by Ponceau $S$ staining and the samples with highest staining used for experiments. These samples were mixed, sterilized again through a 0,2 $\mu \mathrm{m}$ syringe filter and used as HbGF depleted condition medium (HbGF-depl-CM).

\section{RNA extraction for pChondro and MSCs (monolayer)}

Cell samples on 6 well plates were lysed with $350 \mathrm{ul} \mathrm{TRIzol}^{\mathrm{TM}}$ $\left(\right.$ Ambio $\AA$ ) and transferred to $1,5 \mathrm{ml}$ tube to be stored at $-80{ }^{\circ} \mathrm{C}$ or continue with extraction. Samples were placed in an orbital mixer and vigorously mixed for 5 minutes at room temperature. Supernatant was transferred to new $1,5 \mathrm{ml}$ tubes and $200 \mu \mathrm{l} 1$ Bromo-3- chloropropane (Sigma-Aldrich $\AA$ ) was added. Samples were vortexed for 5 seconds, left at room temperature for 5 min and centrifuged (13000 RPM $\times 10$ minutes) at $4^{\circ} \mathrm{C}$ to phase separate. RNA transparent phase was collected and added to equal volume of $70 \%$ ethanol. Samples were either stored overnight or immediately run 
through mini spin columns from Qiagen RNeasy Kit (Hilden®). Purity and concentration of RNA in each sample were determined by absorbance at $230 \mathrm{~nm}, 260 \mathrm{~nm}$ and $280 \mathrm{~nm}$ using a NanoDrop spectrophotometer (Thermo Scientific $®$ ).

\section{Reverse transcription to complementary DNA (cDNA)}

Reverse transcription of RNA to CDNA was performed with a High Capacity cDNA Reverse Transcription Kit (Applied Biosystems ${ }^{\text {TM }}$ - ThermoFisher ${ }^{\circledR}$ ) for $100-200 \mathrm{ng}$ of RNA/sample. A $20 \mu \mathrm{l}$ reaction were run in a thermocycler at: $25^{\circ} \mathrm{C} \times 10$ minutes; $37^{\circ} \mathrm{C} \times 2$ hours; $85^{\circ} \mathrm{C} \times 5$ minutes; cooled down to $4^{\circ} \mathrm{C}$ until samples were removed and stored at $-20^{\circ} \mathrm{C}$. Sample volume was adjusted to $1 \mathrm{ng} / \mu \mathrm{l}$ in RNAse-free water.

\section{Real Time Quantitative Polymerase Chain Reaction (qPCR)}

Samples were pipetted in a 384 well plate in duplicate. The PCR reaction was carried out by a ViiATM 7 Real-Time PCR System (Applied Biosystems ${ }^{\text {TM }}$ ThermoFisher $\left.{ }^{\circledR}\right)$. Relative gene expression was calculated using the $\Delta \Delta \mathrm{Ct}$ method with control genes.

Fast SYBR Green PCR Master Mix

A $10 \mu \mathrm{l}$ reaction/sample was carried out using $1 \mathrm{ng}$ of cDNA, $2 \mu \mathrm{l}$ of RNAse-free water, $2 \mu \mathrm{l}$ of forward+reverse primer mix and $5 \mu$ of SYBR Green PCR Master Mix (ThermoFisher®)

Table 1. SYBR Green mouse primers

\begin{tabular}{|c|c|c|}
\hline Gene & Forward sequence (5' to 3') & Reverse sequence (5' to $\mathbf{3}^{\prime}$ ) \\
\hline ACTB & GTG ACG TTG ACA TCC GTA AAG A & GCC GGA CTC ATC GTA CTC C \\
\hline TGF- $\beta$ R3 & GGT GTG AAC TGT CAC CGA TCA & GTT TAG GAT GTG AAC CTC CCT TG \\
\hline COL2 & CCT CAA GGC AAA GTT GGT CCT & CTC CCG TCT CAC CGT CTT TT \\
\hline
\end{tabular}


Table 2. SYBR Green porcine primers

\begin{tabular}{|c|c|c|}
\hline Gene & Forward sequence (5' to $\mathbf{3}^{\prime}$ ) & Reverse sequence (5' to $\mathbf{3}^{\prime}$ ) \\
\hline 18 s & TGC AGA ATC CTC GCC AAT ACA & AGT CGC TCC AAG TCT TCA CG \\
\hline TGF- $\beta$ R3 & CTC GAA CCC CTA CAG TGC TT & ATG TTA CTG GAC TGT AGC CAT \\
\hline COL2 & CAG GGG TGA ACG AGG TTT C & AAT ACC AGC AGC TCC CCT CT \\
\hline ACAN & CCC ACT AGT GCA GCA ACA GA & AGG GTA GAT GGC TGC TCT GA \\
\hline
\end{tabular}

TaqMan® Master Mix

A $10 \mu \mathrm{l}$ reaction/sample was carried out using $1 \mathrm{ng}$ cDNA (1 $\mu \mathrm{l}), 3,5 \mu \mathrm{l}$ of RNAse-free water; $5 \mu \mathrm{l} 2 \mathrm{X}$ TaqMan $\AA$ universal PCR master mix (Applied Biosystems $^{\mathrm{TM}}$ - ThermoFisher ${ }^{\circledR}$ ) and $0.5 \mu \mathrm{l} 20 \mathrm{X}$ TaqMan ${ }^{\circledR}$ primers.

Table3.TaqMan $\AA$ mouse primers

\begin{tabular}{|c|c|}
\hline Gene & Primer ID \\
\hline GAPDH & Mm01180221_g1 \\
\hline FGFR1 & Mm00438930_m1 \\
\hline FGFR2 & Mm00438941_m1 \\
\hline FGFR3 & Mm00433294_m1 \\
\hline COL2 & Mm01309556_g1 \\
\hline ACAN & Mm00545808_g1 \\
\hline
\end{tabular}

\section{MSC and pChondro stimulation/inhibition}

For all cell culture experiments, cells were washed with PBS 1X and serum-starved for four to six hours in serum free medium. Insulin-Transferrin-Selenium (ITS) Liquid Media Supplement 100x (MERCK®) was used as a substitute of FBS for serum-starvation and cellular stimulation/inhibition conditions, at 1:100 concentration (ITS/medium). Zero-hour time points were collected just before stimulation. Growth factors concentration were: Fibroblast Growth Factor 2(FGF2) - 20ng/ml; Fibroblast Growth Factor Receptor Inhibitor (SB402451, FGFRi) - 250nM; Transforming Growth Factor Beta 3 (TGF $3-3)$ - 10ng/ml.

\section{In vivo Cartilage focal injury model}

Surgical procedure, anaesthesia and post-surgery analgesia were carried out by a trained technician. Briefly an incision was made on the right knee joint 
medially and proximally to the patellar tendon of 8-week-old DBA WT male mice $(\mathrm{N}=3)$. The patella was laterally dislocated and the joint fully flexed exposing the femoral retropatellar groove. A $25 \mathrm{G}$ needle was placed in the centre of the groove and dragged across its entire length repeatedly, trying to scratch the same line as previously described. ${ }^{(23)}$ Mouse were killed 3 days post-surgery.

\section{RNAscope ${ }^{\circledR}$ for articular cartilage}

Sample preparation

Mice were killed and knee collected three days post injury. Excess of muscle tissue was removed. Knees were immediately fixed after dissection in 4\% freshly prepared ice-cold RNAse-Free paraformaldehyde (PFA), for 24 hours at $4^{\circ} \mathrm{C}$ on a tube roller. After washing samples (PBS: $3 \times 5 \mathrm{~min}$, rotating at $4^{\circ} \mathrm{C}$ ), increasing sucrose gradient was applied (10\%, 20\% and 30\%) in PBS $1 \mathrm{X}$ for 24 hours or overnight $\left(\approx 16\right.$ hours) rotating at $4^{\circ} \mathrm{C}$ each gradient. Joints were embedded in Super Cryo Embedding Medium (Section lab, Japan) at $90^{\circ}$ with tibia facing down and stored at $80^{\circ} \mathrm{C}$. Figure 3 shows the correct sample orientation by growth plates morphology, for cryo-sectioning.

Samples were cryo-sectioned $(10 \mu \mathrm{m})$ using the Kawamoto's tape method (Section lab, Japan) (Figure 2). Briefly, a specific tape was glued and pressed over the sample. This method improves the integrity of tissue morphology after sectioning, especially for hard tissues as bone. The tape was then fixed over a slide using thermo resistant stickers. The slide was either stored at $-80^{\circ} \mathrm{C}$ or proceeded to target retrieval protocol.

\section{Target Retrieval}

Slides were washed in ice-cold PBS (5 minutes) and baked at $60^{\circ} \mathrm{C}$ (30 minutes). Samples were re-fixed with ice-cold 4\% PFA (15 minutes) and an increasing ethanol gradient was applied (50\%, 70\%, 100\% and 100\%) for 5 minutes each gradient. Samples were air dried for 5 minutes and then covered with hydrogen peroxide for 10 minutes. After washing in $\mathrm{dH}_{2} \mathrm{O}$, slides were pre-warmed in $\mathrm{dH}_{2} \mathrm{O}$ at $75^{\circ} \mathrm{C}$ (10 seconds) and transferred into Target Retrieval Buffer (1X) at $75^{\circ} \mathrm{C}$ in a steamer for $10 \mathrm{~min}$, finishing at $90-95^{\circ} \mathrm{C}$. Then, slides were rinsed in $\mathrm{dH}_{2} \mathrm{O}$, submerged in $100 \%$ ethanol and left at room temperature (RT) to dry. A barrier was created around samples with a histology hydrophobic pen. 
RNAScope® protocol

When the hydrophobic barrier dried, samples were covered with Protease III and incubate at $40^{\circ} \mathrm{C}$ in the $\mathrm{HybEZ}^{\mathrm{TM}}$ Oven (ACDBio $\left.{ }^{\circledR}\right)$ for 30 minutes and rinsed two times in $\mathrm{dH}_{2} \mathrm{O}$. Protocol continues in "Chapter 4. RNAscope ${ }^{\circledR}$ Multiplex Fluorescent v2 Assay". The negative and positive control genes were DapB (dihydrodipicolinate reductase) and Ppib (Peptidyl-prolyl cis-trans isomerase B), respectively. Target genes were TGF- $\beta$ R3 (Transform growth factor beta receptor 3) and FGFR3 (Fibroblast growth factor receptor 3). All genes were designed in channel one (C1), hence, they were stained individually in consecutive sections. RNAScope ${ }^{\circledR}$ protocol was carried out up to HRP-C1 and HRP Blocker. Samples were stained with $\mathrm{Opal}^{\mathrm{TM}} 620$, counter stained with DAPI (ThermoFisher ${ }^{\circledR}$ ) and coverslip mounted with Prolong Gold Antifade DAPI (ThermoFisher®).

\section{Confocal Microscopy}

In order to detect RNA copies (dots) it is necessary to use at least 20x lenses. The higher the lens, the higher the number of dots detected. In addition to the microscope amplification, epifluorescence signals also interfere with the amount of signal detected. As the RNA dots are extremely small, the focus plan (depth) of the sample also changes the spatial localization of dots. Therefore, using Z-stack is mandatory to accurately identify the target gene expression across the sample. The number of stacks, distance between stacks and the position of the first stack were set across all samples.

All images were obtained by the confocal microscope ZEISS LSM 880 operated by Zeiss Zen 2.3 software. For the knee samples of the focal defect model, 11 stacks were standardized, across the $Z$ axis, starting from the middle of the sample and collecting another five stacks upwards and downwards. The distance between stacks was defined by $5 \%$ penetration overlap of DAPI staining. The Table below shows other parameters used. To amplify the field of view, tilling of multiple images was used without overlapping or stitching tiles. All images were analysed by Image $\mathrm{J}$ software. 
Table 4. Confocal microscopy Zeiss Zen 2.3 software imaging settings

\begin{tabular}{|l|c|c|}
\hline Lens (medium) & 20x (air) & 40x (oil) \\
\hline DAPI laser (range) & $405 \mathrm{~nm}(410-581 \mathrm{~nm})$ & $405 \mathrm{~nm}(410-581 \mathrm{~nm})$ \\
\hline Opal® 620 laser (range) & $561 \mathrm{~nm}(588-624 \mathrm{~nm})$ & $561 \mathrm{~nm}(588-624 \mathrm{~nm})$ \\
\hline Pinhole & $1 \mathrm{AU}$ & $1 \mathrm{AU}$ \\
\hline Total Image Size & $6144 \times 8191$ pixels & $2048 \times 8192 \mathrm{pixels}$ \\
\hline Resolution & $4.8177 \mathrm{pixel} / \mu \mathrm{m}$ & $6.7488 \mathrm{pixel} / \mu \mathrm{m}$ \\
\hline Image depth (stacks) & $\approx 1 \mu \mathrm{m}(1)$ & $8.69 \mu \mathrm{m}(11)$ \\
\hline bit depth & 16 & 16 \\
\hline Tiles & $3 \times 4$ & $1 \times 4$ \\
\hline
\end{tabular}

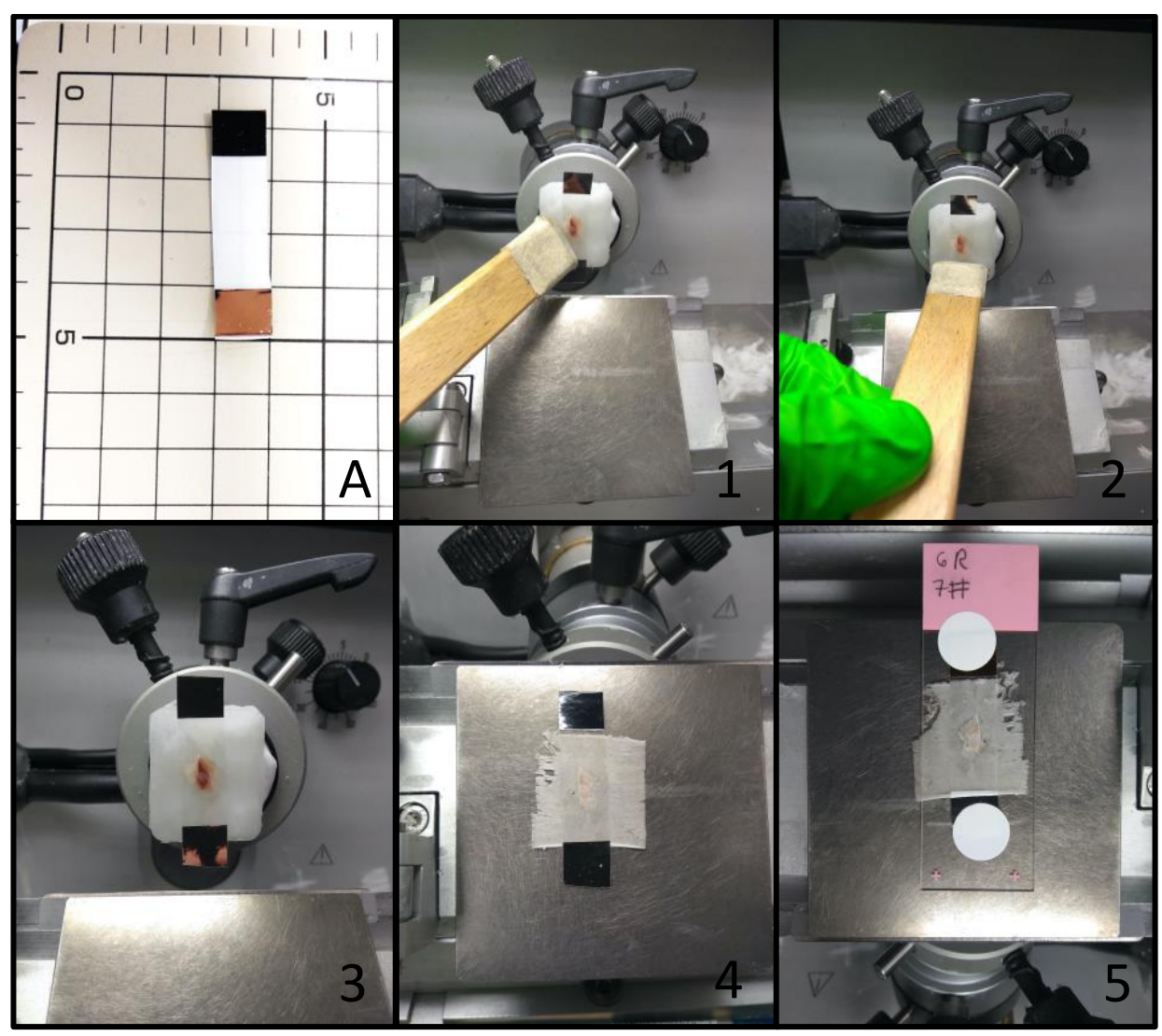

Figure 2. Kawamoto tape method. A- pre-cut tape. 1-2: pressing tape over the sample; 3: glued tape; 4: $10 \mu \mathrm{m}$ section facing down; 5: 10 $\mathrm{m}$ section facing up and tape fixed on the slide 


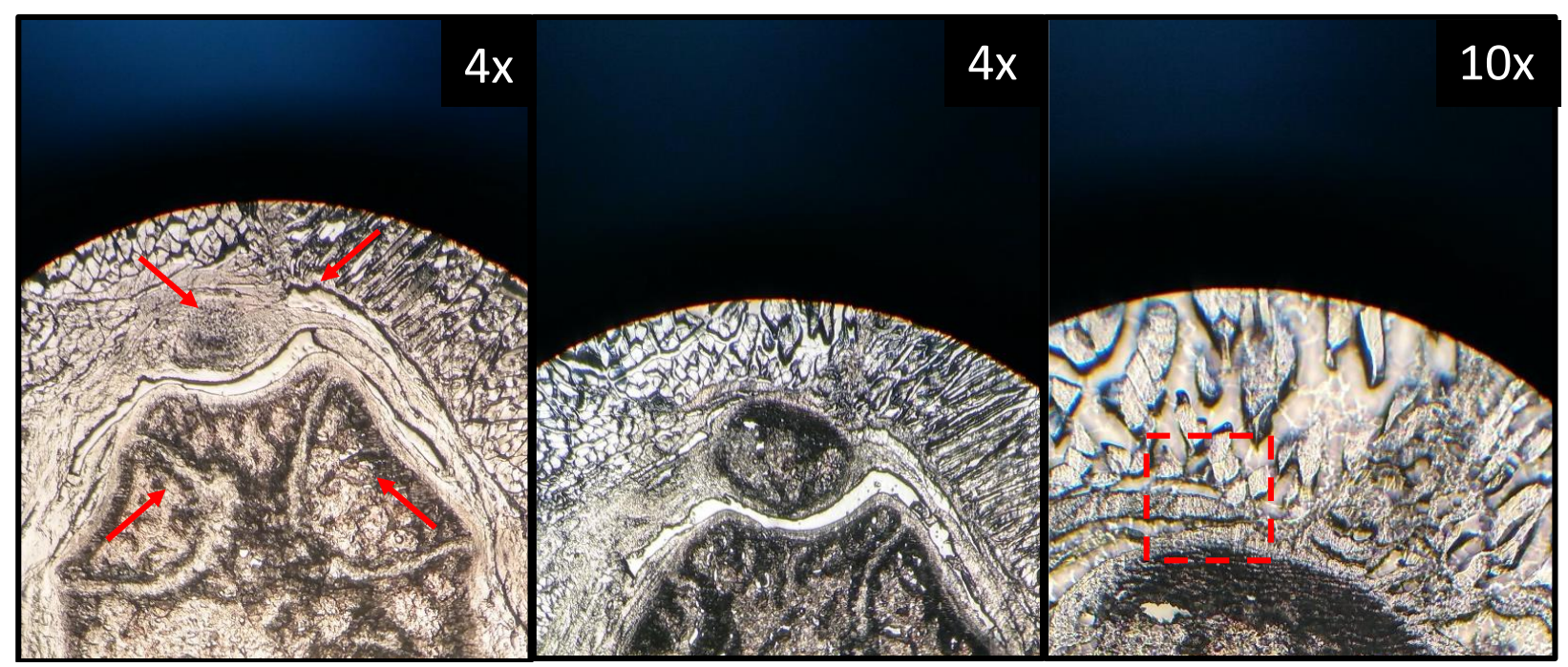

Figure 3. Bright field histology sections from knee cartilage of the scarification mouse model, three days post injury. Red arrows: Growth plates morphology indicative of correct positioning to evaluate the cartilage injury. Red dashed square: injury site.

\section{Statistical analysis}

For gene expression analysis between different conditions, ANOVA one way with Fisher or Tukey's post hoc tests were used for comparisons of three or four means, respectively. ANOVA two way with Tukey's post hoc was used for the analysis between groups (non-treated $\times$ treated) overtime $(0 \times 2 \times 4 \times 8 \times 24 \times 48$ hours). 


\section{MAIN RESULTS}

Figure 4 shows mAT-MSCs at seven days post isolation and after the first culture passaging. Figure 5 shows pChondro at 48 hours after isolation.

mAT-MSCs (P1)

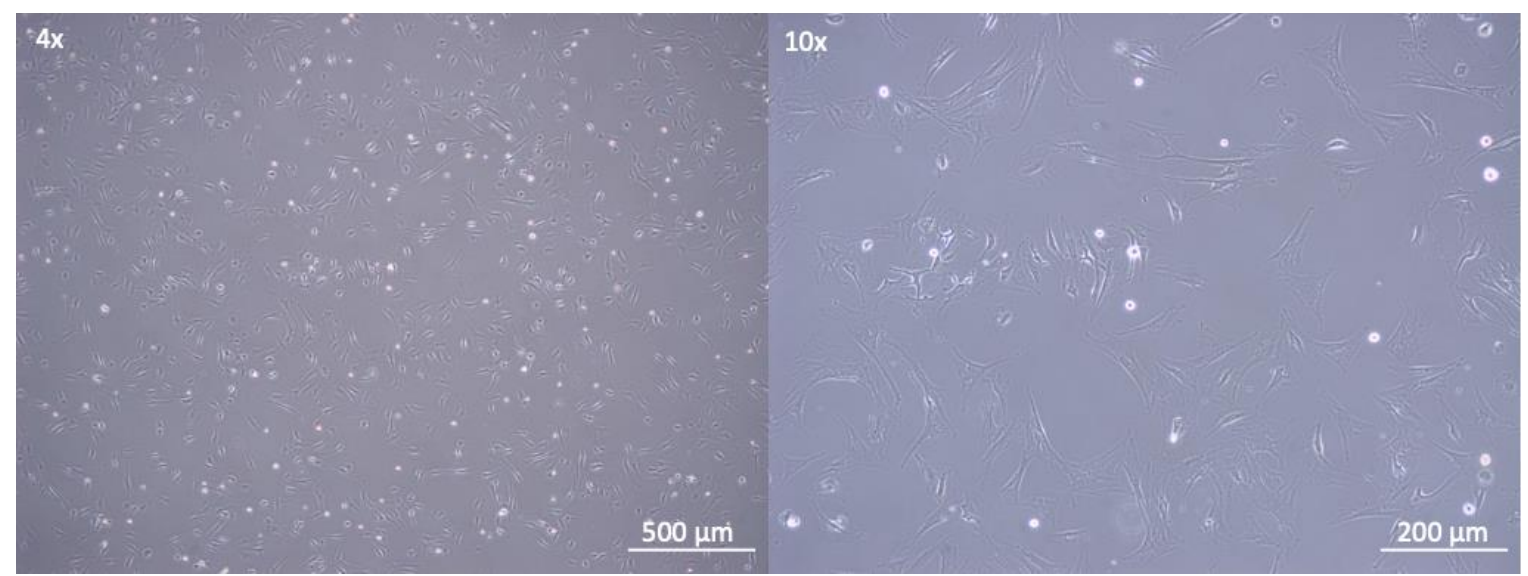

Figure 4. Adipose tissue mesenchymal stem cells clusters, from mice epididymal fat pad, seven days post isolation first culture passaging. Mice were six-week-old male Wild Type C57BL/6 (N=3). P1: first cell culture passaging.

pChondro

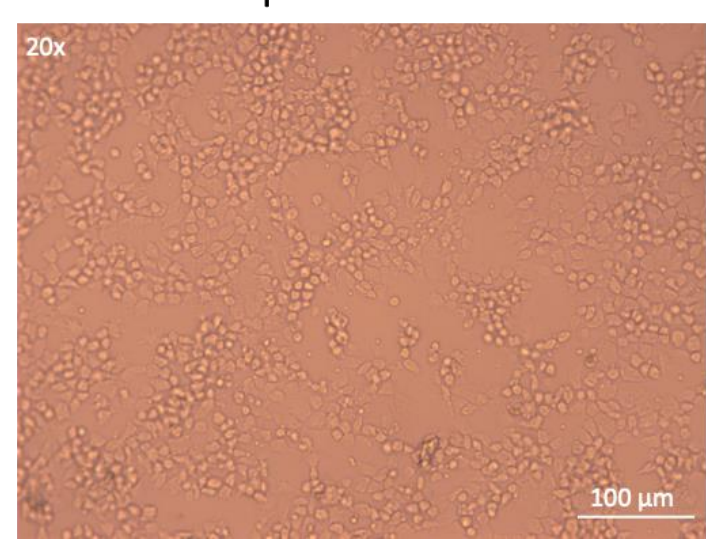

Figure 5. Primary chondrocytes, from porcine trotter's metacarpophalangeal (MCP) joint, 48 hours after isolation. $(\mathrm{N}=1)$

Previous experiments from Vincent's group showed upregulation of TGF- $\beta$ R3 (Betaglycan) expression after 24h of mAT-MSCs stimulation with FGF2. In order to find out the time course effect of this growth factor on TGF- $\beta$ R3 gene regulation, we analysed the effect of FGF2 stimulation from $0 \mathrm{~h}$ to $48 \mathrm{~h}(0,2,4,8,24,48$ hours) on mAT-MSCs. TGF- $\beta$ R3 gene expression increased after 24 and 48 hours without any stimulation, mainly due to reduction of housekeeping control gene expression (ACTB Ct values 0h, 48h: 15,18 respectively). This could be the effect of a 
prolonged culturing time without FBS. However, when stimulated with FGF2 there was a significant increase in gene expression of TGF- $\beta$ R3 regardless of housekeeping changes, especially at $48 \mathrm{~h}$ (Figure $6 \mathrm{~A}$ and $\mathrm{C}$ ).

Taking into consideration that during cartilage injury, cells are exposed not only to FGF2 but also Latent TGF- $\beta$ (REFERENCE, Tang paper), we analysed the effect of TGF- $\beta 3$ stimulation on MAT-MSCs overtime as well. As shown by Figure $6 \mathrm{~B}$ and D, TGF- $\beta 3$ has the opposite effect of FGF2; downregulating the expression of TGF- $\beta$ R3 at 24 and $48 \mathrm{~h}$. 
A

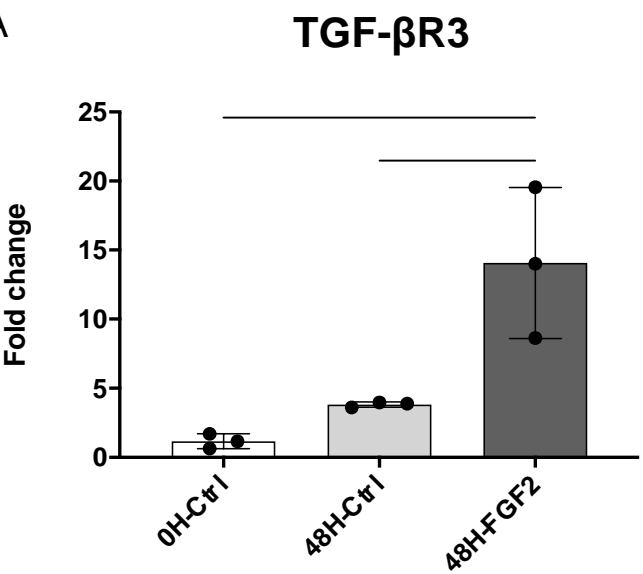

B

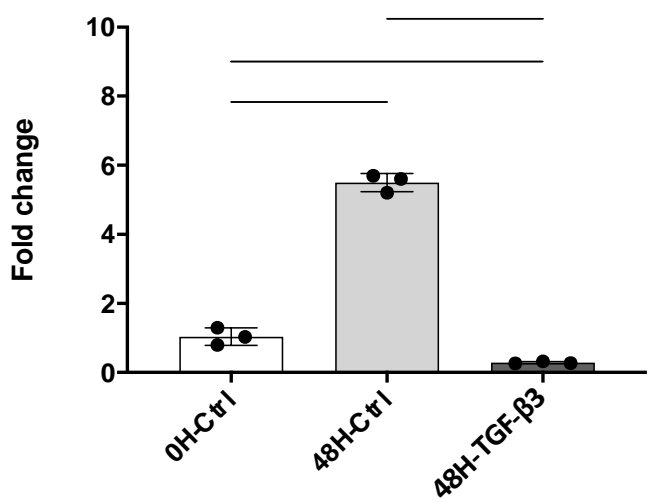

C

TGF- $\beta R 3$

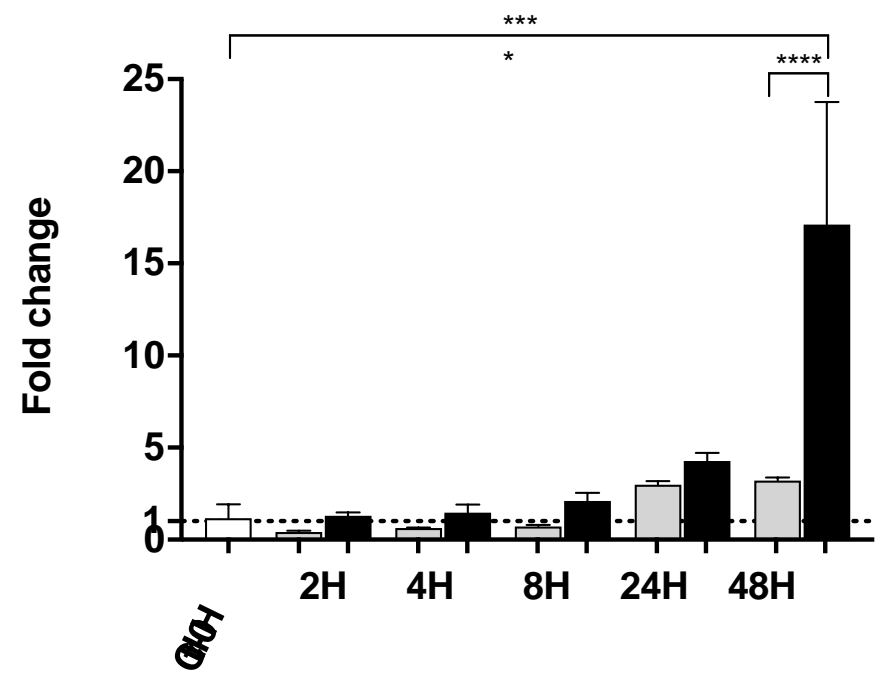

Non-treated

- FGF2-treated

$\mathrm{D}$

TGF- $\beta$ R3

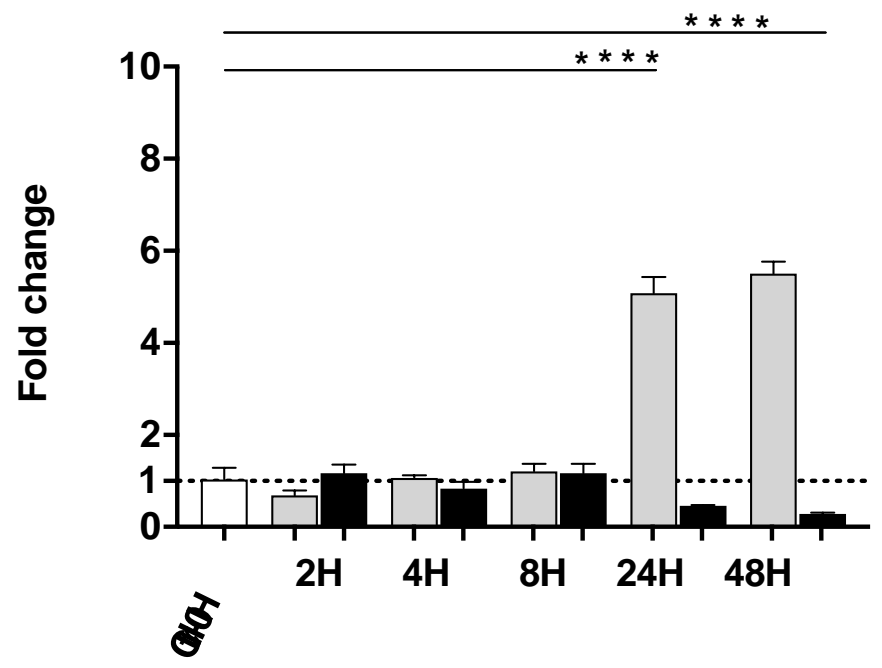

Figure 6.TGF- $\beta$ R3 (Betaglycan) gene expression in relation to zero-hour control (Ctrl-0H), overtime, for adipose tissue derived mesenchymal (mAT-MSCs) stimulated with FGF2 and TFG $\beta 3$. Reference gene: ACTB; * $p \leq 0,05 ;{ }^{* * *} p \leq 0,001 ;{ }^{* * * *} p \leq 0,0001$ 
Fibroblast Growth Factor Receptors (FGFRs) 1, 2 and 3 gene expression were also evaluated to check if they play a role in this opposing response of TGF- $\beta$ R3to FGF2 and TGF- $\beta 3$. FGFR1 and FGFR2 showed opposite regulation responses to both stimuli (Figure 7). Despite these changes, FGFR3 was not significantly regulated and the chondrogenic anabolic ratio FGFR3/FGFR1 ${ }^{(17)}$ was not altered.
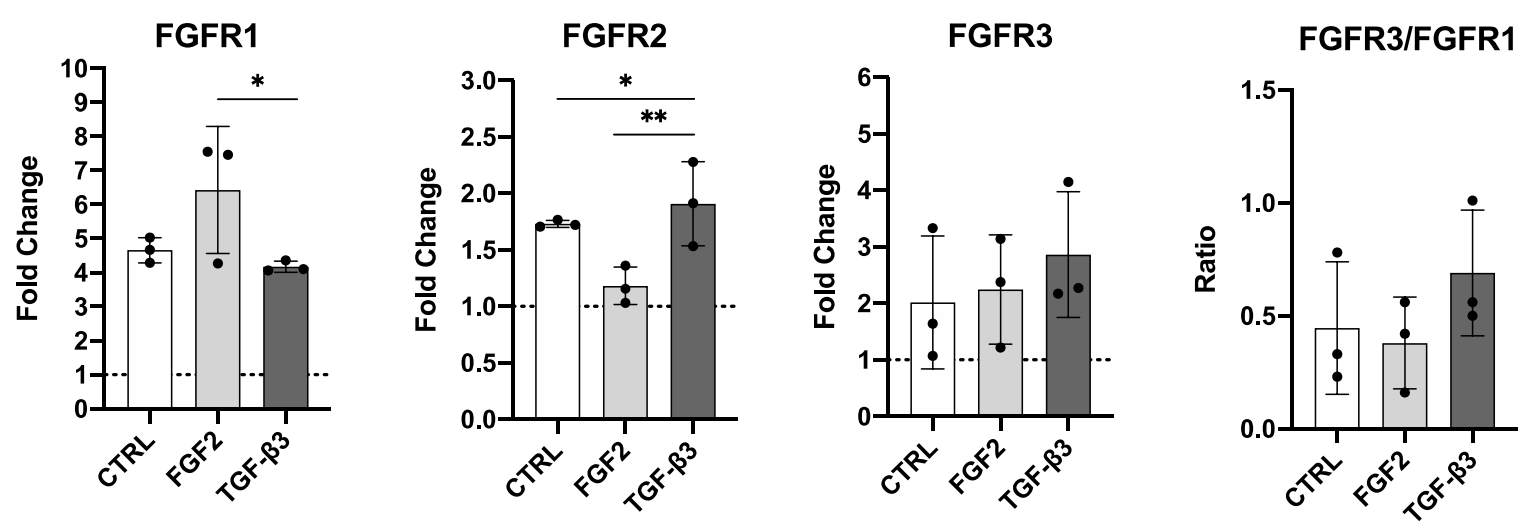

Figure 7. Gene expression of Fibroblast Growth Factor Receptors for adipose tissue derived mesenchymal (mAT-MSCs) 48 hours after stimulation with FGF2 and TFGß3. Data expressed in relation to zero-hour control (dotted line). Reference gene: GAPDH; * $p \leq 0,05 ;{ }^{* *} p \leq 0,01$;

Taking into consideration that we observed the highest gene expression changes after 48 hours, the following experiments were also performed over the same time span. After analysing mAT-MSCs responses to FGF2 and TGF- $\beta 3$ stimulation, we proceeded to evaluate the effect of FGF2 stimulation and FGFRs inhibition (FGFRi) on pChondro. Interestingly, FGF2 does not up regulate TGF- $\beta$ R3 expression after $48 \mathrm{~h}$ in this cell type (Figure 8). Chondrogenic genes increased their expression in the presence of FGFRi when compared to FGF2 stimulation. Unlike MSCs, he regulation of FGFRs in pChondro demonstrated a down-regulation of FGFR3 and increase in FGFR1 upon FGF2 stimulation. Furthermore, cells exposed to FGFRi showed higher FGFR3 expression and FGFR3/FGFR1 ratio compared to FGF2 stimulation. Changes in gene expression after FGFRi exposure alone, without adding exogenous FGF2, might be due to inhibition of endogenous FGF2 released into the extracellular environment during the experiment. 

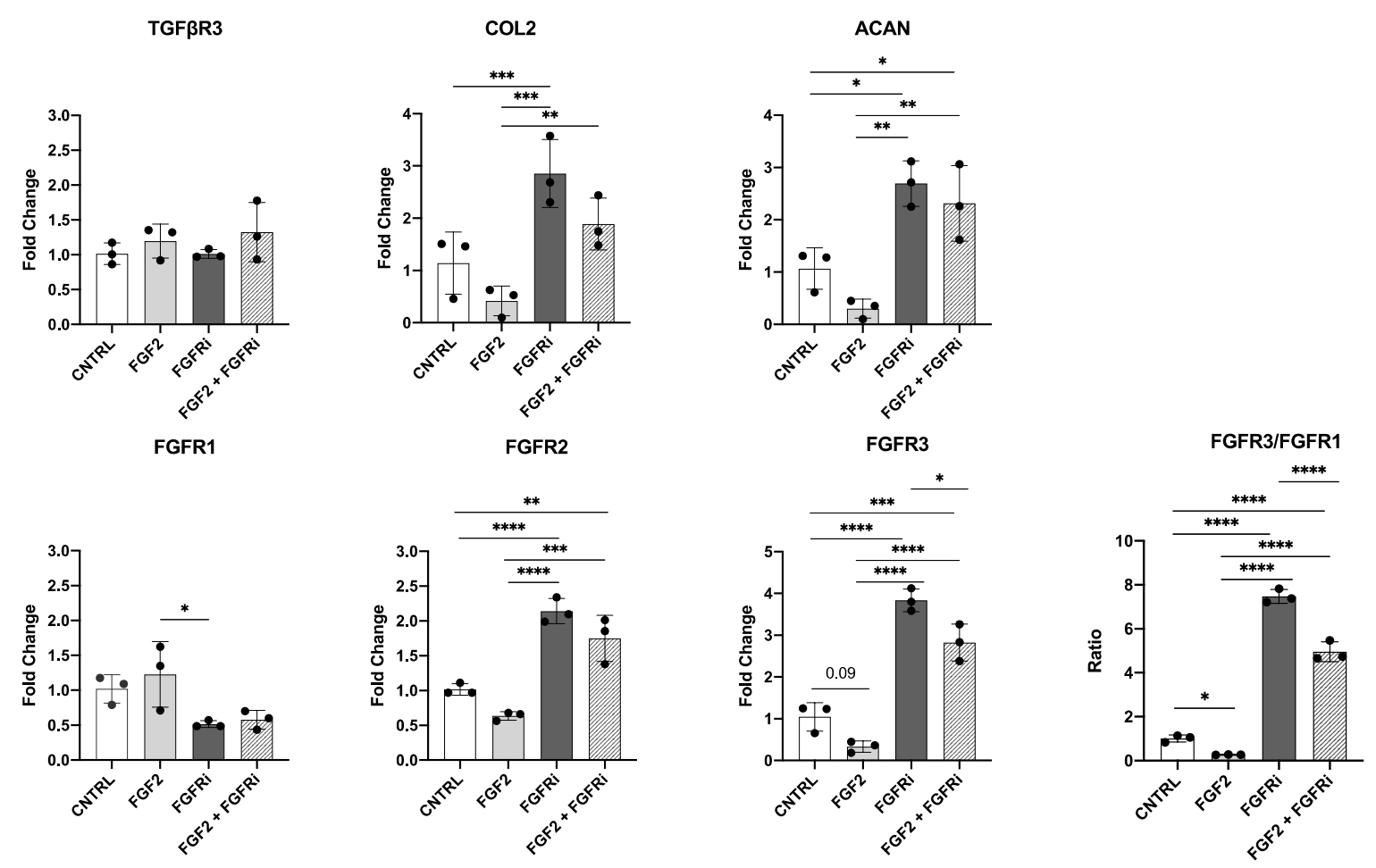

Figure 8. Gene expression ofTGF- $\beta$ R3, Fibroblast Growth Factor Receptors (FGFRs), Type II Collagen and Aggrecan, 48h hours after porcine primary chondrocytes stimulation (FGF2) and inhibition (FGFRi) of FGFRs. Data expressed in relation to 48 -hour control (CTRL). Reference gene: $18 S ;{ }^{*} p \leq 0,05 ;{ }^{* *} p \leq 0,01$; ${ }^{* * *} p \leq 0,001 ;{ }^{* * * *} p \leq 0,0001$

However, inside the articular joint environment, cartilage injury releases both FGF2 and TGF- $\beta$ in its latent form. ${ }^{(18)}$ To evaluate the presence of both growth factors simultaneously and their effect on mAT-MSCs and pChondro, cartilage injury conditioned medium (injury CM) was used to stimulate cells directly.

For gene expression regulation, for pChondro, TGF- $\beta$ R3 was not regulated by injury CM (Figure $11 \mathrm{~B}$ ). However, injury CM reduced FGFR3/FGFR1 ratio by upregulating FGFR1 and downregulating FGFR3 compared to control. This was largely reversed in the presence of the FGFRi. Along with FGFR3/FGFR1 ratio, COL2 and ACAN also increased. These gene expression patterns are similar to our previous experiment (Figure 8), where pChondro were treated with FGF2 or FGFRi, and indicating FGF2 as an important chondrogenic suppressor of chondrogenesis in this context.

For mAT-MSCs, the response to injury CM was not the same as when cells were treated with recombinant FGF2 and FGFRi. Both $\mathrm{CM}$ and $\mathrm{CM}+\mathrm{FGFRi}$ downregulated TGF- $\beta$ R3 and induced expression of COL2. However, in the presence of 
FGFRi, the expression of COL2 caused by CM was lower. CM+FGFRi induced mATMSCs gene expression responses similar to TGF- $\beta 3$ stimulation, downregulating FGFR1 and upregulating FGFR2. The CM alone, downregulated FGFR1 and upregulated FGFR3 increasing the FGFR3/FGFR1 ratio. It seems that in the case of CM stimulation, mAT-MSCs does not benefit from FGFRi in terms of chondrogenic signalling. On the contrary, the action of fibroblast growth factors (e.g. FGF2) boosts this signalling.

Considering that, TGF- $\beta$ R3 is responsible for releasing TGF- $\beta$, from its latent complex to its active form and FGF2 increases the activity of TGF- $\beta$ R3, it was possible that simultaneous presence of different growth factors in the conditioning medium, could have synergistically interacted. In that sense, we suspected that FGF2primedmAT-MSCs by increasing TGF- $\beta$ R3 expression which would lead to a subsequent increase in TGF- $\beta$ bioavailability. Consequently, during the time course of 48 hours, as TGF- $\beta$ concentration increases it downregulates TGF- $\beta$ R3 expression and increases chondrogenic signalling. 
A
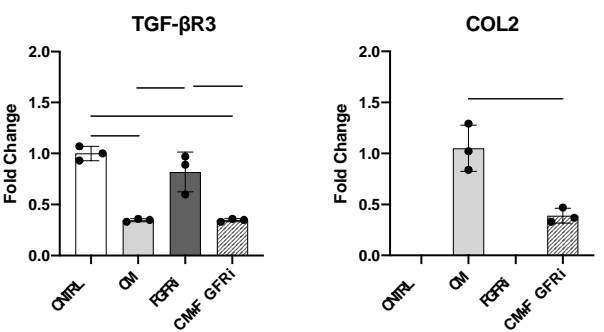

mAT-MSCs
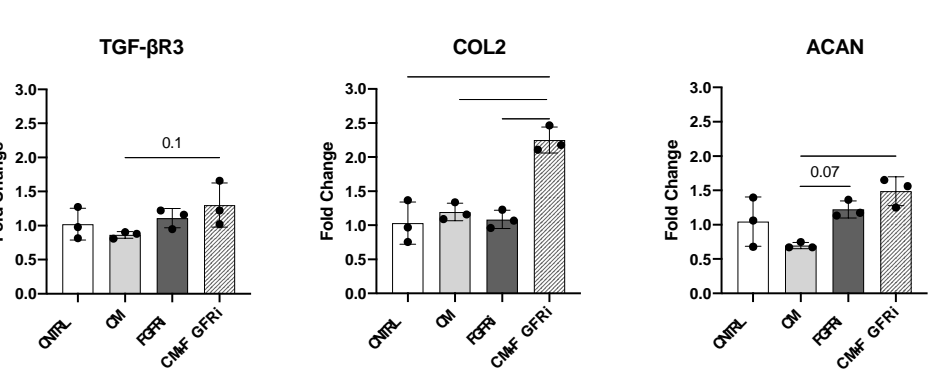

C FGFR1

FGFR2

FGFR3

FGFR3/FGFR1

mAT-MSCs
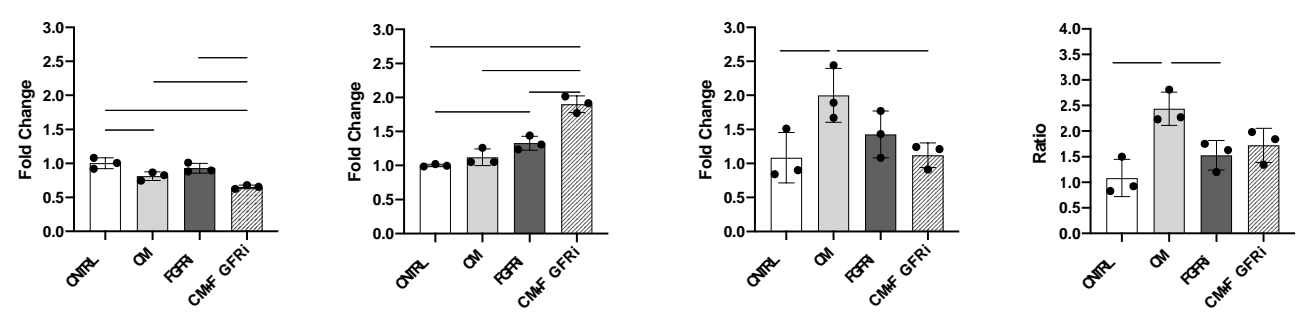

$\mathrm{D}$

pChondro
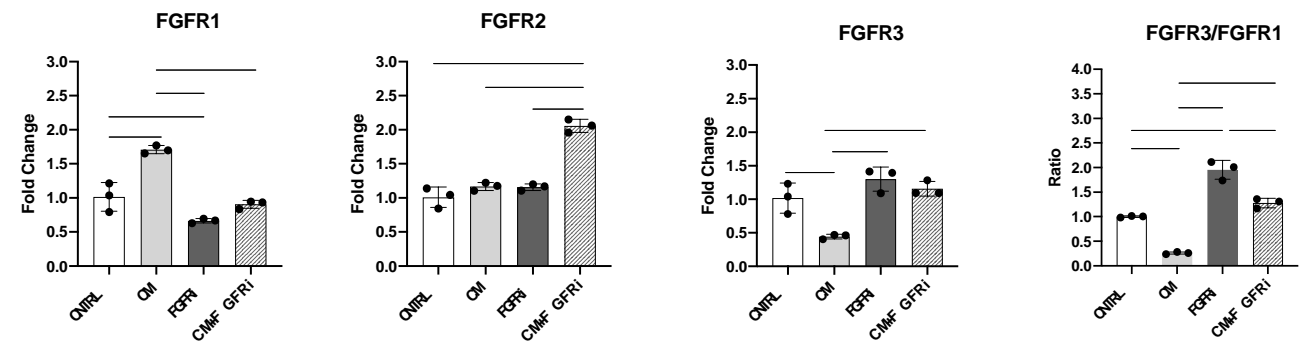

Figure 9. Opposite effect of cartilage injury conditioning medium (CM) over mouse adipose tissue mesenchymal stem cells (mAT-MSCs) and porcine chondrocytes (pChondro), after 48 hours stimulation. A-B: TGF- $\beta R 3$ and chondrogenic related genes; C-D: Fibroblast Growth Factor Receptors (FGFR1, FGFR2, FGFR3) gene expression and ratio; FGFRi: Fibroblast Growth Factor Receptor inhibitor; mAT-MSCs reference gene: ACTB; pChondro reference gene: $18 \mathrm{~S} ;{ }^{*} p \leq 0,05 ;{ }^{* *} p \leq 0,01 ;{ }^{* * *} p \leq 0,001 ;{ }^{* * * *}$ $\mathrm{p} \leq 0,0001$.

As FGF2 and CTGF-Latent TGF- $\beta$ are heparin-binding growth factors, which are both known to cause cell proliferation. ${ }^{(12,19,24)}$ We tested the direct effect of injury CM on mAT-MSCs, before and after passing it through an affinity column to deplete Heparin-binding Growth Factors (CM-HbGF-depl). We measured the total number of mAT-MSCs attached to the culture plate after 48 hours stimulation with injury 
CM or CM-HbGF-depl. Flow-through samples A5 and A6 were mixed together and used for the experiment as they expressed the highest protein content (Figure $10 \mathrm{~A}-\mathrm{B}$ ). Western Blotting showed that FGF2 (17kDa) and a non-specific band (23kDa) were present in the starting injury CM. FGF2 was depleted after passing through the column (Figure $10 \mathrm{C}$ ).

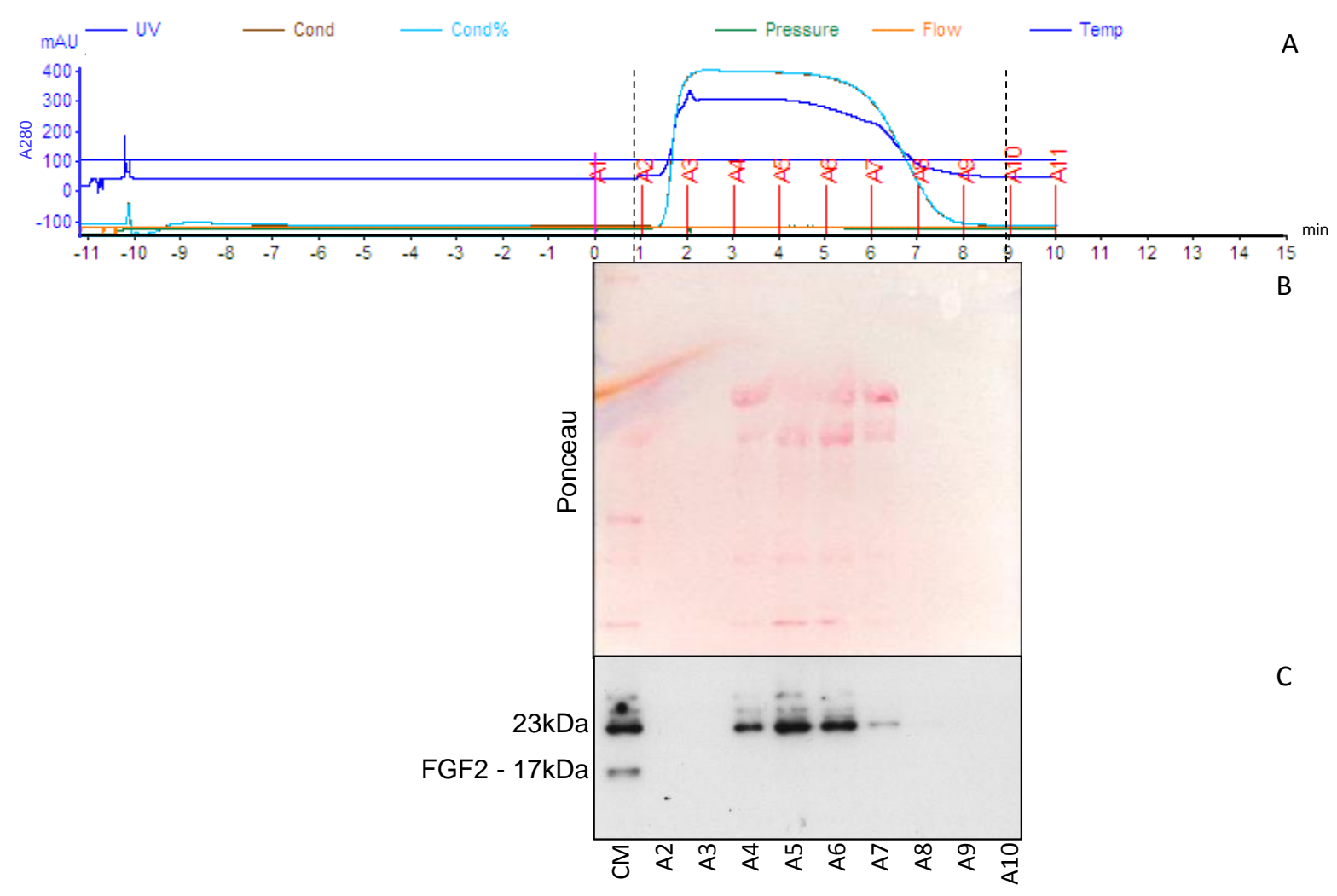

Figure 10. Heparin biding Growth Factors depletion (HbGF) of cartilage injury condition medium (CM). AChromatography of $\mathrm{CM}$ after HbGF column; B - Ponceau staining of samples protein content; C Western Blotting for fibroblast growth factor 2 (FGF2); A2-A10: HbGF depleted CM flow-through samples; UV: Ultraviolet light; Cond: Conductivity; Cond\%: Relative Conductivity; Temp: Temperature;

After 48 hours, CM increased cell proliferation of MSCs and this activity was lost after heparin column depletion. Despite the reduced proliferative capacity of CM-HbGF-depl, it maintained cell viability without reducing the total numbers of cells compared to $48 \mathrm{~h}$ control (Figure 11). The slight reduction of attached cell after 48h without stimulation, might be due to detachment by over confluence or cell death in the absence of FBS. This experiment indicated that HbGFs released upon cartilage injury, may play a key role in MSC proliferation early after injury. 


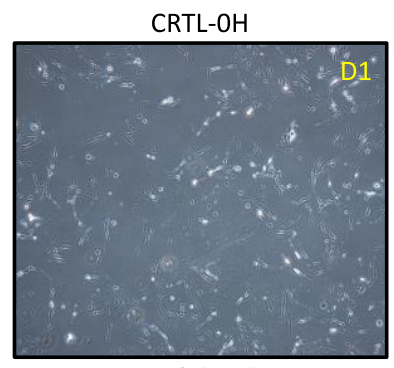

EVE $₫$ Cell Counter

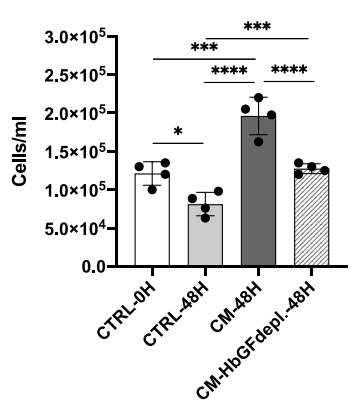

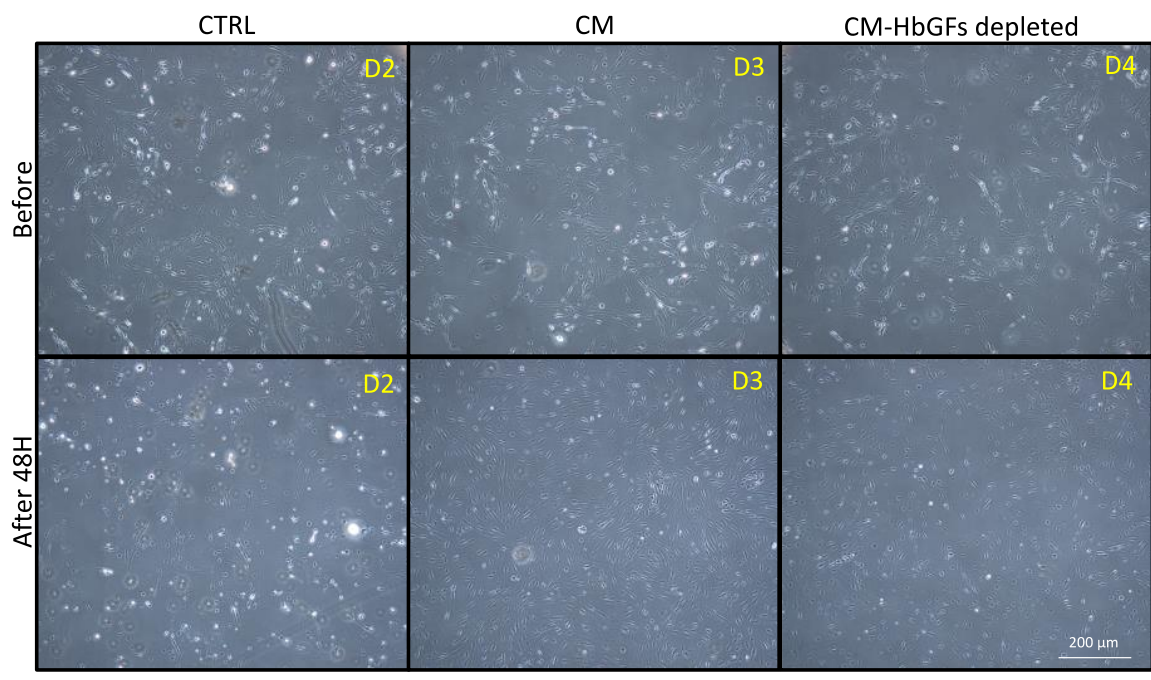

Figure 11. Cartilage injury conditioning (CM) and CM Heparin-biding Growth Factors depletion (CMHbGF-depl) effect on mouse adipose tissue mesenchymal stem cells proliferation after 48 hours (48H). CTRL-OH: zero-hour control wells; CTRL-48H: 48 hours control wells; D1-D4: culture plate wells identification; ${ }^{*} p \leq 0,05 ;{ }^{* * *} p \leq 0,001 ;{ }^{* * * *} p \leq 0,0001$.

To better understand the results from in vitro experiments we decided to check the ex-vivo spatial gene expression of Betaglycan and FGFR3, inside the joint, after an acute cartilage injury model. In order to do that, Professor Tonia Vincent gave me the opportunity and challenge to optimize the RNAScope ${ }^{\circledR}$ technology for articular cartilage. After the optimisation of a cryosectioning protocol for hard tissues, provided by Dr.Maria Dzamukova from Professor Max Löhning's lab, I was able to produce the first RNAScope ${ }^{\circledR}$ image of chondrocyte gene expression on mouse articular cartilage. To improve the imaging quality, we also introduced and optimized the use of confocal microscopy for these RNAScope ${ }^{\circledR}$ samples (Figure 12).

RNAScope ${ }^{\circledR}$ negative and positive control probes are standard gene probes, with the purpose of checking if the sample and reagents used during the protocol are working properly. These probes are not experimental controls. For the negative control, one dot (RNA copy) every 10 cells is "set" as background. For the positive control, ubiquitously expressed genes were predetermined for each probe channel and by the multiplex fluorescent kit as follows: Channel 1 - Peptidyl-prolyl cistrans isomerase B (Ppib); Channel 2 - RNA polymerase II subunit A (Polr2a); Channel 3: Ubiquitin $\mathrm{C}(\mathrm{UbC})$. The expression of Ppib is barely detectable in chondrocytes, but it is possible to confirm its expression on other cell types inside the joint, specially the 
synovial membrane (Figure 12). Articular cartilage chondrocytes are quiescent cells and naturally have lower gene expression activity; we observed that the amount of RNA copies in these cells were much lower when compared with cells of the synovial membrane, muscle or bone marrow.

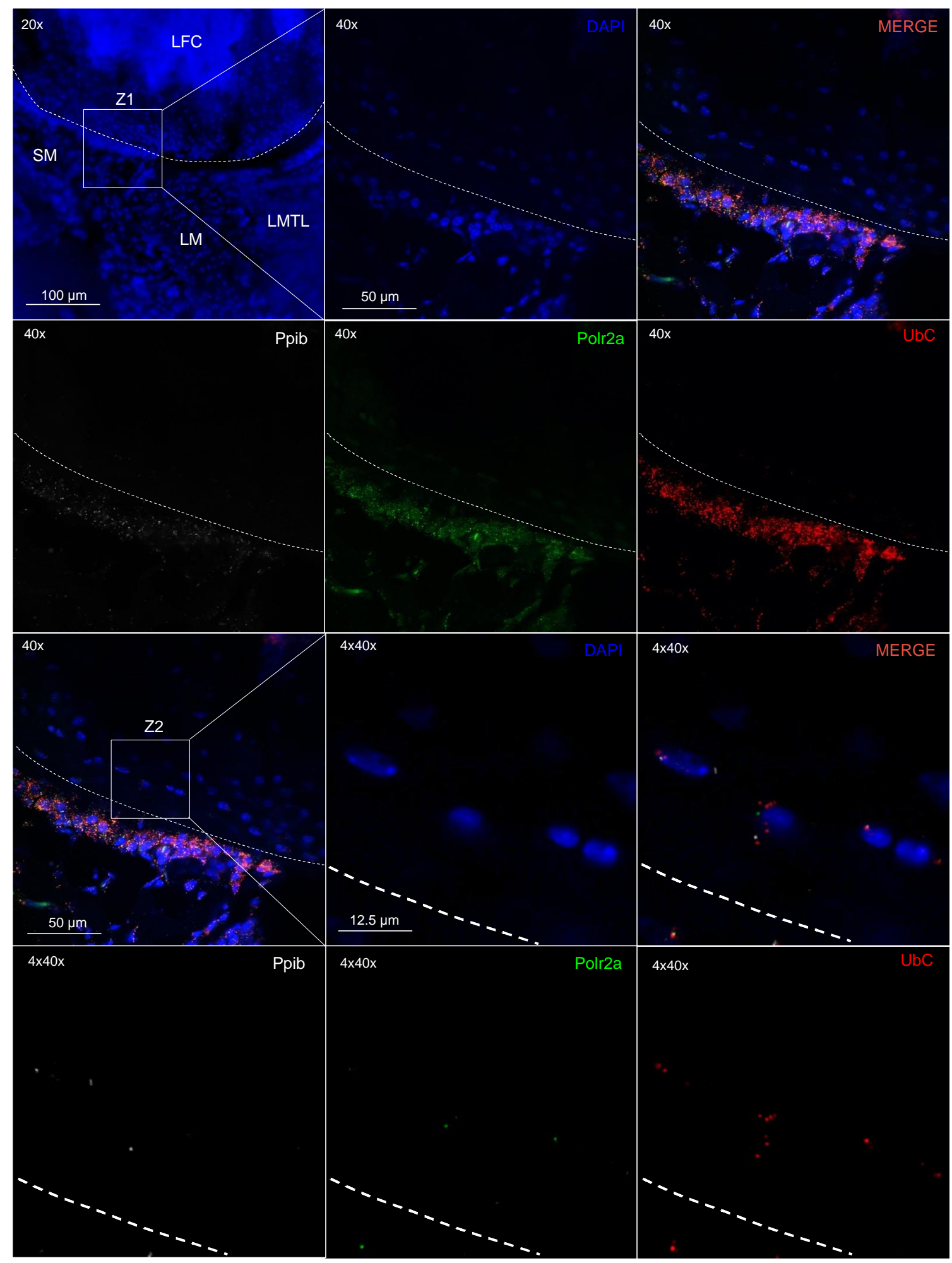


Figure 12. RNAScope® standardization for articular cartilage. Sample: health knee joint from male Wild Type C57BL/6 (N=1). Multiple Z-stacks (11) of positive control probes for Chanel 1 (Ppib): Peptidyl-prolyl cis-trans isomerase B; Chanel 2 (Polr2a): RNA polymerase II subunit A; Chanel 3 (UbC): Ubiquitin C; Blue counter staining (DAPI): cell nucleus. Z1: zoomed imaging field for 40x analysis. Z2: zoomed imaging field for four times digitally enlarged 40x analysis (4x40x). White dotted line: articular cartilage surface. LFC: Lateral Femoral Condyle; LMTL: Lateral Meniscotibial Ligament; LM: Lateral Meniscus; SM: Synovial Membrane.

The following images are the negative and positive probes. These images were obtained by combining multiple tiles, in order to better visualize the RNA copies (coloured dots). It was also necessary to digitally zoom in 5 times the original 20x image. As expected Ppib was highly expressed at the synovium, but not the cartilage.

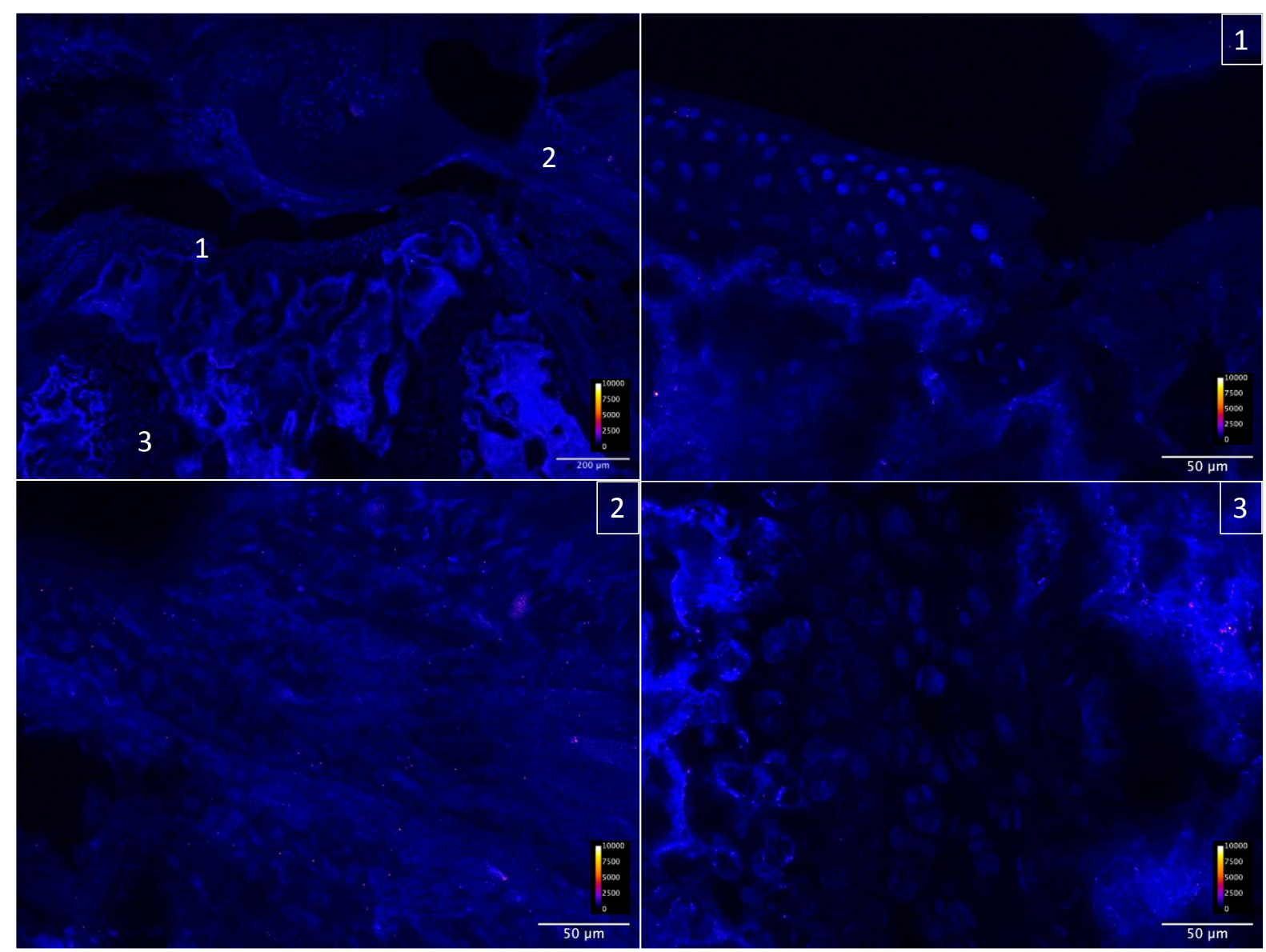

Figure 13.RNAScope® negative control dihydrodipicolinate reductase (DapB) bacterial gene expression. Top left image shows a 20x single stack picture, three days post injury of scarification mouse model. Images 1, 2 and 3 are five times digitally zoomed from specified locations. 1: articular cartilage and injury; 2: synovial membrane; 3: growth plate. Coloured dots (calibration bar): RNA copies in grey scale intensity; Blue counter staining (DAPI): cell nucleus. 


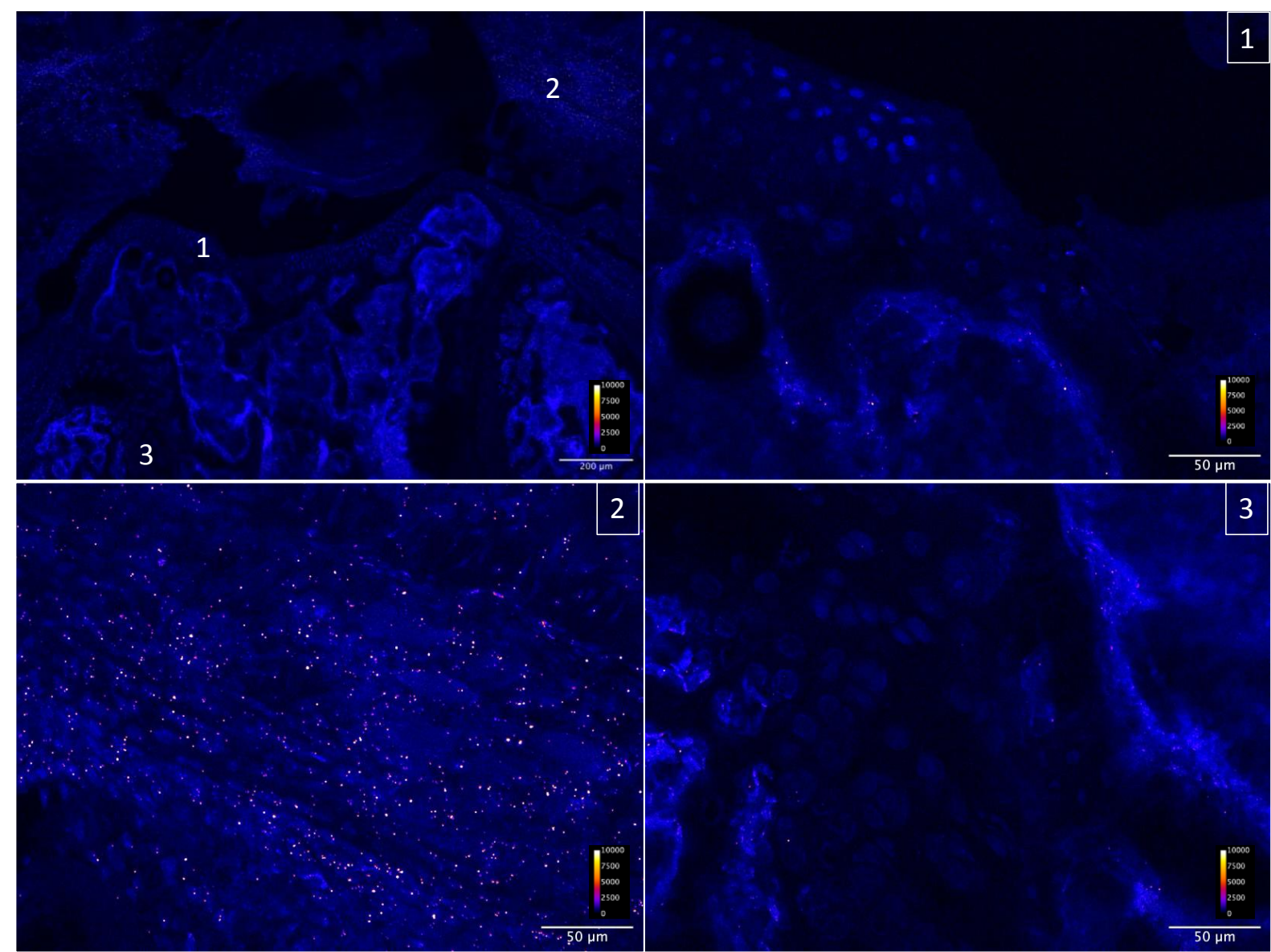

Figure 14.RNAScope ${ }^{\circledR}$ positive control Peptidyl-prolyl cis-trans isomerase B (Ppib) gene expression. Top left image shows a 20x single stack picture, three days post injury of scarification mouse model. Images 1, 2 and 3 are five times digitally zoomed from specified locations. 1: articular cartilage and injury; 2: synovial membrane; 3: growth plate. Coloured dots (calibration bar): RNA copies in grey scale intensity; Blue counter staining (DAPI): cell nucleus.

We found that the highest detection of TGF- $\beta$ R3was in the synovial membrane, followed by bone marrow and only few dots were apparent in articular chondrocytes (Figure 17 and 18). As for FGFR3, the expression level seemed to be similar on articular cartilage chondrocytes, bone marrow and synovial membrane cells (Figure 15 and 16). On synovial membrane, TGF- $\beta$ R3 expression was much higher than FGFR3, however, on articular cartilage FGFR3 expression was higher than TGF$\beta R 3$. Interestingly, as observed in consecutive cryosections slides, the FGFR3 and TGF- $\beta$ R3 expression on the injury site seemed to colocalize (arrows on Figure 16 and 18). 


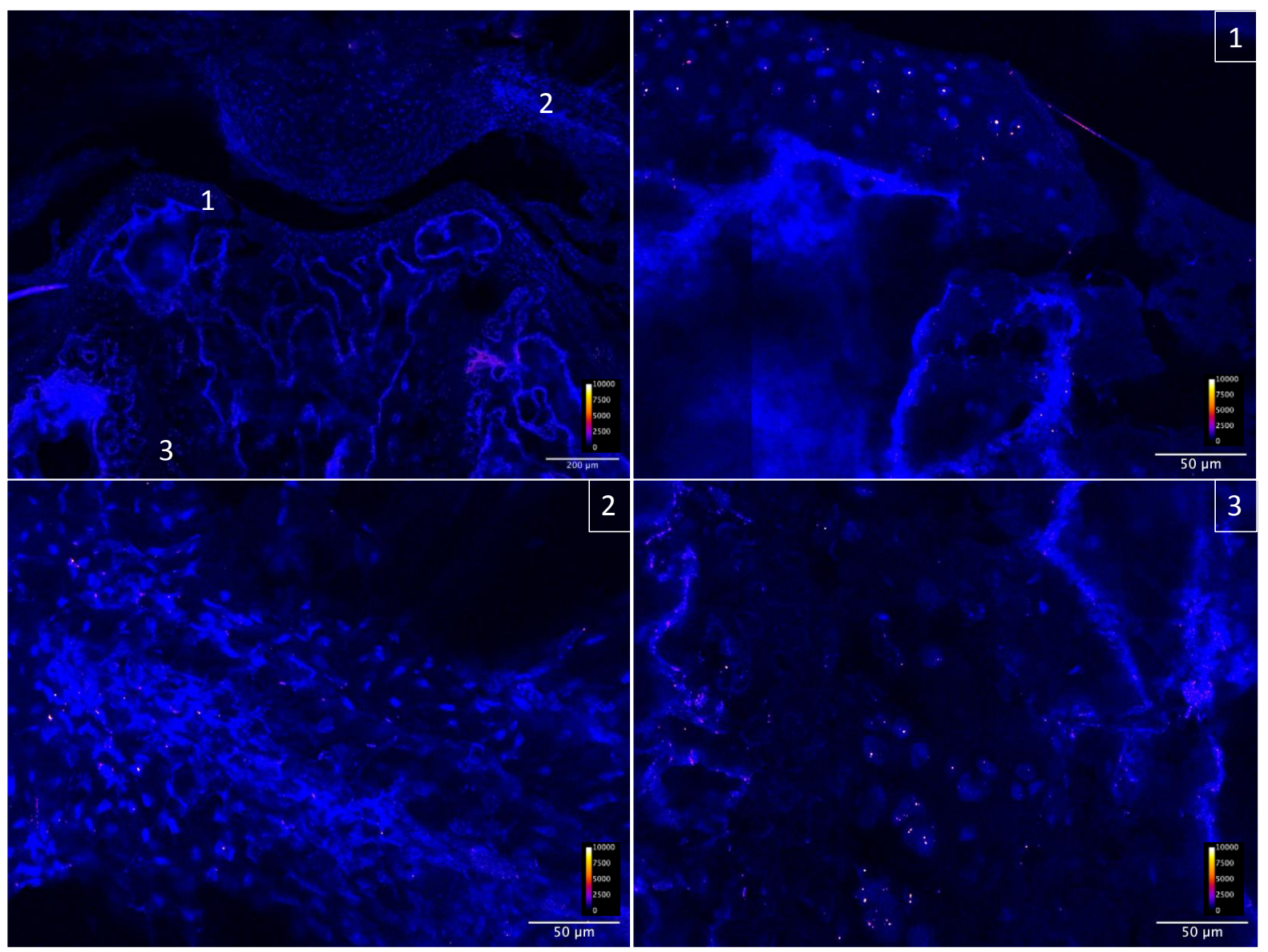

Figure 15.RNAScope ${ }^{\circledR}$ of fibroblast growth factor receptor 3 (FGFR3) gene expression. Top left image shows a 20x single stack picture, three days post injury of scarification mouse model. Images 1, 2 and 3 are five times digitally zoomed from specified locations. 1: articular cartilage and injury; 2: synovial membrane; 3: growth plate. Coloured dots (calibration bar): RNA copies in grey scale intensity; Blue counter staining (DAPI): cell nucleus. 


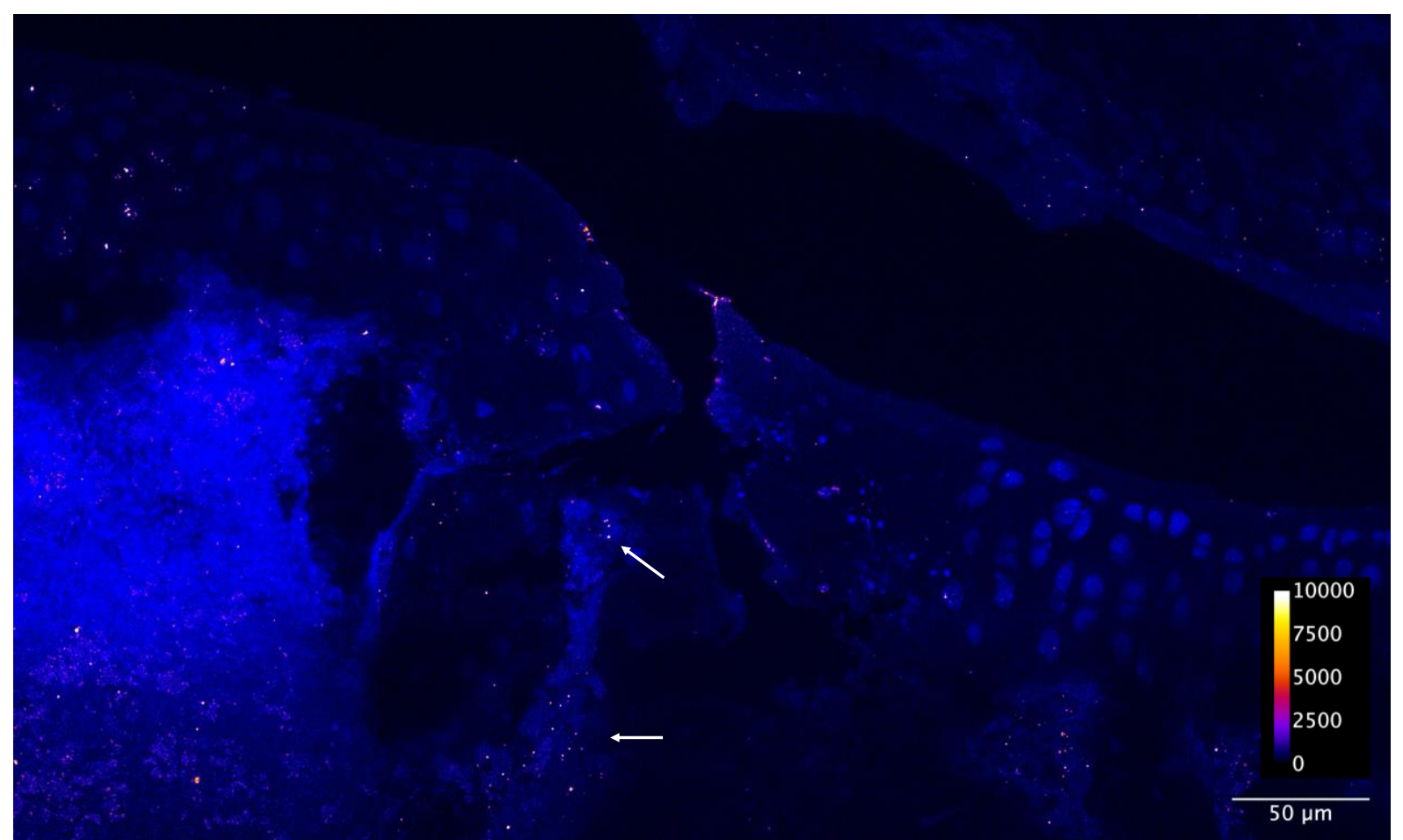

Figure 16. RNAScope ${ }^{\circledR}$ of fibroblast growth factor receptor 3 (FGFR3) gene expression. Image shows 11 merged stacks at $40 \mathrm{x}$, three days post injury of scarification mouse model. Coloured dots (calibration bar): RNA copies in grey scale intensity; Blue counter staining (DAPI): cell nucleus; White arrows: TGFBR3 RNA copies inside the injury. 


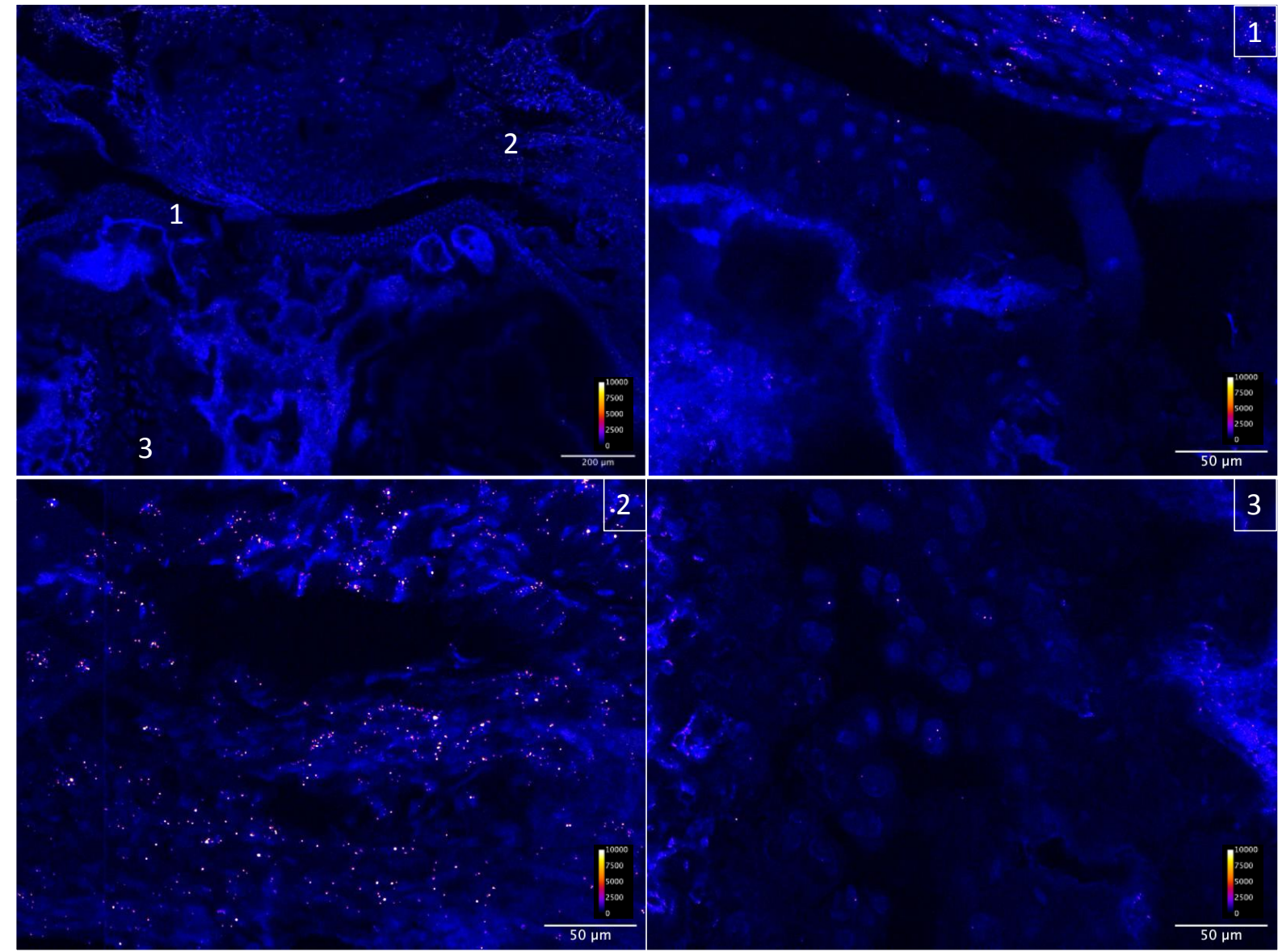

Figure 17.RNAScope ${ }^{\circledR}$ of transforming growth factor beta receptor 3 (TGF- $\beta$ R3) gene expression. Top left image shows a 20x single stack picture, three days post injury of scarification mouse model. Images 1, 2 and 3 are five times digitally zoomed from specified locations. 1: articular cartilage and injury; 2: synovial membrane; 3: growth plate. Coloured dots (calibration bar): RNA copies in grey scale intensity; Blue counter staining (DAPI): cell nucleus. 


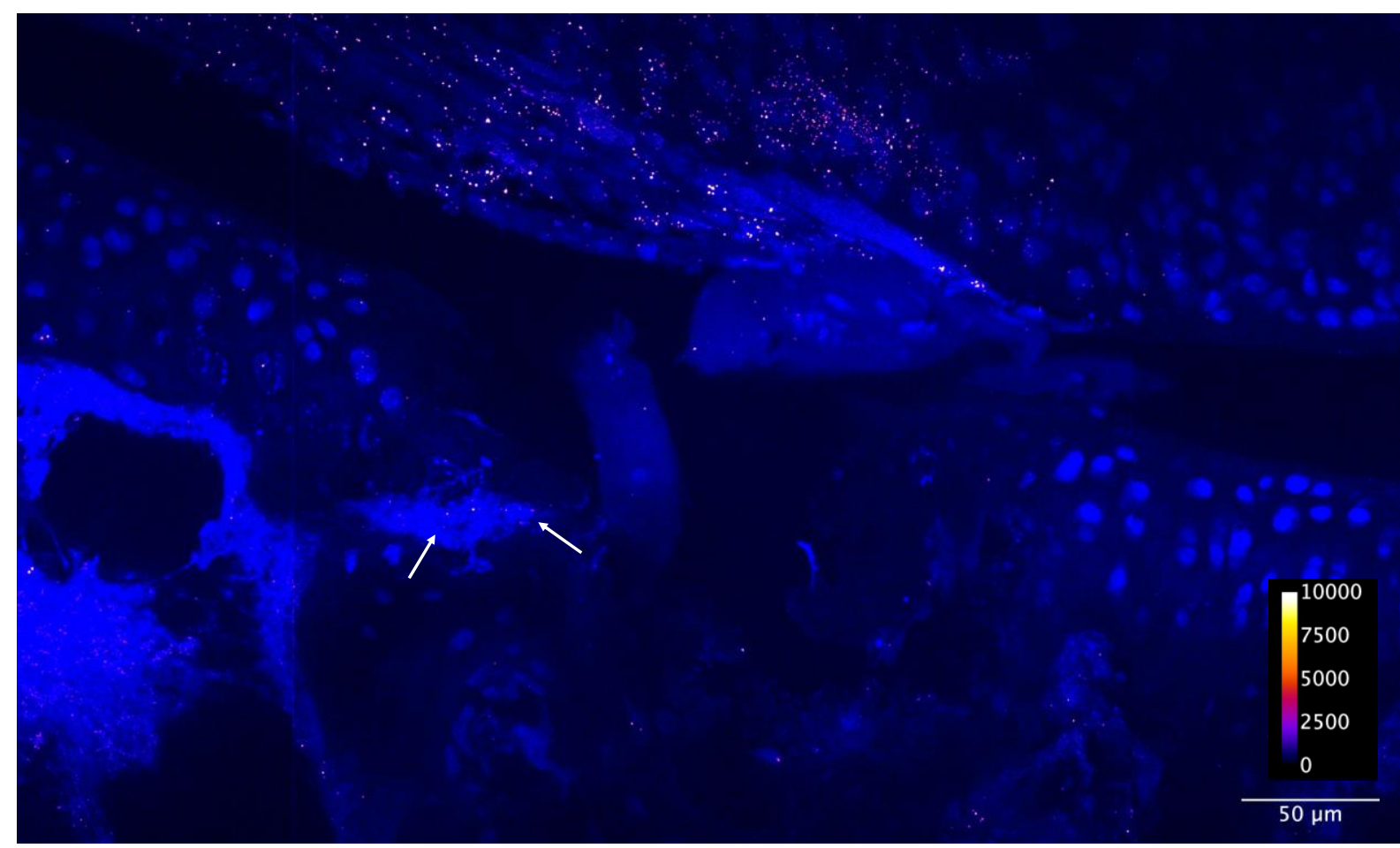

Figure 18. RNAScope ${ }^{\circledR}$ of transforming growth factor beta receptor 3 (TGF- $\beta$ R3) gene expression. Image shows 11 merged stacks at 40x, three days post injury of scarification mouse model. Coloured dots (calibration bar): RNA copies in grey scale intensity; Blue counter staining (DAPI): cell nucleus; White arrows: TGF- $\beta$ R3 RNA copies inside the injury.

\section{NEXT STEPS}

\section{Publication}

Data generate during my internship, together with other results obtained by Professor Vincent's group, are going to be part of a paper regarding the role of FGF2 in cartilage injury and repair.

\section{Complementary data}

Due to the COVID-19 pandemic, the University of Oxford and the NDORMS adopted preventive safety measures to reduce exposure of students and staff. Consequently, we were advised to finish on-going experiments and gradually reduce laboratory activities until the complete lockdown announcement. As it was my last month of internship, I was able to collect but not finish the experiments described below. These experiments will be completed by other members of Professor Vincent's group after the reestablishment of laboratory activity.

In order to better understand the interaction of FGF2 - LTGF- $\beta$ TGF- $\beta$ R3, I repeated the CM/FGFRi experiment, with mAT-MSCs, using the same 
conditions but this time I also used TGF- $\beta$ Receptor 1 inhibitor (TGF- $\beta$ R1i) (SB 431542). The inhibition of the canonical chondrogenic pathway TGF- $\beta R 1$ and TGF- $\beta R 2$, and the combination of FGFRi and TGF- $\beta$ R1i would help elucidate the priming effect of FGF2 on mAT-MSCs. The experiment was finished and the samples stored. RNA isolation and $\mathrm{QPCR}$ need to be carried out.

For the RNAScope ${ }^{\circledR}$ experiment, I have collected samples of 12 mice from 4 different groups ( $N=3 /$ group). Two groups were collected three days post cartilage injury scarification model and two groups seven days post injury. For each time point, groups were characterized as healer (DBA WT) and non-healer (DBA FGF2-KO), accordingly to the mouse strain and its ability to repair the cartilage injury, as observed previously by Professor Vincent's group (unpublish data). Using FGFR3 and TFG- $\beta$ R3 probes, the completion of these experiment would show if FGF2 Knockout mice has a different spatial distribution and expression of these genes after cartilage injury. Samples were processed, embedded and properly stored. Eight injured knees were cryo-sectioned with Kawamoto's tape and stored for RNAScope ${ }^{\circledR}$ staining.

\section{CONCLUSION}

Together, the present findings showed that articular cartilage content released upon injury, caused catabolic stress response of pChondro, but also increased cell proliferation and anabolic chondrogenic regulation of mAT-MSCs. This opposite pattern seems to be dependent on FGF2 regulation of TGF- $\beta R 3$ and FGFR3/FGFR1 ratio. The RNAScope $\AA$ technique showed a potential role of synovial membrane cells in early stages of cartilage injury and repair response. Furthermore, the main sites of simultaneous expression of TGF- $\beta$ R3 and FGFR3, are synovial membrane and inside the cartilage injury defect, suggesting a possible in situ localization of tissue resident MSCs.

\section{REFERENCES}

1. Vos T, Abajobir AA, Abate KH, Abbafati C, Abbas KM, Abd-Allah F, et al.; GBD 2016 Disease and Injury Incidence and Prevalence Collaborators. Global, regional, and national incidence, prevalence, and years lived with disability for 328 diseases and injuries for 195 countries, 19902016: a systematic analysis for the Global Burden of Disease Study 2016. Lancet. 2017;390(10100):1211-59.

2. Osteoarthritis Research Society International. Patients: understanding your osteoarthritis 
[Internet]. Mount Laurel: Osteoarthritis Research Society International; 2013 [cited 2019-02-07]. Available from: https://www.oarsi.org/patients

3. Kurtz S, Ong K, Lau E, Mowat F, Halpern M. Projections of primary and revision hip and knee arthroplasty in the United States from 2005 to 2030. J Bone Joint Surg Am. 2007;89(4):780-5.

4. McAlindon TE, Bannuru RR, Sullivan MC, Arden NK, Berenbaum F, Bierma-Zeinstra SM, Hawker GA, Henrotin Y, Hunter DJ, Kawaguchi H, Kwoh K, Lohmander S, Rannou F, Roos EM, Underwood M. et al. OARSI guidelines for the non-surgical management of knee osteoarthritis. Osteoarthritis Cartilage. 2014; 22(3): 363-388.

5. Pendleton A, Arden N, Dougados M, Doherty M, Bannwarth B, Bijlsma JW, et al. EULAR recommendations for the management of knee osteoarthritis: report of a task force of the Standing Committee for International Clinical Studies Including Therapeutic Trials (ESCISIT). Ann Rheum Dis. 2000;59(12):936-44.

6. de Girolamo L, Kon E, Filardo G, Marmotti AG, Soler F, Peretti GM, Vannini F, Madry H, Chubinskaya S. Regenerative approaches for the treatment of early OA. Knee Surgery, Sports Traumatology, Arthroscopy. 2016; 24(6): 1826-1835.

7. Freitag J, Bates D, Boyd R, Shah K, Barnard A, Huguenin L, Tenen A, Mesenchymal stem cell therapy in the treatment of osteoarthritis: Reparative pathways, safety and efficacy - A review. BMC Musculoskeletal Disorders. 2016; 17(1):230-243.

8. Peeters CM, Leijs MJ, Reijman M, van Osch GJ, Bos PK. Safety of intra-articular cell-therapy with culture-expanded stem cells in humans: a systematic literature review. Osteoarthritis Cartilage. 2013;21(10):1465-73.

9. Singer NG, Caplan Al. Mesenchymal stem cells: mechanisms of inflammation. Annu Rev Pathol. 2011;6(1):457-78.

10. McGonagle D, Baboolal TG, Jones E. Native joint-resident mesenchymal stem cells for cartilage repair in osteoarthritis. Nature Reviews Rheumatology. 2017; 13(12): 719-730.

11. Eseonu OI, De Bari C. Homing of mesenchymal stem cells: mechanistic or stochastic? Implications for targeted delivery in arthritis. Rheumatology (Oxford). 2015;54(2):210-8.

12. Awan B, Turkov D, Schumacher C, Jacobo A, McEnerney A, Ramsey A, Xu G, Park D, Kalomoiris S, Yao W, Jao LE, Allende ML, Lebrilla CB, Fierro FA. FGF2 Induces Migration of Human Bone Marrow Stromal Cells by Increasing Core Fucosylations on N-Glycans of Integrins. Stem Cell Reports. 2018; 11(2): 325-333.

13. Vincent, T. L. Targeting mechanotransduction pathways in osteoarthritis: A focus on the pericellular matrix. Current Opinion in Pharmacology. 2013; 13(3): 449-454.

14. Vincent TL, McLean CJ, Full LE, Peston D, Saklatvala J. FGF-2 is bound to perlecan in the pericellular matrix of articular cartilage, where it acts as a chondrocyte mechanotransducer. Osteoarthritis Cartilage. 2007; 15(7): 752-763.

15. Chia SL, Sawaji Y, Burleigh A, McLean C, Inglis J, Saklatvala J, Vincen T. Fibroblast growth factor 2 is an intrinsic chondroprotective agent that suppresses ADAMTS-5 and delays cartilage degradation in murine osteoarthritis. Arthritis and Rheumatism. 2009 60(7): 2019-2027.

16. Khan SN, Muhammad H, Scammahorn JJ, Dell'Accio F, Vincent TL. Fibroblast growth factor 2 promotes regeneration of cartilage by attracting mesenchymal stem cells to the site of cartilage injury. Osteoarthritis Cartilage. 2018; 26: S37.

17. Correa D, Somoza RA, Lin P, Greenberg S, Rom E, Duesler L, Welter JF, Yayon A, Caplan 
Al. Sequential exposure to fibroblast growth factors (FGF) 2, 9 and 18 enhances hMSC chondrogenic differentiation Osteoarthritis Cartilage. 2015; 23(3): 443-453.

18. Lopez-Casillas F, Wrana JL, Massague J. Betaglycan Presents Ligand to the TGFP Signaling Receptor. Cell vol. 1993; 73(7): 1435-1444.

19. Tang X, Muhammad H, McLean C, Miotla-Zarebska J, Fleming J, Didangelos A, Önnerfjord P, Leask A, Saklatvala J, Vincent TL. Connective tissue growth factor contributes to joint homeostasis and osteoarthritis severity by controlling the matrix sequestration and activation of latent TGF $\beta$. Annals of the Rheumatic Diseases. 2018; 77(9), 1372-1380.

20. Van Der KraanPM. The changing role of TGF $\beta$ in healthy, ageing and osteoarthritic joints. Nature Reviews Rheumatology. 2017; 13(3): 155-163.

21. MythreyeK,BlobeGC. The type III TGF- $\beta$ receptor regulates epithelial and cancer cell migration through $\beta$-arrestin2-mediated activation of Cdc42. Proceedings of the National Academy of Sciences of the United States of America. 2009; 106(20): 8221-8226.

22. National Centre for the Replacement, Refinement \& Reduction of Animals in Research. Euthanasia | NC3Rs; 2017 [cited 2020-05-05]. Available from: https://www.nc3rs.org.uk/euthanasia.

23. EltawilNM, De BariC, AchanP, PitzalisC,Dell'Accio F. A novel in vivo murine model of cartilage regeneration. Age and strain-dependent outcome after joint surface injury. Osteoarthr. Cartil. 2009, 17(6), 695-704.

24. Xing X, Li Z, Yu Z, Cheng G, Li D, Li Z. Effects of connective tissue growth factor (CTGF/CCN2) on condylar chondrocyte proliferation, migration, maturation, differentiation and signalling pathway. Biochemical and Biophysical Research Communications. 2018; 495(1): 1447-1453. 


\section{REFERÊNCIAS}

1. Osteoarthritis Research Society International. Patients: understanding your osteoarthritis [Internet]. Mount Laurel: Osteoarthritis Research Society International; 2013 [cited 2019 Feb 7]. Available from: https://www.oarsi.org/patients

2. Engel A. Osteoarthritis and body measurements. Vital Health Stat 11. 1968;11(29):1-37.

3. Vos T, Abajobir AA, Abate KH, Abbafati C, Abbas KM, Abd-Allah F, et al.; GBD 2016 Disease and Injury Incidence and Prevalence Collaborators. Global, regional, and national incidence, prevalence, and years lived with disability for 328 diseases and injuries for 195 countries, 19902016: a systematic analysis for the Global Burden of Disease Study 2016. Lancet. 2017;390(10100):1211-59.

4. Kurtz S, Ong K, Lau E, Mowat F, Halpern M. Projections of primary and revision hip and knee arthroplasty in the United States from 2005 to 2030. J Bone Joint Surg Am. 2007;89(4):780-5.

5. Kotlarz H, Gunnarsson CL, Fang H, Rizzo JA. Insurer and out-of-pocket costs of osteoarthritis in the US: evidence from national survey data. ArthritisRheum. 2009;60(12):354653.

6. Sociedade Brasileira de Reumatologia. Osteoartrite (artrose) [Internet]. São Paulo: Sociedade Brasileira de Reumatologia; 2019 [citado 2020 Jul 8]. Disponível em: https://www.reumatologia.org.br/doencas-reumaticas/osteoartrite-artrose/

7. Martel-Pelletier J, Barr AJ, Cicuttini FM, Conaghan PG, Cooper C, Goldring MB, et al. Osteoarthritis. Nat Rev Dis Primers. 2016;2(1):16072.

8. Zhang Y, Jordan JM. Epidemiology of osteoarthritis. Clin Geriatr Med. 2010;26(3):355-69.

9. Boissonneault A, Lynch JA, Wise BL, Segal NA, Gross KD, Murray DW, et al. Association of hip and pelvic geometry with tibiofemoral osteoarthritis: multicenter osteoarthritis study (MOST). Osteoarthritis Cartilage. 2014;22(8):1129-35.

10. Martin-Millan M, Castaneda S. Estrogens, osteoarthritis and inflammation. Joint Bone Spine. 2013;80(4):368-73.

11. Belluzzi E, El Hadi H, Granzotto M, Rossato M, Ramonda R, Macchi V, et al. Systemic and local adipose tissue in knee osteoarthritis. J Cell Physiol. 2017;232(8):1971-8.

12. Leong DJ, Sun HB. Osteoarthritis: why exercise? J. Exerc. Sports. Orthop. 2014;1(1):4.

13. Leong DJ, Sun HB. Mechanical loading: potential preventive and therapeutic strategy for osteoarthritis. J Am AcadOrthop Surg. 2014;22(7):465-6.

14. Sun HB. Mechanical loading, cartilage degradation, and arthritis. Ann N Y Acad Sci. 2010;1211(1):37-50.

15. Sophia Fox AJ, Bedi A, Rodeo SA. The basic science of articular cartilage: structure, composition, and function. Sports Health. 2009;1(6):461-8.

16. Akkiraju $\mathrm{H}$, Nohe $A$. Role of chondrocytes in cartilage formation, progression of osteoarthritis and cartilage regeneration. J Dev Biol. 2015;3(4):177-92.

17. Mathiessen A, Conaghan PG. Synovitis in osteoarthritis: current understanding with therapeutic implications. Arthritis Res Ther. 2017 2;19(1):18. 
18. Zhen G, Wen C, Jia X, Li Y, Crane JL, Mears SC, et al. Inhibition of TGF- $\beta$ signaling in mesenchymal stem cells of subchondral bone attenuates osteoarthritis. Nat Med.

2013;19(6):704-12.

19. Grynpas MD, Alpert B, Katz I, Lieberman I, Pritzker KP. Subchondral bone in osteoarthritis. Calcif Tissue Int. 1991;49(1):20-6.

20. Orr C, Vieira-Sousa E, Boyle DL, Buch MH, Buckley CD, Canete JD, et al. Synovial tissue research: a state-of-the-art review. Nat Rev Rheumatol. 2017;13(8):463-75.

21. Bar-Or D, Rael LT, Thomas GW, Brody EN. Inflammatory pathways in knee osteoarthritis: potential targets for treatment. CurrRheumatol Rev. 2015;11(1):50-8.

22. Sokolove J, Lepus CM. Role of inflammation in the pathogenesis of osteoarthritis: latest findings and interpretations. Ther Adv Musculoskelet Dis. 2013;5(2):77-94.

23. Heinemeier KM, Schjerling P, Heinemeier J, Moller MB, Krogsgaard MR, Grum-Schwensen $\mathrm{T}$, et al. Radiocarbon dating reveals minimal collagen turnover in both healthy and osteoarthritic human cartilage. Sci Transl Med. 2016;8(346):346ra90.

24. Mayo Clinic. Osteoarthritis: diagnosis and treatment [Internet]. Scottsdale: Mayo Clinic; 2020 [cited 2019 Feb 8]. Available from: https://www.mayoclinic.org/diseases-

conditions/osteoarthritis/diagnosis-treatment/drc-20351930

25. Hoch JM, Mattacola CG, Medina McKeon JM, Howard JS, Lattermann C. Serum cartilage oligomeric matrix protein (sCOMP) is elevated in patients with knee osteoarthritis: a systematic review and meta-analysis. Osteoarthritis Cartilage. 2011;19(12):1396-404.

26. Bassiouni HM, El-Deeb M, Kenawy N, Abdul-Azim E, Khairy M. Phonoarthrography, musculoskeletal ultrasonography, and biochemical biomarkers for the evaluation of knee cartilage in osteoarthritis. Mod Rheumatol. 2011;21(5):500-8.

27. Singh S, Kumar D, Sharma NR. Role of hyaluronic Acid in early diagnosis of knee osteoarthritis. J Clin Diagn Res. 2014;8(12):LC04-07.

28. Hochberg MC, Altman RD, April KT, Benkhalti M, Guyatt G, McGowan J, et al.; American College of Rheumatology. American College of Rheumatology 2012 recommendations for the use of nonpharmacologic and pharmacologic therapies in osteoarthritis of the hand, hip, and knee. Arthritis Care Res (Hoboken). 2012;64(4):465-74.

29. Pendleton A, Arden N, Dougados M, Doherty M, Bannwarth B, Bijlsma JW, et al. EULAR recommendations for the management of knee osteoarthritis: report of a task force of the Standing Committee for International Clinical Studies Including Therapeutic Trials (ESCISIT). Ann Rheum Dis. 2000;59(12):936-44.

30. Zhang W, Moskowitz RW, Nuki G, Abramson S, Altman RD, Arden N, et al. OARSI recommendations for the management of hip and knee osteoarthritis, Part II: OARSI evidencebased, expert consensus guidelines. Osteoarthritis Cartilage. 2008;16(2):137-62.

31. Wieland HA, Michaelis M, Kirschbaum BJ, Rudolphi KA. Osteoarthritis - an untreatable disease? Nat Rev Drug Discov. 2005;4(4):331-44.

32. Ran J, Yang X, Ren Z, Wang J, Dong H. Comparison of intra-articular hyaluronic acid and methylprednisolone for pain management in knee osteoarthritis: a meta-analysis of randomized controlled trials. Int J Surg. 2018;53:103-10.

33. Fernandes L, Hagen KB, Bijlsma JW, Andreassen O, Christensen P, Conaghan PG, et al.; European League Against Rheumatism (EULAR). EULAR recommendations for the non- 
pharmacological core management of hip and knee osteoarthritis. Ann RheumDis. 2013;72(7):1125-35.

34. Ondresik M, Azevedo Maia FR, da Silva Morais A, Gertrudes AC, Dias Bacelar AH, Correia $\mathrm{C}$, et al. Management of knee osteoarthritis. Current status and future trends. BiotechnolBioeng. 2017;114(4):717-39.

35. Mistry H, Connock M, Pink J, Shyangdan D, Clar C, Royle P, et al. Autologous chondrocyte implantation in the knee: systematic review and economic evaluation. Health Technol Assess. 2017;21(6):1-294.

36. Ogura T, Mosier BA, Bryant T, Minas T. A 20-year follow-up after first-generation autologous chondrocyte implantation. Am J Sports Med. 2017;45(12):2751-61.

37. Wang HL, Avila G. Platelet rich plasma: myth or reality? Eur J Dent. 2007;1(4):192-4.

38. Dai WL, Zhou AG, Zhang H, Zhang J. Efficacy of platelet-rich plasma in the treatment of knee osteoarthritis: a meta-analysis of randomized controlled trials. Arthroscopy. 2017;33(3):659-70.e1.

39. Zhang HF, Wang CG, Li H, Huang YT, Li ZJ. Intra-articular platelet-rich plasma versus hyaluronic acid in the treatment of knee osteoarthritis: a meta-analysis. Drug Des DevelTher. 2018;12:445-53.

40. BaghabanEslaminejad M, Malakooty Poor E. Mesenchymal stem cells as a potent cell source for articular cartilage regeneration. World J Stem Cells. 2014;6(3):344-54.

41. Peeters CM, Leijs MJ, Reijman M, van Osch GJ, Bos PK. Safety of intra-articular celltherapy with culture-expanded stem cells in humans: a systematic literature review. Osteoarthritis Cartilage. 2013;21(10):1465-73.

42. Wang W, Cao W. Treatment of osteoarthritis with mesenchymal stem cells. Sci China Life Sci. 2014;57(6):586-95.

43. Singer NG, Caplan Al. Mesenchymal stem cells: mechanisms of inflammation. Annu Rev Pathol. 2011;6(1):457-78.

44. Morikawa S, Mabuchi Y, Kubota Y, Nagai Y, Niibe K, Hiratsu E, et al. Prospective identification, isolation, and systemic transplantation of multipotent mesenchymal stem cells in murine bone marrow. J Exp Med. 2009;206(11):2483-96.

45. Xu L, Liu Y, Sun Y, Wang B, Xiong Y, Lin W, et al. Tissue source determines the differentiation potentials of mesenchymal stem cells: a comparative study of human mesenchymal stem cells from bone marrow and adipose tissue. Stem Cell Res Ther. 2017;8(1):275.

46. Dominici M, Le Blanc K, Mueller I, Slaper-Cortenbach I, Marini FC, Krause DS. et al. Minimal criteria for defining multipotent mesenchymal stromal cells. The International Society for Cellular Therapy position statement. Cytotherapy. 2006;8(4):315-7.

47. Keating A. Mesenchymal stromal cells: new directions. Cell Stem Cell. 2012;10(6):709-16.

48. Caplan Al. Mesenchymal stem cells: time to change the name! Stem Cells Transl Med. 2017;6(6):1445-51.

49. Caplan Al. All MSCs are pericytes? Cell Stem Cell. 2008;3(3):229-30. 
50. Crisan M, Yap S, Casteilla L, Chen CW, Corselli M, Park TS, et al. A perivascular origin for mesenchymal stem cells in multiple human organs. Cell Stem Cell. 2008;3(3):301-13.

51. Bianco P, Robey PG, Saggio I, Riminucci M. "Mesenchymal" stem cells in human bone marrow (skeletal stem cells): a critical discussion of their nature, identity, and significance in incurable skeletal disease. Hum Gene Ther. 2010;21(9):1057-66.

52. Bianco P, Robey PG, Simmons PJ. Mesenchymal stem cells: revisiting history, concepts, and assays. Cell Stem Cell. 2008;2(4):313-9.

53. Bianco P. Back to the future: moving beyond "mesenchymal stem cells". J Cell Biochem. 2011;112(7):1713-21.

54. Bianco P. Minireview: the stem cell next door: skeletal and hematopoietic stem cell "niches" in bone. Endocrinology. 2011;152(8):2957-62.

55. Lin P, Correa D, Kean TJ, Awadallah A, Dennis JE, Caplan AI. Serial transplantation and long-term engraftment of intra-arterially delivered clonally derived mesenchymal stem cells to injured bone marrow. Mol Ther. 2014;22(1):160-8.

56. Beyth S, Borovsky Z, Mevorach D, Liebergall M, Gazit Z, Aslan H, et al. Human mesenchymal stem cells alter antigen-presenting cell maturation and induce T-cell unresponsiveness. Blood. 2005;105(5):2214-9.

57. Wang Y, Chen X, Cao W, Shi Y. Plasticity of mesenchymal stem cells in immunomodulation: pathological and therapeutic implications. Nat Immunol. 2014;15(11):1009-16.

58. Qi K, Li N, Zhang Z, Melino G. Tissue regeneration: the crosstalk between mesenchymal stem cells and immune response. Cell Immunol. 2018;326:86-93.

59. de Windt TS, Hendriks JA, Zhao X, Vonk LA, Creemers LB, Dhert WJ, et al. Concise review: unraveling stem cell cocultures in regenerative medicine: which cell interactions steer cartilage regeneration and how? StemCellsTransl Med. 2014;3(6):723-33.

60. Manferdini C, Maumus M, Gabusi E, Piacentini A, Filardo G, Peyrafitte JA, et al. Adiposederived mesenchymal stem cells exert antiinflammatory effects on chondrocytes and synoviocytes from osteoarthritis patients through prostaglandin E2. Arthritis Rheum. 2013;65(5):1271-81.

61. Antonioli E, Piccinato CA, Nader HB, Cohen M, Goldberg AC, Ferretti M. Modulation of hyaluronan synthesis by the interaction between mesenchymal stem cells and osteoarthritic chondrocytes. Stem Cells Int. 2015;2015:640218.

62. Day AJ, de la Motte CA. Hyaluronan cross-linking: a protective mechanism in inflammation? Trends Immunol. 2005;26(12):637-43.

63. Meretoja VV, Dahlin RL, Kasper FK, Mikos AG. Enhanced chondrogenesis in co-cultures with articular chondrocytes and mesenchymal stem cells. Biomaterials. 2012;33(27):6362-9.

64. Ren J, Jin P, Sabatino M, Balakumaran A, Feng J, Kuznetsov SA, et al. Global transcriptome analysis of human bone marrow stromal cells (BMSC) reveals proliferative, mobile and interactive cells that produce abundant extracellular matrix proteins, some of which may affect BMSC potency. Cytotherapy. 2011;13(6):661-74.

65. Acharya C, Adesida A, Zajac P, Mumme M, Riesle J, Martin I, et al. Enhanced chondrocyte proliferation and mesenchymal stromal cells chondrogenesis in coculture pellets mediate improved cartilage formation. J Cell Physiol. 2012;227(1):88-97. 
66. Giovannini S, Diaz-Romero J, Aigner T, Heini P, Mainil-Varlet P, Nesic D. Micromass coculture of human articular chondrocytes and human bone marrow mesenchymal stem cells to investigate stable neocartilage tissue formation in vitro. Eur Cell Mater. 2010;20:245-59.

67. Black LL, Gaynor J, Adams C, Dhupa S, Sams AE, Taylor R, et al. Effect of intraarticular injection of autologous adipose-derived mesenchymal stem and regenerative cells on clinical signs of chronic osteoarthritis of the elbow joint in dogs. Vet Ther. 2008;9(3):192-200.

68. Murphy JM, Fink DJ, Hunziker EB, Barry FP. Stem cell therapy in a caprine model of osteoarthritis. Arthritis Rheum. 2003;48(12):3464-74.

69. Xing D, Kwong J, Yang Z, Hou Y, Zhang W, Ma B, et al. Intra-articular injection of mesenchymal stem cells in treating knee osteoarthritis: a systematic review of animal studies. Osteoarthritis Cartilage. 2018;26(4):445-61.

70. Kuyinu EL, Narayanan G, Nair LS, Laurencin CT. Animal models of osteoarthritis: classification, update, and measurement of outcomes. J Orthop Surg Res. 2016;11:19.

71. Xing D, Wang Q, Yang Z, Hou Y, Zhang W, Chen Y, et al. Mesenchymal stem cells injections for knee osteoarthritis: a systematic overview. Rheumatol Int. 2018;38(8):1399-411.

72. Schelbergen RF, van Dalen S, ter Huurne M, Roth J, Vogl T, Noel D, et al. Treatment efficacy of adipose-derived stem cells in experimental osteoarthritis is driven by high synovial activation and reflected by S100A8/A9 serum levels. Osteoarthritis Cartilage. 2014;22(8):115866.

73. Loeser RF, Olex AL, McNulty MA, Carlson CS, Callahan M, Ferguson C, et al. Disease progression and phasic changes in gene expression in a mouse model of osteoarthritis. PLoS One. 2013;8(1):e54633.

74. Huang H, Skelly JD, Ayers DC, Song J. Age-dependent changes in the articular cartilage and subchondral bone of C57BL/6 mice after surgical destabilization of medial meniscus. Sci Rep. 2017;7(1):42294.

75. lijima H, Isho T, Kuroki $\mathrm{H}$, Takahashi M, Aoyama T. Effectiveness of mesenchymal stem cells for treating patients with knee osteoarthritis: a meta-analysis toward the establishment of effective regenerative rehabilitation. NPJ Regen Med. 2018;3(1):15.

76. The Jackson Laboratory. Body weight information for C57BL/6J (000664) [Internet]. Bar Harbor: The Jackson Laboratory; 2020 [cited 2020 Jan 5]. Available

from: https://www.jax.org/jax-mice-and-services/strain-data-sheet-pages/body-weight-chart000664

77. Le Blanc K, Rasmusson I, Sundberg B, Gotherstrom C, Hassan M, Uzunel M, et al. Treatment of severe acute graft-versus-host disease with third party haploidentical mesenchymal stem cells. Lancet. 2004;363(9419):1439-41.

78. Le Blanc K, Frassoni F, Ball L, Locatelli F, Roelofs H, Lewis I, et al.; Developmental Committee of the European Group for Blood and Marrow Transplantation. Mesenchymal stem cells for treatment of steroid-resistant, severe, acute graft-versus-host disease: a phase II study. Lancet. 2008;371(9624):1579-86.

79. Gonzalez MA, Gonzalez-Rey E, Rico L, Buscher D, Delgado M. Treatment of experimental arthritis by inducing immune tolerance with human adipose-derived mesenchymal stem cells. Arthritis Rheum. 2009;60(4):1006-19. 
80. Rossetti RB, Massoco CO, Penna AC, Silva LC. An experimental study to compare inflammatory response due to liquid or gas joint distension in horses submitted to arthroscopy. Acta Cir Bras. 2012;27(12):848-54.

81. Lee K, Park N, Jung H, Rim YA, Nam Y, Lee J, et al. Mesenchymal stem cells ameliorate experimental arthritis via expression of interleukin-1 receptor antagonist. PLoS One. 2018;13(2):e0193086.

82. Fischer UM, Harting MT, Jimenez F, Monzon-Posadas WO, Xue H, Savitz SI, et al. Pulmonary passage is a major obstacle for intravenous stem cell delivery: the pulmonary firstpass effect. Stem Cells Dev. 2009;18(5):683-92.

83. Jiang X, Jiang X, Qu C, Chang P, Zhang C, Qu Y, et al. Intravenous delivery of adiposederived mesenchymal stromal cells attenuates acute radiation-induced lung injury in rats. Cytotherapy. 2015;17(5):560-70.

84. Tai WL, Dong ZX, Zhang DD, Wang DH. Therapeutic effect of intravenous bone marrowderived mesenchymal stem cell transplantation on early-stage LPS-induced acute lung injury in mice. Nan Fang Yi Ke Da XueXue Bao. 2012;32(3):283-90.

85. Li H, Fu X, Ouyang Y, Cai C, Wang J, Sun T. Adult bone-marrow-derived mesenchymal stem cells contribute to wound healing of skin appendages. Cell Tissue Res. 2006;326(3):72536.

86. Schenk S, Mal N, Finan A, Zhang M, Kiedrowski M, Popovic Z, et al. Monocyte chemotactic protein-3 is a myocardial mesenchymal stem cell homing factor. Stem Cells. 2007;25(1):24551.

87. Chen J, Li Y, Wang L, Zhang Z, Lu D, Lu M, et al. Therapeutic benefit of intravenous administration of bone marrow stromal cells after cerebral ischemia in rats. Stroke. 2001;32(4):1005-11.

88. Introna M, Rambaldi A. Mesenchymal stromal cells for prevention and treatment of graftversus-host disease: successes and hurdles. CurrOpin Organ Transplant. 2015;20(1):72-8.

89. Shehata AS, Al-Ghonemy NM, Ahmed SM, Mohamed SR. Effect of mesenchymal stem cells on induced skeletal muscle chemodenervation atrophy in adult male albino rats. Int $\mathrm{J}$ Biochem Cell Biol. 2017;85:135-48.

90. Xie C, Yang Z, Suo Y, Chen Q, Wei D, Weng X, et al. Systemically infused mesenchymal stem cells show different homing profiles in healthy and tumor mouse models. Stem Cells Transl Med. 2017;6(4):1120-31.

91. Burks S, Nguyen B, Kim S, Bresler M, Tebebi P, Frank J. Mesenchymal stem cell (MSC) homing to kidneys is suppressed by inhibiting interleukin 1- $\alpha$, tumor necrosis factor- $\alpha$, or cyclooxygenase-2 signaling. J Ther Ultrasound. 2015;3 S1:073.

92. Granero-Molto F, Weis JA, Miga MI, Landis B, Myers TJ, O'Rear L, et al. Regenerative effects of transplanted mesenchymal stem cells in fracture healing. Stem Cells.

2009;27(8):1887-98.

93. Eseonu OI, De Bari C. Homing of mesenchymal stem cells: mechanistic or stochastic? Implications for targeted delivery in arthritis. Rheumatology (Oxford). 2015;54(2):210-8.

94. Haywood L, Walsh DA. Vasculature of the normal and arthritic synovial joint. HistolHistopathol. 2001;16(1):277-84. 
95. Lennon DP, Haynesworth SE, Young RG, Dennis JE, Caplan AI. A chemically defined medium supports in vitro proliferation and maintains the osteochondral potential of rat marrowderived mesenchymal stem cells. Exp Cell Res. 1995;219(1):211-22.

96. Lennon DP, Edmison JM, Caplan Al. Cultivation of rat marrow-derived mesenchymal stem cells in reduced oxygen tension: effects on in vitro and in vivo osteochondrogenesis. $\mathrm{J}$ Cell Physiol. 2001;187(3):345-55.

97. Lennon DP, Caplan Al. Isolation of rat marrow-derived mesenchymal stem cells. Exp Hematol. 2006;34(11):1606-7.

98. Glasson SS, Blanchet TJ, Morris EA. The surgical destabilization of the medial meniscus (DMM) model of osteoarthritis in the 129/SvEv mouse. Osteoarthritis Cartilage. 2007;15(9):1061-9.

99. Sotocinal SG, Sorge RE, Zaloum A, Tuttle AH, Martin LJ, Wieskopf JS, et al. The rat grimace scale: a partially automated method for quantifying pain in the laboratory rat via facial expressions. Mol Pain. 2011;7:55.

100. Rodrigues MV, de Castro SO, de Albuquerque CZ, Mattaraia VG, Santoro ML. The gingival vein as a minimally traumatic site for multiple blood sampling in guinea pigs and hamsters. PLoS One. 2017;12(5):e0177967.

101. Glasson SS, Chambers MG, Van Den Berg WB, Little CB. The OARSI histopathology initiative - recommendations for histological assessments of osteoarthritis in the mouse. Osteoarthritis Cartilage. 2010;18 Suppl 3:S17-23.

102. Gerwin N, Bendele AM, Glasson S, Carlson CS. The OARSI histopathology initiative recommendations for histological assessments of osteoarthritis in the rat. Osteoarthritis Cartilage. 2010;18 Suppl 3:S24-34.

103. Chang YH, Auyang AG, Scholz JP, Nichols TR. Whole limb kinematics are preferentially conserved over individual joint kinematics after peripheral nerve injury. J Exp Biol. 2009;212(Pt 21):3511-21.

104. Piel MJ, Kroin JS, van Wijnen AJ, Kc R, Im HJ. Pain assessment in animal models of osteoarthritis. Gene. 2014;537(2):184-8.

105. Dias de Oliveira FB, Antoniolli E, Souza JG, Dias OF, Ferretti M. Mesenchymal stromal cells tracking and cytokines kinetics following intra-articular and intravenous transplantation. Osteoarthritis Cartilage. 2019;27:S203-4.

106. Dias de Oliveira FB, Souza JG, Furiama O, Ferretti M, Antoniolli E. Imaging and functional assessment of medial meniscus surgical destabilization animal model for osteoarthritis. Osteoarthritis Cartilage. 2018;26:S471-2.

107. Roos EM, Herzog W, Block JA, Bennell KL. Muscle weakness, afferent sensory dysfunction and exercise in knee osteoarthritis. Nat Rev Rheumatol. 2011;7(1):57-63.

108. Hunt MA, Charlton JM, Esculier JF. Osteoarthritis year in review 2019: mechanics. Osteoarthritis Cartilage. 2020;28(3):267-74.

109. Favre J, Jolles BM. Gait analysis of patients with knee osteoarthritis highlights a pathological mechanical pathway and provides a basis for therapeutic interventions. EFORT Open Rev. 2017;1(10):368-74. 
110. Tateuchi H. Gait- and postural-alignment-related prognostic factors for hip and knee osteoarthritis: toward the prevention of osteoarthritis progression. Phys Ther Res.

2019;22(1):31-7.

111. lijima H, Aoyama T, Tajino J, Ito A, Nagai M, Yamaguchi S, et al. Subchondral plate porosity colocalizes with the point of mechanical load during ambulation in a rat knee model of post-traumatic osteoarthritis. Osteoarthritis Cartilage. 2016;24(2):354-63.

112. Ruan MZ, Patel RM, Dawson BC, Jiang MM, Lee BH. Pain, motor and gait assessment of murine osteoarthritis in a cruciate ligament transection model. OsteoarthritisCartilage. 2013;21(9):1355-64.

113. Cunha JE, Barbosa GM, Castro PA, Luiz BL, Silva AC, Russo TL, et al. Knee osteoarthritis induces atrophy and neuromuscular junction remodeling in the quadriceps and tibialis anterior muscles of rats. Sci Rep. 2019;9(1):6366.

114. van der Poel C, Levinger P, Tonkin BA, Levinger I, Walsh NC. Impaired muscle function in a mouse surgical model of post-traumatic osteoarthritis. Osteoarthritis Cartilage.

2016;24(6):1047-53.

115. David MA, Smith MK, Pilachowski RN, White AT, Locke RC, Price C. Early, focal changes in cartilage cellularity and structure following surgically induced meniscal destabilization in the mouse. J Orthop Res. 2017;35(3):537-47.

116. Ernest TL, Kondrashov PE. The role of excessive body weight and meniscal instability in the progression of osteoarthritis in a rat model. Knee. 2018;25(6):1151-6.

117. Crema MD, Roemer FW, Felson DT, Englund M, Wang K, Jarraya M, et al. Factors associated with meniscal extrusion in knees with or at risk for osteoarthritis: the Multicenter Osteoarthritis study. Radiology. 2012;264(2):494-503.

118. MacMullan PA, McCarthy GM. The meniscus, calcification and osteoarthritis: a pathologic team. Arthritis Res Ther. 2010;12(3):116.

119. Menten $P$, Wuyts $A$, Van Damme J. Macrophage inflammatory protein-1. Cytokine Growth Factor Rev. 2002;13(6):455-81.

120. Mobasheri A., Bay-Jensen AC, van Spil WE, Larkin J, Levesque MC. Osteoarthritis year in review 2016: biomarkers (biochemical markers). 2017;25(2):199-208.

121. Zhao XY, Yang ZB, Zhang ZJ, Zhang ZQ, Kang Y, Huang GX, et al. CCL3 serves as a potential plasma biomarker in knee degeneration (osteoarthritis). Osteoarthritis Cartilage. 2015;23(8):1405-11.

122. Li M, Luo X, Lv X, Liu V, Zhao G, Zhang X, et al. In vivo human adipose-derived mesenchymal stem cell tracking after intra-articular delivery in a rat osteoarthritis model. Stem Cell Res Ther. 2016;7(1):160.

123. Shim G, Lee S, Han J, Kim G, Jin H, Miao W, et al. Pharmacokinetics and in vivo fate of intra-articularly transplanted human bone marrow-derived clonal mesenchymal stem cells. Stem Cells Dev. 2015;24(9):1124-32.

124. Ozeki N, Muneta T, Koga H, Nakagawa Y, Mizuno M, Tsuji K, et al. Not single but periodic injections of synovial mesenchymal stem cells maintain viable cells in knees and inhibit osteoarthritis progression in rats. Osteoarthritis Cartilage. 2016;24(6):1061-70. 
125. Satue M, Schuler C, Ginner N, Erben RG. Intra-articularly injected mesenchymal stem cells promote cartilage regeneration, but do not permanently engraft in distant organs. Nature. 2019;9:10153.

126. Fernandez-Pernas P, Rodríguez-Lesende I, de la Fuente A, Mateos J, Fuentes I, De Toro $\mathrm{J}$, et al. CD105+-mesenchymal stem cells migrate into osteoarthritis joint: an animal model. PLoS One. 2017;12(11):e0188072.

127. Olsen A, Johnson V, Webb T, Santangelo KS, Dow S, Duerr FM. Evaluation of intravenously delivered allogeneic mesenchymal stem cells for treatment of elbow osteoarthritis in dogs: a pilot study. VetCompOrthopTraumatol. 2019;32(3):173-81.

128. de Sousa EB, Casado PL, Moura Neto V, Duarte ME, Aguiar DP. Synovial fluid and synovial membrane mesenchymal stem cells: latest discoveries and therapeutic perspectives. Stem Cell Res Ther. 2014;5(5):112.

129. Boomsma RA, Geenen DL. Mesenchymal stem cells secrete multiple cytokines that promote angiogenesis and have contrasting effects on chemotaxis and apoptosis. PLoS One. 2012;7(4):e35685.

130. Chamberlain G, Fox J, Ashton B, Middleton J. Concise review: mesenchymal stem cells: their phenotype, differentiation capacity, immunological features, and potential for homing. Stem Cells. 2007;25(11):2739-49.

131. Bruno S, Camussi G. Role of mesenchymal stem cell-derived microvesicles in tissue repair. Pediatr Nephrol. 2013;28(12):2249-54.

132. Kim KH, Jo JH, Cho HJ, Park TS, Kim TM. Therapeutic potential of stem cell-derived extracellular vesicles in osteoarthritis: preclinical study findings. Lab Anim Res. 2020;36(1):10.

133. Matthay MA, Pati S, Lee JW. Concise Review: mesenchymal stem (stromal) cells: biology and preclinical evidence for therapeutic potential for organ dysfunction following trauma or Sepsis. Stem Cells. 2017;35(2):316-24.

134. Bari E, Ferrarotti I, Torre ML, Corsico AG, Perteghella S. Mesenchymal stem/stromal cell secretome for lung regeneration: the long way through "pharmaceuticalization" for the best formulation. J Control Release. 2019;309:11-24.

135. de Witte SF, Luk F, Sierra Parraga JM, Gargesha M, Merino A, Korevaar SS, et al. Immunomodulation by therapeutic mesenchymal stromal cells (MSC) is triggered through phagocytosis of MSC by monocytic cells. Stem Cells. 2018;36(4):602-15.

136. Weiss AR, Dahlke MH. Immunomodulation by mesenchymal stem cells (MSCs): mechanisms of action of living, apoptotic, and dead MSCs. Front Immunol. 2019;10:1191.

137. Carty F, Mahon BP, English K. The influence of macrophages on mesenchymal stromal cell therapy: passive or aggressive agents? Clin Exp Immunol. 2017;188(1):1-11.

138. Saraiva M, O'Garra A. The regulation of IL-10 production by immune cells. Nat Rev Immunol. 2010;10(3):170-81.

139. Nenasheva T, Nikolaev A, Diykanov D, Sukhanova A, Tcyganov E, Panteleev A, et al. The introduction of mesenchymal stromal cells induces different immunological responses in the lungs of healthy and M. tuberculosis infected mice. PLoS One. 2017;12(6):e0178983.

140. Zhong W, Tong Y, Li Y, Yuan J, Hu S, Hu T, et al. Mesenchymal stem cells in inflammatory microenvironment potently promote metastatic growth of cholangiocarcinoma via activating Akt/NF-kB signaling by paracrine CCL5. Oncotarget. 2017;8(43):73693-704. 
141. Appay V, Rowland-Jones SL. RANTES: a versatile and controversial chemokine. Trends Immunol. 2001;22(2):83-7.

142. Wang AT, Feng Y, Jia HH, Zhao M, Yu H. Application of mesenchymal stem cell therapy for the treatment of osteoarthritis of the knee: a concise review. World J Stem Cells. 2019;11(4):222-35.

143. Rafei M, Campeau PM, Aguilar-Mahecha A, Buchanan M, Williams P, Birman E, et al. Mesenchymal stromal cells ameliorate experimental autoimmune encephalomyelitis by inhibiting CD4 Th17 T cells in a CC chemokine ligand 2-dependent manner. J Immunol. 2009;182(10):5994-6002.

144. Kaplanski G. Interleukin-18: biological properties and role in disease pathogenesis. Immunol Rev. 2018;281(1):138-53.

145. Dinarello CA, Novick D, Kim S, Kaplanski G. Interleukin-18 and IL-18 binding protein. Front Immunol. 2013;4:289.

146. terHuurne M, Schelbergen R, Blattes R, Blom A, de Munter W, Grevers LC, et al. Antiinflammatory and chondroprotective effects of intraarticular injection of adipose-derived stem cells in experimental osteoarthritis. Arthritis Rheum. 2012;64(11):3604-13.

147. van Lent PL, Blom AB, Schelbergen RF, Sloetjes A, Lafeber FP, Lems WF, et al. Active involvement of alarmins S100A8 and S100A9 in the regulation of synovial activation and joint destruction during mouse and human osteoarthritis. Arthritis Rheum. 2012;64(5):1466-76.

148. Enomoto T, Akagi R, Ogawa Y, Yamaguchi S, Hoshi H, Sasaki T, et al. Timing of Intraarticular injection of synovial mesenchymal stem cells affects cartilage restoration in a partial thickness cartilage defect model in rats. Cartilage. 2020;11(1):122-9.

149. Wang Y, Yu D, Liu Z, Zhou F, Dai J, Wu B, et al. Exosomes from embryonic mesenchymal stem cells alleviate osteoarthritis through balancing synthesis and degradation of cartilage extracellular matrix. Stem Cell Res Ther. 2017;8(1):189.

150. Kuroda K, Kabata T, Hayashi K, Maeda T, Kajino Y, Iwai S, et al. The paracrine effect of adipose-derived stem cells inhibits osteoarthritis progression. BMC MusculoskeletDisord. 2015;16(1):236.

151. Toupet K, Maumus M, Peyrafitte JA, Bourin P, van Lent PL, Ferreira R, et al. Long-term detection of human adipose-derived mesenchymal stem cells after intraarticular injection in SCID mice. Arthritis Rheum. 2013;65(7):1786-94.

152. Li TS, Shi H, Wang L, Yan C. Effect of bone marrow mesenchymal stem cells on satellite cell proliferation and apoptosis in immobilization-induced muscle atrophy in rats. Med Sci Monit. 2016;22:4651-60.

153. Harrell CR, Markovic BS, Fellabaum C, Arsenijevic A, Volarevic V. Mesenchymal stem cellbased therapy of osteoarthritis: current knowledge and future perspectives. Biomed Pharmacother. 2019;109:2318-26.

154. Hoogduijn MJ, Roemeling-van Rhijn M, Engela AU, Korevaar SS, Mensah FK, Franquesa $M$, et al. Mesenchymal stem cells induce an inflammatory response after intravenous infusion. Stem Cells Dev. 2013;22(21):2825-35.

155. Fu Z, Liu P, Yang D, Wang F, Yuan L, Lin Z, et al. Interleukin-18-induced inflammatory responses in synoviocytes and chondrocytes from osteoarthritic patients. Int $\mathrm{J}$ Mol Med.

2012;30(4):805-10. 
156. Dai SM, Shan ZZ, Nishioka K, Yudoh K. Implication of interleukin 18 in production of matrix metalloproteinases in articular chondrocytes in arthritis: direct effect on chondrocytes may not be pivotal. Ann Rheum Dis. 2005;64(5):735-42.

157. Matsui K, Tsutsui H, Nakanishi K. Pathophysiological roles for IL-18 in inflammatory arthritis. Expert OpinTher Targets. 2003;7(6):701-24.

158. Wang Y, Xu D, Long L, Deng X, Tao R, Huang G. Correlation between plasma, synovial fluid and articular cartilage Interleukin-18 with radiographic severity in 33 patients with osteoarthritis of the knee. Clin Exp Med. 2014;14(3):297-304. 


\section{Abstract}

Introduction: Osteoarthritis is a progressive joint disease that mainly affects the articular cartilage, causing joint degeneration, pain and limitations on locomotor performance. Cell therapy, using mesenchymal stem cells, for cartilage regeneration has proved to be a viable alternative for treatment of osteoarthritis due to this therapy broad immunomodulatory action. However, the optimal route of cells delivery still needs to be identified (intra-articular or intravenous) to optimize cells transplantation. Purpose: To evaluate the administration routes for systemic (intravenous) or local (intra-articular) cell transplantation regarding their regenerative capacity for articular cartilage. Methods: This was an animal model (rat) study of osteoarthritis induced by medial meniscus destabilization surgery or by false surgery without injury. In vivo cell tracking was performed by bioluminescence, imaging flow cytometry, and confocal microscopy. The pro- and anti-inflammatory immunomodulation in serum and synovial wash samples were assessed by magnetic beads multiplex, and the regenerative capacity of transplanted cells were histologically evaluated. In addition, gait, functional performance and lower limb muscle balance were also evaluated. Results: After nine weeks, the animal model used did not change gait pattern, but reduced functional performance and developed muscle atrophy of quadriceps, gastrocnemius/soleus, and anterior tibialis. The transplanted cells remained viable on the operated knee up to one week after intra-articular transplant. Bioluminescence (8 hours; $N=1$ ) and positive events were detected by imaging flow cytometry (12 hours; $\mathrm{N}=2$ ) in the injured knee after the intravenous cell transplantation. The main cytokine changes occurred within 24 hours after the cell transplantation with increased expression of MCP-1 and RANTES for the intra-articular route, MIP-1 $\alpha$, and IL-10 for the intravenous route. This expression decreased after one week in both routes. The immune suppression of inflammatory cytokines occurred mainly for the intra-articular cell transplantation (MCP-1, RANTES, MIP-1a, IL-18) compared with placebo. This suppressive effect was also observed in synovial wash samples regarding concentration of IL-18 four weeks after intra-articular cellular transplant than that of placebo. Intravenous cellular treatment did not show the same immunosuppressive effect in the short term, and also showed a higher concentration of IL-1 $\beta$ one week later compared with intra-articular route. However, the treatment showed a reduction of RANTES in the long term over four and 12 weeks later 
compared with placebo transplantation. Intra-articular cell transplantation reduced muscle atrophy of anterior tibialis up to four weeks after the treatment compared with intravenous cell transplantation and intra-articular placebo. No histological changes of reduced articular cartilage degeneration were seen for any of the evaluated route or time after transplantation. Conclusion: The destabilization of medial meniscus in rats proved to be of slow developing and showed similar characteristics to human osteoarthritis. In addition, a single intra-articular or intravenous transplantation with mesenchymal stem cells was not enough to reduce the progression of osteoarthritis observed in the animal model, i.e., nine weeks after surgery regardless of the time studied. Despite the evidence of homing capacity for systemically transplanted cells and long-term effect over one inflammatory cytokine, our analyses showed cells with more evident immunosuppressive and tissue activity in locally transplanted cells for osteoarthritis treatment.

Keywords: Osteoarthritis/therapy; Osteoarthritis/surgery; Mesenchymal stem cell transplantation; Rats, Wistar 